\title{
Marathon running : functional changes in male and female volunteers during training and contest
}

Citation for published version (APA):

Janssen, G. M. E. (1988). Marathon running : functional changes in male and female volunteers during training and contest. [Doctoral Thesis, Maastricht University]. Rijksuniversiteit Limburg. https://doi.org/10.26481/dis.19880923gj

Document status and date:

Published: 01/01/1988

DOI:

10.26481/dis.19880923gj

Document Version:

Publisher's PDF, also known as Version of record

\section{Please check the document version of this publication:}

- A submitted manuscript is the version of the article upon submission and before peer-review. There can be important differences between the submitted version and the official published version of record.

People interested in the research are advised to contact the author for the final version of the publication, or visit the DOI to the publisher's website.

- The final author version and the galley proof are versions of the publication after peer review.

- The final published version features the final layout of the paper including the volume, issue and page numbers.

Link to publication

\footnotetext{
General rights rights.

- You may freely distribute the URL identifying the publication in the public portal. please follow below link for the End User Agreement:

www.umlib.nl/taverne-license

Take down policy

If you believe that this document breaches copyright please contact us at:

repository@maastrichtuniversity.nl

providing details and we will investigate your claim.
}

Copyright and moral rights for the publications made accessible in the public portal are retained by the authors and/or other copyright owners and it is a condition of accessing publications that users recognise and abide by the legal requirements associated with these

- Users may download and print one copy of any publication from the public portal for the purpose of private study or research.

- You may not further distribute the material or use it for any profit-making activity or commercial gain

If the publication is distributed under the terms of Article $25 \mathrm{fa}$ of the Dutch Copyright Act, indicated by the "Taverne" license above, 



\title{
Marathon running.
}

Functional changes in male and female volunteers during training and contests

\author{
PROEFSCHRIFT \\ ter verkrijging van de graad van doctor \\ aan de Rijksuniversiteit Limburg te Maastricht, \\ op gezag van de Rector Magnifficus, Prof. Dr. F.I.M. Bonke, \\ volgens het besluit van het College van Dekanen, \\ in het openbaar te verdedigen op \\ vrijdag, 23 september 1988 om 16.00 uur. \\ door \\ Gerard Maria Eugène Janssen \\ geboren te Hulsberg in 1948
}


Promotor:

Prof. Dr. F. ten Hoor

Beoordelingscommissie:

Dr. K. Hamulyak

Prof. Dr. H.C.G. Kemper

Prof. Dr. R.S. Reneman

Prof. Dr. H.A.J. Struyker Boudier

Dr. J.A. Vos

Het in dit proefschrift beschreven onderzoek werd mede mogelijk gemaakt door financiële steun van de Sportraad Limburg en giften van Medtronic, KNAU en ISL.

Druk: Drukkerij Alberts/Druko, Gulpen

I.S.B.N. $90-9002398-4$ 
MARATHON RUNNING.

FUNCTIONAL CHANGES IN MALE AND FEMALE VOLUNTEERS

DURING TRAINING AND CONTESTS

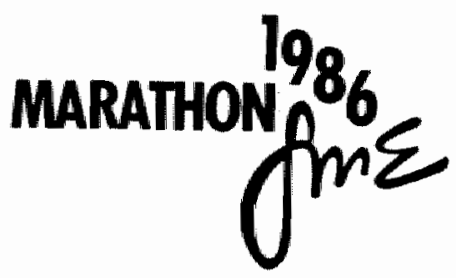





\section{CONTENTS}

page

Chapter 1 Generall Introduction 3

Sport and health in a general perspective 3

Introduction to the present study 6

Aim of the present investigation 8

Justification of the variables used 9

$\begin{array}{lr}\text { Design of the present investigation } & 12 \\ \text { References } & 13\end{array}$

Chapter 2 Materials, methods and procedures 20

Introduction 20

Procedure of enrollment 20

Outline of the study 21

Training procedure 22

Subjects 24

Drop outs 28

Test performances $\quad 29$

Muscle biopsies $\quad 29$

Contests 30

Variables measured 30

Statistical methods used in the marathon

study 36

References $\quad 39$

Chapter 3 Effects of endurance training and competition on exercise tests in relatively untrained people 41 References $\quad 54$

Chapter 4 Catabolic and anabolic changes associated with 56 endurance exercise

4.1 Plasma urea, creatinin, uric acid, albumin and total protein concentrations betore and after

15,25 and $42 \mathrm{~km}$ contests 56

References 67

4.2 Changes in basal plasma testosterone, cortisol and dehydroepiandrosterone sulphate in previously untrained males and females preparing for a marathon

References

Chapter 5 Blochemistry and morphology of skeletal muscle 84

5.1 The effect of training and 15, 25 and $42 \mathrm{~km}$ contests on the skeletal muscle content of adenine and guanine nucleotides, creatine phosphate and glycogen 84 References 95

5.2 Histological changes assoclated with long
distance training and running $\begin{array}{lr}\text { distance training and running } & 97 \\ \text { References } & 103\end{array}$ 
5.3 Activity of plasma creatin phoshokinase,

page

L-aspartate aminotransferase, L-alanine amino-

transferase and the quantification of skeletal

muscle damage associated with 15,25 and 42

$\mathrm{km}$ contests and physical exercise tests

104

References

116

Chapter 6 Hematological changes associated with training for a marathon

6.1 The effect of training on red blood cell parameters and plasma ferritin: a transverse and a longitudinal approach

References

6.2 White cell system changes associated with a training period of $18-20$ months: a transverse and a longitudinal approach References

6.3 Platelet system changes associated with a training period of 18-20 months: a transverse and a longitudinal approach References

Chapter 7 General discussion

References

Samenvatting

Curriculum vitae

Dankwoord 
Hel generaliseren van de daden van verdwaa(s)lde lo(o)p(st)ers leidt te vaak tot de conclusie dat hardlopen ongezond is, terwijl de beoordeling van prestaties en de waarde van het hardlopen van een marathon te vaak gebeurt door niet-lopers.

Ter nagedachtenis aan: Pap

Voor: Mam en alle helpers 



\section{Chapter 1 General Introduction}

\section{Sport and health in a general perspective}

Physical recreation has become an important cultural phenomenon in our society, even more so since the amount of leisure has increased. An active lifestyle can be regarded as positive since physical activity is a pleasant way to spend spare time and in general it will promote health. Therefore health motives also play an important role for active people. In The Netherlands practising sport has been growing during the last 10 years (106); the percentage of active people increased from 62 in 1978, to 73 in $1979-1983$ and to $75 \%$ of the total population in 1984 . However, as far as the organized sport is concerned it seems that after an initial increase it has become stabilized now. According to Manders and Kropman $75 \%$ of the population (age 15-75 years) could be classified as physically active people. of these, $34 \%$ were nonorganized, $6 \%$ were exclusively organized and $35 \%$ were active in organized as well as non-organized sports (71).

Among various types of physical activity especlally running has become popular. In 1978 the running rage crossed the Atlantic and conquered Europe. In 1985 an inquiry was held in The Netherlands (Inter/view b.v.) which showed that the number of runners that ran once a week amounted to 2.4 millions or $15.0 \%$ of the total population (48). Five \% of the runners ran five times a week and another $5 \%$ once a week. The popularization of running resulted in a large increase of people running long distances and the marathon (distance $42.195 \mathrm{~km}$ ). Figures of the Dutch Athletic Association ( $\mathrm{KNAU}$; membership between 50000-60000) show an increase in the number of marathon runners (Table 1.1).

This development is a favourable one as there are clear indications that regular physical exercise may play a role in the prevention of cardiovascular diseases (85). Physical activity may have a direct effect on the coronary circulation (66) or an indirect effect, for instance via a decrease in excessive weight (fat mass) (66). However, running may also have adverse effects, such as the increasing number of sport injuries and a certain number of people who dle during or shortly after sporting $(20,24,30,32,38,40,44)$. 
Table 1.1 Number of partlclpants in marathons held in the Netherlands and the number of partlclpants running the marathon faster than $2.5,3$ and $3.5 \mathrm{~h}$ during the years 1976-1986

\begin{tabular}{|c|c|c|c|c|c|c|c|}
\hline \multirow[b]{2}{*}{ year } & \multirow[b]{2}{*}{ m. o. } & \multicolumn{3}{|c|}{ Males } & \multicolumn{3}{|c|}{ Fenales } \\
\hline & & tatal & r.t.e3h & $r \cdot t .<2.5 h$ & total & $r . t .<3.5 \mathrm{~h}$ & $r \cdot t \cdot<3 h$ \\
\hline 1976 & 5 & 450 & 161 & 12 & 6 & 4 & 1 \\
\hline 1977 & 5 & 500 & 207 & 15 & 11 & 1 & - \\
\hline 1978 & 7 & 600 & 224 & 28 & 12 & 4 & 1 \\
\hline 1979 & 8 & 750 & 300 & 30 & 19 & 12 & 1 \\
\hline 1980 & 7 & 1500 & 354 & 29 & 23 & 15 & 1 \\
\hline 1981 & 7 & 2800 & 440 & 32 & 40 & 20 & 6 \\
\hline 1982 & 11 & 3600 & 810 & 59 & 63 & 30 & 11 \\
\hline 1983 & 11 & 4500 & 1128 & 64 & 72 & 34 & 15 \\
\hline 1984 & 20 & 6300 & $1: 200$ & 67 & 88 & 44 & 13 \\
\hline 1985 & 20 & 7000 & 1230 & 62 & 120 & 61 & 21 \\
\hline 1986 & 23 & 8500 & 2100 & 150 & 287 & 80 & 25 \\
\hline
\end{tabular}

The data of $<2.5 \mathrm{~h}$ and $<3 \mathrm{~h}$ are not included $\| \mathrm{n}<3 \mathrm{~h}$ and $<3.5 \mathrm{~h}$, respectively

m.o.: number of marathons organlzed

r.t.: running time

The number of deaths during or shortly after physical activity (sudden death) is evidently a negative aspect although the occurrence of sudden death, related to physical activity is low. Thompson found that in a period of 6 years, from 1975 till 1980, a total of 12 men died during jogging in the state of Rhode Island (105). The cause of death in 111 cases was coronary heart disease (CHD). The prevalence of running in the Rhode Island population was determined by making use of a telephone survey. Among men aged 30 to 64 years $7.4 \pm 2.6 \%$ (mean \pm s.d. of the estimate) reported to run at least twice a week. The occurrence of death during running was one in every 7620 active people or one per 396000 man-hours running. This rate was 7 times the estimated death rate from $\mathrm{CHD}$ during the more sedentary activities in Rhode Island and suggests that exercise contributes to sudden death in susceptible persons. Franke calculated that the percentage of deaths was $0.1 \%-0.3 \%$ of the registrated injuries of sport and that death in sport was rarely caused primarily through physical exercise (32). Dolman found that during the years 1978,1979 , and 1980 the number of deaths associated with physical exertion in the Netherlands was 28, 68 and 89, respectively (24). Knulst calculated that there is one death per 45000 sporting people or per $7000000 \mathrm{~h}$ of physical exercise (60). Results of Haskell show one death per $887000 \mathrm{~h}$ of physical exercise (40).

As to the causes of death in connection with exercise one may conclude that the majority is due to previously known and unknown heart diseases $(24,40,80)$. Haskell estimated that $0.4 \%$ of all 
cardiovascular deaths in Finland between 1969 and 1978 were associated with physical activity (40). In the years 1978-1980 the total amount of sudden deaths in The Netherlands due to cardiovascular diseases as primary factor but irrespective of physical activity is summarized in Table 1.2 (11).

Table 1.2 The incidence of sudden death due to cardlovascular diseases in The Netherlands dur ling the years 1978-1980

\begin{tabular}{|c|c|c|c|c|c|c|}
\hline Cause of Death & & & & & & \\
\hline & male & fernale & male & fenale & male & fema le \\
\hline heart dilsease & 2771 & 510 & 2655 & 528 & 2519 & 515 \\
\hline cerebrovasc. dis. & 429 & 391 & 444 & 358 & 471 & 362 \\
\hline nypertens lon & 53 & 35 & 45 & 34 & 46 & 23 \\
\hline Ischem. heart dis. & 3064 & 573 & 2979 & 591 & 2861 & 573 \\
\hline mors sublta e.c. 1 . & 137 & 48 & 136 & 42 & 138 & 41 \\
\hline TOTAL & 6454 & $15 \overline{57}$ & 6259 & 1553 & 6035 & 1514 \\
\hline
\end{tabular}

Comparing the data of Dolman with the total amount of deaths in Table 1.2 one may be tempted to conclude that the number of deaths associated with physical activity is increasing whereas the total number of deaths due to CHD is decreasing. However, the decrease in the number of people with heart disease is most probably due to improved medical treatment and extensive preventive programmes. Prevention is partly based on intervention to risk-tactors by changes in life style, nutrition and increased physical activity. Although physical activity may have a preventive effect in $\mathrm{CHD}$, it has become clear that physical activity is not a safeguard against cardiovascular diseases, as the active people also bellong to our society with all its risk-factors.

It cannot be concluded that a low incidence of sudden death in physically active people can solely be attributed to physical activity $(28,100)$.

The incidence of sport injuries which is another negative effect of physical activities may vary from 1-50\% largely depending on the definition of sport injury, the type of sport and registration of injuries $(7,38,62,69,107)$. Groh reported an incidence of sport injuries of $15 \%$, being the number of new injuries in a certain period in relation to active people at the beginning of the period (38). Steinbruch estimated that in Germany $10-15 \%$ of all accidents were caused by sport activities while Williams estimated that in England $5 \%$ of the treated injuries seen by the Accident \& Emergency departments were sport injuries (107). In The Netherlands the incidence of sport injuries was $21 \%$ of all injuries in private circumstances (90). From the continuous "Personal Accidents Registration-System" it appeared that of the 32276 accidents, treated at the Accident \& Emergency departments, $28.6 \%$ were associated with sport (68). Among long distance runners the incidence varied from 5 to $15 \%$. Devereaux calculated that $5.6 \%$ of 
the registrated sport injuries during the years 1981-1982 was associated with long distance running (20). Kowal's study (61) shows exceptionall figures. In this study on military training the percentage of injuries was about $54 \% ; 30 \%$ of the injured persons had to abstain from training. Early training "overuse syndrome" accounted for $42 \%$ of the registered injuries. It is possible that the very high incidence of injuries among these athletes was due to the workload: the military training was done together with the additional running exercise for 8 weeks.

Segesser (97) considers overload lesions due to sport as the consequence of an imbalance between physical stress and physical stress tolerance. Various factors may contribute to this imbalance. According to the literature the occurrence of overstrain injuries varles greatly because active people and athletes do not report their injuries as long as they do not trouble them in everyday life. In running, the locomotor system is most frequently affected at the knees and the Achilles tendon. In Table 1.3 these injuries are summarized from literature $(45,104)$.

Table 1.3 Overstraln Injurles in runners

\begin{tabular}{|c|c|c|c|c|}
\hline & $\begin{array}{c}\text { Peltokal } \| \text { \|o } \\
(1977) \\
*\end{array}$ & $\begin{array}{l}\text { James } \\
(1978) \\
(n=232)\end{array}$ & $\begin{array}{c}\text { Brody } \\
(1980) \\
(n=3000)\end{array}$ & $\begin{array}{c}\text { Temple } \\
(1983) \\
(n=1700)\end{array}$ \\
\hline Knee & 17.9 & 29 & 30 & 24.8 \\
\hline Shln (Shlnsp Ints) & 10.6 & 13 & 15 & 10.3 \\
\hline Ach ll les tendon & 14.0 & 11 & 20 & 17.5 \\
\hline Foot arch & 6.9 & 7 & 10 & 8.1 \\
\hline Stress fractures & 5.9 & $\theta$ & 15 & - \\
\hline Hamstr Ing & - & - & - & 5.4 \\
\hline HIp & --- & -- & - & 3.5 \\
\hline Other & 44.7 & 34 & 10 & 30.4 \\
\hline
\end{tabular}

Data in \% of total amount of injuries mentloned by the authors In the or IgInal presentat Ion absolute numbers were not presented (*)

\section{Introduction to the present study}

\section{Training and recovery}

James (49) and Von Hille (44) suggest that about $50 \%$ of physical overstress injuries are related to an inadequate way of training while the other $50 \%$ are due to anatomic deformations and bad running equipment. Haycock suggests that the skill of the coaches and trainers is related to the number of injuries (41). Depending on the quality and coordination of the locomotor system an athlete will be more or less liable to injuries. There are even active people who want to practice a sport which does not suit their physical abilities. The physical qualities of active people (internal factors) have to be considered in relation to the training load, climatic 
factors, field condition, clothing and shoes (external factors). If the internal factors do not balance the external factors there is an increased chance that the athlete gets overstressed and injured. One can therefore postulate that during and after training sport injuries and part of the physical overstress injuries develop firstly due to insufficient knowledge of the physiology of training, secondly on account of anatomical restrictions and thirdly because of bad equipment. Besides, it appears that $96 \%$ of the participants run a marathon mainly for the thrill of it, $78 \%$ for self-conviction, $62 \%$ for general health and only $33 \%$ just for fun (30). Being too eager to train can lead to injuries, especially since people tend to overestimate their tallent and capacity. To run a marathon an appropriate and thorough training is necessary. A lot of active people want to extend the limit of their physicall capacities which means that they try to run faster or to cover longer distances. In order to achieve this load there is always the danger that insufficient time is spent on a proper build-up of the training schedule. This may lead to structural physical overstress combined with a possible increase of injurles (32).

During physical exertion the body transforms chemical energy into mechanical energy. The last link in the chain of reactions is contraction and relaxation of the skeletal muscles. For continuous movement a stream of chemical energy is necessary. Carbohydrates, lipids and possibly proteins serve as energy substrates in this chain of chemical reactions. Which substrate is being used is dependent on the intensity and the duration of the exercise. The energy sources in the cell are not exclusively for the mechanical labour but for other cell functions as well. Besides it is necessary for the presence of energy substrates in the cell that the supply of energy substrates has been guaranteed. This entire process takes place through a chain of chemicall reactions.

The object of training is to elicit adaptations in the body in order to bring body functions at a higher llevel to achieve better results. During the actual training the structural and biochemical constitution of cells, organs and organ systems are challenged, leading to an increased catabolism.

In the recovery period the disturbed cells or organ systems try to regain homeostasis and anticipate to another disturbance of homeostasis by an over-adaptation. In the recovery phase anabolic processes have to be switched on. Kuoppasalmi and Adlercreutz (64) suggest that a changed balance between hormones with a catabolic and anabolic effect may influence the adaptive processes which occur during and after physlcal exercise. It has for instance been shown that a decreased production of cortisol is important for the onset of anabolic processes $(58,96,108)$. It is conceivable that exercise at a time when hormonal balance is deranged, may further deteriorate the hormonal system, thus compromizing recovery. Continuation of the physical exercise may lead to more fatigue and since the athlete may interpret increased fatiguabllity as 
insufficient training this will ensue a vicious circle with increased stress. The neuro-endocrine system may alternately be activated and inhibited (108) and finally become exhausted. During recovery overshoot compensations develop, so that the starting point for the physical activity is better than before. In a normal training situation there has to be a proper balance between the disturbed homeostasis and recovery, leading to an increase of individual physical stress tolerance. To attain this situation the training stimulus needs to become stronger and stronger in volume and intensity in order to increase the functional capacity $(3,31,47,67,73,74)$.

When recovery time is too short for restoration of homeostasis, deterioration of cellular function will ensue and premature fatigue may occur. In this case there will not be an increase but rather a decrease of the physical stress tolerance and performance.

If there is a prolonged imbalance between physical stress and physical stress tolerance over a longer period of time, a situation develops which is called overtraining syndrome. In an overtraining syndrome or staleness an imbalance in the autonomic nervous and endocrine system is found, which originates from a dysfunction at hypothalamic level (4). There are two different types of overtraining, the sympathetic form and the para-sympathetic form. The first type is characterized by tiredness, loss of appetite, sleep disorder, and irritability. The second type, mostly following the first one, is characterized by a low resting pulse rate, low exercise blood lactate levels and hypoglycemia early in exercise $(15,59)$.

Because a contest can be considered as an acute overload so that an imbalance occurs between physical stress and physical stress tolerance it is possible to use contests, especially a marathon, as a model to study the changes in variables of the various organ systems and the influence on performance as measure for delay of recovery.

\section{Aim of the present investigation}

Although many studies have been done concerning the impact of training and competition on various body functions, the results have usually been obtained under strongly varying and non-standardized conditions making them mutually incomparable and difficult to extrapolate.

The aim of the present investigation was to study a number of changes which take place in the organism during training and contests performed under standardized conditions, in order to get insight into adaptation to and consequences of training, and into recovery processes which take place after endurance exercise of increasing volume.

Therefore 114 untrained volunteers were trained in a standardized way. After appropriate training periods they took part in contests of $15 \mathrm{~km}$, $25 \mathrm{~km}$ and $42 \mathrm{~km}$, respectively (Fig. 2.1).

Before and after each contest physical exercise tests were performed. The results of the consecutive tests, performed during the recovery periods following each contest, were compared to the pre-contest values in order to study recovery (Fig. 2.2). 
In order to recognize a possible disturbed balance between physical stress and physical stress tolerance on a morphological, biochemical and hormonal level, the following variables classified into four categories were studied:

- Cardio-respiratory system and performance

- Catabolic and anabolic changes associated with endurance exercise

- Biochemistry and morphology of skeletal muscle tissue

- Hematology

\section{Justification of the variables used}

\section{Cardio-respiratory system and performance}

The cardio-respiratory system of a well trained person will not easily become overstressed or ensue impaired function during long lasting contests because cardiac function is never challenged to the upper functional limit. However, it was demonstrated that the aerobic power was less one week after the marathon in comparison with the aerobic power one week before the marathon (82). Others showed that the test performance did not decrease after a $30 \mathrm{~km}$ race but that it did after a marathon $(51,52,53)$. This suggests that cardiac function may be affected by endurance running.

In the present investigation cardio-respiratory system and performance were studied during physical exercise tests before and after 15,25 and $42 \mathrm{~km}$ contests. Training adaptation was studied by comparing the variables measured during the physicall exercise tests before each contest $(95,101)$. Due to similar training schedules, contests and physical exercise tests before and after the contests it was possible to study differences in recuperation after exertion.

Maximal speed, blood lactate concentration and heart frequency were used as parameters of the functional capacity of cardio-respiratory system and performance. In addition the variables mentioned were related to results of biochemical and hormonal variables.

Catabolic and anabolic changes associated with endurance exercise

The determination of blood plasma concentrations of urea, creatinin, uric acid, albumin, total protelln and hormones (cortisol, testosterone and dehydroepiandrosteronesulphate $=$ DHEAS) gives an impression of catabolic and anabolic processes before and after the contests $(1,2,8,12,19,23,25,65,76,84,88,91,116)$. As there is a reduced blood flow in the splanchnic area, liver and kidneys during physical exercise, the time course of the blood concentration of creatinin after a contest may yield information about the kidney function. The blood concentrations of urea and uric acid and the enzyme alanine aminotransferase (Alat) may be assessed as parameters of the liver function $(70,93)$.

The relationship between normalization of plasma levels of muscle enzymes and intermediate metabolites after a contest on the one hand and the recovery of performance on the other hand is far from clear. There are indications that certain hormones such as testo- 
sterone, cortisol and DHEAS play a role in recovery processes, mechanisms of adaptation and homeostasis $(26,29,39,42,50,89)$. In order to get insight whether there exists a relationship between metabolites, enzyme and hormone concentrations in blood on the one hand and performance on the other hand, we determined blood concentrations of urea, creatinin, uric acid, cortisol, testosterone and DHEAS before and after contests during the test period.

\section{Biochemistry and morphology of skeletal muscle tissue}

Biochemistry and morphology of skeletal muscle tissue were studied in order to relate the supposed damage of muscles during long lasting physical exercise (marathon) to the leakage of the specific muscle enzymes creatine phosphokinase (CK) and L-aspartate aminotransferase (Asat) and the energy status of skeletal muscle.

\section{+ Biochemistry of muscles}

Empirically it appears that a continuation of intensive training after running a marathon often leads to general malaise and injuries. It is not clear which mechanisms are responsible for these problems. Although there are several authors who indicate that this phenomenon is due to substrate depletion, it seems to be an oversimplification of the problem $(13,14,16,25,37)$. This already becomes clear from the work of costill et al. in which after a number of high-pace endurance runs no normal recovery of the musclle glycogen was noticed in spite of a carbohydrate rich diet $(16,37)$. They showed that the decrease of performance does not run parallel to the decrease of glycogen resynthesis. For this reason the question to what extent the resynthesis of glycogen in muscle depends on the extent of the average depletion or on depletion in separate muscle fibers is not clear. Of course this is only one point of view in relation with performance decrease after exhaustive physical exercise.

As to the situation of energy rich phosphate compounds and related substances in muscular cells after long lasting physical exercise only few data are avaliable $(5,54,56,57,75,78,79,98,102)$.

In the present investigation the influence of an acute physical long lasting overstress -mainly at aeroblc level- on glycogen, energy rich phosphate compounds and other muscle metabolites was studied immediately and one week after the contests. In addition the intluence of gender and training on glycogen, energy rich phosphate compounds and other muscle metabolites has been investigated.

\footnotetext{
+ Histology $y_{1}$ Histochemistry and Electronmicroscopy in skelletal musclle tissue

It has been shown that after running a marathon sections of muscle fibre of skeletal muscles completely disappear and that membrane and myofibrillar damage occurs. The damage is often accompaniled by an inflammatory response $(63,109)$. Also high blood concentrations of muscle enzymes are found particularly after a marathon.
} 
Furthermore it appears that when a maximal exercise test is done 4-6 days after a marathon a renewed leakage of muscle enzymes develops $(51,52)$.

One of the objectives of the present investigation was to follow a number of male and female runners who undertook a standardized trailining schedule in order to run contests of $15 \mathrm{~km}, 25 \mathrm{~km}$ and a marathon, and to test the hypothesis concerning the positive relationship between damage of muscle fibers and leakage of muscle enzymes.

+ Leakage of muscle enzymes into blood after long lasting physical exercise

The reason for leakage of muscle enzymes is not known, although the activity of muscle enzymes in blood increases due to chemical, mechanical and thermic stress $(51,52,55,117)$. In general the degree of leakage of muscle enzymes is accepted as a measure for damage of the skeletal muscle $(81,83,92,99)$. The enzymes which are considered to be representative for the damaged skeletal muscle are: creatine kinase (CK), aspartate aminotransferase (Asat), alanine aminotransferase (Alat), malate dehydrogenase (MDH) and lactate dehydrogenase (LDH). The interpretation of activity changes of enzymes as a measure for muscle damage is difficult for the following reasons.

- Enzymes and their isoenzymes are present in organs other than skeletal muscle.

- Changes of concentration may be caused by various circumstances.

- There are differences in half-life time $\left(t_{w_{2}}\right)$ of various enzymes.

- There are differences in the standardization of determination methods.

The aim of the present study was to make a quantitative approach to the relationship between muscle damage and enzyme release using the model of Willems et al. $(43,111,112)$. The activity and the quantity of the muscle enzymes have been studied after 15, 25, 42 km contests and exercise tests after each contest, respectively. Another aspect which has been studied is whether a uniform training method has any influence on the degree of leakage of the speclfic muscle enzymes.

\section{Hematology}

The hematological aspects were primarily studlled in order to protect the volunteers during the perlod of training from sport anemia $(10,17,21,27,46,103,110,113,115,118)$. Nevertheless the changes in the red and the white cells, the thrombocytes, red cell and trombocytic indices, and the ferritin concentration of the blood were studied transversely and longitudinally.

It is known that a lot of endurance athletes develop a lower hemoglobin and ferritin content of blood during training in comparison to untrained people. This is often seen as a cause for a decrease in performance $(10,27,113,115,118)$. We therefore regularly determined hemoglobin and ferritin content of blood in our volunteers. 
From the white cell system it is known that an increased blood flow induced by physical exercise increases especially granulocyte count for more than $100 \%$ in a very short time and that the athletes are more sensible to infection $(34,35,36,77,86,87)$. The increase in number of leukocytes, having a tw of $6-7 \mathrm{~h}$ in the circulation, can occur very rapidly by a shift between the circulating pool (CGP) and the pool between blood and bone marrow (MGP) (114). Besides, it is possible that after longer lasting physical stress leukocytes are released from bone marrow by cortisol. Granulocytosis and monocytosis depend not only on exercise but also on cortisol and adrenaline concentration $(6,114)$. The thrombocyte count remains relatively constant in normal healthy people for months and even for years.(114). It has been documented that after physical exercise the number of thrombocytes increases by a release from the spleen. There are still other influences of physical exercise, e.g. on the sensitivity of the platelets $(18,22,33,35,36,94)$. We studied the change of number and volume of platelets, platelet distribution width and plateletcrit during the training period and after the various contests.

\section{Design of the present investigation}

Although a lot of data are available on physical stress tolerance after contests and maximal exercise tests, most of these data have been obtained in different types of sports and/or in different circumstances. It is therefore difficult to compare results of these studles, because training experience, training status, training method and intensity and time of training in preparation for a contest are often not well documented or not comparable to those of other studies. Besides, in most studiles the period of testing before and after a contest was not standardized (72).

In order to consider the balance between physical stress and physical stress tolerance due to physical exercise, a longltudinal study under strictly standardized conditions is desirable.

We therefore started a 20 months lasting study with untrained people, a standardized training method and a standardized test protocol around contests with increasing physical stress. The aim of the contests was to linduce acute physically overstressed situations with muscle damage, lincrease of plasma activity of muscle enzymes, and changes in hormone levels and metabolites in blood. Because the volunteers trained for 1820 months to run contests over 15,25 , and $42 \mathrm{~km}$, It was also possible to study the adaptation to training by comparing the results of the varlous measured parameters, obtained during the week before the contest. 
References

1 Aakvaag A., Opstad P.K.: Hormonal responses to prolonged physical strain, effect of caloric deficiency and sleep deprivation, in Fotherby K., Pal S.B. (eds): Exercise Endocrinology. W. de Gruyter, Berlin, pp 25-46,1985.

2 Allenberg K., Holinquist N.: Effect of exercise and testosterone and the active form of glycogen synthase in human skeletal muscle. International Series on Sport Sciences vol. 13 in H.G. Knuttgen, J.A. Vogel and J. Poortmans (eds): Biochemistry of Exerclise, 1982.

3 Autorenkollektiv unter der Leitung von Karl-Heinz Bauersfeld und Gerd Schroeter: Grundlagen der Leichtathletlk. Sportverlag Berlin,1979.

4 Barron G.L. Noakes T.D., Levy W., Smith C., Millar R.P.: Hypothalamic dysfunction in overtrained athletes. J CIIn Endocr Metab 60(4):803-806,1985.

5 Belcastro A.N., Campbell C.J., Bonen A., Kirby R.L.: Adaptation of human skeletal muscle myofibril ATPase activity to power training. Aust J Sp Med 13(4):93-97,1981.

6 Bishop, C.R., Athens J.W., Boggs D.R., Warner H.R.: Leukokinetic studles XIII. A non-steady state kinetic evaluation of the mechanism of cortisone induced granulocytosis. J Clin Invest 47:249-260,1968.

7 Boersma-Slütter W., Broekman A., Lagra H.M., Minderaa P.H.: Sport, een Riskante Zaak. Gen en Sport 12:41-49,1978.

8 Booth F.W., Watson P.A.: Control of adaptations in protein levels in response to exercise. Federation Proc 44:2293-2300, 1985.

9 Buyze G.: Serum enzyme actlvity and physical condition. J Sport Med 16:155-164,1979.

10 Casoni $I_{., y}$ Borsetto C., Caulcchi A., Mariinelli S., Conconi F.: Reduced hemoglobin concentration and red cell hemoglobinisation in Italian marathon and ultra-marathon runners. Int $\mathbf{J}$ Sports Med 6:176-179,1985.

11 CBS, overledenen naar doodsoorzaak, leettijd on geslacht in het jaar 1982, 1983 en 1984.

12 Cerny F.: Protein metabollsm during two hour ergometer exercise. Proceedings of the second International symposium on biochemistry of exercise Magglingen 1973. Howald $H_{\text {, }}$ and Poortmans J.R. (ed), Birkhäuser Verlag Basel, pp 232-237.

13 Costill D.L., Bowers R., Branam G., and Sparks K.: Muscle glycogen utilization during prolonged exercise on successive days. J Appl Physiol 31(6):834-838,1971.

14 Costill D.L., Golnick P.D., Jansson E.J., Saltin B., Stein E.M: Glycogen depletion pattern in human muscle flbers during distance running. Acta Physlol Scand 89:374-383,1973.

15 Costill D.L., Maglisho E.W., Fitts R.,Morgan W., Wilmore J., Kuipers H.: Overtralining: physlcal and psychologlcal effects of a sudden increase in training. Med Sici Sports Exerc (abstract) 19(2):S77,1987.

16 Costill D.L., Miller J.M.: Nutrition for endurance sport: carbohydrate and fluid ballance. Int $J$ Sports Med 1:2-14,1980. 
17 Davidson R.J.L., Robertson J.D., Galea G., and Maughan R.J.: Hematological Changes associated with marathon running. Int $J$ Sports Med 8:19-25,1987.

18 Dawson A.A., Ogston D.: Exercise-induced thrombocytosis. Acta Haematol 42:241-246,1969.

19 Dessypris A., Kuoppasalmi $K_{*}$, Adllercreutz $\mathbf{H}_{* \text {." Plasma }}$ cortisol, testosterone, androstenedione and luteinizing hormone in a non-competitive marathon run. J Steroid Bloch 7:33-37,1976.

20 Devereaux M.D., Lachmann S.: Athletes Attending a Sport Injury Clinic - a Review. Brit J Sports Med 17(4):137-142, 1983.

21 Dickson D.N., Wilkinson R.L., Noakes T.D.: Effects of ultra marathon training and racing on haematologic parameter and serum ferritin levels in well trained athletes. Int J Sports Med 3:111-117,1982.

22 Dix C.J., Hassall D.G., Bruckdorfer R.: The increased sensitivity of platelets to prostacyclin in marathon runners. Thromb Haemostas 51(3):385-387,1984.

23 Dohm G.L., Hecker A.L., Brown W.E., Klain G.J., Puente, Askew E.W., Beecher G.R.: Adaptation of protein metabolism to endurance training. Increased amino acid oxldation In response to training. Biochem $J$ 164:705-708,1977.

24 Dolmans I.: Thesis. Plotse dood bij sport. 1983.

25 Dufaux B., Assmann G., Order U., Holderath A., Hollmann W.: Plasma llpoproteins, hormones, and energy substrates during the first days after prolonged exercise. Int $J$ Sports Med 2: 256-260, 1981 .

26 Dufaux B., Hoederath A., Heck H., Hollmann W.: Serum testosterone levels during the first hours and days after a prolonged physical exercise and the influence of physical training. Fourth Int Symp Biochem Exerc, abstract 47, Brussels, 1979 .

27 Dufaux B., Hoederath A., Streitberger I., Hollmann W., Assmann G.: Serum ferritin, transferrin, haptoglobin and iron in middle and long-distance runners, elite rowers and professional racing cycilists. Int J Sports Med 2:43-46,1981.

28 Elchner E.R.: Exerclse and Heart Disease. Am J Med 75:1008$1023,1983$.

29 Fellman N., Coudert J., Jarrige J.F., Bedu M., Denis C., Boucher D., Lacour J.R.: Effects of endurance training on the androgenic response to exercise in man. Int $J$ Sports Med 6: 215-219,1985.

30 Fletcher K.P., Eadle M.A., Eadle D.: Pre-Race drop-out from the Glascow Marathon. Brit J Sports Med 20(2):74-76, 1986.

31 Fox Edward L.: Sports Physiology. Ultgever Saunders College, Philadelphla, 1979.

32 Franke Von A., Franke K.: Epidemiologie von Untällen und Fehibelastungsfolgen beim Sport. Med und Sport 6:184-189, 1980. 
33 Freedman, M., Altszuler N., Karpatikin S.: Presence of a non platelet pool. Blood 50:419-425, 1977 .

34 Galun E., Burstein R., Assia E., Tur-Kaspa I., Rosenblum, Epstein $Y_{a}$ : Changes of white blood cell count during prolonged exercise. Int $J$ Sports Med 8:253-255,1987.

35 Gimenez M., Mohan-Kumar T., Humbert J.C., de Talance $\mathbf{N}$., Buisine J.: Leukocyte, Iymphocyte and platelet response to dynamic exercise. Duration or intensity effect? Eur $J$ Appl Physiol 55:465-470,1986.

36 Gimenez M., Mohan-Kumar T., Humbert J.C., de Talance N., Buisine J.: Leukocyte, lymphocyte and platelet response to dynamic exercise. J Sports Med 27:172-177,1987.

37 Gollinick P.D., Plehl K, Saubert C.W., Armstrong R.B., Saltin B.: Diet, exercise and glycogen changes in human muscle fibers. J Appl Physiol 33(4):421-425,1972.

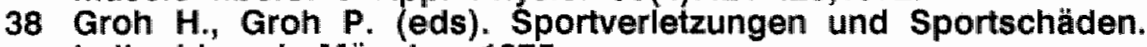
Lutipold-werk München,1975.

39 Guglielmini C., Paolini A.R., and Conconl F.: Variations of serum testosterone concentrations after physical exercise of different duration. Int J Sports Med 5:246-249,1981.

40 Haskell W.L.: Sudden cardiac death during vigorous exercise Int $J$ Sports Med 3:45-48,1982.

41 Haycock C.E.: Susceptibility of women athletes to injury. JAMA 236:163-165,1976.

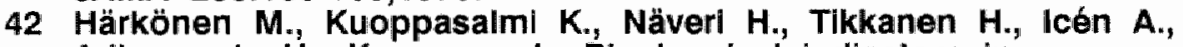
Adlercreutz $H_{\text {., }}$ Karvonen J.: Bilochemical indlcators in diagnosis of overstrain condition in athletes. Olymplc Scientific congress. University of Oregon, Eugene,1984.

43 Hermens W.Th., Willems G.M., Davids H.A.: Enzymatic assesment of myocardial injury after infarction or cardlac surgery. Is isoenzyme analysis necessary? Clin Chim Acta 156:235-246,1986.

44 Hille von E.: Verletzungen beim Jogging. Deuts Zeit Sportmed 10:265-268,1981.

45 Hoeberigs J.H.: Traumatologische aspecten van het langeatstandslopen. Gen en Sport 3:72-77,1984.

46 Hoepelman: Bloedarmoede door sportbeoefening: een onschuldige bljwerking van een gezonde hobby. NTVG:155-157,1986.

47 Hollmann $W_{\text {, }}$ Th. Hettinger: Sportmedizin - Arbelts- und Trainingsgrundlagen. F.K. Schattauer Verlag, Stuttgart-New York, 1980 .

48 Inter/view b.v.: Hardlopen in cljfers. Instituut voor marktinformatie. Dec, 1985.

49 James L.: Injuries to runners. Am J Sports Med 6(2):40-50, 1978.

50 Janssen G.M.E., Kulpers H., Kelzer H.: Plasma CPK and AST activity, and plasma testosterone after $200 \mathrm{~km}$ speed skating. Med Scll Sports Exerc 18 (suppl):205,1986.

51 Janssen G.M.E., Kulpers H., Kelzer H.A., Geurten P., Kranenburg van G., Does R.J.M.M.: Splerbeschadiglng, prestatievermogen en herstel na verschillende soorten wegwedstrijden. Gen en Sport 20(5) "190-195,1987. 


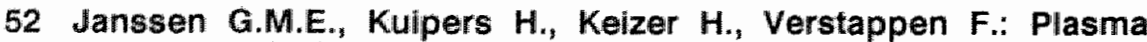
enzyme activities and running performance in a maximal treadmill test before and after a $30 \mathrm{~km}$ race or a marathon. Int J Sports Med 5(suppl):98-99,1984.

53 Janssen G.M.E., Kuipers H., Verstappen F., Keizer H.: Muscle damage and recovery after a marathon compared to a $25 \mathrm{~km}$ race (abstract). Med Sci Sports Exerc 16:200,1984.

54 Jansson E.J., Kayser L.: Substrate utilization and enzymes in skelletal muscle of extremely endurance-trained man. J Appl Physiol 62:999-1005,1987.

55 Kaman R.L.: The effects of exercise on serum enzymes. Osteopath Ann 5:442-448,1977.

56 Karlsson J.: Lactate and phosphagen concentration in working muscle of man with special reference to oxygen deficit at onset of work. Acta Physiol Scand Suppl 358,1971.

57 Karlsson J., Nordesjoe L.O., Jorfeldt L., Saltin B.: Muscle lactate, ATP, and CP levels during excercise after physical tralning in man. $J$ Appl Physiol 33:199-203,1972.

58 Kelly F.J., McGrath J.A., Goldspink D.F., Cullen M.J.: A morphological/biochemical study on the actions of corticosterolds on rat skeletal muscle. Muscle and Nreve 9: 1-10,1986.

59 Kindermann W.: Das Übertraining - Ausdruck einer vegetativen Fehlsteuerung. Dtsch Z Sportmed 8:238-244,1986.

60 Knulst W., Schoonderwoerd L.: Sociale en Culturele Studies-4, 1980.

61 Kowal D.M.: Nature and causes of injuries in women resulting from an endurance training. Am J Sports Med 8(4):265-269,1980

62 Kranenborg N.: Sportbeoefening en Blessures. $T$ Soc Geneesk 60(9):204-227,1982.

63 Kuipers H., Drukker J., Frederik P.M., Geurten P., Kranenburg van G.: Muscle degeneration after exercise in rats. Int $\mathbf{J}$ Sports Med 4:45-51,1983.

64 Kuoppasalmi K., Adlercreutz H.: Interaction between catabolic and anabollc sterold hormones In muscular exercise. In Fotherby \& Pal (eds): Exercise endocrinology, pp 65-120. Walter de Gruyter, Berlin, New York, 1985.

65 Kuoppasalmi K., Naverl N., Kosumen K.: Plasma steroid levels in muscular exercise. International serles on sport sciences vol. 11B Blochemistry of exercise IV-B. Poortmans J., Nisset G. (eds): Univ. Park Press, Baltimore, 1981.

66 Leon A.S., Blackburn $H_{\text {.: }}$ The relationship of physical activity to coronary heart disease and life expectancy. An $N$ $Y$ AC of Sci 301:561-578,1977.

67 Llesen von H., Ludemann E., Schmengler D., Föhrenbach R., Mader An: Trainingssteurerung im Hochleistungssport: einige Aspekte und Beispiele. Dtsch Z Sportmed 1:8-18,1985.

68 Luidinga F., Rogmans W.H.J." Epidemiologie van acute sportletsels. Ned Tijdschr Geneesk 129(22):1051-1054,1985.

69 Lysens R., Ostyn M.: Prolegomena bij de preventle van sportletsels. Hermes (Leuven) 17:85-94,1984. 
70 Magazanik A., Shapiro Y., Meytes D., Meytes 1.: Enzyme blood levels and water balance during a marathon race. J Appl Physiol 36(2):214-217,1974.

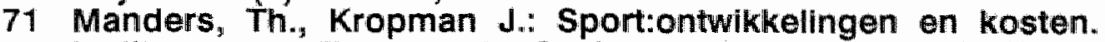
Instituut voor Toegepaste Sociale Wetenschappen (ITS), CIP-gegevens, Koninklijke Bibliotheek Den Haag, 1987.

72 Maron, M.B., Horvath S.M.: The marathon: a history and review of the literature. Med Sci in Sports $10(2): 137-150,1978$.

73 Martin D:: Grundlagen der Trainingslehre Tell 1 Band 63/64, Verlag Karl Hofmann - Schorndorf,1979.

74 Martin D.: Grundlagen der Trainingslehre Tell 2 Band 77/78, Verlag Karl Hofmann - Schorndorf,1980.

75 Meyer R.A., Dudley G.A., Terjung R.L.: Ammonia and IMP in different skeletal muscle fibers after exercise in rats. $J$ Appl Physiol 49:1037-1041,1980.

76 McKechnie J.K., Leary W.P., Noakes T.D.: Metabollc responses to a $90 \mathrm{~km}$ running race. S Afr med J 61:482-484, 1982.

77 Moorthy, A.V., Zimmerman W.: Human leukocyte response to an endurance race. Eur J Appl Physiol 38:271-276,1978.

78 Newsholme E.A., Start C.: Regulation in Metabolism. John Wiley \& Sons, Chichester,1981.

79 Newsholme E.A.: The glucose/fatty acid cycle and physical exhaustion. Im: Human muscle fatique: physiologlcall mechanisms. Pitman Medical, London, pp 89-101 1981.

80 Noakes T.D.: Heart disease in marathon runners: a review Med Sci Sports Exerc 19(3):187-194,1987.

81 Noakes T.D., Carter J.W.: The responses of plasma blochemical parameters of a $56 \mathrm{~km}$ race in novice and experienced ultra-marathon runners. Eur J Appl Physiol 49:179-186,1982.

82 Noble B.J., Maresh C.M.: Cardiorespiratory and perceptual recovery from a marathon run. Med Scil Sport 11(3):239-243, 1979.

83 Norregaard-Hansen $K .$, Bjerre-Knudsen J., Brodthage $U_{*, y}$ Jordal R. Pauko P.E.: Muscle cell leakage due to llong distance training. Eur \ Appl Physiol 48:177-188,1982.

84 Opstad P.K., Aakvaag A... Decreased serum levels of estradiol, testosterone and prolactin during prolonged physical strain and sleep deprivation and the influence of a high calory diet. Eur $J$ Appl Physiol 49:343-348,1982.

85 Paffenbarger R.S., Hyde R.T.: Exercise in the primary prevention of ischemic heart disease. in Current Therapie in Sports Medicine 1985-1986, Welsh R.P. and Shephard R.J.(eds). B.C. Decker Inc. pp 76-80, 1985.

86 Petursson S.R., and Chervenick P.A.: Effects of hypoxla on megakaryocytopoiesis and granulopolesis. Eur J Haematol 39: 267-273,1987.

87 Plass R., Kokot K., Schaefer R.M., Teschner M., Gilge U., Heidland A.: Auswirkung von Mittel- und Langstreckenlauf auf polymorphkernige Leukozyten. Deutsc Zeitschr Sportmed 38 (4): $168-172,1987$. 
88 Prior J.C.: Endocrine "conditioning" with endurance training. A preliminary review. Can J Appl Spt Scil 7(3):148-157,1982.

89 Remes K., Kuoppasalmi K., Adlercreutz H.: Effect of physical exercilse and sleep deprivation on plasma androgen levels: modifying effect of physical titness. Int $J$ Sports Med 6 : $131-135,1985$.

90 Rogmans W.H.: Cijfers Ongevallen in Nederland. Publicatie Veiligheidsinstituut, 1982.

91 Aonkainen H.R.A., Pakarinen A.J., Kauppilla A.J.I.: Adrenocortcal function of female endurance runners and Joggers. Med Sci Sports Exerc 18:385-389,1986.

92 Rose L.I.: Serum enzymes after marathon running. J Appl Physiol. 29(3):355-357,1970.

93 Aöcker L., Kírsch K.A., Stoboy H.: Plasma volume, albumin and globulin concentrations and their intravascular masses. A comparative study in endurance athletes and sedentary subjects. Eur J Appl Physiol 36:57-64,1976.

94 Schmidt K.G., Rasmusson J.W.: Exercise-induced changes in the in vivo distribution of in-labelled platelets. Scand J Haematol 32:159-166,1984.

95 Scrimgeour A.G., T.D. Noakes, B. Adams, and K. Myburgh The influence of weekly training distance on fractional utilization of maximal aeroblic capacity in marathon and ultramarathon runners. Eur \ Appl Physiol 55:202-209,1986.

96 Seene T., Viru A.: The catabolic effects of glucocorticold on different types of skeletal muscle fibres and its dependance upon muscle activity and interaction with anabolic steroids. $\mathrm{J}$ Steroid Blochem 16:349-352,1982.

97 Seggeser B.: Atiologie von reversiblen und irreversiblen Sportschäden. Schwelz Ztschr Sportmed 31:81-86,1983.

98 Sherman W.M., Costill D.L., Fink W.J.: Effect of a $42.2 \mathrm{~km}$ footrace and subsequent rest or exercise on muscle and enzymes. J Appl Physiol 55(4):1219-1224,1983.

99 Slest G., Galseau M.M.: Variations of plasmatic enzymes during exercise. Enzyme 17:179-195,1974.

100 Slscovick D.S.", Weiss N.S., Fletcher R.H., Lasky T.: The incidence of primary cardiac arrest during vigorous exercise. N Engl J Med 311:874-877,1984.

101 Sjödin B., Svedenhag J.: Applied physilogy of marathon running. Sports Med (review article) 2:83-99,1985.

102 Sutton J.R., Toews C.J., Ward G.R., and Fox I.H.: Purine metabolism during strenuous muscular exercise in man. Metabolism 29:254-259,1980.

103 Taylor C., Rogers G., Goodman C., Baynes R.D.: Hematologic, iron-related, and acute-phase protein responses to sustained strenuous exercise. J Appl Physiol 62(2):464-469,1987.

104 Temple C: Sports injuries. Hazards of jogging and marathon running. Brit J Hosp Med 29:237-239,1983.

105 Thompson P.D., Funk E.J., Carleton R.A., Sturner W.Q.: Incidence of Death during Jogging in Rhode Island 1975 through 1980. JAMA 247(18):2535-2538,1982. 
106 Tijdsbestedingsonderzoek 1975-1980. Sociale en Culturele studies.

107 Van Mechelen W., Hlobil $H_{\text {., }}$ Kemper H.C.G.: How can sports injuries be prevented? NISGZ publication Nr. 25, Oosterbeek, The Netherlands, 1987.

108 Viru A.: Hormones in muscular activity. vol. $\mathrm{II}_{n}$ Adaptive effect of hormones in exercise. CRC Press, Inc. Boca Raton, Florida, USA, 1985.

109 Warhol M.J., Slegel A.J., Evans W.J., Silverman L.M.: Skeletal muscle injury and repair in marathon runners after competition. Am J Pathol 118:331-339,1985.

110 Wijn de, Jongste de J.L., Mosterd W., Willebrand D.: Haemoglobin, packed cell volume, serum iron and Iron binding capacity of selected athletes during training. J Sports Med Phys Fitness 11:42-51,1971.

111 Willems G.M., Muijtjens A.M.M., Lambi F.H.H., Hermens W.Th. Estimation of circulatory parameters in patients with acute myocardial infarction. Significance for calculation of enzymatic infarct size. Cardlovasc Res 13:578-587,1979.

112 Willems G.M., Visser M.D., Krill M.T.A, Hermens W.Th.: Quantitative analysis of plasma enzyme levels based upon simultaneous determination of different enzymes. Cardiovasc Res 16:120-131,1982.

113 Williamson M.R.: Anemie in runners and other athletes. Phys and Sports Med 9(6):73-79,1981.

114 Wintrobe M.W.(ed): Clinical Hematology. Philadephla, Lea \& Febiger, pp 215-217,1981.

115 Wishnitzer R., Vorst E., Berrebi A.: Bone marrow Iron depression in competitive distance runners. Int $J$ Sports Med 4:27-30,1983.

116 Wolfe R.R., Goodenough R.D., Wolfe M.H., Royle G.T., Nadel E.R.: Isotopic analysis of leucine and urea metabolism in exercising humans. J Appl Physiol 52(2):458-466,1982.

117 Wyndham C.H.: Heat stroke and hyperthermila in marathon runners. Ann N Y Ac Sc 301:128-138,1977.

118 Yoshimura $H .:$ Anemia during physical training; sports anemia. Nutrition Reviews 28:251-253,1970. 


\section{Chapter 2 Materials, methods and procedures}

\section{Introduction}

In this study we opted for an endurance sport since the relationship between physical stress and physical stress tolerance can better be characterized by endurance training than by explosive activities.

Running was chosen because overuse problems mainly occur in running.

Additional reasons for choosing running as endurance sport were of a more practical nature: running being possible under almost every climatic condition and because of the presence of experience in giving training in this field. The study started with untrained people so that a build-up of the training which gave similar physiological workload to all the subjects could be designed. In this way the factors which might interfere with the recovery processes, such as the number of years of training and the kind of training, were banned. The research was set up longitudinally in order to follow the devellopment of untrained people in their trainingadaptation, to check overloading and muscle damage if any and to get an idea of recovery processes.

\section{Procedure of enrollment}

Through an article in regional newspapers subjects were asked to volunteer in this study. Within a period of nine days more than 500 people reacted by returning an application form (name, address, sex, age, weight, height and reasons). Everyone above the age of 20 was invited to attend an information meeting. Together with the invitation for this meeting they received a questionnaire (profession, job, activities in sport, education, smoking and drinking habits). During the meeting the plan and the aim of the study were explained in detail, li.e. the time the subjects had to spend the interventions and inconveniences associated with the study. Only those subjects who attended the meeting, who were untrained and filled out the questlonnaire, were considered for participation. The criteria for being endurance-untrained were the following. Physically active for a maximum of three times a week, maximal running distance $25 \mathrm{~km}$ per week or a maximum distance run of 15 $\mathrm{km}$ in one training session during the past year. After selection it appeared that more than $80 \%$ of the participants ran less than 10-15 km per week with a maximum of $\mathbf{B} \mathrm{km}$ or were totally untrained. Moreover, the subjects who ran more than 15 but less than $25 \mathrm{~km}$ per week had a similar training status compared to the total group during the last 6 weeks before the first contest.

From the group of 265 people who met these criteria, a non-select sample of 114 subjects was taken. Before the start of the project all participants signed an informed consent statement. 


\section{Outline of the study}

The study can be divided into three periods ( 25 weeks, 20 weeks and 35 weeks), each terminated with a contest of 15,25 and $42 \mathrm{~km}$ (marathon $=42.195 \mathrm{~km}$ ) respectively (Fig. 2.1). During the first period the longest distance covered during a training session was $12 \mathrm{~km}$; in the second period this was less than $21 \mathrm{~km}$ and during the third period this was less than $35 \mathrm{~km}$. Thus the contests were the longest distances covered in the training periods. The contests in which the subjects participated, were all organized by the Dutch Athletic Association (KNAU). About six weeks before the first contest the subjects were divided into two groups after consulting the volunteers. The subjects of the first group (25 males and 11 females) took part in treadmill-tests before and after each contest. In addition to these 3 muscle biopsies were taken from the $m$. vastus lateralis in each period. This group, limited in number due to avallable time and space in the laboratory, will be indicated as the treadmill group (TG). The subjects of the other group ( 57 males and 21 females) were exempted from the treadmill-tests and muscle biopsies. Instead the subjects of this group performed fleld-tests before and after each contest. The field-test consisted of running $400 \mathrm{~m}$ and $1000 \mathrm{~m}$ at maximal speed. This second group will be indicated as the fleld-test group (FG).

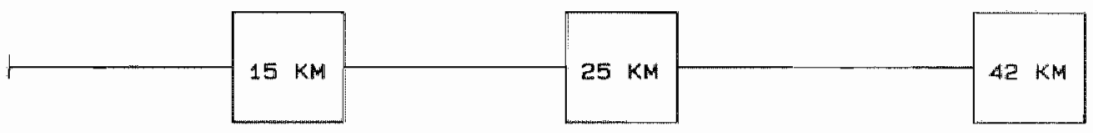

0

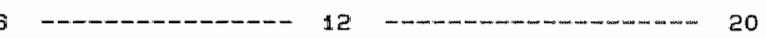

MONTHS

Flg. 2.1 Survey of the three training perlods and the distances covered in the three contests.

In Fig. 2.2 a survey is given of the test protocol of both

experimentall groups as carried out before and after each contest.

- Blood samples were drawn from an antecubltal velin with the subjects in sitting position

- Blood samples of the FG and blood samples $2,4,6,8,9,11,12,14$ and 15 of the TG were drawn between 7-10 a.m. (fasting)

- Field tests were held on an outdoor track at 7 p.m.

- Blood samples $1,3,7,10$ and 13 of the TG were drawn between 5-6 p.m.

- Blood sample 5 of the TG was drawn after 8 p.m. being 5,6 and 7-8 $\mathrm{h}$ after the start of the 15, 25 and $42 \mathrm{~km}$ contest, respectivelly

- No food or beverages (except water or coffee and tea without sugar or milk) were taken during $3 \mathrm{~h}$ before taking the blood samples mentioned under dash 4 and 5 
- To prevent clotting for most determinations one drop of a heparin solution (Tromboliquine; 5000 U.I./mll, Organon Technika, Oss) was used for 10-12 $\mathrm{ml}$ blood; K-EDTA was added to blood $(4 \mathrm{ml})$ used for the determinations of hematological parameters $(1.2 \mathrm{mg} / \mathrm{ml}$, Sherwood Medical Industries, Brunswick Nederland B.V., Den Bosch)

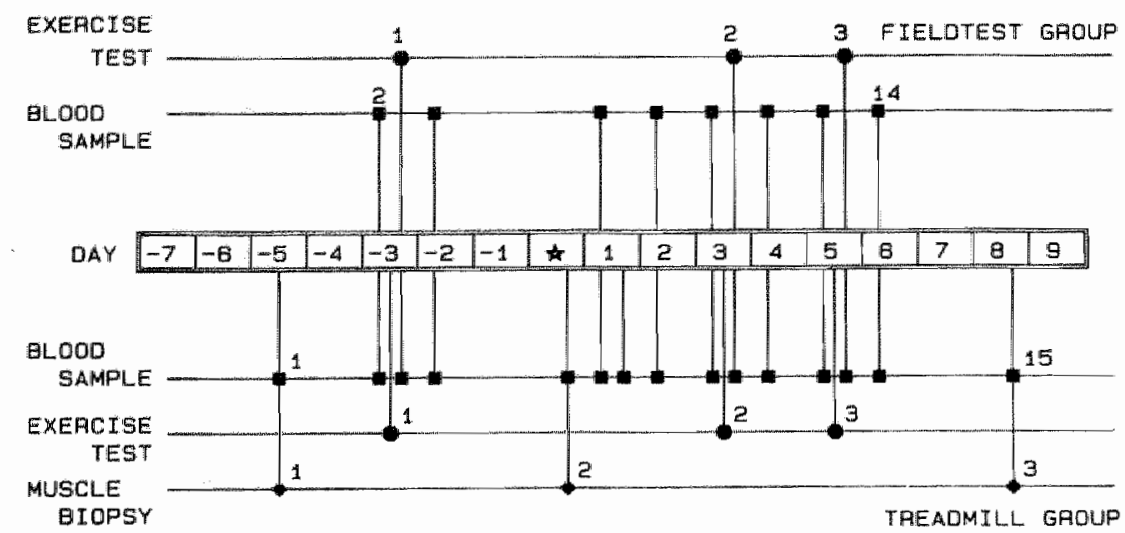

Fig. 2.2 Time schedule of blopsles, blood sampling and exerclse tests of the treadnill group and fleld-test group before and after 15,25 and $42 \mathrm{~km}$ contest.

* Indlcates contest of 15, 25 or $42 \mathrm{~km}$.

\section{Training procedure}

The training period lasted $18-20$ months. During the general preparation period the volunteers trained 3-4 times a week. A specific preparation started 6 weeks before each contest during which the subjects trained 5-6 times a week. The planning of the training was such that at fixed times and places supervised training sesslons were given in the region. During these sessions attention was paid to style and technique of running, stretching, speed, intervals, warming-up and cooling-down. At the end of the training sessions a schedule was handed out presenting the training that had to be carried out during the next 7 days. The training included three elements: long distance running, running at high speed and interval training. Those three elements of training followed each other naturally as far as the intensity is concerned. The intensity can be expressed as a percentage of either the maximal heart rate, the top speed or the maximal oxygen uptake.

On the basis of the maximal heart rate, long distance runs have to be covered at an intensity of $70-80 \%$, running at a fixed pace with an intensity of $80-95 \%$ and intervals with an intensity of $95-100 \%$. The training is mainly intended to increase the maximal oxygen uptake as well as the ability to run for periods of time at submaximal intensity $(2,9,10,13,14,21)$. The extension of the long 
distance runs (first element) with a certain intensity, in relation to the status of training is essential for an increasing aerobic metabolism. The second element of training was runining at a high pace (intensity $80-95 \%$ of max heart rate (HR)) over distances of 200-3000 $\mathrm{m}$ dependling on the training status. The last element was interval training; shorter dilstances (200-400 m) were employed in order to develop a good running technique indispensable for running at a higher speed during contests and long distance runs. These three elements were mixed in order to get good training results and avoid overload problems. In our experience this way of training appeared to be a reasonably safe method to avoid injuries.

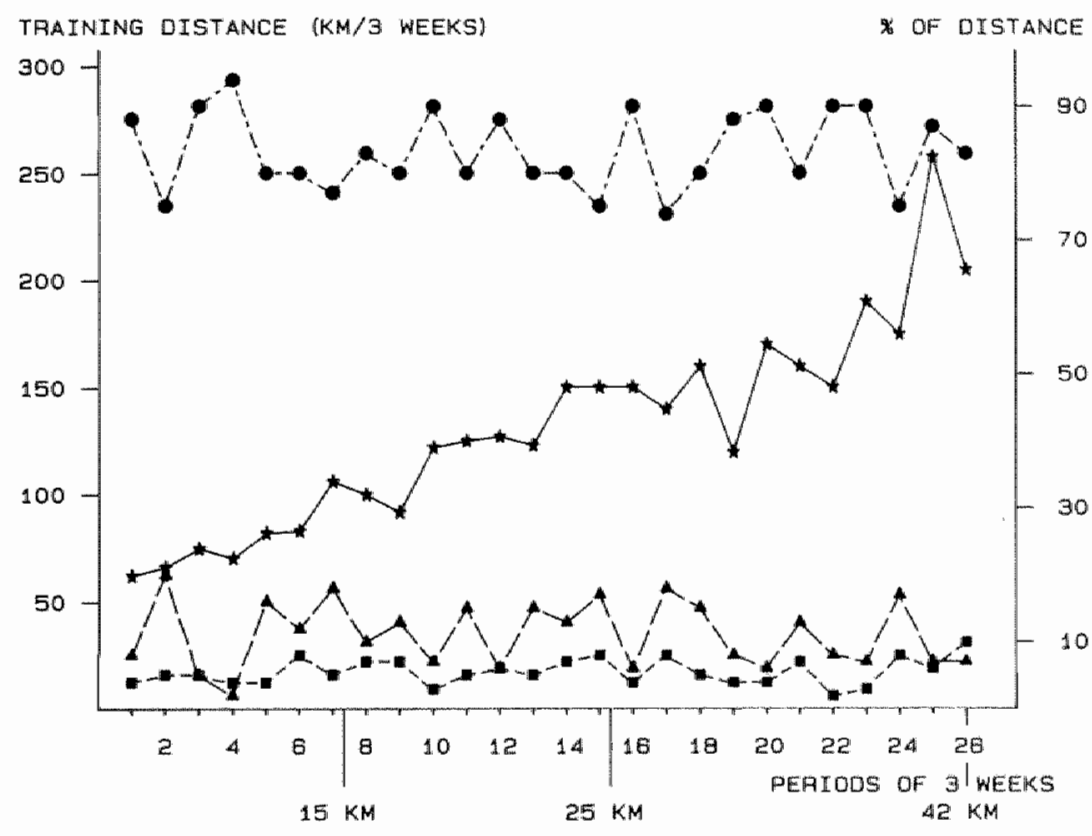

REGEND

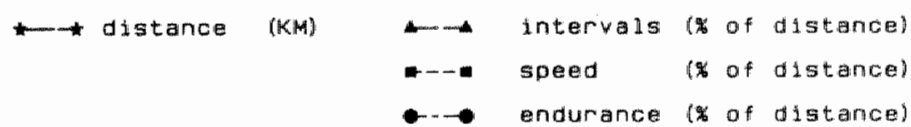

FIg. 2.3 Training programe during the experiment in perlods of 3 weeks. Intervals, speed and endurance are the training elements which together determine distance. 
By putting these three elements together a gradual undulating increase of the amount of training can be accomplished. During the first and second period of the study the duration of training was expressed in time instead of in distance to be covered. The reason for this was to obtain a similar physical load for all subjects. In order to equalize the loading during the preparation for the marathon $(42 \mathrm{~km})$, in the third period all the subjects were instructed to cover a certain distance because of the ultimate aim to run a marathon, in which the time was of minor importance. In practice, stamina (running at a rather high speed during a certain time) did not quite meet the expectations, although the endurance training at low intensity went very well. Fig. 2.3 shows the schedule of the training with the three elements in percentages of the total distance and the distance in $\mathrm{km}$ in periods of three weeks. In Table 2.1 a detailed schedule of the last 6-week period is given.

Table 2.1 Tralning schedule of the last 6 weeks before the contests

\begin{tabular}{|c|c|c|c|c|c|c|}
\hline \multirow[t]{2}{*}{$15 \mathrm{~km}$ contest } & \multicolumn{6}{|c|}{ number of weeks before the contest } \\
\hline & 6 & 5 & 4 & 3 & 2 & 1 \\
\hline distance $(\mathrm{km})$ & 45 & 22 & 20 & 45 & 28 & 10 \\
\hline$\%$ endurance run & 89 & 62 & 78 & 90 & 80 & 67 \\
\hline \% Interval run & 9 & 29 & 8 & 6 & 11 & 20 \\
\hline$\%$ speed run & 2 & 9 & 4 & 4 & 9 & 13 \\
\hline \multicolumn{7}{|l|}{$25 \mathrm{~km}$ contest } \\
\hline distance (km) & 65 & 50 & 35 & 70 & 55 & 25 \\
\hline$\%$ endurance run & 87 & 76 & 71 & 80 & 69 & 72 \\
\hline * Interval run & 8 & 16 & 20 & 14 & 22 & 16 \\
\hline \% speed run & 5 & 8 & 9 & 6 & 9 & 12 \\
\hline \multicolumn{7}{|l|}{$42 \mathrm{~km}$ contest } \\
\hline dlstance $(\mathrm{km})$ & 111 & 83 & 64 & 100 & 86 & 20 \\
\hline$\%$ endurance run & 90 & 84 & 84 & 83 & 8.4 & 75 \\
\hline \% Interval run & 4 & 10 & 6 & 8 & 5 & 10 \\
\hline * speed run & 6 & 6 & 10 & 9 & 11 & 15 \\
\hline
\end{tabular}

\section{Subjects}

The group of volunteers consisted of 31 females (age 22-41 years) and 83 males (age 21-54 year). Each subject had a medical check-up before the start of the study. In Table 2.2 personal data of the volunteers at the start of the study and 2-3 weeks after running the marathon are summarized. 
Table 2.2 Personal characteristics of male and female volunteers

\begin{tabular}{|c|c|c|c|c|c|c|c|c|}
\hline \multirow{2}{*}{$\begin{array}{l}\text { Males } \\
\text { code }\end{array}$} & \multirow{3}{*}{$\begin{array}{l}\text { At the } \\
\text { b.d. } \\
270842\end{array}$} & \multirow{3}{*}{$\begin{array}{c}\text { start } \\
\text { hi } \\
187\end{array}$} & \multicolumn{3}{|c|}{ of the study } & \multirow{2}{*}{\multicolumn{3}{|c|}{$\begin{array}{l}\text { After running the marathon } \\
\qquad \mathrm{w} \quad \mathrm{f}\end{array}$}} \\
\hline & & & $w$ & $f$ & $w_{n}$ & & & \\
\hline $005 \mathrm{JR}$ & & & 75.5 & 19.2 & 230 & 73.1 & 16.2 & 230 \\
\hline $006 \mathrm{FW}$ & 160456 & 186 & 68.0 & 08.1 & 225 & - & - & - \\
\hline $022 \mathrm{~J}$ & 140848 & 181 & 73.5 & 17.1 & 260 & - & - & - \\
\hline $027 \mathrm{SK}$ & 210255 & 166 & 65.0 & 14.1 & 235 & - & - & - \\
\hline $032 \mathrm{PM}$ & 040444 & 189 & 75.0 & 17.7 & 235 & - & - & - \\
\hline $033 \mathrm{Wk}$ & 190243 & 177 & 67.6 & 16.7 & 250 & 66.9 & 12.8 & 310 \\
\hline $048 \mathrm{JC}$ & 261052 & 178 & 75.0 & 13.8 & 275 & 75.0 & 13.8 & 330 \\
\hline O58 WP & 061246 & 179 & 75.0 & 15.8 & 310 & 71.5 & 12.6 & 337 \\
\hline $071 \mathrm{~J}$ & 070545 & 171 & 58.0 & 16.5 & 240 & 61.0 & 18.9 & 235 \\
\hline $073 \mathrm{~J}$ & 130552 & 177 & 77.9 & 19.5 & 275 & 75.9 & 18.9 & 310 \\
\hline $078 \mathrm{TP}$ & 171249 & 182 & 72.0 & 14.2 & 265 & 66.0 & 09.2 & 300 \\
\hline 09100 & 050943 & 181 & 80.5 & 15.6 & 315 & 78.1 & 14.0 & 370 \\
\hline $093 \mathrm{HM}$ & 100347 & 175 & 76.5 & 18.0 & 300 & 76.6 & 19.2 & 320 \\
\hline 105 UU & 301258 & 172 & 64.0 & 08.1 & 265 & 66.0 & 08.6 & 272 \\
\hline 10790 & 170356 & 186 & 90.0 & 13.7 & 305 & - & - & - \\
\hline $116 \mathrm{MN}$ & 080341 & 172 & 71.0 & 21.8 & 200 & 66.0 & 18.5 & 250 \\
\hline $117 \mathrm{CK}$ & 280831 & 183 & 74.0 & 15.5 & 300 & 73.5 & 12.6 & 340 \\
\hline $122 \mathrm{LM}$ & 080338 & 177 & 68.0 & 14.0 & 255 & 70.0 & 16.7 & 222 \\
\hline $123 \mathrm{FH}$ & 290738 & 187 & 75.3 & 15.6 & 258 & 7.4 .3 & 12.2 & 315 \\
\hline $129 \mathrm{PL}$ & 18.0254 & 183 & 72.0 & 15.0 & 235 & 72.5 & 14.2 & 250 \\
\hline $134 \mathrm{LB}$ & 260542 & 182 & 74.0 & 15.6 & 335 & 71.0 & 10.4 & 370 \\
\hline $135 \mathrm{RS}$ & 090664 & $18: 8$ & 85.0 & 12.9 & 310 & - & - & - \\
\hline $138 \mathrm{FN}$ & 280744 & 178 & 77.7 & 18.9 & 195 & - & - & - \\
\hline $156 \mathrm{HB}$ & 260753 & 183 & 76.0 & 12.2 & 350 & 75.10 & 10.4 & 375 \\
\hline $169 \mathrm{MJ}$ & 06.1038 & 179 & 89.0 & 26.2 & 245 & - & - & - \\
\hline $177 \mathrm{WJ}$ & 110353 & 184 & 64.0 & 06.9 & 290 & - & - & - \\
\hline $179 \mathrm{~TB}$ & 010744 & 179 & 76.1 & 21.4 & 275 & 77.7 & 17.7 & 305 \\
\hline $184 \mathrm{FM}$ & 100358 & 177 & 68.9 & 14.4 & 275 & 69.2 & 11.0 & 315 \\
\hline $189 \mathrm{TP}$ & 231240 & 177 & 67.0 & 17.2 & 235 & 69.0 & 15.6 & 300 \\
\hline $193 \mathrm{ED}$ & 300660 & 173 & 63.0 & 13.7 & 270 & 62.0 & 13.3 & 290 \\
\hline $194 \mathrm{WR}$ & 010754 & 179 & 72.5 & 15.4 & 280 & 71.0 & 17.7 & 280 \\
\hline $197 \mathrm{AL}$ & 100849 & 176 & 69.0 & 12.6 & 275 & - & - & - \\
\hline 200 TK & 070358 & 189 & 83.0 & 13.7 & 300 & - & - & - \\
\hline $202 \mathrm{PH}$ & 15034.8 & 171 & 72.3 & 18.0 & 275 & 73.5 & 21.5 & 310 \\
\hline $204 c G$ & 301147 & 181 & 76.5 & 19.5 & 175 & - & - & - \\
\hline $208 \mathrm{~GB}$ & 271149 & 180 & 69.0 & 14.6 & 300 & 72.0 & 14.2 & 350 \\
\hline $211 \mathrm{FB}$ & 300659 & 180 & 68.0 & 09.6 & 265 & - & - & - \\
\hline 228i MR & 010356 & 174 & 60.7 & 10.1 & 270 & - & - & - \\
\hline $230 \mathrm{PR}$ & 050458 & 187 & 78.0 & 09.1 & 318 & 75.0 & 09.1 & 335 \\
\hline $235 @ 0$ & 170338 & 178 & 60.0 & 14.5 & 250 & 61.0 & 14.5 & 265 \\
\hline 238 GN & 110163 & 181 & 79.8 & 15.5 & 300 & 77.8 & 12.9 & 325 \\
\hline $241 \mathrm{WB}$ & 030860 & 188 & 76.0 & 11.5 & 265 & - & - & - \\
\hline 248 $M$ & 080654 & 173 & 79.0 & 18.0 & 244 & 75.0 & 20.7 & 245 \\
\hline 256. LL & 311237 & 175 & 69.7 & 23.4 & 2110 & 68.5 & 23.7 & 260 \\
\hline $265 \mathrm{LB}$ & 300552 & 183 & 78.0 & 17.1 & 220 & - & - & - \\
\hline 270 SG & 110851 & 179 & 78.0 & 18.9 & 250 & - & - & - \\
\hline $275 \mathrm{BB}$ & 030157 & 173 & 65.0 & 11.0 & 250 & 65.0 & 15.4 & 275 \\
\hline $313 \mathrm{HN}$ & 041143 & 184 & 75.0 & 15.6 & 275 & - & - & - \\
\hline
\end{tabular}




$\begin{array}{llllllllll}318 & \mathrm{JN} & 271245 & 168 & 67.0 & 17.4 & 250 & 65.7 & 17.6 & 270 \\ 331 \mathrm{SH} & 070554 & 178 & 85.3 & 21.5 & 320 & 78.0 & 18.9 & 350 \\ 340 \mathrm{WH} & 171053 & 172 & 66.0 & 12.2 & 252 & 68.0 & 13.8 & 277 \\ 341 \mathrm{SC} & 250144 & 185 & 82.0 & 20.8 & 268 & 79.5 & 20.0 & 310 \\ 356 \mathrm{LW} & 290439 & 170 & 65.0 & 21.1 & 195 & 64.0 & 18.9 & 235 \\ 361 \mathrm{TL} & 260150 & 181 & 70.5 & 21.9 & 217 & - & - & - \\ 363 \mathrm{WS} & 140259 & 177 & 73.0 & 15.1 & 210 & - & - & - \\ 366 \mathrm{KN} & 080762 & 181 & 60.0 & 07.5 & 255 & - & - & - \\ 368 \mathrm{GJ} & 150464 & 185 & 73.2 & 06.2 & 345 & - & - & - \\ 372 \mathrm{GK} & 121143 & 177 & 78.0 & 20.0 & 253 & 73.0 & 22.1 & 300 \\ 389 & \mathrm{JJ} & 080444 & 183 & 84.0 & 27.6 & 285 & 82.0 & 30.1 & 300 \\ 390 & \mathrm{WW} & 090359 & 186 & 74.0 & 13.7 & 268 & 74.0 & 15.1 & 265 \\ 398 \mathrm{HB} & 170153 & 172 & 73.1 & 18.6 & 235 & - & - & - \\ 400 \mathrm{PE} & 170751 & 182 & 77.1 & 13.0 & 333 & 84.1 & 17.1 & 385 \\ 402 \mathrm{HW} & 210943 & 172 & 76.8 & 26.2 & 245 & 73.1 & 20.4 & 260 \\ 411 & \mathrm{FS} & 241145 & 175 & 85.0 & 17.7 & 280 & 77.5 & 17.7 & 287 \\ 422 \mathrm{LN} & 190363 & 185 & 63.0 & 11.0 & 240 & - & - & - \\ 427 \mathrm{JP} & 100250 & 176 & 83.0 & 22.1 & 258 & - & - & - \\ 430 \mathrm{MK} & 111149 & 173 & 62.0 & 15.4 & 255 & 61.0 & 15.0 & 268 \\ 432 \mathrm{HL} & 301153 & 184 & 65.0 & 06.9 & 210 & 67.5 & 11.1 & 260 \\ 501 \mathrm{WK} & 280543 & 184 & 73.0 & 16.7 & 225 & 73.0 & 16.2 & 275 \\ 503 \mathrm{TC} & 060861 & 168 & 68.5 & 11.5 & 300 & 65.9 & 10.1 & 325 \\ 504 \mathrm{FS} & 010151 & 185 & 89.0 & 18.0 & 295 & 94.0 & 21.5 & 327 \\ 505 \mathrm{HS} & 210752 & 181 & 81.5 & 21.9 & 265 & - & - & - \\ 506 \mathrm{JS} & 250353 & 178 & 80.0 & 15.4 & 240 & 70.0 & 14.2 & 275 \\ 507 \mathrm{ML} & 240260 & 182 & 88.0 & 13.7 & 300 & - & - & - \\ 511 \mathrm{RD} & 130151 & 193 & 83.0 & 15.1 & 270 & 81.0 & 17.4 & 312 \\ 513 \mathrm{HH} & 170659 & 185 & 74.5 & 10.5 & 310 & - & - & - \\ 514 \mathrm{HS} & 090763 & 179 & 62.0 & 12.0 & 285 & 65.0 & 13.7 & 287 \\ 515 \mathrm{FH} & 050261 & 181 & 69.0 & 09.1 & 310 & 69.0 & 16.4 & 320 \\ 516 \mathrm{RC} & 200861 & 178 & 66.5 & 10.1 & 282 & - & - & - \\ 517 \mathrm{BH} & 170645 & 185 & 74.4 & 13.4 & 275 & 71.7 & 16.0 & 300 \\ 518 \mathrm{JS} & 020752 & 184 & 69.5 & 06.9 & 275 & 72.0 & 13.0 & 288 \\ 519 \mathrm{CF} & 200552 & 174 & 65.0 & 15.0 & 250 & 64.0 & 16.2 & 300 \\ 525 \mathrm{MK} & 030748 & 172 & 66.0 & 15.7 & 315 & - & - & - \\ & & & & & & & & & \end{array}$

Females At the start of the study After running the marathon

\begin{tabular}{|c|c|c|c|c|c|c|c|c|}
\hline de & b.d. & $\mathrm{h}$ & $w$ & $f$ & $W_{m}$ & $w$ & & $W_{m}$ \\
\hline 028 AK & 030655 & 164 & 61.0 & 29.1 & 165 & $\overline{-}$ & - & - \\
\hline $034 \mathrm{MK}$ & 140345 & 160 & 59.5 & 26.9 & 150 & 58.3 & 27.2 & 185 \\
\hline 070 LلJ & 300960 & 169 & 54.0 & 22.3 & 150 & - & - & - \\
\hline 074 LJ & 160454 & 170 & 56.9 & 26.7 & 180 & - & - & - \\
\hline $077 \mathrm{CS}$ & 250456 & 168 & 60.9 & 25.9 & 190 & 59.0 & 21.5 & 200 \\
\hline 092 AO & 100347 & 163 & 57.2 & 23.7 & 200 & 56.2 & 16.5 & 233 \\
\hline $106 \mathrm{FM}$ & 280558 & 174 & 61.0 & 23.8 & 200 & - & - & - \\
\hline $121 \mathrm{CT}$ & 557 & 168 & 52.0 & 22.7 & 200 & 52.0 & 25.6 & 201 \\
\hline $180 \mathrm{~PB}$ & 46 & 175 & 66.7 & 30.0 & 180 & 68.0 & 28.8 & 235 \\
\hline $203 \mathrm{LH}$ & 28 & 155 & 62.5 & 31.8 & 175 & - & - & - \\
\hline $205 \mathrm{RL}$ & 030346 & 164 & 53.6 & 18.0 & 175 & 55.5 & 21.8 & 190 \\
\hline $209 \mathrm{JH}$ & 291258 & 171 & 61.5 & 25.6 & 195 & 61.3 & 25.0 & 230 \\
\hline 23310 & 291161 & 186 & 70.0 & 25.9 & 240 & - & - & - \\
\hline 3 & 2 & 173 & 55.5 & .9 & 18 & .6 & 19.5 & 180 \\
\hline
\end{tabular}




\begin{tabular}{|c|c|c|c|c|c|c|c|c|c|}
\hline 284 & $\mathrm{HD}$ & 190364 & 176 & 58.7 & 21.1 & 175 & - & - & - \\
\hline $332 \pi$ & $\mathrm{MH}$ & 040854 & 157 & 70.3 & 35.3 & 170 & - & - & - \\
\hline 344 & MS & 251262 & 165 & 59.5 & $25: 0$ & 178 & - & - & - \\
\hline 3450 & $\mathrm{CB}$ & 141047 & 161 & 59.0 & 25.5 & 160 & 59.0 & 24.1 & 185 \\
\hline 362 & VF & 131258 & 171 & 63.5 & 16.1 & 208 & - & - & - \\
\hline 364 & DR & 240863 & 178 & 63.0 & 24.7 & 225 & - & - & - \\
\hline $380 \mathrm{~N}$ & $\mathrm{MN}$ & 130461 & 165 & 57.0 & 24.4 & 205 & 57.0 & 24.4 & 205 \\
\hline 4281 & $N^{\prime}$ & 031042 & 165 & 53.5 & 21.8 & 175 & 54.0 & 21.3 & 185 \\
\hline 429 & AW & 140544 & 163 & 62.0 & 28.2 & 180 & 59.5 & 26.8 & 235 \\
\hline 502 & EK & 211044 & 168 & 66.0 & 30.8 & 150 & - & - & - \\
\hline 508 & CS & 250957 & 174 & 58.0 & 21.1 & 205 & - & - & - \\
\hline 509 & Cs & 141059 & 174 & 71.0 & 29.1 & 225 & - & - & - \\
\hline 510 & $\mathrm{HE}$ & 150557 & 173 & 66.5 & 25.0 & 225 & 62.6 & 23.8 & 210 \\
\hline 512 & DE & 010551 & 156 & 50.0 & 20.9 & 160 & 48.2 & 18.0 & 200 \\
\hline 520 & JJ & 200859 & 166 & 53.8 & 25.3 & 170 & - & - & - \\
\hline 523 & IB & 290559 & 170 & 63.0 & 25.3 & 225 & 61.0 & 23.1 & 210 \\
\hline 524 & $\mathrm{JP}$ & 160849 & 163 & 50.0 & 20.4 & 180 & 52.0 & 19.0 & 212 \\
\hline & \multicolumn{9}{|c|}{$\begin{aligned} & =\text { clay of birth } \\
& =\text { body helght }(\mathrm{cm})\end{aligned}$} \\
\hline$t$ & \multicolumn{9}{|c|}{$\begin{array}{l}=\text { body helght (cm) } \\
=\text { body welght }(\mathrm{kg})\end{array}$} \\
\hline$f$ & \multirow{2}{*}{\multicolumn{9}{|c|}{$\begin{array}{l}=\text { body fat (\%); determined by measur Ing } 4 \text { skinfolds (7) } \\
=\text { maximal workload (watt), attalned in a stepwlse Increas Ing } \\
\text { exerclse protocol using a blcycle ergometer (11) }\end{array}$}} \\
\hline & & & & & & & & & \\
\hline
\end{tabular}

In Table 2.3 mean values and standard deviations of age (at 1-1-1986), height, weight, \%fat and $W_{\mathrm{rn}}$ of the treadmill-test group (TG) and the field-test group (FG) are shown.

Table 2.3 Mean characterlstlcs of the volunteers at the start of the study and 2-3 weeks after the marathon

\begin{tabular}{|c|c|c|c|c|c|c|c|c|}
\hline & \multicolumn{4}{|c|}{ Males } & \multicolumn{4}{|c|}{ Fernales } \\
\hline & \multicolumn{2}{|c|}{ start } & \multicolumn{2}{|c|}{ marathon } & \multicolumn{2}{|c|}{ start } & \multicolumn{2}{|c|}{ marathon } \\
\hline & mean & sd & mean & sd & mean & sd & mean & sd \\
\hline \multicolumn{9}{|l|}{ TG } \\
\hline$\overline{\text { age }}$ (years) & 34 & 8 & - & $-\infty$ & 32 & 6 & $-\infty$ & $-\infty$ \\
\hline helght $(\mathrm{cm})$ & 178 & 5 & - & - & 169 & 7 & - & $\ldots$ \\
\hline welght $(\mathrm{kg})$ & 72.4 & 8.1 & 71.2 & 7.2 & 60.2 & 7.11 & 59.8 & 8.1 \\
\hline fat (\%) & 15.3 & 4.2 & 15.7 & 3.2 & 24.2 & 3.4 & 22.0 & 3.3 \\
\hline$w_{m}$ (watt) & 270 & 31 & 298 & 40 & 201 & 23 & 208 & 18 \\
\hline \multicolumn{9}{|l|}{ FG } \\
\hline$\overline{\text { age (years) }}$ & 35 & 8 & -- & -- & 32 & 7 & - & -- \\
\hline helght (om) & 179 & 6 & $-\infty$ & -- & 165 & 6 & $-\infty$ & $\ldots$ \\
\hline welght (kg) & 72.8 & 6.9 & 71.4 & 5.8 & 58.3 & 4.7 & 57.4 & 4.8 \\
\hline fat $(\%)$ & 15.7 & 4.8 & 15.8 & 4.5 & 24.4 & 4.1 & 24.1 & 3.6 \\
\hline$W_{m}$ (watt) & 264 & 37 & 299 & 36 & 179 & 19 & 204 & 21 \\
\hline
\end{tabular}




\section{Drop outs}

A number of participants were not able to finish the programme by running a marathon. Because the study lasted 18-20 months the drop-out reasons were of diverse nature. Injuries, a too heavy psychological load especially before contests, illness, removal, restricted leisure time because of more work and pregnancy were the most frequent reasons.

During the first period one of the males gave up due to injury and 6 stopped due to Illness, removal and lack of time or motivation. In the second period 1 male stopped due to change of job, 1 due to lack of motivation and 2 due to injuries. During the third period 12 males stopped, 5 because of injuries, 3 because of psychological pressure, 1 because of removal, and 3 for unknown reasons. For the females, 4 of the 5 drop-outs in the first period were caused by injuries. In the second period 1 stopped due to injury and 1 due to lack of motivation. During the last period the reason for dropping out was psychological pressure with or without injuries of the lower extremities in 3 of 6 cases, 1 because of a knee injury, 1 for pregnancy and 1 for unknown reason. During the first period some of the injuries developed because a number of subjects did not stand the light training adequately. In Fig. 2.4 a survey of the total amount of drop-outs as well as the number of participants of the contests per period is given.

Statistical analysis of the personal characteristics (body weight, \% fat and $W_{\text {max }}$ ) of the participants at the start of the study demonstrates no reason for a selective drop-out. Only the age of males and females demonstrates a significant difference. The mean age of the the marathon runners was $35.6 \pm 7.4$ year for males and $33.1 \pm 6.3$ year for females. The age of the drop-out group was $31.2 \pm 7.5$ year for males and $28.3 \pm 5.7$ year for females $(M: p=0.17$; $F: p=0.036)$.

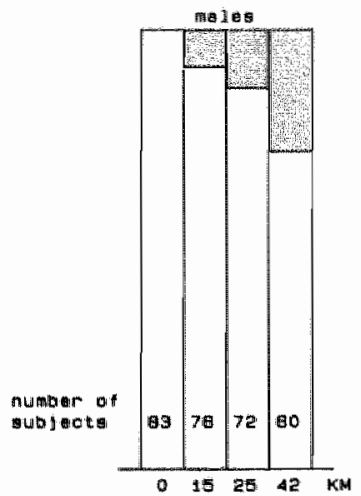

FIg. 2.4 Number of partllclpants in the contests and drop-outs durlng the tralning perlods.

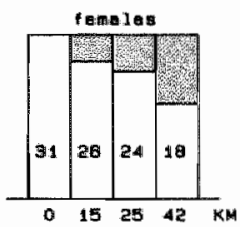




\section{Test performances}

Since it is impossible to test all the subjects on one morning and in order to make the results of the performance tests comparable to each other, the treadmill-tests and the field-tests were carried out at a fixed time of the day.

The volunteers of the treadmill group (TG) carried out their tests in the laboratory 3 days before each contest and 3 and 5 days after each contest (Fig. 2.2). Before starting the test, a teflon catheter (Quik-Cath, Travenol Laboratories, Ireland) was inserted into an anticubital vein. The horizontal running treadmill-test consisted of a warming up of $10 \mathrm{~min}$ at a rate of $10 \mathrm{~km} \cdot \mathrm{h}^{-1}$, then every 4 min the speed was increased with steps of $2 \mathrm{~km} \cdot \mathrm{h}^{-1}$. Before the warming up, during the last $0.5 \mathrm{~min}$ of each stage as well as at the end of the treadmill-test a blood sample $(1 \mathrm{ml})$ was taken to determine the lactate concentration. When drawing the blood the subject did not run. The treadmill-test ended at the moment the subject could not keep up with the imposed speed (maximum speed). The treadmill used was a model 18-60 Quinton instruments (Seattle, USA) with a top speed of $24 \mathrm{~km} \cdot \mathrm{h}^{-1}$. During the whole treadmill-test the heart rate (HR; min-1) was recorded using a Sporttester PE 3000 (Polar Electro ky, Finland). The lactate concentration (mmol..1-1) was determined using a lactate analyzer (Lactate Analyzer 640, Kontron, Zurich, Switzerland).

The performance test of the volunteers of the fleld-test group (FG) consisted of the following parts.

- A warming-up period of 25-30 min consisting of running at a very low pace (10-12 km.h-7), stretching exercises and some interval runs with increasing speed (max. 16-22 $\mathrm{km}^{-1} \mathrm{~h}^{-1}$ ) over a distance of $60-80 \mathrm{~m}$

- Interval running at maximal speed over a distance of 400 and $1000 \mathrm{~m}$ with a rest period of $15 \mathrm{~min}$ in between

- A cooling down period of $10 \mathrm{~min}$ and some stretching exercises. Throughout the field-test HR was recorded using a Sporttester PE 3000 (Polar Electro ky. Finland).

\section{Muscle biopsies}

The biopsies were taken from the $\mathrm{m}$. vastus lateralls (left and right leg, alternately), with a Bergström needle (diameter $5 \mathbf{m m}$, fa. Stôpler, S.A. Utrecht) according to the technique described by Evans (8). The muscle sample was divided into 3 pleces for biochemical analysis, for histochemical and histological analysis and for electronmicroscopy.

The muscle sample for blochemical analysis was frozen in liquild nitrogen and stored at $-80^{\circ} \mathrm{C}$ for subsequent processing. The muscle sample for histochemistry was mounted on a cork, frozen into liquid freon and the sample for electronmicroscopy was kept for at least $24 \mathrm{~h}$ at $+4 \circ \mathrm{C}$ in a glutaraldehyde solution $(2,5 \%$ glutaraldehyde and $4 \%$ sucrose in $0,1 \mathrm{M}$ sodiumphosphate buffer; $\mathrm{pH} 7.2-7.4)$. One to two days before and one day after the first and third biopsy, training was stopped in order to prevent complications and to attain standardized conditions. 


\section{Contests}

A similar protocol as preparation for each contest was invariably followed. During the last week before the contest there was only a light training in order to make the influence of the training on the tests as small as possible and to be able to start the contest fit. During the $15 \mathrm{~km}$ contest the subjects did not drink. During the 25 $\mathrm{km}$ contest most of the subjects drank 50-100 ml every $5 \mathrm{~km}$. The drink consisted of a mixture of orange juice, lemon juice and a vitamin syrup (sacharose concentration $10 \%$ ). During the marathon most of the subjects drank a $10 \%$ solution of Perform ${ }^{\mathbf{r}}$ (Fa Wander Ltd, Bern) every $5 \mathrm{~km}$. Besides, Just before the start of the marathon all subjects drank a drink prepared from 25 gram Performa dissolved in about $100 \mathrm{ml}$ of water. Pertorm contains $15 \%$ fructose and $85 \%$ maltodextrine.

During the $25 \mathrm{~km}$ contest and during the marathon the registration of HR was carried out with a Sporttester PE 3000 (Fa. Support BV, Almere).

\section{Variables measured}

As shown in the test protocol (Fig. 2.2) a number of blood samples was drawn in which blochemicall, hematological, histological, histochemical, cardilo-respiratory and performance variables were determined and measured. A summary of all determinations performed is given in Table 2.4

Table 2.4 Summary of measurements performed in each per lod before and after the 15,25 and $42 \mathrm{~km}$ contest

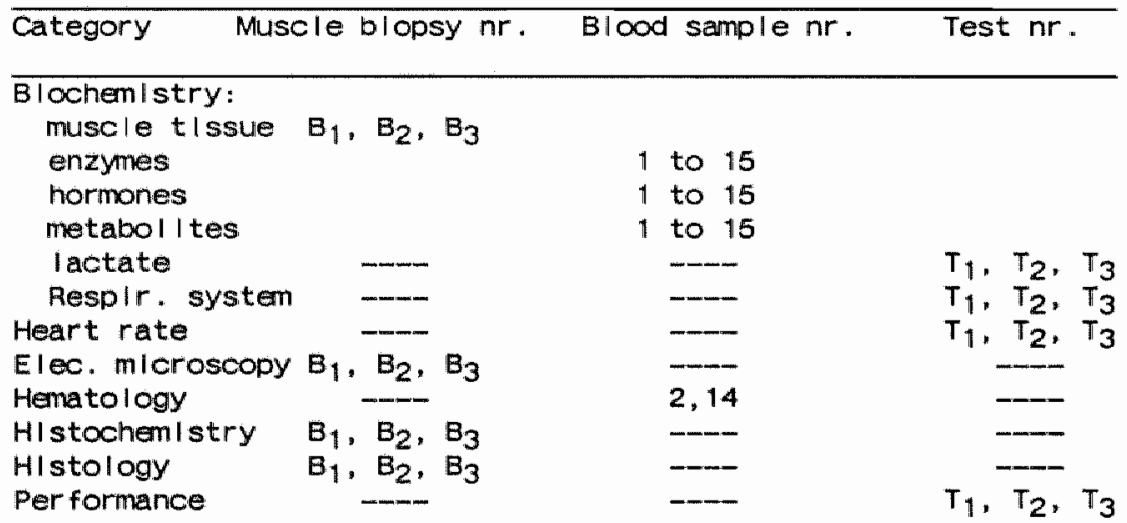

The numbers are those shown in FIg. 2.2 .

\section{Biochemistry}

Muscle tissue (Analytical assay)

The portion of the muscle biopsy to be used for blochemistry was dehydrated by the dry frozen technique (overnight at $-30^{\circ} \mathrm{C}$ ). 
Freeze-dried tissue was weighed (weight of the biopsies ranged from 3.0 to $18.8 \mathrm{mg}$ dry weight) and subsequently extracted at $-15^{\circ} \mathrm{C}$ in a mixture of perchloric acid (3.0 mol..$\left.^{-1}\right)$ and dithiothreitol (5 $\mu \mathrm{mmol.1-1}$. The extraction volume was adjusted to the dry welght of the tissue specimen, i.e. about $25 \mu \mathrm{l}$ per $\mathrm{mg}$ dry weight. After grinding of the tissue with a glass rod in the extraction fluid, the whole mixture was rapidly frozen in liquid nitrogen and thawed to a temperature of $4{ }^{\circ} \mathrm{C}$. After centrifugation at $4{ }^{\circ} \mathrm{C}$ with $1200 \mathrm{~g}$ for 5 min, an aliquot of the supernatant was removed and neutralized with $\mathrm{KHCO}_{3}$. The pellet was stored at $-20^{\circ} \mathrm{C}$ for subsequent determination of glycogen (see below).

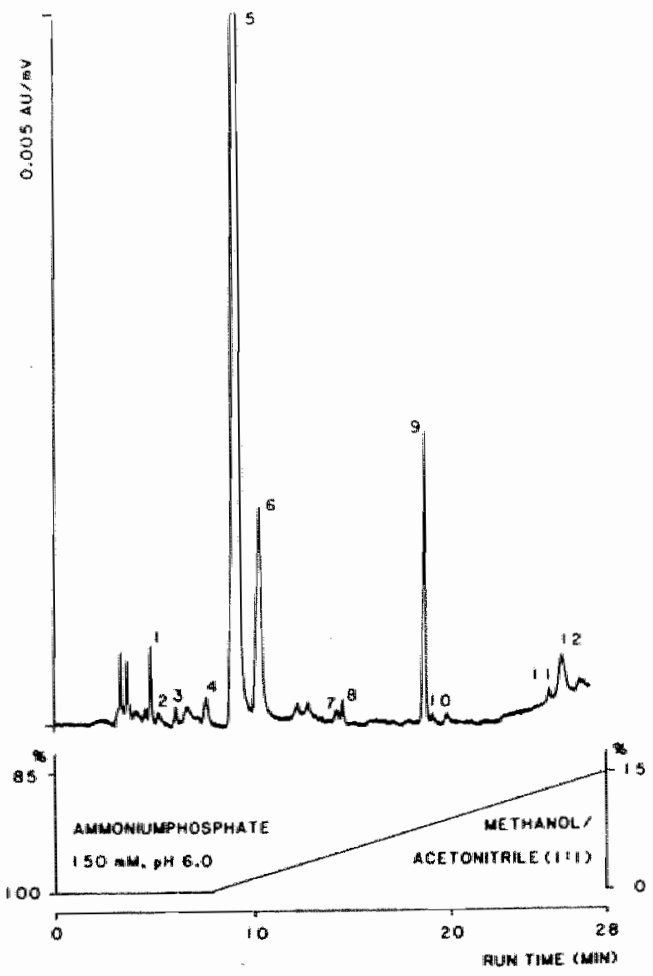

FIg 2.5 Chromatogram of a pre-contest musclie tissue specimen.

Typlcal HPLC chromatogram. The blopsy was taken from $m$. vastus lateralls during a pre-contest perlod. Dry welght of the tissue was $9.6 \mathrm{mg}$. Total volume after extraction and neutral Iza$t$ llon was $400 \mu \mathrm{l}$, from which $10 \mu l$ was used for HPLC analysis. In this example about 350 pmol NAD (peak9) was injected on collumn. The other peaks are GTP (peak number 1), GDP (2), GMP + urate (3), IMP (4), ATP (5), ADP (6), AMP (7). NADP (8), inosine (10), coenzyme A (11) and adenosilne (12). Peaks were visuallzed at $254 \mathrm{~mm}$. Sensitivity of the detection was set at $0.005 \mathrm{AuJ} / \mathrm{mV}$.

Total run time was $28 \mathrm{~m} / \mathrm{n}$. At the lower part the gradient of the elution flluld Is shown. Buffer A consisted of $\mathrm{NH}_{4}\left(\mathrm{H}_{2} \mathrm{PO}_{4}\right)(150 \mathrm{mM}$, $p H=6.00$ ), buffer $B$ was a mixture of acetonltr $\|$ ie and methanol $(1: 1$, by vo(ume). Peaks were detected at $254 \mathrm{~mm}$. LIChroCART 4-4 (Merck, Germany) was used as guard column. 
The neutralized supernatant was stored at $-80^{\circ} \mathrm{C}$ until further analysis. Tissue contents of guanosine triphosphate (GTP), guanosinne diphosphate (GDP), guanosine monophosphate (GMP), adenosine triphosphate (ATP), adenosine diphosphate (ADP), adenosine monophosphate (AMP), hypoxanthine (HX), xanthine $(\mathrm{X})$, b-nicotinamide adenine dinucleotide (NAD), inosine (I), co-enzym-A (COA), adenosine (A), inosine monophosphate (IMP) and energy charge $\left(E C=([A T P]+1 / 2[A D P]) \cdot([A T P]+[A D P]+[A M P])^{-7} ; \%\right)$ were determined by high pressure liquid chromatography (HPLC; Varian 5500). If not indicated otherwise the measured quantities are given in fumol.g- (dry weight). A modification of the method of Wynants and Van Belle (23) was used. In short, a small sample of the neutralized extract $(10 \mu \mathrm{l})$ was injected on a reversed phase column (Lichrosorb RP-18, Merck, Germany) and eluted by gradient ellution at a flow speed of $0.8 \mathrm{ml}$.min-t. Solvent $A$ was an aqueous buffer of $\mathrm{NH}_{4}\left(\mathrm{H}_{2} \mathrm{PO} \mathrm{C}_{4}(150 \mathrm{mM}, \mathrm{pH}=6.00)\right.$, whereas solvent $\mathrm{B}$ consisted of a $1: 1$ mixture (by volume) of acetronitrile and methanol. Fig. 2.5 shows a typical example of a chromatogram obtained with an extract of a pre-contest tissue specimen.

Creatine phosphate was measured fluorometrically (22). Lactate was assayed fluorometrically (17). The tissue content of inorganic phosphate was monitored using the spectrophotometric method (3). Glycogen content was assayed as glucose. To this end, the above mentloned precipitate was kept at $37 \circ \mathrm{C}$ for $3 \mathrm{~h}$ after addition of $1.0 \mathrm{ml} 1 \mathrm{M} \mathrm{NaOH}$. Subsequently $1.0 \mathrm{ml} 95 \%$ ethanol was added and the mixture was heated at $85^{\circ} \mathrm{C}$ for $10 \mathrm{~min}$. After coolling to $4 \circ \mathrm{C}$, the mixture was stored at this temperature for $24 \mathrm{~h}$. Thereafter, the mixture was centrifuged at $4{ }^{\circ} \mathrm{C}$ with $1100 \mathrm{~g}$ for $20 \mathrm{~min}$. The clear supernatant was carefully removed, and the residue was washed twice with $0.5 \mathrm{ml} 60 \%$ ethanol. After centrifugation at $4 \circ \mathrm{C}$ with $1100 \mathrm{~g}$ for $30 \mathrm{~min}$, the glycogen residue was hydrolyzed at $1000 \mathrm{C}$ for $3 \mathrm{~h}$ after addition of $1.0 \mathrm{ml} 1 \mathrm{M} \mathrm{HCl}$ to the residue. After neutrallzation of the mixture with $0.5 \mathrm{ml}$ Tris-KOH, the alliquots were used for the fluorometric assay of the glucose moleties (22). The fluorometric assays were performed on a Zelss ZFM4 Fluorometer (Zeiss, Germany) at $25^{\circ} \mathrm{C}$.

\section{Blood}

After drawing the blood it was immediately put on ice and then centrifuged at $2-4 \circ \mathrm{C}$ for $10 \mathrm{~min}$ at $3000 \mathrm{rpm}(1700-1800 \mathrm{~g})$.

The plasma was stored at $-70^{\circ} \mathrm{C}$ for subsequent processing.

\section{Metabolites}

Urea (mmol.l- $)$ was determined using an auto-analyzer (type II $\mathrm{C}$ plus, Technicon Instruments Corporation, Tarrytown, NY 10591) using the Diacetylmonoxin method (manifold PN 170-A003-02). Creatinin ( $\mu$ mol. $\left.\right|^{-1}$ ) was determined according to the method of Jaffa, also with the auto-analyzer, type II c plus (manifold PN 170A003-02). Albumin was determined spectrophotometrically (wave length $603 \mathrm{~nm}$ ) according to the broomcresol purple (BCP) method at a centrifugal analyzer (type Cobas Bio, Hoffmann La Roche, Mydrecht). 
Total protein (g.t-1) was determined using the biuret method and above mentioned equipment with a kit of Hoffman La Roche No 1010083.

Uric acid (mmol. $1^{-1}$ ) was determined according to the method of Haeckel using the enzymes uricase (E.C. 1.7.3.3), catalase (E.C. 1.11.1.6) and aldehydedehydrogenase (E.C. 1.2.1.3).

The long-term coefficients of analytical variance of the several metabolites are: albumin ( $\left.35 \mathrm{~g} . \mathrm{l}^{-1}\right) 2.0 \%$, total protein $\left(72 \mathrm{~g} . \mathrm{l}^{-1}\right)$ $1.2 \%$, urea (4.7 mmol.-7) $1.3 \%$ and $\left(11.5 \mathrm{mmol} .^{-1}\right) 1.0 \%$, creatinin (97 $\left.\mu \mathrm{mol} . \mathrm{I}^{-1}\right) \quad 1.0 \%$ and $\left(268\left(\mu \mathrm{mol}^{-1}\right) 1.0 \%\right.$ and uric acid $\left(0.21 \mathrm{mmol}^{-1} \mathrm{t}^{-1}\right)$ $3.8 \%$ and $\left(0.51 \mathrm{mmol}^{-1}\right) 3.1 \%$.

\section{Enzymes}

Creatine phosphokinase (CK; E.C. 2.7.3.2.), L-Aspartate aminotransferase (Asat; E.C. 2.6.1.1.) and L-Alanine aminotransferase (Alat; E.C. 2.6.1.2.) were determined according to methods of the Scandinavian Committee on Enzymes (SCE) at a centrifugal analyzer (type Cobas Bio). The kit Baker CK-BAC was used for the determination of CK; for Asat and Alat kits of Boehringer were used with the numbers 191337 and 191345 respectively. The activity of the enzymes was expressed in U.I-1.

The long-term coefficients of analytical variance of the several enzymes are: CK (177 U.I-1) $2 \%$ and (480 U.I-1) $1.5 \%$, Asat (46 U.1-1) $2 . \%$ and $(117$ U.1-1) $1.3 \%$ and Alat $(40$ U.I-1) $2.7 \%$ and (112 U.I-1) $1.6 \%$.

\section{Hormones}

Cortisol (Cor), testosterone (Tes) and dehydroeplandrosterone sulphate (DHEAS) were determined using a radio-Immuno-assay (RIA). The principle of the RIA is a competition reaction between the hormone in plasma and a known amount of radio-active labelled hormone on the one side and the specific antibody on the other side. After the incubation the bound fraction is separated from the free fraction. The number of desintegrations is a measure of the concentration of the hormone. For the hormone testosterone preliminary processing is necessary to extract the testosterone bound to the protein testosterone-Immuno-bounding-globulln (TIBG) with a mixture of hexane and ether.

The hormones were determined by means of commerclal kits (DPC; cortisol ( $\left.\mu \mathrm{mol} . \mathrm{I}^{-1}\right)$ with a C.A.C. Kit, DHEAS (mmol. $\left.\left.\right|^{-1}\right)$ with a TDKDS2 kit and testosterone (nmol..l-1) with a KTTD 1 kit). All hormone measurements were done in duplicate, whereas all samples of one subject were (if possible) assayed in the same run. The intra-assay coefficients of variation as calculated from the replicates were $4.5 \%$ for testosterone, $4.0 \%$ DHEAS and $5.1 \%$ cortisol. The long-term coeffliclents of analytical varlance of the several hormones are: cortisol (120 $\left.\mu \mathrm{mol}^{-1} \mathrm{I}^{-1}\right) 8.2 \%$, (480 $\left.\mu \mathrm{mol} . \mathrm{I}^{-1}\right)$ $3.8 \%$ and $(820 \mu \mathrm{mol} .1-1) 4.9 \%$, testosteron $\left(2.43 \mathrm{nmol}^{-1} \mathrm{I}^{-1}\right) 7.0 \%,(7.7$ nmol.1-1) $2.7 \%$ and (22.7 nmol. ${ }^{-1}$ ) $2.3 \%$ and DHEAS ( $4.1 \mathrm{mmol} . \mathrm{l}^{-1}$ ) $10.0 \%$, $(6.0 \mathrm{mmol.} .1-1) 8.1 \%$ and $\left(20.2 \mathrm{mmol}^{-1-1}\right) 8.9 \%$. 


\section{Lactate}

Lactate concentration (mmol. $\mathrm{I}^{-7}$ ) was determined in plasma using a lactate analyzer (Lactate Analyzer 640, Kontron, Zurich,

Switzerland).

Heart rate

During the treadmill-tests and the field-tests the heart rate (HR; min-7) was recorded using a Sporttester PE 3000 (Polar Electro Ky, Finland). Besides the heart rate (Sporttester PE 3000) was determined during the contests of the 25 and $42 \mathrm{~km}$.

\section{Electronmicroscopy}

A portion of the muscle biopsies was washed with a solution of a 0.1 $M$ phosphate buffer ( $\mathrm{pH}=7.4$ ) after storage in a solution of glutaraldehyde (see p. 29). Subsequently the samples were fixed in a $1 \%$ osmlum-tetraoxide solution in $0.1 \mathrm{M}$ phosphate butfer. The pieces of tissue were dehydrated step by step by washing in solutions of increasing concentration ethanol and then mounted in Epon 812 (12). Ultra thin sectlons $(1 \mu \mathrm{m})$ were stained with toluidine blue for light microscopy. Ultimately they were cut $(50-80 \mathrm{~nm})$ with a diamond knife at a Reichert-Ultracut (Lameris, Utrecht) and caught on grids of platinum. The sections were contrasted in uranyl acetate and lead citrate. Finally the sections were examined and photographed using a Philips EM 400 electronmicroscope.

\section{Hematology}

The following variables were measured. The number of leukocytes (WBC, $\left.10^{\circ} .1^{-1}\right)$, and the subpopulation of the leukocytes $\left(10^{\circ} .1^{-1}\right)$ such as neutrophils, lymphocytes, monocytes, eosinophils and basophils, the number of erythrocytes (RBC, 1012.1-1), hemoglobin ( $\mathrm{Hb}, \mathrm{mmol.} \mathrm{I}^{-1}$ ), hematocrit ( $\mathrm{Ht}, \mathrm{I}_{\mathrm{I}} \mathrm{I}^{-1}$ ), indices of the erythrocytes $\mathrm{MCV}$ (fi), $\mathrm{MCH}$ (fmol) and MCHC (mmol.1- $)$, distribution of the diameters of the erythrocytes (ADW, \%), the number of thrombocytes (PLT, 10\%.1-1), mean volume of thrombocytes (MPV, fl), distribution of the diameters of the thrombocytes (PDW, \%), relative volume of the thrombocytes (PCT, I.1-1), leukocytes with a larger activity of peroxydase (HPX, \%) and ferritin ( $\left.\mu \mathrm{g.t} \mathrm{I}^{-1}\right)$. Most of the determinations were done with an automated analyzer (H.6000, Technicon Instruments Corporation, Tarrytour, New York, U.S.A.). Ferritin was determined using a kit (code 190-2001, Blo-RAD).

The long-term coefficients of analytical variance of the several varlables of the red cell system are: erythrocytes $3.8 \%, \mathrm{Hb} 3.6 \%, \mathrm{Ht}$ $3.7 \%$, MCV $1.6 \%$, MCH 3.4\%, MCHC 3.5\%, RDW $2.1 \%$ and ferritin concentration between $7-11 \mu \mathrm{g} . \mathrm{I}^{-1} 10 \%$ and between $11-450 \mu \mathrm{g} .1-15 \%$. The coefficient of analytical variance values of the several variables of the white cell system are: leukocytes $7.9 \%$, neutrophils $2.0 \%$, Iymphocytes $2.3 \%$, monocytes $7.8 \%$, eosinophils $8.6 \%$, basophils $11.3 \%$ and HPX $28.1 \%$. The values for the platelet system are: thrombocytes $8.1 \%$, MPV $3.8 \%$, PDW $4.0 \%$ and PCT $6.9 \%$. 
Histology and histochemistry

A plece of muscle tissue (25-50 mg) was mounted on a cork, (the longitudinal axis of the muscle fibers vertical to the surface of the cork). The tissue was fixed to the cork (diameter $2.4 \mathrm{~cm}$, thickness $3 \mathrm{~mm}$ ) with Tissue-Tek (Miles Scientific). After that the cork with tissue was held in a solution of 2-methylbutan, cooled by liquild nitrogen. The frozen tissue was stored in a small aluminium box (diameter $3 \mathrm{~cm}$, height $3 \mathrm{~cm}$, Sanbio B.V.,Uden) at $-80^{\circ} \mathrm{C}$.

The muscle tissue was cut in a cryostate (type cryocut II microtome, Reichert Jung) at a temperature of -15 to $-20 \circ \mathrm{C}$. The sections were $10 \mu \mathrm{m}$ thick and mounted on glass. After air drying at room temperature the sections were stored in boxes at $-20 \circ \mathrm{C}$. Before staining the sections were brought at room temperature and air dried (about $30 \mathrm{~min}$ ). From a series of closely together lying sections 3 were stained with haematoxilin-eosin (HE), 3 with perlodic acid Schiff's stain (PAS), and 6 with ATP-ase (prelncubation at $\mathrm{pH}=4.3$ or $\mathrm{pH}=4.6$ ) (6).

The $\mathrm{He}$ stained sections were examined for pathological changes. In the ATP-ase stained sections, the fiber diameter of type I and type II was measured (6) using an interactive graphic digitizer (MOP. videoplan, Kontron). The amount of glycogen in muscle fibers was estimated from the PAS stain. According to the intensity of the PAS stain the fibers were classiffed as negative, light, moderate or heavy which were considered as heavily, moderately, lightly, or not depleted. By comparing sections stained with HE, PAS, and ATP-ase respectively, conclusions were drawn about relationships between pathological changes, glycogen depletion and muscle flber types.

\section{Performance}

As a measure for the running capacity of the field-test (FT) group the average running speed $\left(\mathrm{v} ; \mathrm{m} . \mathrm{s}^{-1}\right)$ over distances of 400 and 1000 $\mathrm{m}$ was calculated from the distance and the time measured. For the treadmIII (TG) group $V_{\text {max }}\left(m_{.} s^{-1}\right)$ was taken as a measure for running capacity. If the subjects could not maintain the treadmill speed during the whole $3.5 \mathrm{~min}$, the maximum speed was calculated using the equation

$$
V_{\text {max }}=V_{n-1}+0.56 T_{r} / 210
$$

in which $V_{n-1}\left(m . s^{-1}\right)$ is the treadmill speed at the last but one loadingstep and $T_{n} / 210$ is the fraction on the treadmill during the last exercise step and 0.56 the increase in velocity $\left(\mathrm{m} . \mathrm{s}^{-1}\right)$ for each exercise stage.

In order to have a measure for the intensity in which the contests were run, the following intensity indices were calculated using the equation 


$$
\text { SII }=V_{c .}\left(V_{T_{1}}\right)^{-1.100}
$$

in which SII (\%) is the speed intensity index, $V_{c}$ the average speed (m.s-1) during the contest and $V_{T+1}$ is the average speed (m.s-1) during the field test $\left(T_{1}\right)$ before the contest (for the FT group). For the TG group $V_{T+1}$ corresponds with $V_{\max }$ of the test $\left(T_{1}\right)$ before the contest. A heart intensity index ( $\mathrm{HIl} ; \%)$ was calculated using the equation

$$
H I I=H_{0} \cdot\left(H_{T}\right)^{-1} .100
$$

In which $H_{0}$ is the average heart rate during the contests and $H_{T}$ the maximum HR reached during one of the field tests or treadmill tests.

\section{Statistical methods used in the marathon study}

In order to recognize a possible disturbance in balance between physical stress and physical stress tolerance the study consisted of four monographs

1) cardio-respiratory system and performance

2) catabolic and anabolic changes associated with endurance exercise

3) biochemistry and morphology of skeletal muscle

4) hematology (the hematological aspects in the study were used more preventively for the volunteers).

In all the monographs the same statistical techniques were used. In addition, for the hematological study a method was used to calculate the intra-individual varlations and critical differences.

This paragraph is organized as follows. Firstly the so-called boxand-whisker plots are described. Secondly a survey will be given of the nonparametric tests and finally an outline will be described of the method of assessing the intra-individual variations and critical differences.

Box-and-whisker plots

To describe (one dimensional) data one usually calculates the mean, standard devlation (s.d.) and other elementary characteristics. As a visual display histograms are commonly used. In the late seventies a new wave to represent data was introduced by Tukey. In his book simple but powerful techniques were described for exploratory data analysis (19). One of these methods is the box-and-whisker plot. The more advanced form of this plot is the schematic and notched box plot (15). For a simple box-and-whisker plot five values from a set of data are sufficlent: the extremes, the flrst and third quartiles and the median. In Fig 2.6 an example is given. The line dividing the box represents the medlan, the edges of the box the quartlles and the edges of the whiskers the extremes. The first modification is to identify the outllers. Tukey (19) distinguishes two types of outliers, namely outside values (denoted by 0 ) and far out 
values (denoted by *). Roughly speaking, for normally distributed values the difference between the two types is that the far out values fall outside the $99.999 \%$ range and the outside values are between the $99.3 \%$ and $99.999 \%$ range (19). To compare batches that are significantly different from each other or from some standard batch the so-called notched boxplot was introduced by McGill et al. (15). They show one way to use regions of overlap or non-overlap of special intervals around each median of a boxplot. The ends of these intervals are marked by putting a notch in the side of the central box. For approximately normally distributed variables these notches indicate the $95 \%$ confidence intervall of the median. In Fig. 2.7 the schematic and notched boxplot is Illustrated. Note that in this figure the vertical axis is not linear.

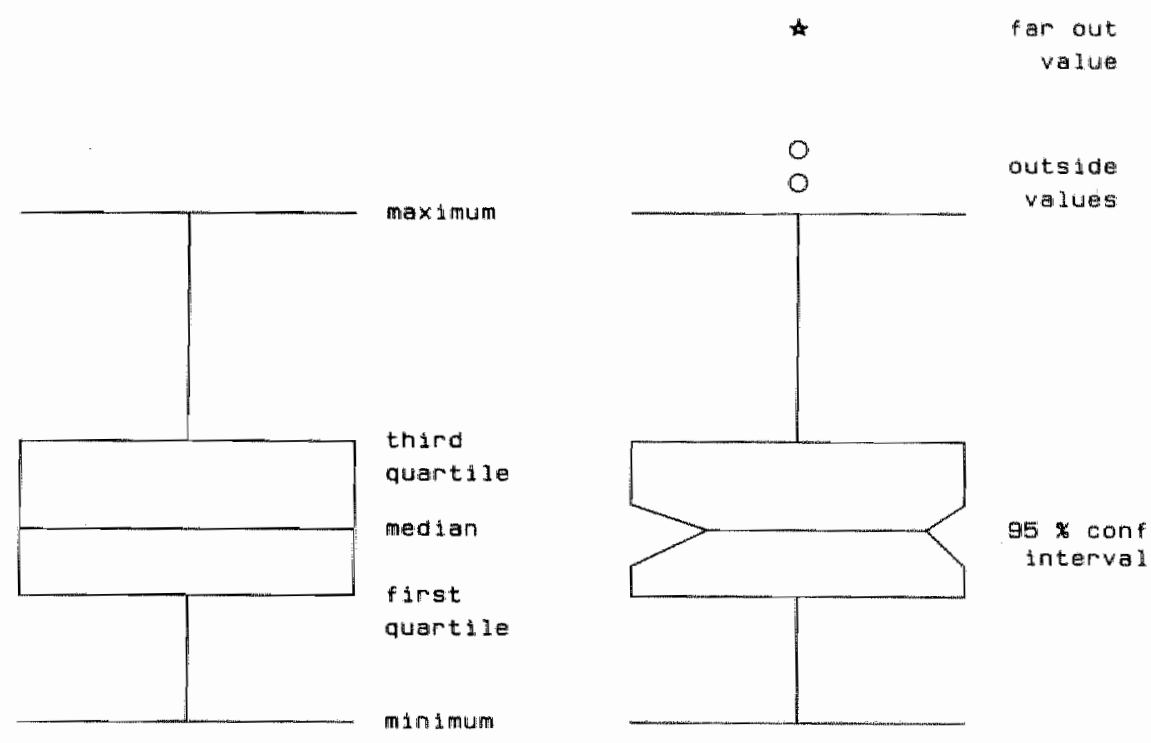

FIg. 2.6 Example of a simple box-and-whisker plot

Flg. 2.7 Example of a schema* lc and notched boxpllot

The computer programmes which were used to obtain the results were written in Fortran-77 for a VAX $11 / 780$ or VAX 8600 computer. The graphical facilities were obtained by using "Plot-10" and "Advanced Graphics" (Tektronix-software).

In Chapter 5 part 3 the boxplots are used to indicate the differences between the measurements of mean resting values and the first 4 plasma samples after each contest.

Non-parametric tests

Methods based on rankings form a substantial body of statistical techniques that provide alternatives to the classical parametric methods. The feature of non-parametric methods mainiy responsible 
for their great popularity is the weak set of assumptions required for their valldity. Although it was bellieved at first that a price in loss of efficiency would have to be paid for this robustness, it turned out, that the efficlency holds quite well under the classical assumption of normality and that these procedures may have considerable advantages in efficiency (as well as validity) when the assumption of normality is not satisfied (1).

In this study males and females are compared by means of the Mann-Whitney test (or equivalently the Wilcoxon two-sample test).

The same test was used to compare the treadmill group (TG) and the field test group (FG).

For the pairwise comparison of the repeated measurements for the males or the females we used the Wilcoxon one-sample (signed ranking) test. An overall test can be obtained by using the Bonferroni inequality; in the case of 3 pairwise comparisons an overall $5 \%$ significance test can be obtained by pairwise testing with significance level $1.67 \%$ (16). In Chapter 5.3 the test

performances before and after each contest were compared. The data of the two ratios $\left(T_{2} \cdot T_{1}{ }^{-1}\right)$ and $\left(T_{3} \cdot T_{1}{ }^{-11}\right)$ after each contest were arranged in a table analyzed with the McNemar's test (1).

Correlations were studled using the Spearman rank correlation test.

All the mentioned tests can be found in Armitage (1). In this book a description can also be found about regression analysis, which was used in Chapter 5.3 (1).

All the calculations were performed by using the statistical computer programme SPSS(X).

Intra-individual varlations and critical differences

During the marathon study a number of blood samples were taken from all participants. In Chapter 6.1 to Chapter 6.3 the hematological parameters were studied by means of the intra-individual variations and critical differences, among others. This was done following the procedures of Costongs (4). After analysis of the laboratory samples it was possible to calculate from each person the mean and varlance. Generally speaking this total varlance is composed of blological, analytical and "other" varlances (18), In the study of the hematological parameters speclal attention was paid to the blologlcal variance. The so-called "other" variance is mainly dependent on the blood collection which was reduced by the use of a standardized procedure (p. 21-22). This varlance component was therefore negligible for our purposes. The way of calculating the analytical variance was described by Costongs (5). Hence the biological variance can be computed by substracting the analytical varlance from the totall variance. In general clinical laboratory practice it is simpler and more common to use the coefficient of variation, denoted by $\mathrm{CV}$ instead of variances. The $\mathrm{CV}$ equals the quotient of the standard deviation and the mean. A percentage is obtained by multiplying this quantity with $100 \%$. The variability of these intra-individual CV's can be described in trequency tables. From these frequencies the 90-percentile value $\left(\mathrm{CV}_{\mathrm{poo}}\right)$ of the observed Intra-individuall CV's for every parameter has been determined. 
The critical difference has been developed as a tool to follow the course of one laboratory parameter in one individual in consecutive measurements. The critical difference is dependent on the total variance or equivalently on the total $\mathrm{CV}\left(=\mathrm{CV}_{T}\right)$ for the one individual concerned. Van Steirteghem et al. proposed to consider for the critical difference twice the standard deviation of the difference of two observations (20). This quantity denoted by $d_{k}$ can instead of units also be expressed in percentages by $2(2)^{1 / 4} . \mathrm{CV}_{\mathrm{r}}$. From the frequencies of $d_{k}$ we can also calculate the 50-percentile value $\left(\mathrm{d}_{\mathrm{kso}}\right)$ and the 90-percentile value ( $\mathrm{d}_{\mathrm{koo}}$ ). Finally we note that as an indicator of the variability of the studied parameters the percentage of the variable individuals in the group per parameter was calculated. This quantity (denoted by Nvar) was obtained by calculating the percentage of individuals for which the total variance was greater than the analytical variance (or equivalently the total CV was greater than the analytical CV). A Fortran-programme was written to perform the calculations.

\section{References}

1 Armitage P.: Statistical Methods in Medical Research Blackwell, Oxford, 1971.

2 Bauersfeld Karl-Heinz und Gerd Schroeter (eds): Grundlagen der Leichtathletik. Sportverlag Berlin,1979.

3 Belle van H.: New and sensitive reaction for automatic determination of inorganic phosphate and its application to serum. Anal Biochem 33:132-142,1970.

4 Costongs G.M.P.J.: Intra-individual variations and critical differences of clinical laboratory parameters. Ph.D. thesis, University of Limburg, Maastricht, 1984.

5 Costongs G.M.P.J., Janson P.C.W., Bas B.M., Hermans J., Brombacher P.J., Wersch van J.W.J.: Short-term and longterm intra-Individual variations and critical differences of haematological laboratory parameters. J Clin Chem Clin Bio 23:69-76, 1985.

6 Dubowitz Victor: Muscle Blopsy. A practical Approach II Edition, Baillière Tindall, 1985.

7 Durnin J.V.G.A., Womersley J.: Body fat assessed from total body density and its estimation from skinfold thickness: measurements on $\mathbf{4 8 1}$ men and women aged from 16 to 72 years. Brit J Nutr 32:77-97,1974.

8 Evans W.J., Pinney S.D., Young V.R.: Suction applied to a muscle biopsy maximizes sample size. Med Sports Exercise 14(1):101-102,1982.

9 Fox Edward L.: Sports physiology. Saunders College Philadelphia, 1979.

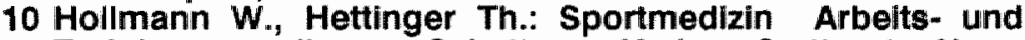
Trainingsgrundlagen. Schattauer Verlag, Stuttgart New York, 1980.

11 Kuipers H., Ph.D. thesis: Variability of physiological responses to exercise. Uitgeveri] de Vrleseborch, Haarlem, 1983. 
12 Luft $H .:$ Improvement in epoxy embedding methods. J Biophys Blochem Cytol 9:409-414,1961.

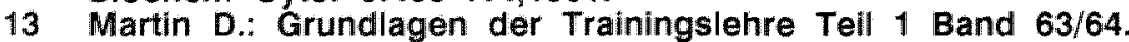
Verlag Karl Hofmann, Schorndorf, 1979.

14 Martin D.: Grundlagen der Trainingslehre Tell 2 Band 77/78. Verlag Karl Hotmann, Schorndorf, 1980.

15 McGill R., Tukey J.W., Larsen W.A.: Variations of box pllots. The American Statistician. 32:12-16,1978.

16 Miller R.G.: Simultaneous Statistical Inference. Second edition, Springer, New York, 1981.

17 Passoneau J.V: Lactate. Fluoremetric method. In: H.U. Bergmeyer: Methods of enzymatic analysis Academic Press, New York, pp 1468-1472,1974.

18 Stamm D.: Control of analytical variation in the production of reference values, in Grüsbeck R. and Alström T. (eds.): Reterence values in laboratory medicine. Wiley, New York, pp 109-126,1981.

19 Tukey J.W.: Exploratory Data Analysis. Addison-Wesley, Reading, 1977.

20 Van Steirteghem A.C., Robertson E.A., Young D.S.: Variance components of serum constituents in healthy individuals. Clin Chem 24:212-222, 1978.

21 Viru A.: The mechanism of training effects: a hypothesis. lint J Sport Med 5:219-227,1984.

22 Van der Vusse G.J., Coumans W.A., Van der Veen F.H., Drake A., Flameng W., Suy R.: ATP, creatine phosphate and glycogen content in human myocardial biopsies: markers for the efflcacy of cardioprotection during aortacoronary bypass surgery. Vasc Surg 18:127-134,1984.

23 Wijnants J., Belle van $H .:$ Single-run high performance liquid chromatography of nucleotides, nucleosides and major purine bases and its application to different tissue extracts Anal Biochem 144:258-266,1985. 
Chapter 3 Effects of endurance training and competition on exercise tests in relatively untrained people

\section{Introduction}

Running for various personal motives has become an integrated part of the life-style of many individuals today. Running a marathon once is the ultimate goal as might be concluded from the enormous numbers of participants in public marathon contests. However, the physical stress of a marathon training programme is so high that many people get problems before achieving their goal, if they do. Therefore guidance by an experienced trainer and/or physician is not a luxus but rather a need. However, authorized institutions with professional experts are hardly present in the network of health care or sports organizations in The Netherlands. One factor that might hinder or delay this development is the lack of a common body of knowledge. A great number of studies dealing with marathon running are focussing on performance determining factors like maximum aerobic power, anaerobic threshold or running economy (1, $2,11,12,13,14,15)$. The subjects were well-trained and in most cases belonged to the elite group of marathon runners. The prime aim of the present study was therefore to collect data of a population of untrained people throughout their training process to a marathon. Laboratory and field-tests were applied to question the usefulness of both types of testing in sport practice. Another aim of this investigation was to study the effect of three contests of different distances $(15,25$ and $42 \mathrm{~km})$ concluding the respective training periods on exercise performance, heart rate and plasma lactate concentration in exercise tests (Fig 3.1.). As the level of exertion during such a contest is much higher than that during the training the recovery processes of the body need extra time to achileve the pre-race status. Incomplete recovery of one or more relevant physiologic systems might be reflected in a decrease of the level of performance as tested in a progressive treadmill protocol or In a fleld-test. In competitive distance running it is an empirlcal findling that the recovery period needed to compete successfully in the next contest is longer as the distance or the running time increases. Most of the elite marathon runners participate only in 3 or 4 marathons per year. In the present study the results of exercise tests 3 and 5 days after the respective contests could be compared with those of a control test 3 days before the contests.

\section{Materials and methods}

\section{Subjects}

114 persons were non-selectedly chosen from a group of 265 candidates that met the following criterla. 
- Minimum age 20 years

- Maximum running distance $25 \mathrm{~km}$ per week

- Maximum number of training sessions three per week.

The subjects were divided into 2 groups: 25 males and 11 females participating in treadmill testing (Treadmill Group $=$ TG) and 57 males and 21 females running the fleld-tests (Field-test group = FG). $T_{1}, T_{2}$ and $T_{3}$ represent the physical exercise tests before and after the 15,25 and $42 \mathrm{~km}$ contest.

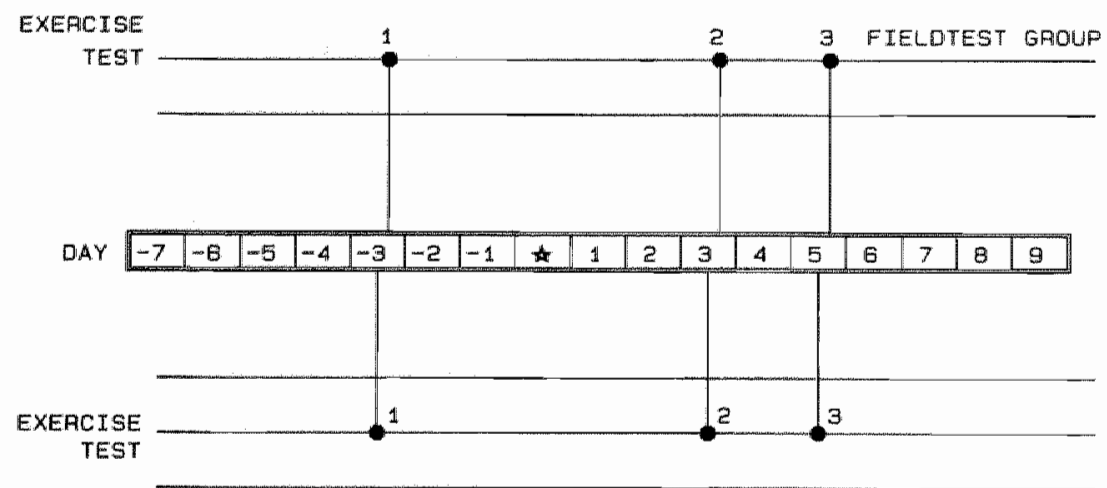

TREADMILL GROUP

Fig. 3.1 Time schedule of the protocol before and after the three contests with speclal reference to time Intervals for physlical exerclse tests 1,2 and 3 .

Prior to the start of the training programme and after the completion of the marathon contest the subjects underwent a medlcal examination including a progressive bicycle ergometer test. The most relevant findings are shown in Table 2.2. 60 males and 18 females completed the whole programme. Fig. 2.4 on p. 28 gives a survey of the 36 drop-outs during the study.

\section{Design}

The training programme was divided into three periods of 5 to 7 months. The weekly dlstance was gradually increased to a maximum of $45 \mathrm{~km}$ in the first period, $70 \mathrm{~km}$ in the middle and $110 \mathrm{~km}$ in the final one. Each training period was concluded with a contest over 15, 25 and $42 \mathrm{~km}$ (marathon), respectively. The relative contribution of different speeds in a training run (from endurance to sprint) was kept nearly constant throughout the training periods (Fig. 2.3).

Three days before each contest a maximal exercise test was carried out to study the training effects in the three periods. Three and five days after the performance contest the same test was repeated to study the effects of exhaustive endurance exercise on maximal physical working capacity. 25 males and 11 females participated in the treadmill-tests in the laboratory and the rest, 57 males and 21 females, performed field-tests on a track (Chapter $2 ;$ p. 29). 
Performance Indicators

In a progressive exercise test the decision of the subject to give up the exertion due to fatigue could be taken at any moment during the protocol. Therefore test velocity $V_{t}\left(m . s^{-1}\right)$ was calculated using equation 2.1 (p. 35). The performance in the field-test was expressed by the sum of both distances $(1400 \mathrm{~m})$ divided by the sum of the running times. The contest pertormance was expressed as index (SII) of the mean running velocity during the contest divided by the exercise test velocity multiplied with $100 \%$ (equation 2.2 on p. 36). A similar index was used as indicator for the heart rate (HII): mean heart rate during the contest divided by the maximum heart rate in the exercise test multiplied with $100 \%$ (equation 2.3 on p. 36). The speed lactate index (SLI) is the quotient of velocity at 4 mmol.I-1 [Lac-] in $T_{1}$ before each contest and the mean velocity of the contest multiplied with $100 \%$. The heart rate lactate index (HLI) is quotient of heart rate at $4 \mathrm{mmol}^{-l^{-4}}$ [Lac-] in $T_{1}$ before each contest and the mean heart rate during the contest multiplled with $100 \%$.

\section{Results}

The results are presented in four parts: training effects, contest performances, and relationship between exercise test, performance contest and prediction of performance in long distance runs.

\section{Training effects}

The major difference between the three training perlods is the amount of running kilometers that had to be accomplished. The effects of the training status on performance, heart rate and plasma lactate concentration in the progressive treadmill-tests are shown in Table 3.1.

Test performance of $T_{1}$ in the 3 training periods was $4.78 \pm 0.38$, $4.75 \pm 0.37$ and $4.70 \pm 0.33 \mathrm{~m} . \mathrm{s}^{-1}$ for the males and $4.17 \pm 0.24,4.20 \pm 0.23$ and $4.17 \pm 0.37 \mathrm{m.s}-1$ for the females, respectively. The differences were not statistically significant in both sexes.

Heart rate appeared to be significantly lower in the first training period compared to the other ones at submaximal as well as at maximal running velocity in both sexes. Plasma lactate concentration [Lac-] showed a declining tendency from the first to the third training phase both at submaximal and maximal running velocitles in males and females (Table 3.1). However, in males the running speed at $4 \mathrm{mmol}^{-1} \mathrm{I}^{-1}$ [Lac-] $\left(\mathrm{V}_{1}\right)$ was significantly higher in perlod 3 $\left(3.88 \pm 0.33 \mathrm{~m} . \mathrm{s}^{-1}\right)$ compared to perlod $1\left(3.54 \pm 0.44 \mathrm{~m} . \mathrm{s}^{-1}\right)$ and perlod 2 $\left(3.61 \pm 0.44 \mathrm{m.s}^{-1}\right)$ and also for perlod $3(3.41 \pm 0.32 \mathrm{m.s}-1)$ compared to period $1\left(3.23 \pm 0.35{\left.\mathrm{~m} . \mathrm{s}^{-1}\right)}^{-1}\right.$ in the females. Heart rate at $4 \mathrm{mmol} . \mathrm{I}^{-1}$ [Lac-] $\left(\mathrm{H}_{1}\right)$ increased significantly from perlod 1 to 2 and from 2 to 3 in the males and from period 1 to 2 in the females. The maximal heart rate also tended to increase from perlod 1 to perlod 2 and 3 but it was only significant in the females. Maximal [Lac-] decreased from period 1 to 3 : from $13.5 \pm 2.6$ to $11.2 \pm 2.1$ mmol.l-7 $(p<0.001)$ in males and from $11.2 \pm 1.9$ to $9.6 \pm 2.7$ mmol.t-1 $^{\prime}(p<0.05)$ in temales. 
Regarding the changes of the personal characteristics it appeared (Table 2.3 ; p. 27 ) that in males only $W_{\max }$ had increased significantly due to the training $(p<0.0001)$. In females $W_{\max }$ had increased and $\%$ fat had decreased significantly $(p=0.008$ and $p=0.05)$.

Table 3.1 Effect of the Increased training status from perlod 1 $(15 \mathrm{~km})$ to $2(25 \mathrm{~km})$ and $3(42 \mathrm{~km})$ on running veloclty, heart rate and plasma lactate concentration for the treacm l I group and fleldtest group

\begin{tabular}{|c|c|c|c|c|c|c|}
\hline & & & & & & \\
\hline & $\begin{array}{c}\text { perlod } \\
T_{1}\end{array}$ & $\begin{array}{l}\text { Males } \\
\text { perlod } 2 \\
\qquad T_{1}\end{array}$ & $\begin{array}{c}\text { perlod } 3 \\
T_{1}\end{array}$ & $\begin{array}{c}\text { perlod } 1 \\
T_{1}\end{array}$ & $\begin{array}{c}\text { mer lod } \\
\text { per } \\
T_{1}\end{array}$ & $\begin{array}{c}\text { per lod } 3 \\
T_{1}\end{array}$ \\
\hline & 0.38 & 37 & 0.33 & $4.17 \pm 0.24$ & 0.23 & \\
\hline$H_{m}$ & $182 \pm 8$ & 18 & $185 \pm 8$ & $182 \pm 7$ & & \\
\hline $4 m$ & $13.5 \pm 2.6$ & $\therefore 12.0 \pm 2.2$ & $11.2 \pm 2.1$ & $11.2 \pm 1.9$ & & \\
\hline$v_{1}$ & $3.54 \pm 0.44$ & 3.6 & $3.88 \pm 0.33$ & $3.23 \pm 0.35$ & \pm 0.16 & $3.41 \pm 0.32$ \\
\hline & $156 \pm 16$ & $164 \pm 10$ & $169 \pm B$ & $159 \pm 18$ & $173 \pm 12$ & $174 \pm 9$ \\
\hline
\end{tabular}

Mean values \pm so

$V_{m}\left(m \cdot s^{-1}\right)$ maximal velocity during the treadml $\mid$-test (TG)

$H_{m}\left(m \mid n^{-1}\right)$ max Imal heart rate dur $\|$ ing the test

$L_{m}$ (mol $\left.1^{-1}\right)$ maximal plasma lactate concentration during the test

$v_{1}\left(\mathrm{~m} . \mathrm{s}^{-1}\right)=\|$ intrapolated veloclty at $4 \mathrm{mmol} . \mathrm{l}^{-1}\left[\mathrm{Lac}^{-}\right]$

$H_{1}\left(\mathrm{mln}^{-1}\right)=\| n t r a p o l a t e d$ heart rate at $4 \mathrm{mmol} .1^{-1}\left[\mathrm{Lac}^{-}\right]$

The p-Values of the two-way wilcoxon test between the combinatlons

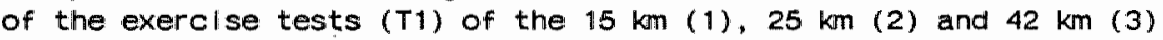
contests for males and females ( $p>0.05=$ not slgniflcant).

\begin{tabular}{lcccccc} 
& $1 / 2$ & $1 / 3$ & $2 / 3$ & $1 / 2$ & $1 / 3$ & $2 / 3$ \\
\hline$v_{m}$ & $n s$ & $n s i$ & $n s$ & $n s$ & $n s$ & $n s$ \\
$H_{m}$ & $n s$ & $n s$ & $n s$ & 0.005 & 0.012 & $n s$ \\
$L_{m}$ & $n s$ & 0.001 & 0.048 & $n s$ & 0.050 & $n s$ \\
$v_{1}$ & $n s$ & 0.021 & 0.034 & 0.022 & 0.012 & $n s$ \\
$H_{1}$ & 0.021 & 0.003 & 0.030 & 0.034 & 0.006 & $n s$
\end{tabular}

\section{Malles Fenales}

perlod 1 perlod 2 perlod 3 perlod 1 perlod 2 perlod 3

\begin{tabular}{ccccccc}
\hline Vft & $4.99 \pm 0.30$ & $5.11 \pm 0.34^{*}$ & $5.03 \pm 0.25$ & $4.10 \pm 0.26$ & $4.18 \pm 0.25$ & $4.13 \pm 0.29$ \\
$\mathrm{Hm}$ & $\mathrm{mm}$ & $185 \pm 8$ & $185 \pm 8$ & $\mathrm{~mm}$ & $189 \pm 8$ & $191 \pm 9$
\end{tabular}

Mean values \pm sd

* $0<0.05$ compared to perliod 1 and 3

it $m\left(m n^{-1}\right)=$ maximal heart rate dur ing the test

nom not measured

$V_{8 t}=$ mean velocity over the $400 \mathrm{~m}$ and $1000 \mathrm{~m}$ distance (FT) 
The performance in the field-test group (FG) did not show statistically significant differences between the three training periods in the femalles, but in the males the mean running velocity in period $2(5.11 \pm 0.34 \mathrm{m.s}-x)$ appeared to be significantly higher than that in period $1\left(4.99 \pm 0.30 \mathrm{~m} . \mathrm{s}^{-1}\right)$ and period $3\left(5.03 \pm 0.25 \mathrm{~m} . \mathrm{s}^{-1}\right)$. The maximal heart rate (not measured in period 1) was not significantly different between period 2 and 3 .

\section{Contest performances}

At the end of each training period the subjects had to perform a contest the distance of which was adapted to the respective training. The achievements in the contests for males and females of the TG and FG are shown in Table 3.2.

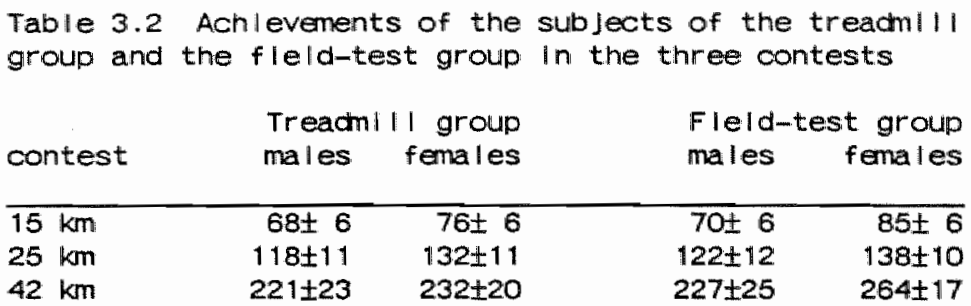

Mean values \pm sd $(\mathrm{min})$

Effect on test performance due to contest

Three days ( $T_{2}$ ) and five days (T3) after the contest the exercise test was repeated to compare test performance and physiological responses with the results of the exercise test $\left(T_{1}\right)$ three days before the contest. The results are presented in Table 3.3.

Treadmill group

Males $(15 \mathrm{~km}$ contest)

No significant differences were found when comparing the parameters determined during the three tests.

Females $(15 \mathrm{~km}$ contest)

The plasma lactate concentration at the first exercise stage (L) was decreased in $T_{2}$ and $T_{3}\left(T_{1}\right.$ vs $T_{2}: p=0.047$ and $T_{1}$ vs $T_{3}$ : $p=0.026)$ and the maximal plasma lactate concentration $\left(L_{m}\right)$ of $T_{2}$ was decreased $(p=0.021)$ with respect test $T_{1}$. The veloclty at 4 mmol.I- $\left[\mathrm{Lac}^{-}\right]\left(V_{1}\right)$ was significantly increased in $\mathrm{T}_{3}$ compared with $T_{1}(p=0.022)$.

Males (25 $\mathrm{km}$ contest)

There was a significant decrease of the heart rate at the first exercise stage $\left(H_{t}\right)$ in $T_{3}$ in comparison with $T_{2}(p=0.011)$ and $a$ significant decrease of the maximal heart rate $\left(H_{m}\right)$ in $T_{2}$ in comparison with $\mathrm{T}_{\mathrm{y}}(\mathrm{p}=0.008)$. The plasma lactate concentration at the first exercise stage ( $\left.L_{r}\right)$ had decreased significantly in $T_{3}$ in comparison with $T_{1}(p=0.031)$ and also at the submaximal exercise stage ( $\left.L_{s}\right)(p=0.033)$. The maximal lactate concentration $\left(H_{m}\right)$ was higher after $T_{3}$ than after $T_{2} \quad(p=0.013)$. The maximal speed $\left(V_{m}\right)$ in exercise test $T_{2}$ was lower than after $T_{1}$ but was similar in $T_{3}\left(T_{2}\right.$ vs $T_{1}: p=0.006 ; T_{2}$ vs $T_{3}: p=0.013$ ). 
Table 3.3 Heart rate. plasma lactate concentratlion and running veloclty before and after the three contests at the exercise tests $T_{1}, T_{2}$ and $T_{3}$

\begin{tabular}{|c|c|c|c|c|c|c|c|c|c|}
\hline \multirow[t]{2}{*}{ Mailes } & \multicolumn{3}{|c|}{$15 \mathrm{~km}$} & \multicolumn{3}{|c|}{$25 \mathrm{~km}$} & \multicolumn{3}{|c|}{$42 \mathrm{~km}$} \\
\hline & $T 1$ & $\mathrm{rz}$ & $T 3$ & $T T$ & $T 2$ & 73 & $\pi 1$ & $T 2$ & 73 \\
\hline \multirow[t]{2}{*}{$H_{f} n$} & 145 & 145 & 1.42 & 150 & 152 & 148 & 15.1 & 152 & 148 \\
\hline & 10 & 10 & 13 & 11 & 12 & 11 & 10 & 9 & 10 \\
\hline \multirow{2}{*}{$\mathrm{H}_{\mathrm{s}} \mathrm{m}$} & 171 & 173 & 172 & 176 & 175 & 175 & 176 & 176 & 177 \\
\hline & 7 & 9 & 9 & $\mathrm{~B}$ & 10 & 10 & 9 & 10 & 9 \\
\hline \multirow[t]{2}{*}{$H_{1}, \mathrm{~m}$} & 156 & 161 & 159 & 164 & 161 & 164 & 169 & 167 & 164 \\
\hline & 16 & 10 & 14 & 10 & 14 & 9 & 8 & 9 & 6 \\
\hline \multirow{2}{*}{$\mathrm{H}_{\mathrm{m}} \mathrm{m}$ s. } & 182 & 181 & 189 & 186 & 183 & 185 & 185 & 182 & 183 \\
\hline & 8 & 7 & 9 & 10 & 9 & 11 & 8 & 8 & 7 \\
\hline \multirow[t]{2}{*}{$L_{f} m$} & 2.63 & 2.38 & 2.44 & 2.74 & 2.77 & 2.52 & 1.89 & 1.99 & 2.05 \\
\hline & 1.01 & 0.69 & 0.85 & 0.88 & 1.01 & 0.70 & 0.39 & 0.82 & 0.77 \\
\hline \multirow{2}{*}{$\mathrm{L}_{\mathrm{si}} \mathrm{m}$. } & 7.51 & 7.50 & 7.84 & 7.33 & 7.90 & 7.25 & 0.35 & 7.20 & 0.92 \\
\hline & 1.74 & 1.80 & 2.17 & 1.93 & 1.84 & 1.97 & 1.98 & 2.04 & 2.45 \\
\hline \multirow{2}{*}{$\ln n$} & 3.49 & 12.64 & 13.33 & 11.98 & 12.29 & 12.46 & 11.16 & 9.85 & 11.19 \\
\hline & 2.68 & 2.82 & 1.98 & 2.19 & 2.17 & 2.18 & 2.11 & 2.34 & 2.30 \\
\hline \multirow{2}{*}{$v_{1} \mathrm{~m}}$. & 3.54 & 3.63 & 3.63 & 3.61 & 3.48 & 3.60 & 3.85 & 3.78 & 3.78 \\
\hline & 0.55 & 0.42 & 0.44 & 0.45 & 0.46 & 0.41 & 0.33 & 0.40 & 0.41 \\
\hline \multirow{2}{*}{$\begin{array}{r}V_{m} \\
\text { sd }\end{array}$} & 4.78 & 4.71 & 4.78 & 4.75 & 4.65 & 4.76 & 4.70 & 4.51 & 4.63 \\
\hline & 0.38 & 0.30 & 0.35 & 0.37 & 0.36 & 0.318 & 0.33 & 0.36 & 0.35 \\
\hline \multirow[t]{2}{*}{ Female } & \multicolumn{3}{|c|}{ - $15 \mathrm{~km}$} & \multicolumn{3}{|c|}{$-25 \mathrm{~km}$} & \multicolumn{3}{|c|}{ * $42 \mathrm{~km}$} \\
\hline & T1 & T2 & $T 3$ & T1 & $\mathrm{T} 2$ & $\mathrm{~T} 3$ & T\| & $\mathrm{T} 2$ & $\mathrm{~T} 3$ \\
\hline \multirow{2}{*}{ 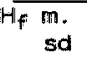 } & 155 & 157 & 155 & 160 & 163 & 159 & 161 & 163 & 155 \\
\hline & 9 & 8 & 11 & 11 & 8 & 11 & 10 & 8 & 12 \\
\hline \multirow{2}{*}{$\begin{array}{r}H_{s} \text { sin. } \\
\text { sd }\end{array}$} & 171 & 174 & 173 & 179 & 181 & 179 & 178 & 184 & 178 \\
\hline & 8 & 9 & 9 & 8 & 9 & 11 & 8 & 9 & 12 \\
\hline \multirow{2}{*}{$H_{1}$ m. } & 159 & 160 & 165 & 173 & 173 & 172 & 175 & 178 & 173 \\
\hline & 18 & 16 & 12 & 12 & 12 & 1.4 & 9 & 11 & 1.4 \\
\hline \multirow{2}{*}{$H_{m} m_{s d}$} & 182 & 18.1 & 182 & 187 & 180 & 187 & 185 & 189 & 185 \\
\hline & 7 & 8 & 15 & 8 & 10 & 9 & 7 & 7 & 12 \\
\hline \multirow{2}{*}{$L_{f}{ }_{s d}$} & 3.40 & 2.63 & 2.43 & 2.42 & 2.55 & 2.17 & 2.14 & 1.79 & 1.88 \\
\hline & 1.49 & 1.01 & 0.55 & 0.8 .1 & 0.93 & 0.80 & 97 & 0.66 & 0.7 .4 \\
\hline \multirow[t]{2}{*}{$\mathrm{L}_{3} \mathrm{~m}}$. & 6.77 & 6.68 & 6.98 & 8.06 & 7.12 & 5.37 & 5.51 & 5.04 & 5.30 \\
\hline & 2.13 & 1.91 & 1.78 & 2,08 & 2.84 & 1.71 & 1.80 & 1.56 & 1.92 \\
\hline \multirow{2}{*}{$\operatorname{Lim}_{s d}^{m .1}$} & 11.119 & 9.35 & 10.40 & 10.35 & 9.45 & 9.05 & 9.55 & 7.75 & 9.22 \\
\hline & 1.87 & 2.19 & 2.68 & 2.94 & 2.34 & 2.35 & 2.57 & 1.76 & 2.73 \\
\hline & 3.18 & 3.24 & 3.36 & 3.48 & 3.33 & 3.47 & 3.47 & 3.53 & 3.47 \\
\hline & 0.34 & 0.32 & 0.17 & 0.15 & 0.35 & 0.32 & 0.41 & 0.27 & 0.26 \\
\hline$v_{m} m$. & 4.17 & 4.091 & 4.13 & 4.20 & 4.03 & 4.19 & 4.17 & 4.103 & 4.11 \\
\hline sd & $0: 24$ & 0.28 & 0,37 & 0.23 & 0.28 & 0.27 & 0.37 & 0.30 & 0.32 \\
\hline
\end{tabular}

He Heart rate $\left(m \| n^{-1}\right)$ at the first exercise stage

$H_{\text {surt }}$ rate $\left(m n^{-1}\right)$ at the sub max. exerclse stage

Hilleart rate $\left(m \| m^{-1}\right)$ at 4 mal. $\|^{-1}$ [Lac-1 (Intrapoliation)

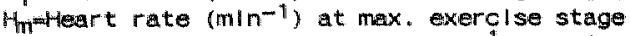

Lfmlasme lactate conc. (mol. $\|^{-1}$ ) at the first exerclse stage Ls - lasma llactate conc. (mmol. $\|^{-1}$ ), at the sub max. exerclse stage $\mathrm{L}^{\mathrm{s}}$ miasm lactate cono. (nmol. $\mathrm{I}^{-1}$ ) at the max. exerclise stage $V_{1}$ manning veloclky (m. $\mathrm{s}^{-1}$ ) at 4 mmol. $\|^{-1}$ [Lac-] (Intrapolation)

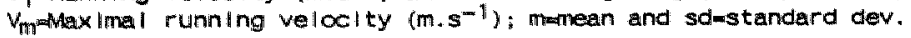


Females $(25 \mathrm{~km}$ contest)

The plasma lactate concentration at the first exercise stage $\left(L_{-}\right)$ had decreased significantly in $T_{3}$ in comparison with $T_{2}(p=0.015)$ and also at the submaximal exercise stage (Lo) $(p=0.008)$. The maximal lactate concentration $\left(\mathrm{Lm}_{\mathrm{m}}\right)$ was lower after $T_{2}$ than after $T_{1}(p=0.047)$. The maximal speed $\left(V_{m}\right)$ in exercise test $T_{2}$ was lower than after $T_{1}$ but it was similar in $T_{3}\left(T_{2}\right.$ vs $T_{1}: p=0.007 ; T_{2}$ vs Ts: $p=0.01$ ).

Males (42 km contest)

There was a significant decrease of the heart rate at the first exercise stage in $T_{3}$ in comparison with $T_{2}(p=0.049)$ and a significant decrease of the maximal heart rate in $T_{2}$ and $T_{3}$ in comparlson with $T_{1}\left(T_{2}\right.$ vs $T_{1}: p=0.004$ and $T_{3}$ vs $\left.T_{1}: p=0.05\right)$. The maximal plasma lactate concentration was lower after $T_{2}$ than after $T_{1}$ $(p=0.028)$.

The maximal speed in exercise tests $T_{2}$ and $T_{3}$ was lower than in $T_{1}$ but greater in $T_{3}$ than in $T_{2}\left(T_{2}\right.$ vs $T_{1}: p=0.001 ; T_{2}$ vs $T_{3}: p=0.013$ and $T_{1}$ vs $T_{3}: p=0.061$ ).

Females $(42 \mathrm{~km}$ contest)

There was a significant decrease of the heart rate at the first exercise stage in $T_{3}$ in comparison with $T_{1}$ and $T_{2}\left(T_{1}\right.$ vs $T_{3}$ : $p=0.018$ and $T_{2}$ vs $T_{3} ; p=0.059$ ). The plasma lactate concentration at the submaximal exercise stage had decreased significantly in $T_{2}$ in comparison with $T_{1}(p=0.015)$. The maximal plasma lactate concentration was lower after $T_{2}$ than after $T_{1}(p=0.011)$ and had increased again in $T_{3}$ in comparison to $T_{2}(p=0.047)$.

\section{Field-test Group}

Table 3.4 gives a survey of the test performances of the field-test group. Three days after the $25 \mathrm{~km}$ contest and the marathon the test performance appeared to be somewhat lower compared to the pre-race test or the five day post-race test.

Table 3.4 Mean running speed at $400 \mathrm{~m}$ and $1000 \mathrm{~m}$ of the fleld-test group before and after the three contests in males and fenales; p-vallues between the exerclse tests of each contest

\begin{tabular}{|c|c|c|c|c|c|}
\hline & & \multicolumn{2}{|c|}{ Males } & Females & \\
\hline & & mean & sd & mean & sd \\
\hline \multirow[t]{3}{*}{$15 \mathrm{~km}$} & $T 1$ & 4.99 & 0.30 & 4.10 & 0.26 \\
\hline & T2 & 4.99 & 0.33 & 4.11 & 0.25 \\
\hline & T3 & 5.10 & 0.32 & 4.12 & 0.26 \\
\hline \multirow[t]{3}{*}{$25 \mathrm{~km}$} & $T 1$ & 5.11 & 0.34 & 4.18 & 0.25 \\
\hline & $T 2$ & 5.07 & 0.35 & $4 \cdot 10$ & 0.26 \\
\hline & T3 & 5.14 & 0.35 & 4.21 & 0.27 \\
\hline \multirow[t]{3}{*}{$42 \mathrm{~km}$} & T1 & 5.03 & 0.25 & 4.13 & 0.29 \\
\hline & $\mathrm{T} 2$ & 4.86 & 0.32 & 4.11 & 0.28 Mean Values \pm sd \\
\hline & $\pi 3$ & 4.95 & 0.29 & 4.09 & In $\mathrm{m} \cdot \mathrm{s}^{-1}$; \\
\hline
\end{tabular}

$15 \mathrm{~km}$ contest 25 contest

$42 \mathrm{~km}$ contest

\begin{tabular}{ccccccccc}
$T_{1} / T_{2}$ & $T_{1} / T_{3}$ & $T_{2} / T_{3}$ & $T_{1} / T_{2}$ & $T_{1} / T_{3}$ & $T_{2} / T_{3}$ & $T_{1} / T_{2}$ & $T_{1} / T_{3}$ & $T_{2} / T_{3}$ \\
\hline$M:$ ns & 0.002 & $<0.001$ & $n s$ & ns & 0.008 & $<0.001$ & $n s$ & $<0.001$ \\
$F:$ ns & 0.012 & 0.036 & 0.031 & ns & 0.009 & $n s$ & $n s$ & 0.043
\end{tabular}


There are two other possibilities to describe the delay of recovery or the lest performance decrease.

Firstly the delay of recovery can be demonstrated using the percentage of the decrease of test performance $\left(\mathrm{m} \cdot \mathrm{s}^{-1}\right)^{3}$ days $\left(\mathrm{T}_{2}\right)$ and 5 days ( $\mathrm{T}_{3}$ ) after each contest in comparison to the test performance 3 days before each contest $\left(T_{1}\right)$ (equations 3.1 and 3.2).

$$
\begin{aligned}
& \mathrm{DT}_{2}=\left(\mathrm{T}_{1}-\mathrm{T}_{2}\right) \cdot \mathrm{T}_{1}-100 \% \\
& \mathrm{DT}_{3}=\left(\mathrm{T}_{1}-\mathrm{T}_{3}\right) \cdot \mathrm{T}_{1}-1.100 \%
\end{aligned}
$$

There was no significant difference for the percentage of test performance $\mathrm{DT}_{2}$ and $\mathrm{DT}_{3}$ between the Treadmill group and the Fleld-test group. Therefore all the data of $T G$ and $F G$ have been put together and then divided into a male and a femalle group (Table 3.5).

In the females it appeared that only the delay of recovery (DT⿰) 3 days after the $25 \mathrm{~km}$ contest had significantly increased in comparison to the $15 \mathrm{~km}$ contest.

When the delay of recovery of the test performance was compared after each contest it appeared that both in males and in females there was an increase of the recovery or a decrease of the delay of recovery of test performance from day 3 to day 5 after each contest ( $M: p<0.001$ and $F: p<0.03$ ). During day 3 and day 5 the recovery resulted even in an increase of the test performances.

Secondly the delay of recovery can be studied by calculating the percentage of the number of subjects who performed less in $T_{2}$ or In $T_{3}$ than in $T_{1}$ (Table 3.6).

The distance of the contests Influenced the delay of recovery 3 and 5 days after the contests (DT's) In males significantly. The p-values between DT 2 's and DT 3 's of the three contests were:

DT $_{2}: 15 \mathrm{~km}$ vs $25 \mathrm{~km} p=0.052 ; 15 \mathrm{~km}$ vs $42 \mathrm{~km} p=0.003 ; 25 \mathrm{~km}$ vs $42 \mathrm{~km}$ $p=0.004$ and $D_{3}: 15 \mathrm{~km}$ vs $25 \mathrm{~km} p=0.048 ; 15 \mathrm{~km}$ vs $42 \mathrm{~km} p=0.008$ $25 \mathrm{~km}$ vs $42 \mathrm{~km} p=0.027$.

Table 3.5 Delay of recovery expressed as test performance decrease $D T_{2}$ after $T_{2}$ and $D T_{3}$ after $T_{3}$ In males and females after the 15,25 and $42 \mathrm{~km}$ contests

\begin{tabular}{lrllrrr}
\hline & $15 \mathrm{~km}$ & $\begin{array}{c}\text { males } \\
25 \mathrm{~km}\end{array}$ & $42 \mathrm{~km}$ & $15 \mathrm{~km}$ & \multicolumn{2}{c}{ females } \\
& & & & & $42 \mathrm{~km}$ \\
\hline $\mathrm{DT}_{2}$ & $0.2 \pm 4.5^{*}$ & $1.2 \pm 3.4^{*}$ & $3.1 \pm 4.1$ & $0.7 \pm 4.0$ & $3.1 \pm 2.8$ & $2.4 \pm 2.3$ \\
DT3 & $-1.5 \pm 4.6^{* 1}$ & $-0.3 \pm 2.8^{*}$ & $0.8 \pm 3.5$ & $-0.8 \pm 4.1$ & $0.0 \pm 3.0$ & $0.4 \pm 4.1$
\end{tabular}

! $p=0.048$ compar Ing $15 \mathrm{~km}$ to $25 \mathrm{~km}$

* p<0.01 compar Ing $15 \mathrm{~km}$ to $42 \mathrm{~km}$

- p<0.03 compar Ing $25 \mathrm{~km}$ to $42 \mathrm{~km}$

vallues in $\%$; see equation (3.1) and (3.2) 
Table 3.6 Distribution $(\%)$ of the number of subjects of the TG and FG that performed less in $T_{2}$ ( 3 days) and $T_{3}$ ( 5 days) after the contest compared wlth $T_{1}$ ( 3 days) before the contest and the results of the MoNemar test

\begin{tabular}{|c|c|c|c|c|c|c|}
\hline contest & $\begin{array}{l}\text { Treadm } \\
\text { males }\end{array}$ & $\begin{array}{l}11 \text { Group } \\
\text { females }\end{array}$ & $\begin{array}{l}\text { Fleld- } \\
\text { males }\end{array}$ & $\begin{array}{l}\text { st Group } \\
\text { females }\end{array}$ & $\begin{array}{l}\text { Moneme } \\
\text { (one-we }\end{array}$ & $\begin{array}{l}r \text { test } \\
\text { y) }\end{array}$ \\
\hline 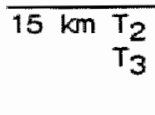 & $\begin{array}{l}82.6 \\
43.6\end{array}$ & $\begin{array}{l}63.6 \\
40.0\end{array}$ & $\begin{array}{l}43.8 \\
28.3\end{array}$ & $\begin{array}{c}46.2 \\
0.0 \\
\text { al }\end{array}$ & $\begin{array}{c}\text { males } \\
\text { females } \\
\text { sub Jects }\end{array}$ & $\begin{array}{l}p=0.227 \\
p=0.145 \\
p=0.076\end{array}$ \\
\hline $25 \mathrm{~km} \mathrm{~T}_{2}$ & $\begin{array}{l}66.7 \\
47.6\end{array}$ & $\begin{array}{l}81.8 \\
45.5\end{array}$ & $\begin{array}{l}60.9 \\
35.6\end{array}$ & $\begin{array}{l}81.8 \\
50.0 \\
\text { all }\end{array}$ & $\begin{array}{l}\text { males } \\
\text { females } \\
\text { sub lects }\end{array}$ & $\begin{array}{l}p=0.005 \\
p=0.035 \\
p<0.001\end{array}$ \\
\hline $\begin{array}{r}42 \mathrm{~km} \mathrm{~T}_{2} \\
\mathrm{~T}_{3}\end{array}$ & $\begin{array}{l}81.0 \\
52.4\end{array}$ & $\begin{array}{r}100.0 \\
55.6\end{array}$ & $\begin{array}{l}81.3 \\
47.1\end{array}$ & $\begin{array}{l}71.4 \\
50.0 \\
\quad \text { all }\end{array}$ & $\begin{array}{l}\text { malles } \\
\text { females } \\
\text { sub jects }\end{array}$ & $\begin{array}{l}P=0.010 \\
P=0.035 \\
P=0.001\end{array}$ \\
\hline
\end{tabular}

Relationship between exercise test and contest

The subjects were coached to perform optimally on the basis of the training and the test performance. The expected running time in the contest was calculated from the subjects" training and testing data. Since weather conditions could not be foreseen, heart rate monitoring gave actual information about the physical stress during the contest to adjust the predicted running velocity.

In Table 3.7 the values of the speed intensity index (SII), heart

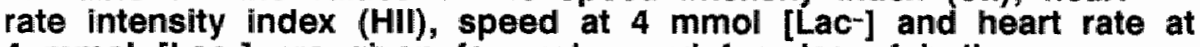
$4 \mathrm{mmol}$ [Lac-] are given for males and temales of both groups. In all groups the running velocity declined with increase of the distance with the exception of the female field-test group that ran faster at $25 \mathrm{~km}(3.01 \pm 0.22 \mathrm{m.s}-1)$ than at $15 \mathrm{~km}\left(2.95 \pm 0.22 \mathrm{~m} . \mathrm{s}^{-1}\right)$. The decline in running velocity was greater from the $25 \mathrm{~km}$ contest to the marathon than that from the $15 \mathrm{~km}$ to the $25 \mathrm{~km}$ contest. In the treadmill group the Sil can be considered as a percentage of $\mathrm{VO}_{2} \max$ pace. For the males this SII amounted to $78 \pm 3 \%, 75 \pm 5 \%$ and $68 \pm 5 \%$ and for the females to $79 \pm 4 \%, 76 \pm 6 \%$ and $74 \pm 5 \%$ in the $15 \mathrm{~km}$, $25 \mathrm{~km}$ and marathon, respectively.

The SLI refers to the anaerobic threshold concept, assuming that the running velocity at a plasma lactate concentration of 4 mmol.1-1 (SLi) is a more valid predictor of endurance performance than the $\mathrm{VO}_{2}$ max speed. For the males this SLI was $105 \pm 10 \%, 98 \pm 11 \%$ and $83 \pm 12 \%$ and for the females $105 \pm 10 \%, 93 \pm 10 \%$ and $89 \pm 8 \%$ in the 15 , 25 and $42 \mathrm{~km}$, respectively.

One has to keep in mind that the decline of the SLI with the Increase of contest distance is not only the result of a slower contest speed, but also of a rise in SLI speed.

As indicator of the physical stress during the contest the heart rate ratio between contest and test figures is used (Table 3.7). In maies the heart rate during the 25 and the $42 \mathrm{~km}$ contest amounted $98 \%$ and $83 \%$ and in females $93 \%$ and $89 \%$ of the maximum heart rate at the exercise iests (TG), respectively. Compared to the heart rate at $4 \mathrm{mmol}$ plasma lactate concentration the mean figures were $104 \%$ and $98 \%$ in males and $102 \%$ and $96 \%$ in females, respectively. 
Table 3.7 Contest performances and Indices of speed intensity (SII), heart rate intensity (HII), speed at 4 mmol [Lac-] and heart rate at 4 mol [Lac-].

\begin{tabular}{|c|c|c|c|}
\hline & $\begin{array}{l}\text { perlod } 1 \\
(15 \mathrm{~km})\end{array}$ & $\begin{array}{l}\text { perlod } 2 \\
(25 \mathrm{~km})\end{array}$ & $\begin{array}{l}\text { per lod } 3 \\
(42 \mathrm{~km})\end{array}$ \\
\hline \multicolumn{4}{|l|}{ TreadmIII group } \\
\hline \multicolumn{4}{|l|}{ males } \\
\hline contest time $(m \| n)$ & $68 \pm 6$ & $118 \pm 11$ & $221 \pm 23$ \\
\hline$v_{c}\left(m \cdot s^{-1}\right)$ & $3.69 \pm 0.32$ & $3.53 \pm 0.34$ & $3.18 \pm 0.33$ \\
\hline sil $(\%)$ & $78 \pm 3$ & $75 \pm 5$ & $68 \pm 5$ \\
\hline HII $(\%)$ & $\mathrm{m}$ & $93 \pm 3$ & $89 \pm 2$ \\
\hline SLI $(\%)$ & $105 \pm 10$ & $98 \pm 11$ & $83 \pm 12$ \\
\hline$H L \mid(\%)$ & $\mathrm{mm}$ & $104 \pm 3$ & $98 \pm 3$ \\
\hline \multicolumn{4}{|l|}{ females } \\
\hline contest time $(\mathrm{m} / \mathrm{n})$ & $76 \pm 6$ & $132 \pm 11$ & $232 \pm 20$ \\
\hline veloclty $\left(\mathrm{m} \cdot \mathrm{s}^{-1}\right)$ & $3.29 \pm 0.25$ & $3.17 \pm 0.26$ & $3.04 \pm 0.26$ \\
\hline SII (\%) & $79 \pm 4$ & $76 \pm 6$ & $74 \pm 5$ \\
\hline $\mathrm{H} \|$ (\%) & $\mathrm{rm}$ & $93 \pm 3$ & $90 \pm 7$ \\
\hline SLI $(\%)$ & $105 \pm 10$ & $93 \pm 10$ & $89 \pm 8$ \\
\hline HLI (\%) & $\mathrm{mm}$ & $102 \pm 7$ & $96 \pm 5$ \\
\hline
\end{tabular}

Fleld-test group

males

$\begin{array}{ll}\text { contest time }(\mathrm{m} / \mathrm{n}) & 70 \pm 6 \\ \text { velocity }\left(\mathrm{m} . \mathrm{s}^{-1}\right) & 3.55 \pm 0.32\end{array}$

sil (\%)

HII (\%)

$71 \pm 4$

$122 \pm 12$

$227 \pm 25$

$3.42 \pm 0.33$

$68 \pm 4$

3. $10 \pm 25$

$62 \pm 6$

$92 \pm 4$

$89 \pm 4$

females

$\begin{array}{lc}\text { Contest } t \text { lme }(\mathrm{m} / \mathrm{n}) & 85 \pm 6 \\ \text { veloolty }\left(\mathrm{m} . \mathrm{s}^{-1}\right) & 2.95 \pm 0.22 \\ \text { sil }(\%) & 72 \pm 3\end{array}$

m

$138 \pm 10$

$264 \pm 17$

$3.01 \pm 0.22$

$73 \pm 4$

$2.66 \pm 0.17$

$65 \pm 6$

$\mathrm{m}$

$86 \pm 9$

Mean valuestsd

$\mathrm{m}$ m not measured

Sil see equation 2.2 (p. 36)

HII see equat Ion 2.3 (p. 36)

$V_{c}$ mean contest velocity dur Ing the contests (m.s $\mathrm{s}^{-1}$; meantsd)

SLI mquotlent of velocity at 4 mmol. $1^{-1}$ [Lac-] in $T_{1}$ before each contest and the mean velocity of the contest multiplled by $100 \%$

$H L \mid=q u o t$ lent of heart rate at 4 mol. $1^{-1}$ [Lac-] in $T_{1}$ before each contest and the mean heart rate during the contest multiplled by $100 \%$

SLI=quot lent of velocity at 4 moll. $1^{-1}$ [Lac-] In $T_{1}$ before each contest and the mean veloclty of the contest multiplled by $100 \%$ 


\section{Prediction of performance in long distance runs}

By comparing the results of the exercise tests (both treadmill and field tests) with the performance of the participants in the 15, 25 and $42 \mathrm{~km}$ contests a high negative correlation was observed between the maximal speed in the treadmill group (TG) and the running time in the contests, which decreased with the increase of the distance of the contests both in males and in females (Table 3.8). The achievements of the subjects of the treadmill group (TG) and the field group (TG) did not differ in any of the contests.

Table 3.8 Correlation between the running speed of Test 1 and the Speed Intensity Index (SII), and the running time in the three contests of males and females

\begin{tabular}{|c|c|c|c|c|c|c|c|c|}
\hline \multirow{2}{*}{\multicolumn{3}{|c|}{ malles }} & \multicolumn{2}{|c|}{$15 \mathrm{~km}$} & \multicolumn{2}{|c|}{$25 \mathrm{~km}$} & \multicolumn{2}{|c|}{$42 \mathrm{~km}$} \\
\hline & & & TG & $\mathbf{F G}$ & TG & $F G$ & TG & $\mathrm{FG}$ \\
\hline & $\begin{array}{l}v_{T 1}: t \text { Ime } \\
\text { sI I:t Ime }\end{array}$ & $\begin{array}{l}r \\
p \\
r \\
p\end{array}$ & $\begin{array}{l}-0.91 \\
<0.001 \\
-0.22 \\
0.30\end{array}$ & $\begin{array}{l}-0.78 \\
<0.001 \\
-0.71 \\
<0.001\end{array}$ & $\begin{array}{l}-0.66 \\
<0.001 \\
-0.67 \\
<0.001\end{array}$ & $\begin{array}{l}-0.77 \\
<0.001 \\
-0.70 \\
<0.001\end{array}$ & $\begin{array}{c}-0.54 \\
0.006 \\
-0.71 \\
<0.001\end{array}$ & $\begin{array}{c}-0.46 \\
0.002 \\
-0.86 \\
<0.001\end{array}$ \\
\hline & females & & $\mathrm{TG}^{15}$ & $\mathrm{~km}_{\mathrm{FG}}$ & $\mathrm{TG}^{25}$ & $\begin{array}{c}\mathrm{km} \\
\mathrm{FG}\end{array}$ & $\mathrm{TG}^{42}$ & $\begin{array}{l}\mathrm{km} \\
\mathrm{FG}\end{array}$ \\
\hline & $\begin{array}{l}v_{T 1}: t \text { Ime } \\
\text { sil:time }\end{array}$ & $\begin{array}{l}r \\
p \\
r \\
p\end{array}$ & $\begin{array}{c}-0.73 \\
0.005 \\
-0.55 \\
0.083\end{array}$ & $\begin{array}{c}-0.73 \\
0.004 \\
-0.60 \\
0.039\end{array}$ & $\begin{array}{c}-0.71 \\
0.007 \\
-0.65 \\
0.032\end{array}$ & $\begin{array}{c}-0.68 \\
0.010 \\
-0.56 \\
0.077\end{array}$ & $\begin{array}{c}-0.50 \\
0.088 \\
-0.45 \\
0.22\end{array}$ & $\begin{array}{r}0.07 \\
0.40 \\
-0.50 \\
0.39\end{array}$ \\
\hline $\begin{array}{l}r \\
p \\
T G \\
F G \\
v_{T} 1 \\
t \mid m e \\
S I I\end{array}$ & $\begin{array}{l}\text { moorre } \\
\text { mp-vall } \\
\text { =treadr } \\
\text {-fleld } \\
\text { mrunn Ir } \\
\text { m munn Ir } \\
\text { see ed }\end{array}$ & $\begin{array}{l}\text { lat } \\
\text { ue } \\
\text { nil } \\
\text { te } \\
\text { ng } \\
\text { ng } \\
\text { qua }\end{array}$ & $\begin{array}{l}\text { on coef } \\
\text { group } \\
\text { group } \\
\text { peed in } \\
\text { Ime of } \\
\text { lon } 2.2\end{array}$ & $\begin{array}{l}\text { Test } 1 \\
\text { contest } \\
.2 \text { (p. }\end{array}$ & $\begin{array}{l}\left(m \cdot s^{-1}\right) \\
(m \mid n) \\
36)\end{array}$ & an) & & \\
\hline
\end{tabular}

\section{Discussion}

In sport activities Ilike endurance running, exercise testing is used to evaluate the training status. Fair correlations between maximal oxygen uptake, anaerobic threshold and running economy on the one hand and level of performance in competition on the other have been shown $(1,2,6,7,11,12,13,15)$. However, the best predictor of performance in sport remains performance in regular competition.

The main reason for such a conclusion is the restricted validity of any exercise test.

In the present study exercise testing was used to study adaptations to a progressive endurance training programme in recreational runners. Moreover, exercise testing after contests was used to search for incomplete recovery in terms of test performance or physiological responses. 
Training effects

Figures of a running test prior to the start of the training are not avallable, but as part of a medical examination the subjects performed a progressive bicycle ergometer test until exhaustion both before and after the whole training period. The mean and sd of the increase in maximal workload was in males $11.3 \pm 8.8 \%$ and in females $11.0 \pm 12.0 \%$ (see Table $2.3 ;$ p. 27). The figures of the treadmill- and field-tests did not show any improvement in test performance (Table 3.2) from the first $(15 \mathrm{~km}$ contest) to the third (marathon) training period. The training effect in the first period on test performance (exercise intensity near $\mathrm{VO}_{2} \max$ llevel) was apparently already maximal since it was not the intensity but the volume of training that was raised further. Hickson et al. (8) found that the training-induced rise in maximal oxygen uptake was already achleved within 3 weeks in spite of an increased training stimulus. Another reason for the fact that there was no increase of the maximal test velocity was the time schedule and the way of training. Firstly it was necessary to increase the endurance capacity to run a marathon and not (after adaptation to endurance activity to run competition contests) running at a very high intensity level (17). A remarkable finding was the rise of the heart rate in males and females at similar exercise intensities in the second and third training period compared to the first one (see Table 3.1). In training studies a tendency to decline is usually found. It does not seem likely that the small rise of heart rate $\left(3-5\right.$ b.min $\left.{ }^{-1}\right)$ has had a significant effect on cardiac output since in that case maximal oxygen uptake and thus the test performance should have been increased. The effect of training on body weight is reported in Chapter 2.

\section{Contest effects}

At the end of each training period a contest was scheduled to study the effects of physical stress compared to that of the daily training programme. It was hypothesized that the duration of physical recovery would depend on the duration of the exercise due to the distance of the contest. Treadmill- and fleld-tests on the third and fifth day after the contest were used to judge the level of physical performance and physiological responses to exercise as possible parameters of physical recovery. On the third day $\left(T_{z}\right)$ after the $15 \mathrm{~km}$ contest the exercise test performance showed no significant decrease in comparison to the test performance before the contest $\left(T_{1}\right)$. The test performance in $T_{2}$ after $25 \mathrm{~km}$ and $42 \mathrm{~km}$ contests were significantly lower than in $T_{1}$. On the fifth day after the $25 \mathrm{~km}$ contest the test performance was again achieved. However, the test performance in $T_{3}$ after the $42 \mathrm{~km}$ contest tended to be lower than in $T_{+}(p=0.061)$. This implies that the greater the contest distance the longer the recovery time in relation to the test performance (Table 3.4). However, the results approached from the viewpoint of the decrease of the percentage of test pertormance on the one hand and the percentage of the subjects who have performed less in $T_{2}$ and/or $T_{3}$ after the contests in relation with 
$T$, before the contests on the other hand demonstrate recovery differences. From these data it can be concluded that the recovery after the 25 and $42 \mathrm{~km}$ contests certainly takes more time than 3 days, as the number of subjects with a test performance in $T_{2}$ lower than in $T_{3}$ was significantly higher. These results suggest that the females need similar time to recover both after the 25 and after the $42 \mathrm{~km}$ contests, because there was no difference in the test performance decrease after the 25 and $42 \mathrm{~km}$ contests. Besides significant decreases were shown both at maximal and submaximal level in the plasma lactate concentration and heart rate after $T_{2}$ in relation with $T_{1}$ especially after the marathon (Table 3.4). Simllar results have been shown in a study with horses (3). When considering these findings one might conclude that physical recovery after a long distance run is rather prompt as measured in progressive exercise of limited duration (about $20 \mathrm{~min}$ ) or in track runs of 400 and $1000 \mathrm{~m}$. However, no conclusion can be drawn with respect to endurance performance since the test performances and physiological variables were significantly influenced by the distance of the contests.

\section{Contest performance}

Each subject received instructions concerning his/her running strategy based on training experiences and test results.

Furthermore in most of the contests the heart rate was monitored to inform the subjects about their actual physical loading.

In the $15 \mathrm{~km}$ contest the running speed exceeded that of $V_{1}$ with $5 \%$. In the $25 \mathrm{~km}$ contest and the marathon the absolute running velocity declined progressively despite an increase of $V_{1}$. The difference between the treadmill- and field-test group concerning their speed intensity index (SII) is mainly caused by the running speed in the field-test (sum of $400 \mathrm{~m}$ and $1000 \mathrm{~m}$ runs) which is higher than the maximum speed in the progressive treadmlli-test. When considering the heart rate intensity index (HII) between the contests and the respective exercise tests as parameter of physical stress, the heart rate of $V_{1}$ appeared to be in fair correspondence with that of the contests. In the $25 \mathrm{~km}$ contest the heart rate was $3 \%$ higher and in the marathon $3 \%$ lower than that of $V_{1}$. All these findings regarding the relationships between exerclse tests and contest performance are in agreement with those of elite runners in literature $(1,5,10,15)$.

In general it can be concluded that endurance training effects in people with moderate disposition are similar to those in athletes. incomplete recovery after endurance racing can be demonstrated in exercise testing, but the differences are very small and they are not reflected in responses of heart rate and plasma lactate concentration after the $15 \mathrm{~km}$, but may be reflected after the marathon and to a lesser extent after the $25 \mathrm{~km}$ contest. As there is in malles a good and in females a moderate correlation between SII and running time in contests (Table 3.8 ), and the achievements of the treadmill group and the field test group did not differ in any contest, the results of the field test may be used as indicators for the performance in contests. 


\section{Peferences}

1 Conconi F., Ferrari M., Ziglio P.G., Droghettl P., Codeca L.: Determination of the anaerobic threshold by a noninvasive fleld test in runners. J. Appl. Physiol.: Resp Envir Exerc Physiol 52(4):869-873,1982.

2 Conley D.L., Krahenbuhl C.S.: Running economy and distance running performance of highly trained athletes. Med Sci Sports Exerc, 12(5):357-360,1980.

3 Costill D.L., Maglisho E.W., Fitts R., Morgan W., Wilmore J., and Kulpers H.: Overtraining: physicall and psychological effects of a sudden Increase in training. Med Sci Sports Exerc (abstract) 19(2):577,1987.

4 Davis J.A., Frank M.H., Whipp B.J., Wasserman K.: Anaerobic threshold alterations caused by endurance training in middle aged man. J Appl Physiol 46:1039-1046,1979.

5 Fohrenbach R., Mader A.y Hollmann W.: Determination of endurance ccapacity and prediction of exercise intensities for training and competition in marathon runners. Int $J$ Sports Med 8:11-18,1987.

6 Foster $\mathrm{C} .: \mathrm{VO}_{2} \mathrm{max}$ and training indlces as determinants of competitive running performance. J Sports Sci 1:13-22,1983.

7 Heck H., Mader A., Hess G., Mücke S., Müller R., Hollmann W.: Justification of the $4-\mathrm{mmol} / /$ lactate threshold. Int $J$ Spgrts Med 6:117-130,1985.

8 Hickson R.C., Hagberg J.M., Ehsanl A.A., Holloszy J.O.: Tlme course of the adaptive responses of aerobic power and heart rate to training. Med Scl Sports Exerc 13(1):17-20,1981.

9 Holloszy J.O.: Blochemlcal adaptations to exerclse: aerobic metabolism. Exerc Sports Sci Rev 1:45-71,1973.

10 LaFontaine T.P., Londeree B.R. Spath W.K.: The maximal steady state versus selected running events. Med Scl Sports Exerc, 13(1):190-192,1981.

11 Lehmann M., Berg A., Kapp R., Wessinghage T., Keul J.: Correlations between laboratory testing and distance running performance in marathoners of similar performance abillty. Int $J$ Sports Med 4:226-230,1983.

12 Maughan R.J., Leiper J.B.: Aeroblc capacity and fractional utllisation of aerobic capacity in ellte and non-ellte male and female marathon runners. Eur J Appl Physlol 52:80-87, 1983.

13 Prampero P.E. di, Atchou G, Brückner J.C., Mola C.: The energetics of endurance running. Eur J Appl Physlol 55: 259-266,1986.

14 Ramsbottom R., Nute M.G.L., Williams C.: Determinants of five kllometre running performance in active men and women. Brit J Sports Med 21(2):9-13,1987.

15 Scrimgeour A.G., Noakes T.D., Adams B., Myburgh K.: The influence of weekly training distance on fractional utilization of maximum aeroblc capacity in marathon and ultramarathon runners. Eur $J$ Appl Physiol 55:202-209,1986. 
16 Sjödin B., Jacobs I., Svedenhag J.: Changes in onset of blood lactate accumulation (OBLA) and muscle enzyme after training at OBLA. Eur J Appl Physiol 49:45-57,1982.

17 Tanaka K., Watanabe H., Konishi Y., Mitsuzono R., Sumida S., Tanaka S., Fukuda T., Nakadomo $F$. .: Longitudinal associations between anaerobic threshold and distance running performance. Eur J Appl Physiol 55:248-252,1986. 
Chapter 4 Catabolic and anabolic changes associated with endurance exercise

4.1 Plasma urea, creatinin, uric acid, albumin and total protein concentrations before and after 15, 25 and $42 \mathrm{~km}$ contests

\section{Introduction}

Physical exercise may result in a transient change in homeostasis. Increases in plasma urea and uric acid concentration may indicate increased catabolism $(6,7,8,13,15,21,24)$; the concentration of creatinin, a degradation product of creatine from muscle tissue, may also be increased in a catabolic state $(19,21)$. It has not been well documented whether changes in the concentration of albumin and total protein can be used as parameters for an increased catabolic state after prolonged physical exercise $(3,4,15,18,20,23,25,28)$. The aim of this part of the study was to determine changes of plasma urea, creatinin, uric acid, albumin and total protein concentration after exercise tests and contests of 15, 25 and $42 \mathrm{~km}$ in order to consider whether these changes, if present, might be a measure for the degree of exercise stress and/or for the speed of the recovery phase. In addition gender differences regarding these variables were studied (7).

The design of the present investigation (Fig. 2.1) also allowed to study the changes of albumin, total protein and metabolite (urea, creatinin and uric acid) concentrations as a response to training by comparing the plasma concentrations of these variables in the course of the study with the basic levels in samples taken betore each contest.

Factors which have to be considered in assessing these changes are the reduced blood flow through the splanchnic area and the functioning of kidneys and liver after physical stress. As kidneys and IIver play an Important role In metabolism and clearance of creatinin, urea and uric acid, plasma concentration of these substances may give information about the functional state of these organs after physical exercise. To get an impression of liver functions, the changes concerning L-Alanine aminotransferase (Alat) were determined $(16,21)$.

\section{Materials and methods}

A detalled protocol of the study has been reported in Chapter 2 and is schematically shown in Fig. 2.2. Plasma concentrations of urea, creatinin and uric acid, albumin and total protein were measured in blood sample numbers 1 to 15 . In Fig. 4.1.1 the protocol of blood sampling is depicted. Methods for the determination of these variables have been described in Chapter 2 on p. 32-33. 
FIELDTEST GAOUP

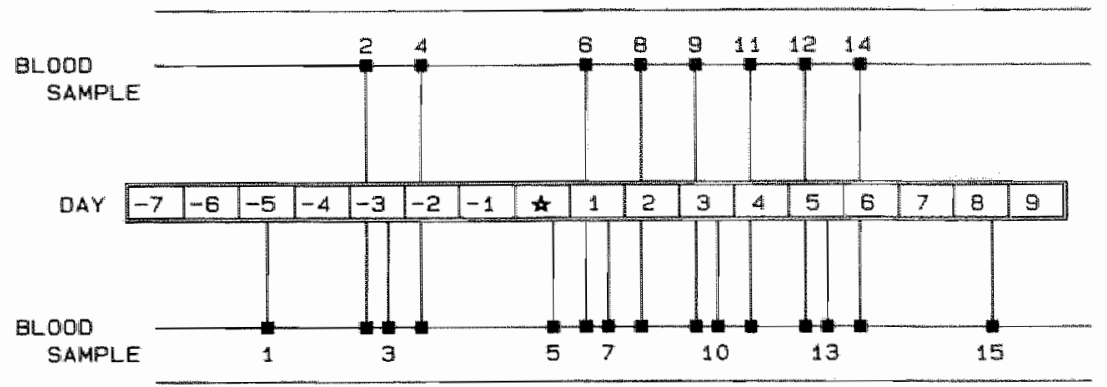

TAEADMILLE GROUP

Fig. 4.1.1 Time schedule of the protocol before and after the three contests with speclal reference to the time intervals for blood sampling.

\section{Results}

Plasma urea, creatinin and uric acid

Mean plasma concentrations of urea, creatinin and uric acid before and after the contests of all subjects are shown in Table 4.1.1. As basic levels are used the mean plasma concentrations of the samples 2 and 4. The basic level was used as reference value in Figs. 4.1.2 to 4.1.4. A significant increase in plasma urea concentration after the $15 \mathrm{~km}$ contest lasted in males until $26 \mathrm{~h}$ (sample 7) and in females until $16 \mathrm{~h}$ post-contest (sample 6). After the $25 \mathrm{~km}$ contest the increase in males also lasted until $26 \mathrm{~h}$ post-contest, but in females the increase in plasma urea concentration lasted until $40 \mathrm{~h}$ post-contest (sample 8). After the marathon the increase in plasma urea concentration lasted until $40 \mathrm{~h}$ post-contest both in males and females.

In males as well as in females the increase in urea plasma concentration was roughly proportional to the distance of the contest. The concentration of urea 4-6 h (sample 5) after the marathon (42 $\mathrm{km}$ race) was significantly higher compared to that obtained in the other contests $(15 \mathrm{~km} / 42 \mathrm{~km}$ and $25 \mathrm{~km} / 42 \mathrm{~km}$ in males, $p<0.01$ and $p<0.0001$, respectively). In females no significant differences were observed in plasma urea concentration between the different contests. The urea concentration normalized within 2-3 days after the contests.

The mean increase of creatinin plasma concentration due to the contests and the decrease afterwards were similar in males and females. The maximal values 4-6 $\mathrm{h}$ after each contest and the decrease between 4-6 $h$ and 16-18 $h$ (sample 6) after a contest were hardly influenced by the contest length or by the duration of exercise (Table 4.1.1).

16-18 $\mathrm{h}$ after the contests the creatinin concentration in males and females was significantly higher than the basic levels.

(M:15 km; $p<0.001,25 \mathrm{~km} ; \mathrm{p}=0.001$, and $42 \mathrm{~km} ; \mathrm{p}<0.001$ )

( $F: 15 \mathrm{~km} ; p=0.021,25 \mathrm{~km} ; p>0.10$, and $42 \mathrm{~km} ; p=0.024)$. 
Table 4.1.1 Plasma urea, creatinin and uric acld concentrations before and after the 15,25 and $42 \mathrm{~km}$ contest

\begin{tabular}{|c|c|c|c|c|c|c|c|c|c|c|c|c|}
\hline & \multicolumn{4}{|c|}{ Males } & \multicolumn{8}{|c|}{ Females } \\
\hline & $\begin{array}{l}\text { Urea } \\
\text { mean }\end{array}$ & sol & $\begin{array}{c}\text { Creat } \\
\text { mean }\end{array}$ & $\begin{array}{l}=\ln \ln \\
\text { sd }\end{array}$ & $\begin{array}{l}\text { Ur lo } \\
\text { mean }\end{array}$ & $\begin{array}{c}\text { acid } \\
\text { sod }\end{array}$ & $\begin{array}{l}\text { Urea } \\
\text { mean }\end{array}$ & sd & $\begin{array}{l}\text { Crea } \\
\text { mean }\end{array}$ & inin & $\begin{array}{l}\text { Ur lic } \\
\text { mean }\end{array}$ & $\begin{array}{c}\text { acid } \\
\text { sd }\end{array}$ \\
\hline $1 \mathrm{~A}$ & 5.2 & 1.3 & 87 & 7 & 0.30 & 0.05 & 4.7 & 1.0 & 77 & 8 & 0.23 & 0.06 \\
\hline B & 5.3 & 1.3 & 83 & 7 & 0.29 & 0.06 & 4.8 & 1.2 & 75 & 8 & 0.21 & 0.05 \\
\hline c & 5.8 & 1.1 & 82 & 6 & 0.28 & 0.07 & 5.4 & 1.1 & 75 & 10 & 0.24 & 0.08 \\
\hline $2 A$ & 5.2 & 1.0 & 85 & 10 & 0.28 & 0.05 & $\$ .7$ & 1.0 & 75 & 7 & 0.22 & 0.06 \\
\hline B & 5.0 & 1.2 & 84 & 7 & 0.30 & 26 & 5 & 1.1 & 74 & 4 & 23 & .05 \\
\hline C & 5.2 & 1.0 & 81 & 8 & 0.28 & 0.07 & .6 & 1.0 & 72 & 7 & 0.21 & 0.04 \\
\hline $3 A$ & 5.8 & 1.2 & 88 & 7 & 0.32 & 0.06 & .2 & 0.7 & 77 & 7 & .24 & 0.07 \\
\hline B & 5.9 & 1.2 & 87 & 9 & 0.32 & 0.06 & .2 & 1.2 & 76 & 7 & .25 & 0.05 \\
\hline c & 5.9 & 1.4 & 84 & 8 & 0.30 & 0.06 & 5.3 & 0.6 & 73 & 10 & .23 & 0.05 \\
\hline $4 A$ & 5.3 & 1.4 & 85 & 7 & 0.32 & 0.05 & 4.5 & 0.8 & 76 & 6 & 0.23 & 0.06 \\
\hline B & 5.4 & 1.1 & 86 & 8 & 0.35 & 0.06 & 4.8 & 0.9 & 74 & 7 & 0.24 & 0.05 \\
\hline C & 5.5 & 1.2 & 85 & $B$ & 0.29 & 0.07 & 4.7 & 1.2 & 74 & 6 & 0.23 & 0.04 \\
\hline $5 A$ & 6.3 & 1.4 & 108 & 13 & 0.36 & 0.05 & 5.9 & 1.3 & 98 & 15 & 0.27 & 0.05 \\
\hline B & 6.5 & 1.4 & 105 & 18 & 0.36 & 0.07 & 6.3 & 1.1 & 96 & 20 & 28 & 0.06 \\
\hline C & 7.3 & 1.7 & 108 & 27 & 0.35 & 0.06 & .4 & 1.2 & 93 & 20 & 27 & 0.05 \\
\hline $6 \mathrm{~A}$ & 5.9 & 1.3 & 93 & 19 & & & 1 & 1.0 & 81 & 11 & & 0.06 \\
\hline B & 6.0 & 1.6 & 92 & 10 & 0 & 0 & 2 & 0.7 & 17 & 8 & & .05 \\
\hline C & 7.3 & 1.7 & 93 & 15 & 4 & & 3 & 1 & 8 & 6 & & 0.05 \\
\hline $7 A$ & 6.1 & 1.4 & 90 & 11 & 0.31 & 0 & 0 & 1 & 78 & 10 & 22 & 0.06 \\
\hline B & 6.4 & 1.6 & 93 & 11 & 0.32 & 0 & .5 & 1. & 78 & 11 & 23 & 0.05 \\
\hline c & 7.4 & 1.7 & 91 & 14 & 0.32 & 0. & .7 & 1. & 80 & 11 & .23 & 0.05 \\
\hline $8 A$ & 5.5 & 1.4 & 87 & 8 & 0.29 & 0. & 6.2 & 1. & 77 & 9 & 22 & 0.09 \\
\hline B & 5.4 & 1.3 & 88 & 7 & 0.32 & 0.0 & 5.1 & 0.8 & 77 & 10 & 0.24 & 0.05 \\
\hline C & 6.4 & 1.1 & 88 & 9 & 0.32 & 0 & .4 & o. & 77 & 7 & .24 & 0.06 \\
\hline $9 \mathrm{~A}$ & 5.3 & 1.2 & 87 & 8 & 0.29 & 0 & .0 & 1. & 78 & 5 & 21 & 0.04 \\
\hline B & 4.9 & 1.1 & 85 & 7 & 0.30 & 0.06 & 4.7 & 0. & 76 & 7 & 1.24 & 0.04 \\
\hline C & 5.2 & 1. & 8 & 8 & $\theta$ & 0 & .7 & 0 & 71 & 6 & 2 & 05 \\
\hline $10 \mathrm{~A}$ & & & 8 & 9 & & & & & 78 & 6 & & 04 \\
\hline B & 5.6 & 1.0 & 87 & 9 & 31 & 0 & 3 & 1.0 & 75 & $B$ & 25 & 0.04 \\
\hline c & 5.7 & 1.5 & 8 & 7 & 0 & 0 & 4 & 0.7 & 72 & 6 & 22 & .06 \\
\hline $11 \mathrm{~A}$ & 5.8 & 1 & 8 & 7 & 10 & 0 & 8 & 1 & 77 & 7 & 21 & .05 \\
\hline B & 5.3 & 1.2 & 8 & 7 & 0 & 0 & .0 & 1. & 75 & 6 & 24 & 05 \\
\hline c & 5.4 & 1. & 81 & 11 & 0 & 0 & 4.6 & 0 . & 73 & 8 & 22 & 0.05 \\
\hline $12 \mathrm{~A}$ & 5.2 & 1. & 87 & 11 & 0.29 & 0 & 4.8 & 1. & 78 & 7 & 0.21 & 0.05 \\
\hline B & 4.8 & 0. & 8 & 7 & 0.31 & 0. & 4.8 & 1. & 74 & 6 & 0.23 & 0.05 \\
\hline c & 4.8 & 1.2 & 81 & 7 & 0.30 & 0 & 4.3 & 0.8 & 70 & 8 & 0.20 & 0.05 \\
\hline $13 \mathrm{~A}$ & 5.9 & 1.4 & 90 & 9 & 0.30 & 0.0 & 5.1 & 1. & 79 & 7 & 0.23 & 0.04 \\
\hline B & 5.6 & 1.0 & 87 & 9 & 0.34 & 0 & 5.2 & 1 & 76 & 10 & .24 & 0.04 \\
\hline C & 5.7 & 1. & 85 & 7 & 1 & 0.0 & 4.6 & 1 & 75 & 12 & 23 & .05 \\
\hline $14 \mathrm{~A}$ & 5.7 & 1.5 & 88 & 7 & 0.31 & 0 & 4.6 & o. & 77 & 7 & .22 & 0.05 \\
\hline B & 5.4 & 1.2 & 8.4 & 7 & 33 & 0 & 4.8 & 1 & 75 & 6 & 23 & 0.05 \\
\hline c & 5.5 & 1.3 & 83 & 7 & 31 & 0. & 4.4 & 1 & 73 & 9 & 0.21 & 0.05 \\
\hline $15 \mathrm{~A}$ & 5.2 & 1.3 & 90 & 9 & 0.30 & 0.0 & 4.8 & 0.9 & 77 & 7 & 0.21 & 0.06 \\
\hline B & 5.3 & 1.2 & 86 & 6 & 0.33 & 0.06 & 4.8 & 0.8 & 75 & 8 & 0.23 & 0.05 \\
\hline C & 4.8 & 0.7 & 81 & 8 & 0.31 & 0.07 & 5.0 & 1.9 & 77 & 3 & 0.25 & 0.05 \\
\hline
\end{tabular}

Mean values \pm sd of urea $\left(\right.$ mol. $\left.\left.\right|^{-1}\right)$, creatinin $\left(\mid \mathrm{mol}, \mathrm{I}^{-1}\right)$ and ur Ic acld (mol. $1^{-1}$ ) are given of the samples before and after the 15 (A), the 25 (B) and the $42 \mathrm{~km}$ contest (C). 

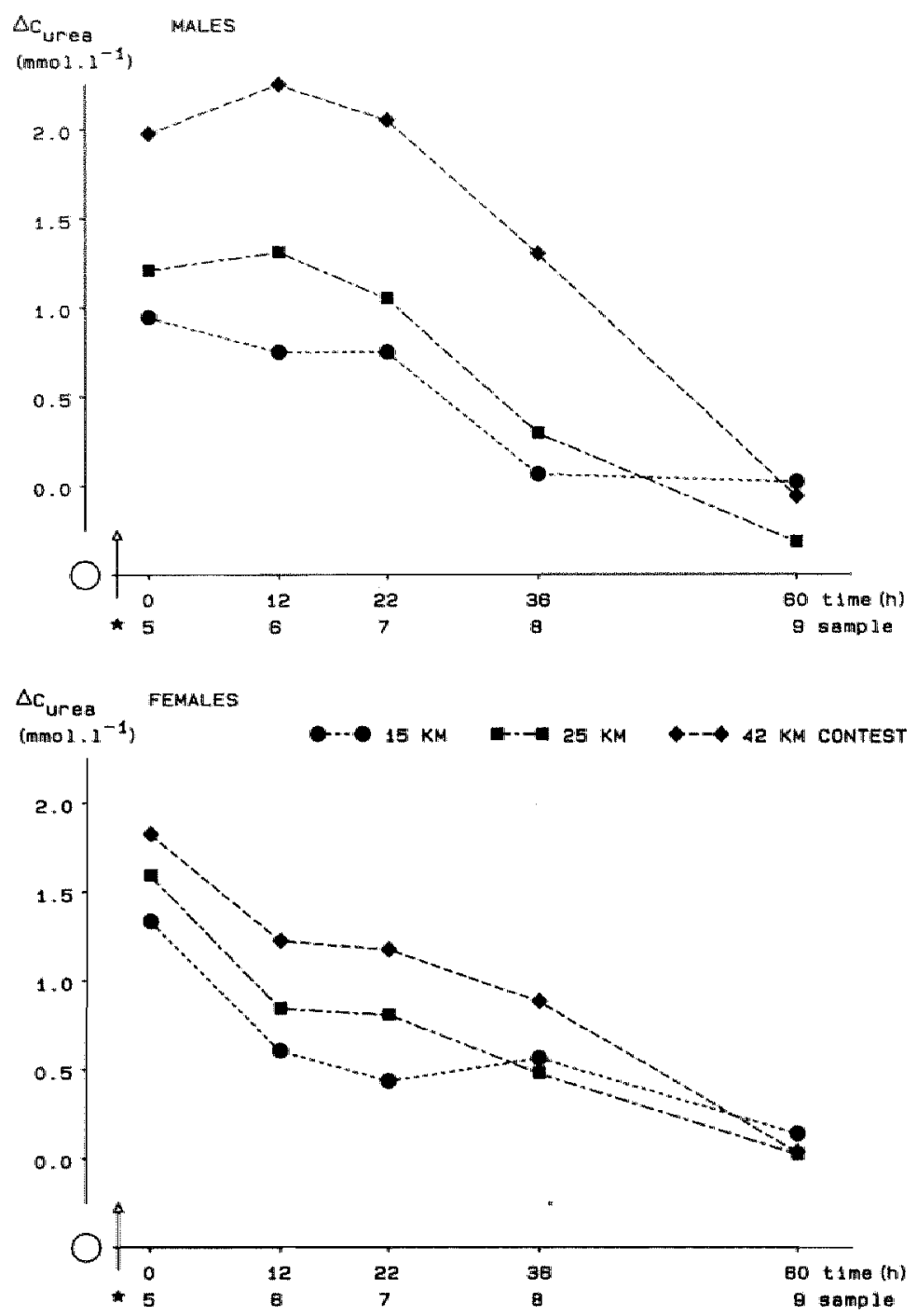

Flig. 4.1.2 Time course of delta urea concentration in plasma after the contests; see Table 4.1.1. The values at $t=0$ were determined in plasma obtalned 4-6 $\mathrm{h}$ (sample 5) after the contest.

The creatinin concentration increased after physical exercise and decreased fairly quickly in the course of time (Fig. 4.1.3). However, it remained significantly higher in males until two days (sample 8 ) after the 25 and $42 \mathrm{~km}$ compared to basic level $(25 \mathrm{~km}: \mathrm{p}=0.003$; 42km:p<0.001). 

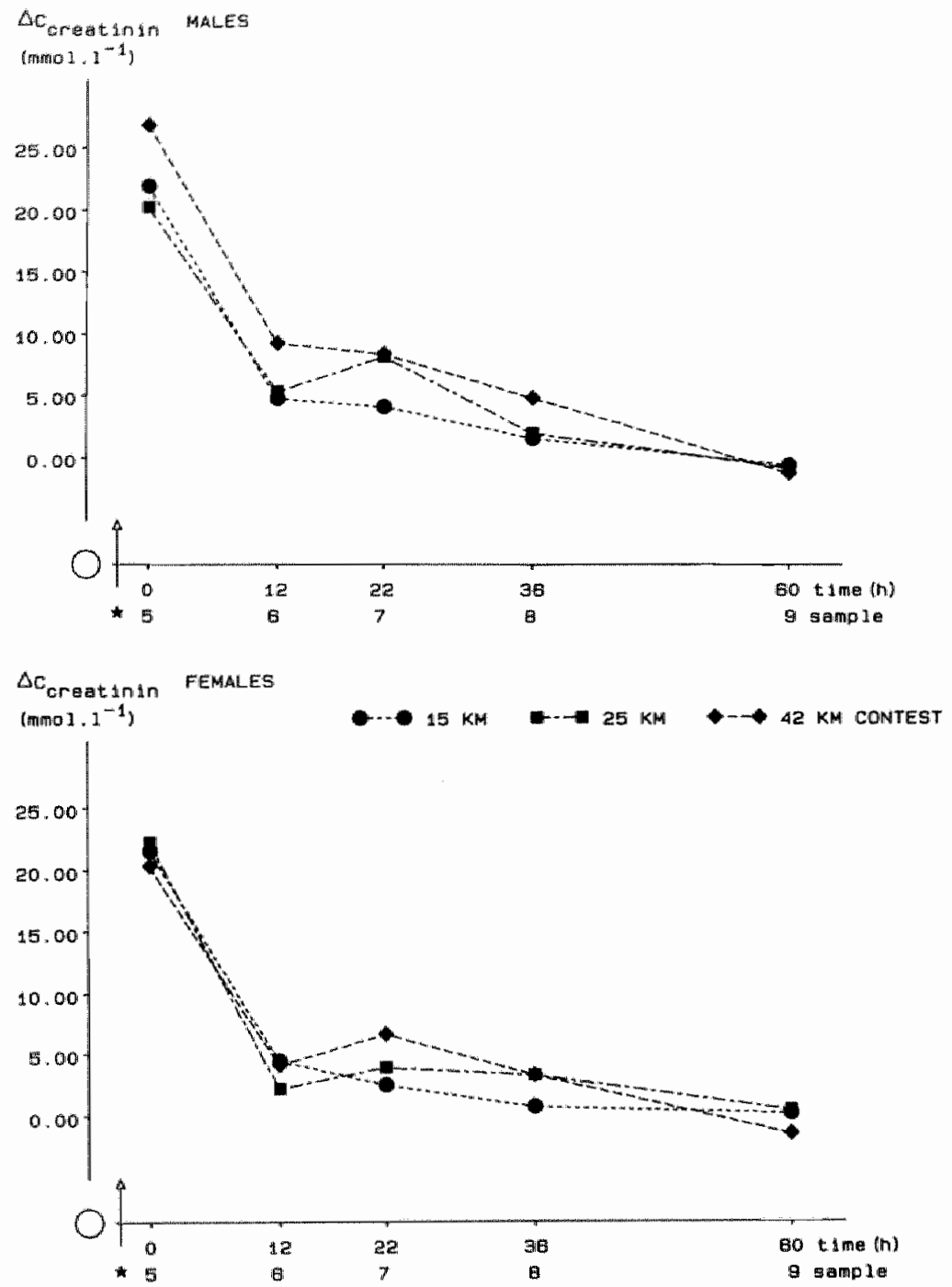

Flg. 4.1.3 Time course of delta creatinin concentration in plasma after the contests" see Table 4.1.1. The values at $t m 0$ were determined in plasma obtalned 4-6 h (sample 5) after the contest.

The maximal values of the uric acid concentration 4-6 $\mathrm{h}$ after each contest and the decrease between 4-6 $h$ and 16-18 $h$ after a contest were hardly influenced by the distance of the contest or by the duration of the exercise (Table 4.1.1). 
Uric acid concentrations decreased during the first day after a contest to basic levels except after the marathon (Fig. 4.1.4). On the second day and third day after the contest uric acid concentrations decreased even below the basic level.
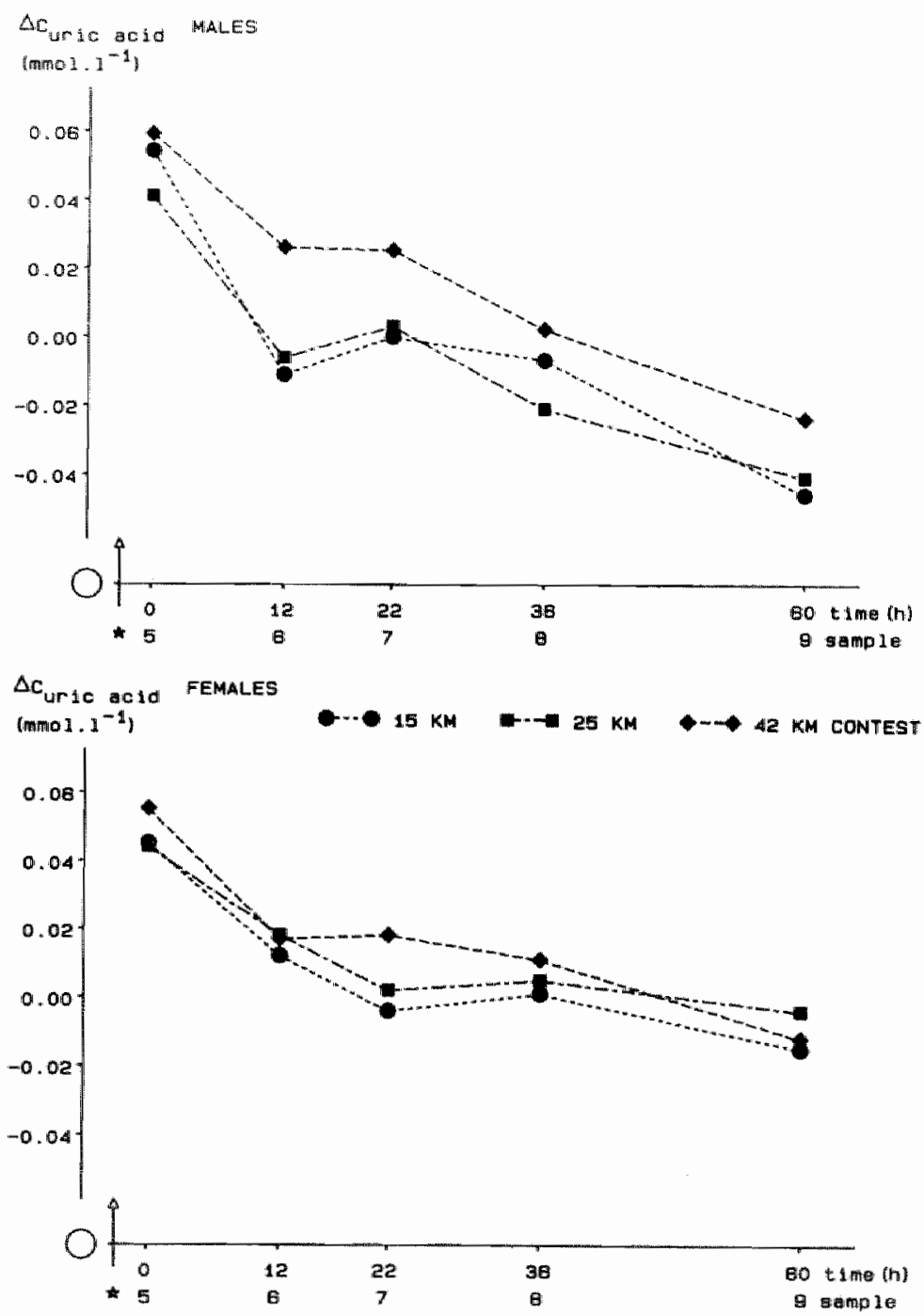

Fig. 4.1.4 Time course of delta urlc acld concentration in plasma after the contests; see Table 4.1.1. The values at $t=0$ were determIned In plasma obtallned 4-6 h (sample 5) after the contest. 


\section{Training adaptation}

No changes in urea concentration (basic level) were observed during the whole study neither in males nor in females, despite the increasing amount of training. The basic level of the creatinin concentration in plasma (mean value of sample 2 and 4) had decreased in the period between the 15 and the $25 \mathrm{~km}$ contest (M:p<0.001 and $F: p=0.074)$. No change of plasma uric acid concentration occurred due to the training (Tables 4.1.1 to 4.1.3). A significant increase with respect to basic level of the total protein concentration was observed in males during the training period between the 15 and $42 \mathrm{~km}$ contest $(p=0.002)$. In females there was no change of total protein plasma concentration during the whole training period. No change in plasma albumin concentration was demonstrated, neither in malles nor in females.

\section{Test-influences}

$15 \mathrm{~km}$ contest

In males there appeared to be a significant Increase of plasma urea concentration due to physical exercise tests on day 3 and day 5 ( $T_{2}$ and $\left.T_{3}\right)$ after the contest $(p<0.02)$. In temales there was no significant difference in urea concentration between values obtained after $\mathbf{T}_{1}, \mathbf{T}_{\mathbf{2}}$, and $\mathbf{T}_{\mathbf{3}}$.

\section{$25 \mathrm{~km}$ contest}

During the test protocol there was a significant increase of urea concentration in males after all the three exercise tests as compared with the pre-test values $(p=0.003 ; p=0.028$ and $p=0.002$, respectively). In females there was no significant increase of urea concentration after the physical exercise tests before and after the contest.

\section{$42 \mathrm{~km}$ contest}

Only after the physical exercise test $T_{3}$ after the marathon there was a significant increase of urea concentration in males $(p=0.002)$. In females there was no significant change in urea concentration after the physical exercise tests before and after the $42 \mathrm{~km}$ contest.

\section{Changes in plasma concentration due to physical exercise tests} before and after the three contests

In males the change in plasma urea concentration due to the exercise test $T_{2}$ after the $15 \mathrm{~km}$ contest (delta $U T_{2}$ ) was larger than that due to the exercise test $T_{\text {, }}$ before the $15 \mathrm{~km}$ contest (delta $U T_{1} ; p=0.02$ ). The same holds for delta $U T_{3}$ with respect to delta $U \mathbf{T}_{1}$, but this difference was not statistically significant $(p=0.07)$. For the marathon delta $U T_{2}$ was larger than delta $U T_{3}$ $(p=0.05)$. 
Plasma albumin and total protein

Data are presented in Table 4.1.2. The mean value of plasma albumin and total protein of sample 2 and 4 before each contest was used as reference value to evaluate the contest influences (Flg. 2.2). Sample 3 was used as reference to evaluate the values of the samples taken in the evening during the test protocol.

\section{$15 \mathrm{~km}$ contest}

Due to the $15 \mathrm{~km}$ contest in males the albumin concentration had significantly decreased in the samples $8,9,11,12,14$ and 15 taken in the morning $(p<0.001)$ when compared to the chosen reference value. The plasma albumin concentration in sample 7 and 10 had significantly decreased when compared to the concentration in sample 3 ( $p<0.002)$. In females the course of plasma albumin concentration was quite similar (for samples taken in morning $p<0.02$ and in the evening $p<0.03$ ), the concentration in sample 9 and sample 7 had not changed significantly.

No significant changes were observed in the plasma total protein concentration during the whole test protocol either in males or females.

\section{$25 \mathrm{~km}$ contest}

In males a significant increase in plasma albumin concentration was shown in sample $6(p<0.001)$ when compared to the reference value. A significant decrease of the plasma concentration with respect to the reference value was shown in sample $8,9,11$ and $12(p<0.02)$. When the concentrations of samples, taken in the evening, were compared to the concentration in sample 3 a significant increase was observed in sample $5(p=0.009)$ and a silgnificant decrease in sample $7(p=0.002)$. In females there was only a significant decrease of plasma albumin concentration in sample 8 compared to the reference vallue.

In hardly any samples significant changes were observed in the plasma total protein concentration during the whole test protocol, with the exception of a decreased plasma total protein concentration in sample 7 and 10 compared with sample $3(p<0.04)$.

\section{$42 \mathrm{~km}$ contest}

In males a significant increase in plasma albumin concentration was shown in sample $6(p<0.001)$ and a significant decrease in samples $8,9,12$ and $14(p<0.003)$ when compared to the chosen reference value. When compared to sample 3 a signiflcant increase was shown In sample 5 and a significant decrease in sample 10. In females a significant increase in plasma albumin concentration was shown in sample $6(p<0.01)$ and a significant decrease in samples $9,11,12$ and 14 ( $p<0.003$ ) when compared to the chosen reference value.

In males total protein concentration had significantly Increased in sample $6(p=0.0001)$ and decreased in samples $9_{y} 11,12$ and 14 $(p<0.001)$ when compared to the reference value. In females total protein concentration had significantly increased in sample 6 $(p=0.011)$ and decreased in samples 11,12 and $14(p<0.05)$ when compared to the reference value. 
Table 4.1.2 Plasma allbum and total proteln concentrations before and after the 15,25 and $42 \mathrm{~km}$ contest

\begin{tabular}{|c|c|c|c|c|c|c|c|c|}
\hline & $\begin{array}{l}\text { Males } \\
\text { Albumin } \\
\text { mean }\end{array}$ & sd & $\begin{array}{l}\text { Total } \\
\text { mean }\end{array}$ & $\begin{array}{l}\text { prote in } \\
\text { sd }\end{array}$ & $\begin{array}{l}\text { Females } \\
\text { Album In } \\
\text { mean }\end{array}$ & s.d & $\begin{array}{l}\text { Total } \\
\text { mean }\end{array}$ & $\begin{array}{l}\text { proteln } \\
\text { sd }\end{array}$ \\
\hline $1 \mathrm{~A}$ & 41 & 3 & 73 & 4 & 41 & 4 & 74 & 5 \\
\hline B & 43 & 2 & 76 & 4 & 42 & 6 & 77 & 4 \\
\hline C & 43 & 2 & 77 & 5 & 44 & 4 & 78 & 6 \\
\hline $2 A$ & 42 & 4 & 74 & 3 & 42 & 3 & 73 & 3 \\
\hline B & 42 & 3 & 76 & 4 & 42 & 4 & 76 & 5 \\
\hline C & 41 & 3 & 75 & 4 & 43 & 3 & 75 & 6 \\
\hline $3 A$ & 44 & 3 & 75 & 4 & 45 & 5 & 77 & 4 \\
\hline B & 44 & 2 & 77 & 4 & 43 & 4 & 78 & 4 \\
\hline C & 43 & 2 & 74 & 4 & 43 & 3 & 78 & 4 \\
\hline $4 A$ & 42 & 3 & 73 & 3 & 42 & 4 & 73 & 5 \\
\hline $\mathrm{B}$ & 41 & 2 & 76 & 5 & 41 & 4 & 76 & 6 \\
\hline$c$ & 42 & 2 & 77 & 5 & 42 & 3 & 76 & 4 \\
\hline $5 A$ & 45 & 3 & 76 & 4 & 45 & 4 & 76 & 6 \\
\hline$B$ & 45 & 2 & 78 & 3 & 44 & 5 & 78 & 8 \\
\hline C & 47 & 5 & 81 & 3 & 46 & 4 & 80 & 6 \\
\hline $6 \mathrm{~A}$ & 41 & 3 & 74 & 3 & 41 & 3 & 74 & 4 \\
\hline $\mathbf{B}$ & 43 & 2 & 76 & 4 & 42 & 4 & 77 & 4 \\
\hline$c$ & 45 & 3 & 79 & 5 & 45 & 4 & 78 & 6 \\
\hline $7 A$ & 41 & 3 & 75 & 3 & 42 & 4 & 77 & 3 \\
\hline B & 42 & 2 & 75 & 4 & 40 & 3 & 76 & 5 \\
\hline C & 43 & 3 & 76 & 4 & 43 & 5 & 77 & 5 \\
\hline$B A$ & 40 & 3 & 74 & 4 & 38 & 2 & 74 & 4 \\
\hline B & 40 & 2 & 73 & 5 & 39 & 3 & 75 & 4 \\
\hline c & 40 & 3 & 75 & 4 & 42 & 3 & 76 & 6 \\
\hline 9A & 41 & 3 & 73 & 3 & 41 & 3 & 73 & 5 \\
\hline B & 41 & 2 & 75 & 3 & 41 & 3 & 75 & 4 \\
\hline C & 41 & 3 & 75 & 5 & 42 & 2 & 75 & 6 \\
\hline IOA & 42 & 3 & 74 & 4 & 41 & 4 & 75 & 5 \\
\hline B & 43 & 2 & 75 & 4 & 43 & 4 & 78 & 5 \\
\hline$c$ & 42 & 2 & 77 & 6 & 41 & 2 & 76 & 4 \\
\hline $11 \mathrm{~A}$ & 40 & $\overline{3}$ & 74 & 4 & 39 & 4 & 74 & 4 \\
\hline $\mathbf{B}$ & 41 & 2 & 74 & 3 & 40 & 4 & 76 & 5 \\
\hline$\vec{c}$ & 42 & $\overline{2}$ & 74 & 5 & 40 & 3 & 74 & 6 \\
\hline $12 \mathrm{~A}$ & 40 & 3 & 74 & 5 & 40 & 3 & 74 & 3 \\
\hline B & 41 & 2 & 75 & 3 & 41 & 4 & 77 & 6 \\
\hline$c$ & 40 & 3 & 75 & 4 & 40 & 3 & 74 & 7 \\
\hline $13 A$ & 41 & 3 & 74 & 4 & 42 & 5 & 76 & 5 \\
\hline B & 43 & 2 & 76 & 3 & 43 & 4 & 78 & 5 \\
\hline$c$ & 42 & 2 & 76 & 5 & 42 & 2 & 77 & 4 \\
\hline $1.4 A$ & 40 & 3 & 73 & 4 & 39 & 4 & 73 & 4 \\
\hline 8 & 40 & 2 & 74 & 3 & 40 & 4 & 76 & 6 \\
\hline C & 41 & 2 & 75 & 5 & 39 & 3 & 74 & 4 \\
\hline $15 \mathrm{~A}$ & 40 & 3 & 72 & 4 & 39 & 5 & 73 & 5 \\
\hline$B$ & 40 & 2 & 74 & 3 & 41 & 3 & 78 & 6 \\
\hline$c$ & 40 & 2 & 73 & 3 & 42 & 3 & 75 & 4 \\
\hline
\end{tabular}

Mean values \pm sd $\left(\mathrm{g} . \mathrm{1}^{-1}\right)$ of album In and total proteln are given of the samples before and after the $15(\mathrm{~A})$, the $25(\mathrm{~B})$ and the 42 lim contest (C). 


\section{Gender differences}

Mean plasma creatinin concentration was significantly higher in males than in females for all the plasma samples $(p<0.02)$. However, except for $T_{2}$ after the $42 \mathrm{~km}$ contest, there were no differences between males and females with respect to the changes in creatinin concentration due to the physical exercise tests before and after the contests $(p<0.01)$.

The changes in uric acid concentration due to the exercise tests (delta UA $T$ ) before and after contests were larger in males than in females:

$15 \mathrm{~km}$; for $T_{11}: p<0.001$, for $T_{2:} p<0.003$ and for $T_{3}: p<0.005$.

$25 \mathrm{~km}$; for $T_{1}: p<0.001$, for $T_{2}: p<0.001$ and for $T_{3}: p=0.007$.

$42 \mathrm{~km}$; for $T_{1}: p>0.1$, for $T_{2}: p>0.1$ and for $T_{3}: p=0.030$ ).

The differences between the two sexes with regard to the concentrations of uric acid disappeared temporarily after each contest: $15 \mathrm{~km}$ : after 3 days; $25 \mathrm{~km}$ : after 6 days; $42 \mathrm{~km}$ after 5 days.

The increase of urea concentration induced by contests appeared to be independent of sex, but the decrease between day 1 and day 3 after the $42 \mathrm{~km}$ contest was significantly slower in males than in females $(p=0.018)$.

During the test protocols of the 3 contests there were no significant differences between males and females in the concentrations of albumin and total protein.

\section{Discussion}

Factors which may have attributed to changes in concentrations are dehydration and a reduced blood flow in the splanchnic area and through the liver and the kidneys during physical exercise (2,9, $10,11)$.

Most authors apply correction factors $(1,5,11)$ to the measured concentration values to correct for dehydration. The factors used are usually based on observed changes in hematocrlt or in total protein concentration.

We decided not to use any correction factor for the following reasons.

- The first blood sample in which determinations were performed was drawn at least $5 \mathrm{~h}$ after exercise test or contest. it is. well known from literature that plasma volume reaches preexercise values already one hour after a maximal treadmill test (18).

- Hematocrit as well as total protein concentration may themselves vary under the influence of exercise and will thus be less suited to serve as a correction factor for the calculations of hemoconcentration.

- When using correction factors calculated from total protein changes in this study, the interpretation of the results was not influenced in any way.

A reduced blood flow in the splanchnic area and through the liver and kidneys might influence kidney and liver functions. However, when looking at the concentration of creatinin and uric acid In 
plasma after the 15,25 and $42 \mathrm{~km}$ contests in the course of time (Flgs. 4.1.3 and 4.1.4), it appears that the concentration changes are similar for all three contests, indicating that the kidney function is relatively stable and not influenced by an increase of physical stress. The same holds for liver functions as can be concluded from the only slight mean rise in the concentration (max. $6 \mathrm{U.l}^{-1}$ ) of Allat even after the marathon (Chapter 5.3 ; p.105)

The observed considerable difference in clearing rate between urea and creatinin (Figs. 4.1.2 and 4.1.3) may be explained by the fact that urea and uric acid have to be formed by the llver first and then excreted, while creatinin comes straight from muscle metabolism and only has to be cleared by the kidneys $(12,26)$.

Plasma albumin and total protelin concentration appeared to be higher in the samples taken in the evening before the contests in comparison with the samples taken in the morning before the contests $(0.0001<p<0.05)$. The differences in the plasma concentration of the samples taken in the morning and the evening were possibly caused by plasma volume changes during the day or orthostatic influence and not due to the physical stress of the exercise tests. From a pllot study of 10 volunteers (blood taken under similar conditions) it appears that the mean plasma albumin concentration in the morning was $40 \pm 1 \mathrm{g.t-1}$ and in the evening $42 \pm 2 \mathrm{g.1}-1$. The difference in concentrations was significant $(p=0.017)$. The data concerning plasma total protein concentrations before and after the exercise test before the contests in the morning were $67 \pm 2 \mathrm{g.l-1}$ and in the evening $69 \pm 4(p=0.043)$ in the pllot study. The volunteers did not exercise on the evening betore and during the day of blood sampling.

Both sexes have a similar course of the plasma concentration. However, In females there was a slower and a lower decrease of plasma albumin concentration than was demonstrated in males. The Increment of urea concentration after prolonged exercise is similar to that reported In the literature, although the urea concentration was measured soon after the contests or the physical exerclse $(6,16,21,22,23)$. However, in males and females the degree of change in concentration depends on the contest dlstance (Flg. 4.1.2). Moreover in males the pattern of the concentration-time course in the 25 and $42 \mathrm{~km}$ contests is different from this pattern in females; In males the concentration flrst Increases and starts to decrease only after about $24 \mathrm{~h}$. Nevertheless 2.5 days after each contest the urea concentration is back to the pre-contest level.

For creatinin the plcture is completely different; there is an increase in plasma concentration for about 1-2 days only after running a marathon.

For uric acld the concentration changes are transient and not related to the degree of exerclse (Table 4.1.1).

In the course of the training period, the only change observed was the decrease in the plasma creatinin concentration in spite of the increase of training load. A possible reason for this decrease was an Increased clearance of the creatinin through a greater blood flow (Chapter 5.3). 
In spite of the increase in training load during the present study the plasma urea concentrations showed a constant level and did not differ from normal values. This indicates that the metabolism and clearance of urea increase with the physical stress tolerance. It is generally accepted that trained people have a hilgher concentration than the normal basic level, because the frequency and intensity of training is high and the body is stressed constantly $(6,16,21)$. summarizing the data on plasma concentrations of urea, creatinin and uric acid in training and after physical tests and contests, it can be concluded that an increased urea concentration in combination with an increased creatinin concentration up to two days after considerable physical stress indicates a situation of disbalance between physical stress and physical stress tolerance; plasma uric acid concentration does not add information in this situation.

Considering the gender differences, the data show that males and females have simillar metabolic responses due to physical stress but males and females show differences in the pattern of decrease after a very strong physical stress situation especially of plasma urea concentration (Figs. 4.1.2 to 4.1.4). This indicates that in males the catabolic state persists longer than in females. The larger and earller decrease of the plasma albumin concentration in males compared to that in females after prolonged exercise can be explained from a longer persisting catabolic state. The argument that a decrease of albumin concentration seems to have a physiological cause is thus consolidated, since a larger decrease appeared in males than in females (3). There is for instance a significant negative correlation $(p=0.024)$ in males between the test performance in the physical exercise test $T_{2}$ after the $42 \mathrm{~km}$ contest and the plasma urea concentration before the exerclse test $T_{2}$ (sample 9). In females there was no significant correlation between the test performance of the physical exercise test $T_{2}$ and the plasma urea concentration before the exercise test. Moreover in the other contests $(15 \mathrm{~km}$ and $25 \mathrm{~km}$ ) there was an increasing correlation between the test performance and the plasma urea concentration in males.

It may be concluded that the gender differences observed in plasma concentrations and in the pattern of decrease of plasma concentrations particularly those of urea, indicate that females will recover more quickly from a physical stress situation than males.

\section{References}

1 Beaumont van W.: Red cell volume with changes In plasma osmolarity during maximal exercise. $J$ Appl Physiol 35:47-50, 1973.

2 Brandenberger G., Candas V., Follenius M., Libert J.P., Kahn J.M.: Vascular fluid shifts and endocrine responses to exercise in the heat. Effect of rehydration. Eur $J$ Appl Physiol 55:123-129,1986.

3 Cerny F.: Protein metabolism during two hour ergometer exercise. Proceedings of the second international symposium on biochemistry of exercise Magglingen. Howald $H_{\text {. and }}$ 
Poortmans J.R “ (ed), Birkhăuser Verlag Basel. 1973, pp 232-237.

4 Dohm G.L., Hecker A.L., Brown W.E., Klain G.J., Puente, Askew E.W., Beecher G.P.: Adaptation of protein metabolism to endurance training. Increased amino acid oxidation in response to training. Blochem $J$ 164:705-708,1977.

5 Hagan R.D., Diaz F.J., McMurray R.G., Horvath S.M.: Plasma volume changes related to posture and exercise. Proceedings of the soclety for experimentall biology and medicine. 165: 155-160,1980.

6 Haralambie G., Berg A,": Serum urea and amino nitrogen changes with exercise duration. Eur J Appl Physiol 36:39-48, 1976.

7 Haralamble G., Senser L., Sierra-Chavez R.: Physiological and metabollc effects of a $25 \mathrm{~km}$ race in female athletes. Eur J Appl Physiol 47:123-131,1981.

8 Haralambie $G_{\text {. }}$, Senser L.: Metabolic changes in man during long-distance swimming. Eur J Appl Physiol 43:115-125,1980.

9 Harrison M.H., Graveney M.J., Coochrane L.A.: Some sources of error in the calculation of relative change in plasma volume. Eur J Appl Physiol 50:13-21,1982.

10 Hill D.W., Hill J.S., Grisham S.C., Zauner C.W.: Plasma volume response to exercise on five consecutieve days. J Sports Med 27:6-10,1987.

11 Hinghofer-Szalkay H., Greenleaf J.E.: Continuous monitoring of blood volume changes in humans. J Appl Physiol 63(3): 1003-1007,1987.

12 Hoffman W.S. (ed): The blochemistry of clinical medicine. $4^{\text {th }}$ edition, Year Book Medical Publishers, Chicago.

13 Jackson A.A., Picou D., Landman J.: The non-invasive measurement of urea kinetics in normal man by a constant infusion of $10 \mathrm{Ni} \times \mathrm{N}$-urea. Human nutrition: clinical nutrition 38C:339-354,1984.

14 Kaiser V., Janssen G.M.E., Wersch van J.W.J.: Sweat excretion of Iron in long distance runners. Annals of Clin Blochem, Suppl. 2:60,1987.

15 Lemon P.W.R., Nagle F.J.: Effects of exercise on protein and amino acid metabolism. Med Scl Sports Exerc 13(3):141-149, 1981.

16 Lorenz $\boldsymbol{R}_{\text {s, }}$ Gerber G.: Harnstoff bel körperlichen Belastungen: Veränderungen der Synthese, der Blutkonzentration und der Ausscheidung. Med u Sport 19:240-247,1979.

17 Maron M.B., Horvath S.M., Wilkerson J.E.: Blood blochemical alterations during recovery from competitive marathon running. Eur J Appl Physiol 36:231-238,1977.

18 Novosadova J.: The changes In hematocrit, hemoglobin, plasma volume and proteins during and after different types of exerclse. Eur ل Appl Physiol 36:223-230,1977.

19 Payne R.B.: Creatine clearance: a redundant clinical investigation. Ann Clin Blochem 23:243-250,1986.

20 Poortmans J." Proteln metabollsm: effects of exercise and training. Med Sport 13:66-76,1981. 
21 Refsum H.E., Strömme S.B.: Urea and creatinine production and excretion in urine during and after prolonged heavy exercise. Scand J Clin Lab Invest 33:247-254,1974.

22 Riley W.J., Pyke F.S., Roberts A.D., England J.F.: The effect of long-distance running on some biochemical variables. Clin Chim Acta 65:83-89,1975.

23 Röcker L., Kirsch K.A., Stoboy H.: Plasma volume, albumin and globulin concentrations and their intravascular masses. A comparative study in endurance athletes and sedentary subjects.Eur J Appl Physiol 36:57-64,1976.

24 Schuster von H.G., Neumann G., Buhl H.: Kreatinin- und Kreatinveränderungen im Blut bei Körperlicher Belastung. Med Sport 19(8):235-240,1979.

25 Viru A., Körge P.: Metabolic processes and adrenocortical activity during marathon races. Int $Z$ angew Physiol 29: 173-183,1971.

26 Walser M., Bodenlos L.J.: Urea metabolism in man. pp. 1617-1626,1959.

27 Whiting P.H., Maughan R.J., Miller J.D.B.: Dehydration and serum biochemical changes in marathon runners. Eur $\mathrm{J}$ Appl Physiol 52:183-187,1984.

28 Wolfe R.R., Goodenough R.D., Wolfe M.H., Royle G.T., Nadel E.R.: Isotopic analysis of leucine and urea metabolism in exercising humans. J Appl Physiol 52(2):458-466,1982. 
4.2 Changes in basal plasma testosterone, cortisol and dehydroepiandrosterone sulphate in previously untrained males and females preparing for a marathon

\section{Introduction}

Today there is no doubt that skeletal muscle is a target organ for testosterone $(28,31,34,39)$ and cortisol $(27,31,32)$. Growth and hypertrophy in this tissue is, among others, induced $(20,21)$ by testosterone (T) and counteracted $(27,31,32)$ by cortisol (C).

Physical exercise has been reported to be a strong stimulus for changing the circulating levels of a wide variety of hormones (19). Consequently, the homeostasis of the endocrine system may be disturbed for hours or even days after exercise provided that the exercise is of sufficient duration and intensity $(1,15,22)$. In males, for example, this may lead to significantly lowered plasma $T$ levels $(15,22)$.

Unlike in males, in females plasma $T$ levels have been reported to increase linearly with exercise $(24,25,26,44)$, whereas no data are available about the responses of the endocrine system in the hours and/or days after an acute prolonged exercise. The role of the pituitary/adrenal/gonadal axis in periods of exercise stress is still very vaguely known. Unlike in acute or short-term mental stress, long-term stress leads to elevated ACTH secretion $(40,42)$ and consequently to increased $\mathrm{C}$ production. However, the situation during and atter exercise seems to be much more complex. In malles, for example, the cortisol responses to prollonged physical exercise have been reported to be quite variable. Some investigators found increments of 3-4 times the pre-exercise values $(13,36)$, whereas others (41) found a decrement. This variability of the $C$ responses to exercise makes the value of this hormone as a stress marker questionable and urges to search for another one.

Recently Bonen and Keizer (6) were able to show that the plasma concentration of dehydroepiandrosterone sulphate (DHEAS), a steroid which is exclusively derived from the adrenal cortex, remained elevated in the $2 \mathrm{~h}$ after a marathon. Hence, it may be that this hormone is a more reliable stress marker than $\mathrm{C}$. In conclusion, there is some evidence that an increased $C / T$ ratio will occur after prolonged physicall exercise, which might hamper the anabolic processes in skeletal muscle. However, there are very few prospective studies supporting this hypothesis, whereas no data are available about the hormonal responses in females. Especially, data about the time course of changes in plasma $T$ and $C$ levels after strenuous long lasting exercise and the reaction on physical conditioning hereupon are completely lacking. 
The objectives of this study therefore were the following.

- To establish the effects of an endurance training programme on basal plasma $T, C$ and DHEAS levels.

- To investigate the effects of a 15, 25 and $42 \mathrm{~km}$ (marathon) contest on the levels of the mentioned hormones.

- To establish the effects of a short-term treadmill run in the days after the contests on homeostasis of the endocrine system.

\section{Materials and methods}

\section{Subjects}

The 25 male and 11 female volunteers of the treadmill group (TG) served as subjects after informed consent was obtained. Their average height, weight, age, $\%$ body fat and maximal work capacity are shown in Table 2.3 (p. 27).

When entering the study all subjects were untrained as defined in Chapter 2. Data on basal hormone levels as a response to training and short-term exercise were collected around the time the subjects were able to run the 15,25 and $42 \mathrm{~km}$ contest, respectively since plasma $T$ and $C$ levels show a diurnal rhythm $(8,9,43)$, blood samples were obtained in the morning and the late afternoon as well.

Samples $3,7,10$ and 13 were taken at 6 p.m., whereas blood samples $2,4,6,8,9,11,12$ and 14 were obtained after an overnight fast in the morning between 8 and 10 a.m. Blood sample 5 (first after a contest) was obtained between 8 and 12 p.m. (Fig.4.2.1).

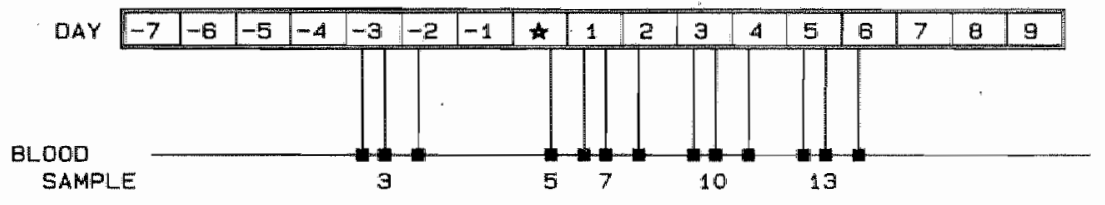

TAEADMILL GIAOUP

FIg. 4.2.1 TIme schedule of the protocol before and after the three cantests with speclal reference to the time intervals for blood sampl IIng.

In Chapter 2 (p. 33) materials, methods and procedures concerning this part of the investigation have been described. For the temales the contests were planned between week 2 and 3 of the menstrual cycle.

\section{Results}

The blood sampling procedure employed in this investigation enabled us to get insight into the effects of the preceding exercise and changes in diurnal rhythm as well. 
The results are depicted in Table 4.2 .1 and Figs. 4.2 .2 (testosterone), 4.2 .3 (cortisol) and 4.2 .4 (DHEAS).

The present investigation has revealed the following results.

\section{Testosterone}

The different contests $(15,25$, and $42 \mathrm{~km})$ elicited signiticant and simillar decrements in plasma $T$ llevels. In males the decrease was 8.1

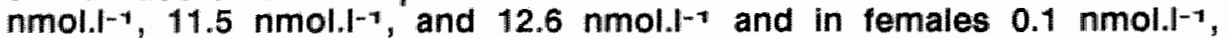
$0.5 \mathrm{nmol.1}^{-1}$, and 0.1 inmol. I- $^{-1}$ (Table 4.2.1), respectively. The decrease of plasma testosterone concentration in malles due to the $42 \mathrm{~km}$ contest was significantly larger than the decrease due to the $15 \mathrm{~km}$ contest $(p=0.007)$ and there was a tendency to a larger decrease after the $25 \mathrm{~km}$ contest in comparison with the $15 \mathrm{~km}(p=0.062)$. The longer the run, the more time it took before the testosterone concentration in males returned to pre-contest levels $(15 \mathrm{~km}$ contest, sample 2 to $6 \mathrm{p}>0.05 ; 25 \mathrm{~km}$ contest, sample 2 to $6 \mathrm{p}=0.008$ and $42 \mathrm{~km}$ contest sample 2 to 6 , sample 2 to 8 and sample 2 to $11 p=0<0.001, p=0.017$ and $p=0.046$, respectively) (Fig.4.2.2). A similar behaviour was observed in plasma samples of males taken in the afternoon. In the females there was no clear relation between plasma $T$ levels and the contests, although there was a decrease of the testosterone concentration of sample 2 to 6 in $25 \mathrm{~km}$ and $42 \mathrm{~km}$ contest of $0.4 \mathrm{nmol} . \mathrm{I}^{-1}$ and $0.3 \mathrm{nmol} . \mathrm{I}^{-1}(\mathrm{p}=0.066$ and 0.066 , respectivelly). No significant difference was demonstrated between the testosterone concentration even of sample 5 to 2 after the $15 \mathrm{~km}$ and $42 \mathrm{~km}$ contests.

The concentration of testosterone in the afternoon of the females had significantly decreased after the marathon in contrast with the $15 \mathrm{~km}$ and $25 \mathrm{~km}$ contest $(p=0.025)$, when comparing sample 3 with 10 . Unlike in females, in males an increase in basal $T$ levels was noticed in sample 2 before the 25 and $42 \mathrm{~km}$ as compared to the 15 $\mathrm{km}$ contest $(p=0.031$ and $p=0.022)$.

\section{Cortisol}

Basal plasma cortisol levels did not change due to the training. Plasma levels of this hormone had significantly increased in the hours immediately after the runs. The highest values in male runners were measured after the marathon run (148\% of base llne values). The next day the plasma $C$ levels were not different from the pre-contest values, except for those after the $25 \mathrm{~km}$ contest, which were llowered $(p=0.003)$. Plasma cortisol response due to the contests in the female runners seemed to be somewhat different from the response in male runners (Fig. 4.2.3). In females there was no significant difference in cortisol concentrations after all

the three contests, when comparing sample 5 with 2 . In males there was a significant decrease after the 15 and $25 \mathrm{~km}$ contests $(p=0.0001$ and $p=0.003$, respectively), when comparing sample 5 with 2 , but no difference after the marathon (Flg. 4.2.3).

In addition, the plasma cortisol levels in the afternoon had only increased significantly in males after the 15 and $42 \mathrm{~km}$ contests in malles, when comparing sample 5 with sample $3(p=0.067, p>0.1$ and $p=0.001)$. The increase of cortisol concentration in the afternoon 
Table 4.2.1 Plasma concentration of testosterone, cortisol and DHEAS before and after the three contests

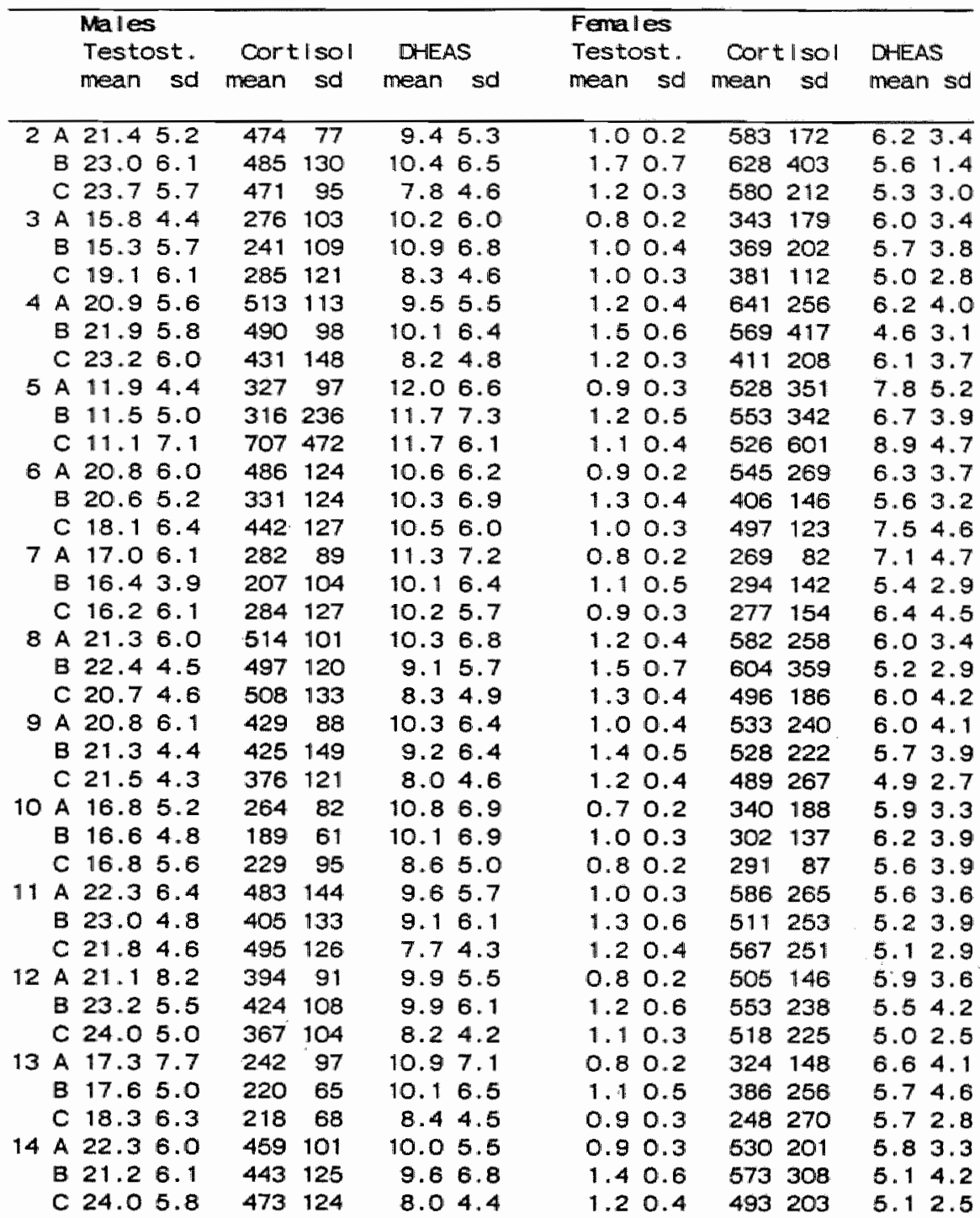

Mean values \pm sd of testosteron (mol. $1^{-1}$ ), cort $\mid \mathrm{sol}$ ( $\mathrm{mol} . \|^{-1}$ ) and DHEAS ( $/ \mathrm{mol} . \mathrm{I}^{-1}$ ) are gIven of the samples before and after the 15 (A), the 25 (B) and the $42 \mathrm{~km}$ contest (C). 
(sample 5 to 2) after the $42 \mathrm{~km}$ contest had changed significantly only in males in comparison with the decrease after the $15 \mathrm{~km}$ and $25 \mathrm{~km}$ contest (15km vs $42 \mathrm{~km} p=0.002$ and $25 \mathrm{~km}$ vs $42 \mathrm{~km} p=0.004)$. The difference of plasma cortisol concentration, when comparing sample 6 with 2 , showed a signifficant increase between the 15 and $25 \mathrm{~km}$ contest for males and females $(p=0.026$ and $p=0.047$, respectively).The plasma $\mathrm{T}$ and $\mathrm{C}$ levels followed a remarkably similar pattern with the exception of the values after the contests.

\section{DHEAS}

$\overline{B o t h}$ in males and females, the plasma levels of this hormone had increased significantly after the contests. The most pronounced increments occurred after the marathon run, a less pronounced increase occurred after the $15 \mathrm{~km}$ and $25 \mathrm{~km}$ contest. In the male runners the plasma levels of DHEAS remained increased for another $36 \mathrm{~h}$ after the marathon. However, the increase of DHEAS plasma concentration was significantly llower after the $15 \mathrm{~km}$ and $25 \mathrm{~km}$ contest in contrast with the $42 \mathrm{~km}$ contest, comparing 5 to 2 , both in males and in females (15km vs $42 \mathrm{~km} p=0.020$ and 0.052 , respectively) and (25km vs $42 \mathrm{~km} p=0.003$ and 0.012 , respectively). After training, the basic level of DHEAS was lowered both in the males and females $(15 \mathrm{~km}$ vs $25 \mathrm{~km}, p=0.064$ and $p>0.1$, respectively and $15 \mathrm{~km}$ vs $42 \mathrm{~km}, \mathrm{p}=0.012$ and $\mathrm{p}=0.007$ ). 


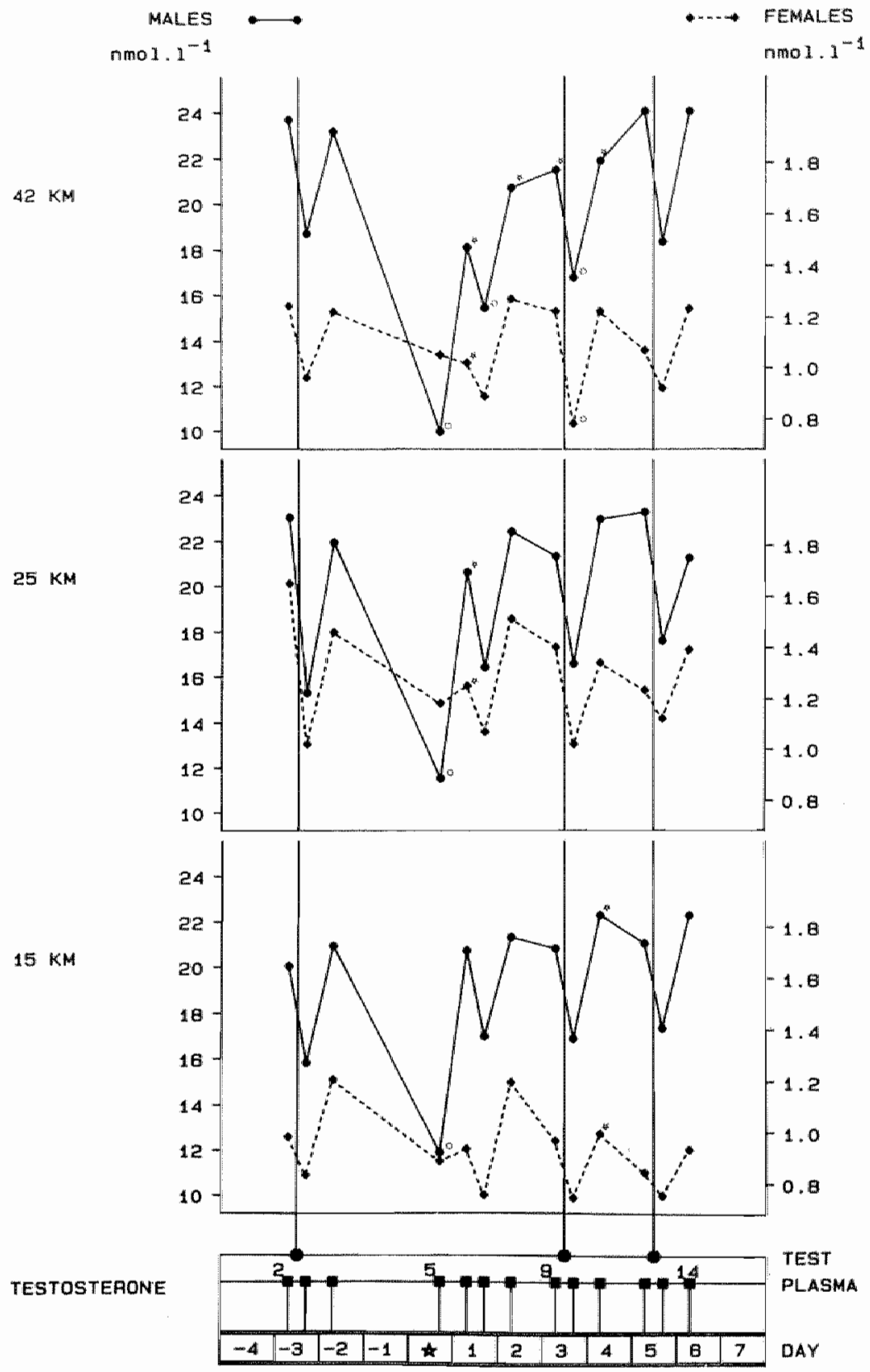

Flg. 4.2.2 Plasma testosterone ( $\left.\mathrm{mol} . \mathrm{l}^{-1}\right)$ in males and females before and after a 15, 25 and $42 \mathrm{~km}$ contest. and represent signiflcant differences from plasma sample 2 and 3 , respect Ively.

* represents the 15,25 or $42 \mathrm{~km}$ contest 


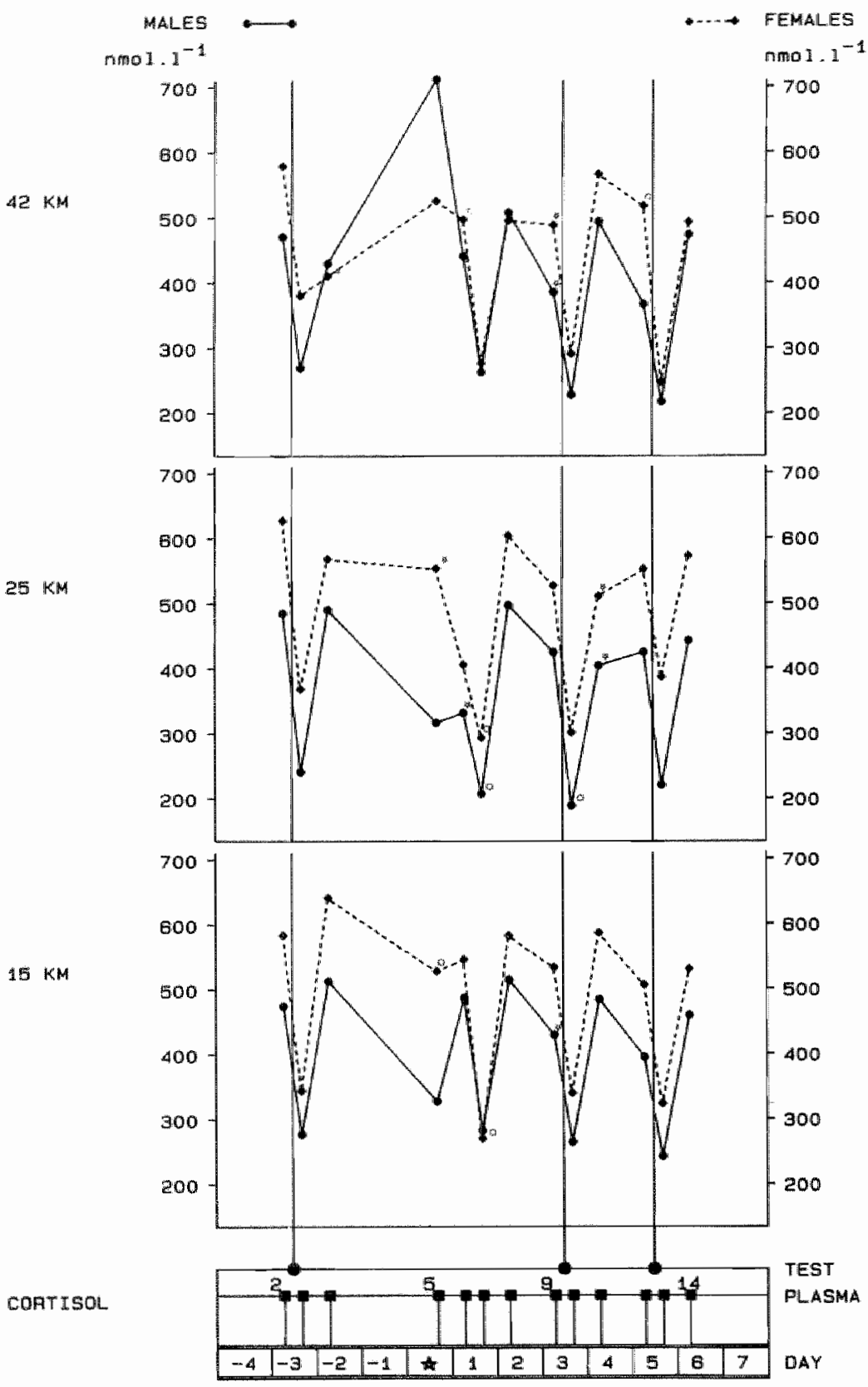

FIg. 4.2.3 Plasma cortisol ( $\mathrm{mol} . \mathrm{1}^{-1}$ ) in males and females before and after 15,25 and $42 \mathrm{~km}$ contest. and represent signlficant differences from plasma sample 2 and 3 , respect Ively.

* represents the 15,25 or $42 \mathrm{~km}$ contest 


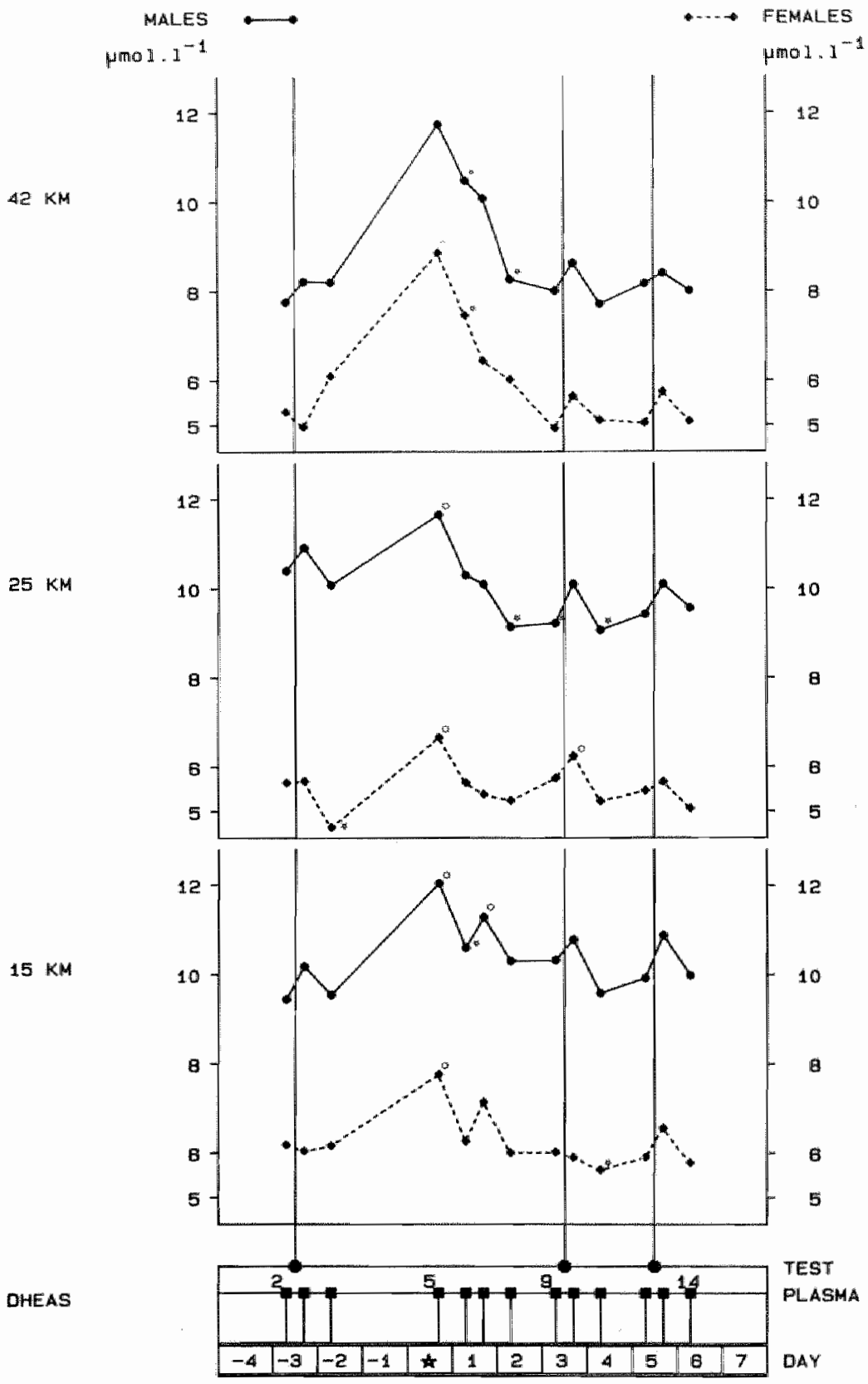

FIg. 4.2.4 Plasma DHEAS (umol. $1^{-1}$ ) in males and females before and after a 15,25 and $42 \mathrm{~km}$ contest. and represent significant differences from plasma sample 2 and 3 , respect lvely.

- represents the 15,25 or $42 \mathrm{~km}$ contest 


\section{Discussion}

Testosterone

In the present investigation, the testosterone pattern in males was quite similar in the three experimental conditions. In all 3 contests, the $T$ levels were between 11-12 nmol.|l-1 lower than the starting values $6 \mathrm{~h}$ after exercise cessation. The greatest relative changes, however, were observed in males after the marathon (about $53 \%$ ). Thereafter the testosterone levels in samples 2 (in the morning) and 3 after $T_{1}$ (in the afternoon) increased during the observation period between the $15 \mathrm{~km}$ and $42 \mathrm{~km}$ contests. The pattern in the female volunteers was different with no clear reaction to the preceding exercise.

Both in male and female volunteers, it appeared that the treadmill runs were not able to elicit significant changes in the normal diurnal rhythm.

In males, decrements in $\mathrm{T}$ levels after exhaustive prolonged exercise have also been found by other investigators $(14,15,25,29,30)$.

Kuoppasallmi et all. (29) found a mean decrement of about $40 \%$ $6 \mathrm{~h}$ after exhaustive exercise of different intensities and duration. In the present study the decrease of testosterone concentration 6-7 $\mathrm{h}$ after the maximal treadmill tests ( $T_{1,}, T_{2}$ and $T_{3}$ ) compared to sample 2 in malles was calculated to be $20,20,18 \%$ before and after the $15 \mathrm{~km} ; 33,22,24 \%$ before and after the $25 \mathrm{~km}$ and 20 , 22, $24 \%$ before and after the $42 \mathrm{~km}$ contests (Fig. 4.2.1), respectively. In addition, the same investigators reported that the low levels of $T$ lasted for at least 3 days, which corroborates the data of Dufaux et al. (15), but partly disagrees with the data of the present investigation (15 km) and those of Morville et al. (35) who found a rapid return to base-line levels. The latter investigators also found that plasma $T$ levels were augmented 4 days after a $100 \mathrm{~km}$ run.

The results of the present investigation furthermore show that carefully conducted endurance training augments the basal $T$ levels, which is in line with the results of Kuoppasalmi and Adlercreutz (30) and Remes et al. (37), but disagrees with those of Fellmann et al. (16), who did not find any changes in $T$ levels after a 40 week endurance training programme. The discrepancy

between our results and those of Fellmann et al. (16) may be caused by the small number of subjects in case of Fellman's study and different experimental designs as well. In the present study, the subjects refrained from any exercise 3 days before the first treadmill run and the whole experimental period thereafter as well, except for the physical exercise tests and the contest.

The available information about female responses to training is very scarce. In a cross-sectional study Dale et al. (12) found higher $\mathrm{T}$ levels in runners as compared to sedentary controls, whereas Keizer et al. $(24,25)$ found higher $T$ levels in sedentary controls than in highly trained marathon runners.

The differences between the results of the mentioned investigations are hard to reconclle. Possible explanations could be the differences in phase in the menstrual cycle in which the experiments took place and the much greater intra-assay varlation coefficient at a level of 1 nmol. - $^{-1}$ as compared to the male levels. 
In addition, one has to bear in mind that, unlike in males, plasma $T$ in females is for the greater part derived from the adrenal cortex and peripheral conversion from androstenedione (2) and only for a small part from the gonads. Hence, it might be that in females estradiol is a better marker for short-term exercise induced pituitary-gonadal dysfunction than testosterone. Changes in the plasma concentration of hormones may be attributed to changes in secretion and/or degradation. Although it is has been proved, that the metabolic clearance rate of ovarian and testicular sterolds is decreased $(10,23)$ no data are avallable about the days after prolonged exercise, although the investigations of Casper et al. (11) imply that an increased clearance may play an important role. However, an increased production rate as has been reported in rats (30), may be another adaptive effect of endurance training leading to increased $T$ levels about 7 days after exhaustion exercise.

\section{Cortisol}

In the present investigation, the plasma cortisol pattern in the male volunteers (with the exception of the values directly after the marathon) was quite similar between the three experiments and closely resembled the $T$ pattern. Only the marathon elicited significant increments, whereas no changes occurred after the $25 \mathrm{~km}$ run and only a tendency $(p=0.07)$ for an increment after the $15 \mathrm{~km}$ run. In the females the pattern after the contests was different: after the $15 \mathrm{~km}$ run, cortisol levels were significantly ellevated, after the $25 \mathrm{~km}$ there was a tendency $(\mathrm{p}=0.06)$ for an increment, whereas no changes were observed after the marathon. In the morning after the contests decrements were sometimes observed (15 $\mathrm{km}$ and $25 \mathrm{~km}$ ), whereas after the marathon the afternoon values remained below the pre-contest levell.

In males, changes in plasma cortisol levels after exhaustive exercise have been found by several authors, although the results are inconsistent $(1,5,9,10,13,17,29,42)$. No data are available about cortisol responses in females. In males, increments in plasma cortisol levels after exercise have been found by several authors $(29,30,42,43)$. However, in all cases blood levels were normallized within 2-3 h after exercise cessation $(29,43)$ or were below $(33,42)$ pre-exercise values. Others (42), however, found decrements after' prolonged exercise. The dissimilarity in the results of the afore mentioned studies are probably attributable to the different types of exercise employed and the negligence of the normal diurnal rhythm as well. When we compare studies in which similar types of exercise have been employed as in the present study [Afar cited by Viru (44),33] it appears that cortisol llevels increase in the hours immediately after exercise, after which they may decline below control levels.

An explanation for these different responses is hard to provide, since changes in cortisol levels may be caused by changes in secretion and/or degradation rate. Bonen (5) was able to show, that cortisol excretion was augmented by exercise. Pokholentchuk [cited by Viru (44)] furthermore showed that the corticosterone content of the adrenal cortex of rats exposed to exhaustive endurance exercise remained elevated for 5 days. On the other hand, a diminished 
pituitary drive has to be considered, since Rivier and Valle (38) showed a decreased ACTH output after stimulation with corticotropin releasing factor. Hence, one might hypothesize, that the decreased cortisoll levels after the marathon as found in the female runners in the present investigation, might be attributed to this effect as well. This might decrease the amplitude of the pituitary/adrenal axis and impair physical performance. Hence, one might presume that the differences in cortisol responses to various types of exercise

in humans may be caused by changes in clearance as well as a decrease in ACTH secretion in response to corticotropin releasing factor.

\section{Dehydroeplandrosterone sulfate (DHEAS)}

One of the most interesting findings of the present investigation is the change in plasma DHEAS levels after prolonged exerclse. In contrast to the $T$ and $C$ responses, the DHEAS responses are quite similar between males and females. In both groups DHEAS had increased significantly after all three contests with no differences between the magnitude of these responses. Both in males and females, DHEAS levels remained elevated for 1 to 2 days after the marathon. Training elicited a decline in basal DHEAS levels in both groups. Data about plasma DHEAS responses are very scarce and where males are concerned completely lacking. In females, several authors found Increments after endurance exercise $(3,6,24,25,26)$. In only one Investigation (6) plasma DHEAS levels were determined after exercise cessation. These investigators also found marked Increments $2 \mathrm{~h}$ after a marathon run, whereas no decllne was observed compared to the values obtained right after the contest. However, Ronkainen et al. (39) did not find a difference in plasma DHEAS concentration in females after 6 months training.

The underlying mechanism of the increased DHEAS concentration is suggested to be increased secretion rather than decreased

clearance, since at rest the clearance is reported to be too low (4) to cause such dramatic elevations as observed in the present and the mentioned investlgations. This implies, that this hormone may be well used to monitor adrenal secretory activity. Thls enhanced secretion is probably due to an increased activation of the renin-angiotensin aldosterone system, since it is well documented that the renin levels increase with exercise (18). In conclusion, the present investigation has revealed, that a carefully conducted endurance training programme may stabilize the hormonal system, since we observed only minor changes in plasma $T$, cortisol and (to a lesser extent) DHEAS levels after a 15, 25 and $42 \mathrm{~km}$ contest, respectively. After all contests the treadmill tests coulld not ellcit any change In the normal diurnal changes of $T$ and cortisol. The different cortisol responses to exhaustive endurance exercise in males and females suggest that the pituitary/ adrenal axis is influenced differentially. Future research is needed to shed more light on this observation.

The elevated DHEAS levels furthermore suggest that despite normalized or lowered cortisol levels the adrenal cortex remained activated for several hours to days (dependent on the training status and/or the duration of the contest) after the contest. 


\section{References}

1 Aakvaag A., Opstad P.K.: Hormonal responenses to prolonged physical strain, effect of caloric deficlency and sleep deprivation, in Fotherby K., Pal S.B. (eds): Exercise Endocrinology. W. de Gruyter, Berlin, 1985, pp 25-46. Abraham G.E.: Ovarian and adrenal contribution to peripheral androgens during the menstrual cycle. J Clin Endocrinol Metab 39:340-346,1974.

3 Baker E.R., Mathur R.S., Kirk R.F., Landgrebe S.C., Moody L.O., Williamson H.O.: Pllasma gonadotropins, prolactin, and steroid hormone concentrations in female runners immediately after a long-distance run. Fert Steril 38:38-41,1982.

4 Bird C.E., Murphy J., Boroomand K., Finnes W., Dressel D., Clark A.F.: Dehydroepiandrosterone: Kinetics of metabolism in normal men and women. J Clin Endo Metab 47:818-823,1978. Bonen A.: Effects of exercise on the excretion rate of urinary free cortisol. J Appl Physiol 40:155-158,1976.

6 Bonen A., Keizer H.A.: Pltuitary, ovarian and adrenal hormonal responses during marathon running, in Keizer H.A. (ed):

Hormonal responses in women as a function of physical exercise and training. Int $J$ Sports Med B(suppl 3):161-167,1987.

7 Boyden T.W., Pamenter R.W., Stanforth P., Rotkis T., Wilmore J.H.: Sex steroids and endurance running in women. Fert Steril 39:629-632,1983.

8 Brandenberger G., Follenius M., Hietter B.: Feedback from meal-repeated peaks determines diurnal changes in cortisol responses to exercise. J Clin Endocrinol Metab 54:592-596, 1982.

9 Brandenberger G.:Cortisol responses to exercise and their interaction with diurnall peaks, in Fotherby K., Pal S.B. (eds): Exercise endocrinology. W. de Gruyter, Berlin, 1985, pp 47-64.

10 Cadoux-Hudson T.A., Few J.D., Imms F.d." The effect of exercise on the production and clearance of testosterone in well trained young men. Europ J Appl Physiol 54:321-325,1985.

11 Casper R.F., Wilkinson D., Cotterell M.A.: The effect of increased cardiac output on luteal phase gonadal sterolds: a hypothesis for runners amenorrhea. Fertil Steril $41: 364-368$, 1984.

12 Dale E., Gerlach D.H., Wilhite A.L.: Menstrual dysfunction in runners. Obstet Gynecoll 54:47-53,1979.

13 Dessypris A., Kuoppasalmi K., Adlercreutz H: Plasma cortisol, testosterone, androstenedione and luteinizing hormone in a non-competetive marathon run. J Steroid Blochem 7:33-37,1976.

14 Dufaux B., Hoederath A., Heck H., Hollmann W.: Serum lestosterone levels during the first hours and days after a prolonged physicall exercise and the influence of physicall training. Fourth Int Symp Blochem Exerc abstract 47, Brussels, 1979.

15 Dufaux B., Assmann G., Order U., Holderath A., Hollmann W.: Plasma lipoproteins, hormones, and energy substrates during the first days after prollonged exercise. Int $\mathbb{S}$ Sports Med 2: 256-260, 1981. 
16 Fellman $\mathbf{N}_{\text {., }}$ Coudert J., Jarrige J.F., Bedu $\mathbf{M}_{\text {., }}$ Denis $C$., Boucher D., Lacour J.R.: Effects of endurance training on the androgenic response to exercise in man. Int J Sports Med 6: 215-219,1985.

17 Few J.D.: Effect of exercise on the secretion and metabolism of cortisol in man. $J$ Endocr 62:341-353,1974.

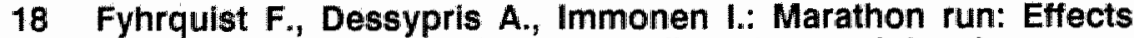
on plasma renin activity, renin sibstrate, angiotensin

converting enzyem, and cortisol. Horm Metab Res 15:96-99, 1983.

19 Galbo H.: Hormonal and metabolic adaptation to exercise. Thieme, Stuttgart, 1983.

20 Golldberg A.L.: Protein turnover in skeletal muscle. J Biol Chem 244: 3217-3222 and 3223-3227,1969.

21 Grigsby J.S., Bergen W.G., Merkel R.A.: The effect of testosterone on skeletal muscle development and protein synthesis in rabbits. Growth 40:303-310,1976.

22 Janssen G.M.E., Kuipers $H_{\text {, }}$, Keizer H.: Plasma CPK and AST activity, and plasma testosterone after $200 \mathrm{~km}$ speed skating. Med Scil Sport Exer 18 (suppl):205,1986.

23 Kelzer H.A., Poortman J., Bunnik G.S.J.: Influence of physical exercise on sex-hormone metabolism. J Appl Physiol: Respirat Environ Exerc Physiol 48:765-769,1980.

24 Keizer H.A., Van Soest O.P.M., Beckers E.: Exercise-induced androgen responses in trained and untrained women, in Dotson C.O., Humphrey J.H. (eds): Exercise physlology II. ams press, Inc., NEW YORK, 1986, pp 35-48.

25 Keizer H.A., Kuipers H., Haan de J., Beckers E., Habets L.: Multiple hormonal responses to exercise in trained and untrained women, in Kelzer H.A. (ed): Hormonal responses in women as a function of physical exercise and training. Int $J$ Sports Med 8(suppl 3):139-150,1987.

26 Keizer H.A., Kuipers H., Haan de J., Janssen G.M.E., Beckers E., Habets L., Kranenburg van G., Geurten P.: Hormonal responses to exercise in previousily untrained women. In Kelzer $H_{i} A_{\text {. }}$ (ed): Hormonal responses in women as a function of physical exercise and training. Int $J$ Sports Med 8 (suppl 3):154-160,1987.

27 Kelly F.J., McGrath J.A., Goldsplnk D.F., Cullen M.J.: A morphological/blochemical study on the actions of corticosteroids on rat skeletal muscle. Muscle Nerve 9:1-10,1986.

28 Krieg M.: Characterization of the androgen receptor in the skeletal muscle of the rat. Sterolds 28:261-265,1976.

29 Kuoppasalmi K., Nanerl H., Harkonen M., Adlercreutz $H$.: Plasma cortisol, androstenedione, testosterone and luteinizing hormone in running exercise of different intensities. J Clin Lab Invest 40:403-409,1980.

30 Kuoppasalmi K., Adlercreutz H.: Interaction between catabolic and anabolic steroid hormones in muscular exercise, in

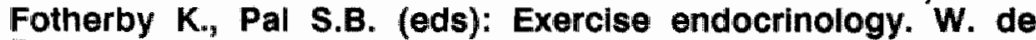
Gruyter, Berlin, 1985, pp 65-156.

31 Kurowski T.T., Chatterton R.T., Hickson R.C.: Countereffects of compensatory overload and glucocorticoids In skeletal muscle: androgen and glucoconticold cytosol receptor binding. J. Steroid Blochem. 21:137-145,1984. 
32 Kurowski T.T., Capaccio J.A., Hickson R.C.: Glucocorticolids override androgen-induced muscle growth. Med Scl Sports Exerc 18 (suppl): 109,1986.

33 Maron M.B., Horvath S.M., Wilkerson J.E.: Blood bilochemical alterations during recovery from competetive marathon running. Europ J Appl Physiol 36:231-238,1977.

34 Michel G., Baulieu E-M.: Androgen receptor in rat skeletal muscle: Chracterization and physiological variations. Endocrinol. 107:2088-2098,1980.

35 Morville R., Pesquines P.C., Guezennec C.Y., Serrurie B.D., Guignaro M.: Plasma variations in testticular and adrenal androgens during prolonged exercilse in man. Ann Endocrinol (Paris) 40: 501-510,1979.

36 Newark S.R., Hìmathongkam T., Martin R.P., Cooper K.H., Rose L.I.: Adrenocortical response to marathon running. $\mathrm{J} \mathrm{Clin}$ Endocrinol Metab 42:393-394,1976.

37 Remes K., Kuoppasalmi K., Adlercreutz H.: Effect of Long-term physical training on plasma testosterone, androstenedione, luteinizing hormone and sex-hormone binding capacity. Scan $J$ Clin Lab Invest 39:743-749,1979.

38 Rivier C.,Vale W.: Diminished responsiveness of the hypothalamic-pituitary-adrenal axis of the rat during exposure to prolonged stress: a pituitary-mediated mechanism. Endocrinol 121:1320-1328,1987.

39 Ronkainen H.R.A;, Pakarinen A.J., Kauppila A.J.I.: Adrenocortical function of female endurance runners and joggers. Med Sci Sports Exerc 18:385-389,1986.

40 Sapolsky R.M., Krey L.C., McEwen B.S... The neuroendocrinology of stress and aging: The glucocorticold cascade hypothesis. Endocrinol Rev 7:284-301,1986.

41 Selye H.: The general adaptation syndrome and the diseases of adaptation. J Clin Endocrinol Metab 6:117-230,1946.

42 Sundsfjord J.A., Stromme S.B., Aakvaag A.: Plasma aldosterone (PRA), plasma renin activity (PRA) and cortisol (PF) during exercise, in Howald H., Poortmans J.A. (eds): Metabolic adaptation to prolonged physical exercise. Birkhauser Verlag, Basel , Switserland, 1975, pp 308-314.

43 Sutton J.A., Young J.D., Lazarus L., Hickle J.B., Maksytis J.: The hormonal responses to physical exercise. Austr Ann Med 18:84-90,1969.

44 Viru A.: Hormones in muscular activity. CRC Press Inc., Boca Raton, Florida, U.S.A., 1985. 
Chapter 5 Biochemistry and morphology of skeletal muscle

5.1 The effect of training and 15, 25 and $42 \mathrm{~km}$ contests on the skeletal muscle content of adenine and guanine nucleotides, creatine phosphate and glycogen

\section{Introduction}

Long-distance running requires a well-balanced metabolic performance of the skeletal muscies used. Muscle metabolic activity and coordlination of the various metabolic pathways can be improved by training. In the present study initially untrained volunteers were subjected to a training programme enabling them to complete a 15 , 25 and $42 \mathrm{~km}$ contest following $6,11-112$ and 18-20 months after the onset of the training programme, respectively.

In the present paper two goals were aimed at. Firstly, to dellineate the effect of training on the content of a variety of biochemical substances such as adenine and guanine nucleotides and related

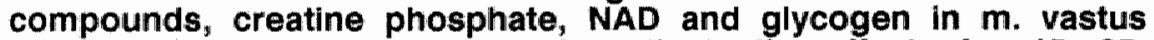
lateralis. Secondly, in order to investigate the effect of a 15, 25 and $42 \mathrm{~km}$ contest performed during the training period on the skeletal muscle energy metabolism, the muscle content of the above mentioned biochemical substances was monitored at varlous time Intervals after completion of the expenditure.

\section{Materials and methods}

\section{Subjects}

The 36 subjects (25 males and 11 females) of the treadmill group (TG) volunteered to participate in this study. They were informed of the purpose, methods and possible complications of the experimental procedures. Blopsy samples of 2 males were not taken before and after the $15 \mathrm{~km}$ contest. Not all samples of the biopsy samples before and after 25 and $42 \mathrm{~km}$ contests were used for the determinations of the variables due to various technical problems. The age of the subjects on 1-1-1986 ranged from 22 to 47 years (Table 2.3; p. 27).

Muscle sampling

Tissue specimens were taken from the $\mathrm{m}$. vastus lateralis alternately the left leg and the right one, with the use of a Bergström needlle according to Evans (2). The first set of bilopsles was taken about 5 days prior to the contest (Chapter 2; p. 30-32). 
The second set of bilopsies was taken $268 \pm 50,254 \pm 70$ and $254 \pm 139 \mathrm{~min}$ after the end of the $15,2542 \mathrm{~km}$ contest, respectively and a third set of biopsies was obtained $8-9$ days after the contests (Fig. 5.1.1).

FIELOTEST GHOUP

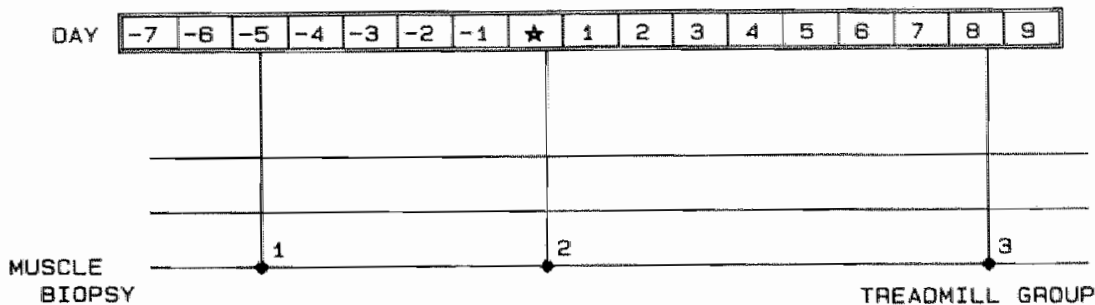

Fig. 5.1.1 Time schedule of the protocol before and after the 3 contests with speclal reference to time Intervals for blopsles.

On the line of muscle blopsy 1,2 and 3 before and after the $15 \mathrm{~km}$ represent $B_{1}, B_{2}$ and $B_{3}$, before and after the $25 \mathrm{~km} B_{4}, B_{5}$ and $B_{6}$ and before and after the $42 \mathrm{~km}$ contest $\mathrm{B}_{7}, \mathrm{~B}_{8}$ and $\mathrm{Bg}_{9}$, respectively.

\section{Results}

The first aim of this study was to delineate the effect, if any, of training of initially untrained volunteers, on the muscle content of adenine nucleotides and related substances, creatine phosphate, inorganic phosphate, glycogen, and lactate.

Table 5.1.1 presents the values of ATP, ADP and AMP, and the energy charge as measured in the biopsies $B_{1}, B_{4}$ and $B_{7}$. Blopsy $B_{1}$ was taken 6 months after the start of the training. The average time between $B_{1}$ and $B_{4}$, and between $B_{4}$ and $B_{7}$, amounted to 5-6 and 6-8 months, respectively.

The content of ATP and the sum of ATP, ADP and AMP significantly increased during the last 11 to 12 months training period in the total group and the male subgroup. Values in the female subgroup tended to increase but the differences did not reach the level of significance, most likely due to the relatively small number of subjects in the female subgroup. ADP and AMP values remained constant throughout the whole experimental period.

Figure 5.1.2 represents histograms, showing the values of ATP, creatine phosphate and glycogen as measured in biopsies $B_{1}$ before the 15 $\mathrm{km}$ contest (left of the axis) and $B_{7}$ before the 42 contest (right of the axis). These histograms clearly indicate a substantial intra-individual variation in sikeletal muscle content of the sub- stances measured. The shift to higher ATP values is clearly present during the training period. This shift was statistically significant (Table 5.1.1). 
Table 5.1.1 Content of adenine nucleotides (ATP, ADP and AMP), and energy charge in blopsles from $m$. vastus lateralls. Effect of training

aden lne nuc leot ldes

\begin{tabular}{|c|c|c|c|c|c|c|c|}
\hline \multirow{2}{*}{\multicolumn{3}{|c|}{ blapsy group $n$}} & & & & & \multirow[b]{2}{*}{ E.C. } \\
\hline & & & ATP & ADP & AMP & sum & \\
\hline \multirow[t]{3}{*}{$\mathrm{B}_{1}$} & & 34 & \pm 3.4 & .7 & $0.2 \pm 0.1$ & $25.3 \pm 3.9$ & $0.93 \pm 0.02$ \\
\hline & & 23 & 3 & 2 & 1 & 7 & .01 \\
\hline & female & 11 & 3.3 & 2.8 & 0.1 & 23 &.$\infty$ \\
\hline \multirow[t]{3}{*}{$\mathrm{B}_{4}$} & & 17 & .8 & & & & 0. \\
\hline & & 11 & 7.3 & 2. & .2 & 23 & .00 \\
\hline & female & 6 & $25.1 \pm 5.1$ & $3.5 \pm 1.3$ & $0.3 \pm 0.4$ & $28.9 \pm 4.7$ & $0.88 \pm 0.04$ \\
\hline \multirow[t]{3}{*}{$\mathrm{B}_{7}$} & otal & 27 & $24.8 \pm 4.1+$ & $2.8 \pm 0.8$ & $0.2 \pm 0.1$ & $27.6 \pm 4.7 *$ & $0.92 \pm 0.04$ \\
\hline & & 18 & $25.8 \pm 4.2$ & $2.9 \pm 0.9$ & $0.2 \pm 0.1$ & $28.9 \pm 4.9$ & $0.92 \pm 0.04$ \\
\hline & fenale & $\nabla$ & $22.7 \pm 2.9$ & $2.5 \pm 0.6$ & $0.1 \pm 0.1$ & $25.1 \pm 3.1$ & $0.92 \pm 0.04$ \\
\hline
\end{tabular}

Mean values \pm sd of ATP, ADP and AMP are given in Imol. $g^{-1}$ dry welght. $B_{1}, B_{4}$ and $B_{7}$ refer to blopsles obtalned at about $6_{1}, 12$ and 19 months after the onset of the tralning, respect Ively; $n$ refers to number of blopsles studled.

Energy charge (E.C.) is $([A T P]+/ 2[A D P]) \cdot([A T P]+[A D P]+[A M P])^{-1}$; sum refers to sum of ATP, ADP and AMP. \# Indlcates signiflcantly different from corresponding values in blopsy $B_{1}$.

Table 5.1.2 Content of creatlne phosphate, Inorganic phosphate, glyoogen and lactate in blopsles from $m$. vastus lateralis. Effect of training

\begin{tabular}{|c|c|c|c|c|c|}
\hline \multicolumn{2}{|c|}{ blopsy group } & \multirow{2}{*}{$\begin{array}{l}C P \\
67.7 \pm 15.3\end{array}$} & \multirow{2}{*}{$\frac{P \|}{m}$} & \multirow{2}{*}{$\frac{\text { glycogen }}{248 \pm 43}$} & \multirow{2}{*}{$\begin{array}{l}\text { lactate } \\
18.1 \pm 9.4\end{array}$} \\
\hline$\overline{\mathrm{B}_{1}}$ & total & & & & \\
\hline & malle & $67.8 \pm 16.0$ & $m$ & $253 \pm 46$ & $20.2 \pm 10.4$ \\
\hline & fena le & $67.7 \pm 14.3$ & $\mathrm{~mm}$ & $236 \pm 31$ & $13.6 \pm 4.4$ \\
\hline \multirow[t]{3}{*}{$B_{4}$} & total & $88.1 \pm 29.5$ & $\mathrm{~m}$ & $324 \pm 49 *$ & $20.9 \pm 12.0$ \\
\hline & male & $90.3 \pm 31.4$ & $m$ & $314 \pm 38 *$ & $23.4 \pm 11.7$ \\
\hline & ferrale & $83.9 \pm 27.8$ & $m$ & $348 \pm 67$ & $16.3 \pm 12.1$ \\
\hline \multirow[t]{3}{*}{$\mathrm{B}_{7}$} & total & $85.7 \pm 16.7$ 㖿 & $41.7 \pm 14.7$ & $291 \pm 50 \#$ & $15.7 \pm 8.3$ \\
\hline & male & $87.5 \pm 16.9$ & $43.0 \pm 16.8$ & $291 \pm 47$ * & $16.7 \pm 6.9$ \\
\hline & fem & $82.1 \pm 16.6$ & $39.3 \pm 9.9$ & $292 \pm 59$ \# & $13.6 \pm 10.8$ \\
\hline
\end{tabular}

Mean values \pm sd of creat ine phosphate (CP), Inorganlc phosphate (PI). glycogen (glucose moletles) and lactate are given in $\mid$ mol. $\mathrm{g}^{-1}$ dry welght; $\mathrm{mm}$ indlcates not measured. See for number of subjects and further explanatlons legend of Table 5.1.1. 

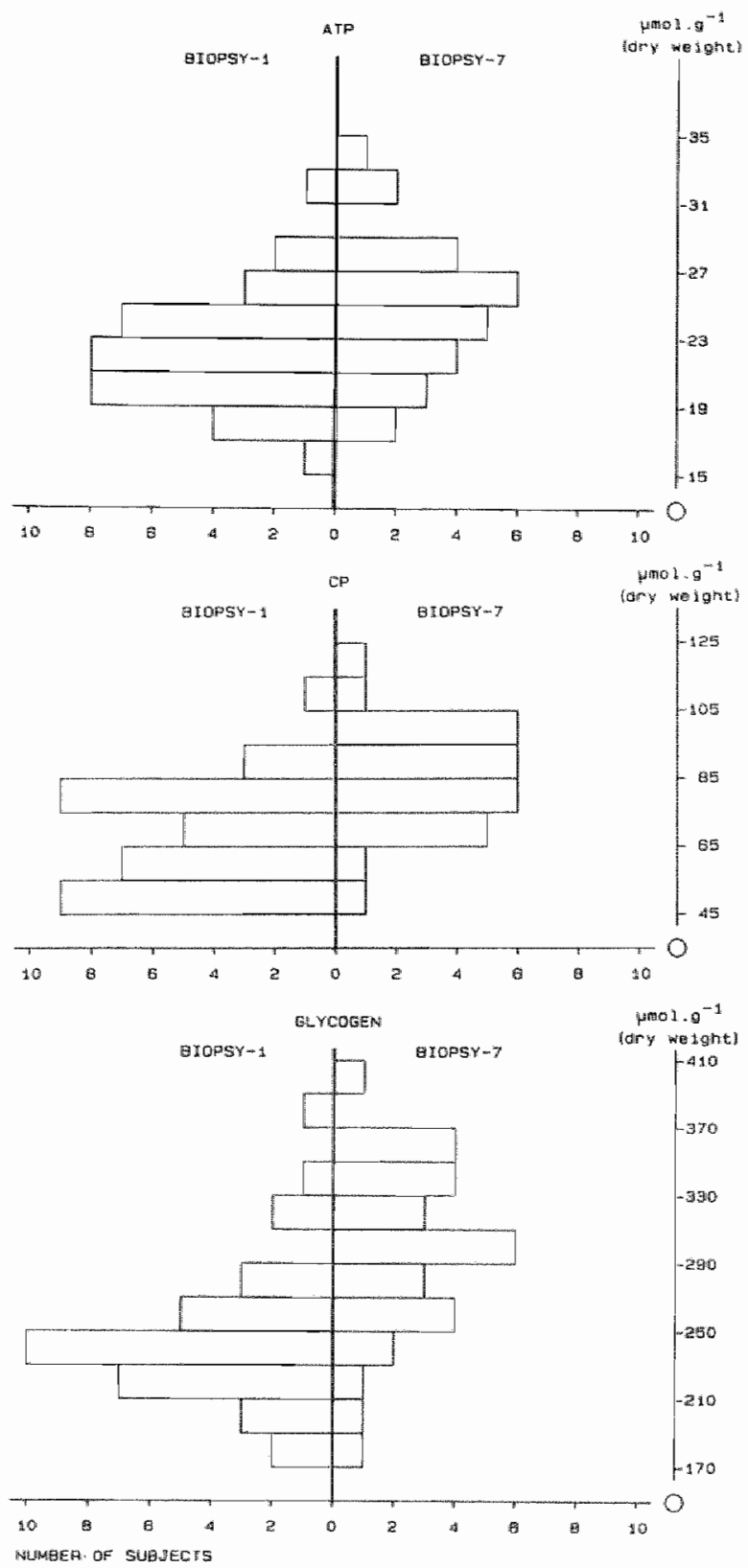

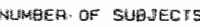

FIg. 5.1.2 HIstograns of ATP, creatlme phosphate (CP) and glycogen in tissue specimen obtalned in 27-34 subjects during the pre-contest perlod of the $15 \mathrm{~km}$ contest (blopsles $B_{1}$ ) and the 42 $\mathrm{km}$ contest (blopsies $B_{7}$ ), respectively. The shift to hlgher tisisue levels was found to be signiflcant for ATP, CP and glycogen. 

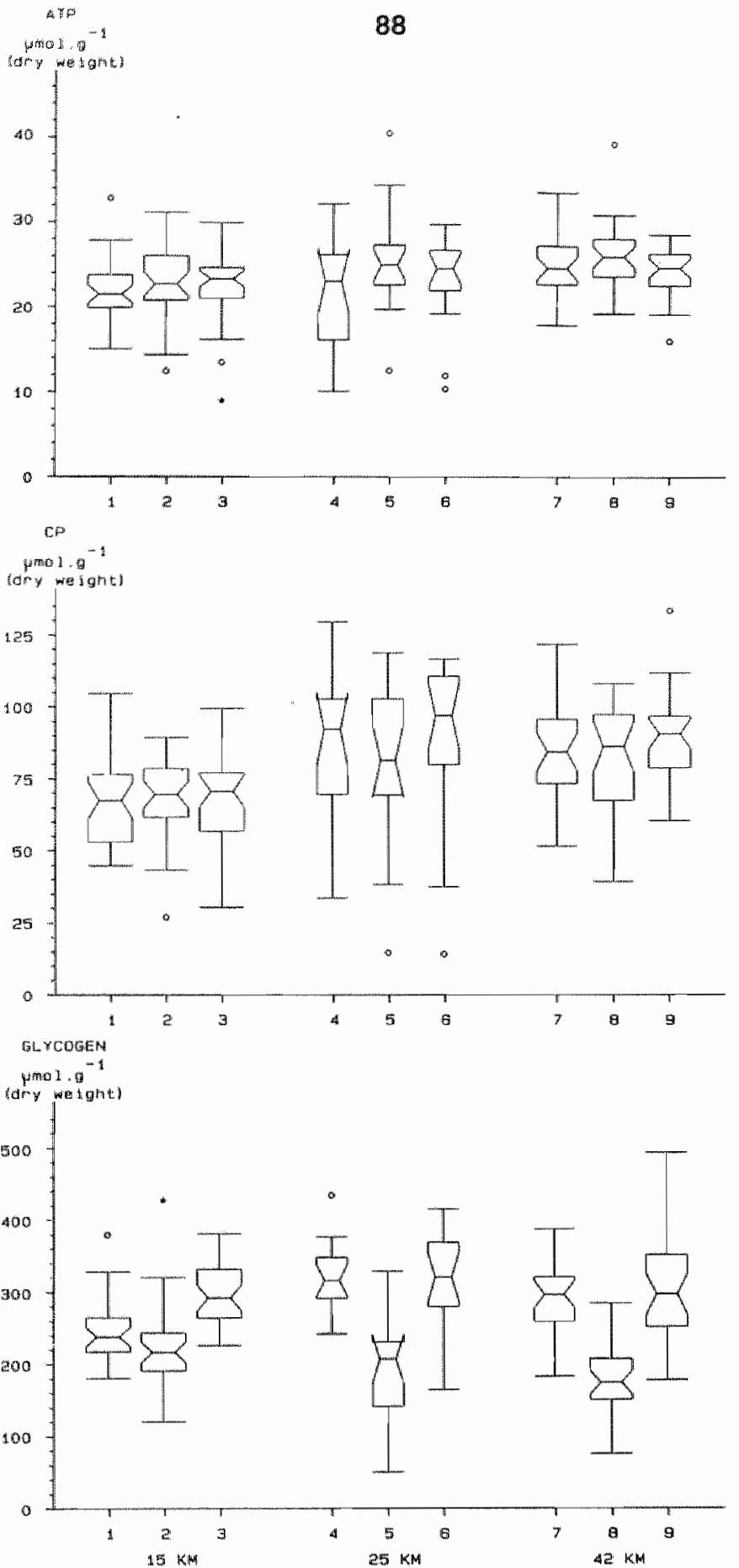

FIg. 5.1.3 Survey of the time course of the concentrations of ATP, $\mathrm{CP}$ and glycogen in box-and-wh/sker plots dur Ing the whole study. 
Table 5.1.2 indicates that creatine phosphate levels increased significantly during the course of the training. For the whole group the values in biopsy $B_{A}$ were significantly higher than those of biopsy $B_{1}$ and remained at this increased level thereafter. A similar pattern was observed for glycogen.

The histograms presented in Fig. 5.1.2 show the considerable intraindividual variation, on the one hand and the shift to higher creatine phosphate and glycogen levels in the tissue samples of volunteers submitted to the training programme, on the other. In Fig. 5.1.3 changes of the concentrations of ATP, CP and glycogen are shown in box-and-whisker plots during the whole period.

In general, resting tissue lactate levels did not change throughout the whole training period. However, some of the individual purine base and oxypurine levels changed in the time course of the training (Table 5.1.2 and 5.1.3).

Table 5.1 .3 content of pur Ine bases and oxypurines in blopsies from $m$. vastus lateralls. Effect of tralning

\begin{tabular}{|c|c|c|c|c|c|c|}
\hline$\overline{\mathrm{blo}}$ & group & Adenos Ine & Inos Ine & $\begin{array}{l}\text { Hypo- } \\
\text { xanthine }\end{array}$ & Xanthine & Sum \\
\hline$\overline{B_{1}}$ & $\begin{array}{r}\text { total } \\
\text { male } \\
\text { female }\end{array}$ & $\begin{array}{l}0.02 \pm 0.05 \\
0.02 \pm 0.04 \\
0.03 \pm 0.07\end{array}$ & $\begin{array}{l}0.04 \pm 0.10 \\
0.05 \pm 0.12 \\
0.02 \pm 0.06\end{array}$ & $\begin{array}{l}0.02 \pm 0.04 \\
0.02 \pm 0.04 \\
0.03 \pm 0.05\end{array}$ & $\begin{array}{l}\text { ind } \\
\text { ind } \\
\text { ind }\end{array}$ & $\begin{array}{l}0.08 \pm 0.12 \\
0.08 \pm 0.13 \\
0.07 \pm 0.10\end{array}$ \\
\hline $\mathbb{B}_{4}$ & $\begin{array}{l}\text { total } \\
\text { male } \\
\text { female }\end{array}$ & $\begin{array}{l}0.08 \pm 0.08 \\
0.09 \pm 0.09 \# \\
0.05 \pm 0.05\end{array}$ & $\begin{array}{l}0.04 \pm 0.10 \\
0.05 \pm 0.12 \\
0.02 \pm 0.04\end{array}$ & $\begin{array}{l}0.07 \pm 0.15 \\
0.07 \pm 0.15 \\
0.05 \pm 0.08\end{array}$ & $\begin{array}{l}\text { nd } \\
\text { nd } \\
\text { nd }\end{array}$ & $\begin{array}{l}0.18 \pm 0.23 \\
0.21 \pm 0.27 \\
0.12 \pm 0.16\end{array}$ \\
\hline 7 & $\begin{array}{r}\text { total } \\
\text { male } \\
\text { female }\end{array}$ & $\begin{array}{l}0.11 \pm 0.18 \\
0.08 \pm 0.12 \\
0.17 \pm 0.26\end{array}$ & $\begin{array}{l}0.16 \pm 0.30 \\
0.18 \pm 0.30 \\
0.11 \pm 0.23\end{array}$ & $\begin{array}{c}0.01 \pm 0.04 \\
0.01 \pm 0.05 \\
\text { nd }\end{array}$ & $\begin{array}{l}\text { nd } \\
\text { nd } \\
\text { nd }\end{array}$ & $\begin{array}{l}0.27 \pm 0.40 \\
0.27 \pm 0.34 \\
0.28 \pm 0.47\end{array}$ \\
\hline
\end{tabular}

Mean values \pm sd are glven in $\mid \mathrm{mol}^{-1}$ dry welght; nd Indlcates lower than $0.01 \mathrm{~mol} \cdot \mathrm{g}^{-1}$ dry welght. See legend of Table 5.1.1 for further explanatlon.

Table 5.1.4 Content of GTP, GDP, IMP and NAD+ In blopsles from m. vastus llateralis. Effect of trallining

\begin{tabular}{|c|c|c|c|c|c|}
\hline blopsy & giroup & $\overline{\text { GTP }}$ & GDP & IMP & NAD $^{+}$ \\
\hline$B_{1}$ & $\begin{array}{r}\text { total } \\
\text { malle } \\
\text { female }\end{array}$ & $\begin{array}{l}0.62 \pm 0.10 \\
0.62 \pm 0.10 \\
0.60 \pm 0.09\end{array}$ & $\begin{array}{l}0.11 \pm 0.09 \\
0.11 \pm 0.07 \\
0.10 \pm 0.12\end{array}$ & $\begin{array}{l}0.15 \pm 0.22 \\
0.15 \pm 0.24 \\
0.12 \pm 0.18\end{array}$ & $\begin{array}{l}1.5 \pm 0.3 \\
1.6 \pm 0.3 \\
1.4 \pm 0.2\end{array}$ \\
\hline $\mathrm{B}_{4}$ & $\begin{array}{r}\text { total } \\
\text { male } \\
\text { female }\end{array}$ & $\begin{array}{l}0.77 \pm 0.34 \\
0.76 \pm 0.41 \\
0.77 \pm 0.22\end{array}$ & $\begin{array}{l}0.15 \pm 0.13 \\
0.12 \pm 0.09 \\
0.22 \pm 0.18\end{array}$ & $\begin{array}{l}0.32 \pm 0.42 \\
0.36 \pm 0.52 \\
0.27 \pm 0.16\end{array}$ & $\begin{array}{l}2.1 \pm 1.1 * \\
1.9 \pm 1.0 \\
2.3 \pm 1.4 \%\end{array}$ \\
\hline$B_{7}$ & $\begin{array}{r}\text { total } \\
\text { male } \\
\text { female }\end{array}$ & $\begin{array}{l}0.81 \pm 0.23 * \\
0.82 \pm 0.25 * \\
0.79 \pm 0.20 *\end{array}$ & $\begin{array}{l}0.16 \pm 0.09 * \\
0.15 \pm 0.07 \\
0.19 \pm 0.12 *\end{array}$ & $\begin{array}{l}0.36 \pm 0.48 \\
0.37 \pm 0.43 * \\
0.36 \pm 0.60\end{array}$ & $\begin{array}{l}1.7 \pm 0.4 * \\
1.8 \pm 0.5 * \\
1.5 \pm 0.2\end{array}$ \\
\hline
\end{tabular}

Mean values \pm sd are given in $\mu \mathrm{mol} \cdot \mathrm{g}^{-1}$ dry wellght. See legend of Table 5.1.1 for further explanation. 
The sum of adenosine, inosine, hypoxanthine and xanthine was found to have increased in the total group and the male subgroup in biopsy $B_{7}$ as compared to $B_{1}$, obtained about 11 to 14 months earlier. As shown in Table 5.1.4 tissue levels of both GTP and GDP did signiticantly increase at the end of the training period. Similar results were obtained for IMP. The increased values of IMP in the female subgroup did not reach the level of significance, most likely due to the small number of subjects. NAD - started already to increase in biopsy $B_{4}$.

The second objective of the study was to monitor changes in tissue contents of the biochemical substances, essential for adequate skeletal muscle function, caused by running contests over a length of 15,25 and $42 \mathrm{~km}$ (marathon).

In general no major effect of the 15 and $25 \mathrm{~km}$ contest on the tissue content of ATP, ADP, AMP, IMP, creatine phosphate, NAD + and lactate could be observed (Table 5.1.5 and 5.1.6).

Table 5.1 .5 content of ATP, ADP, AMP, IMP and pur Ines in $\mathrm{m}$. vastus lateralls. Effect of contest.

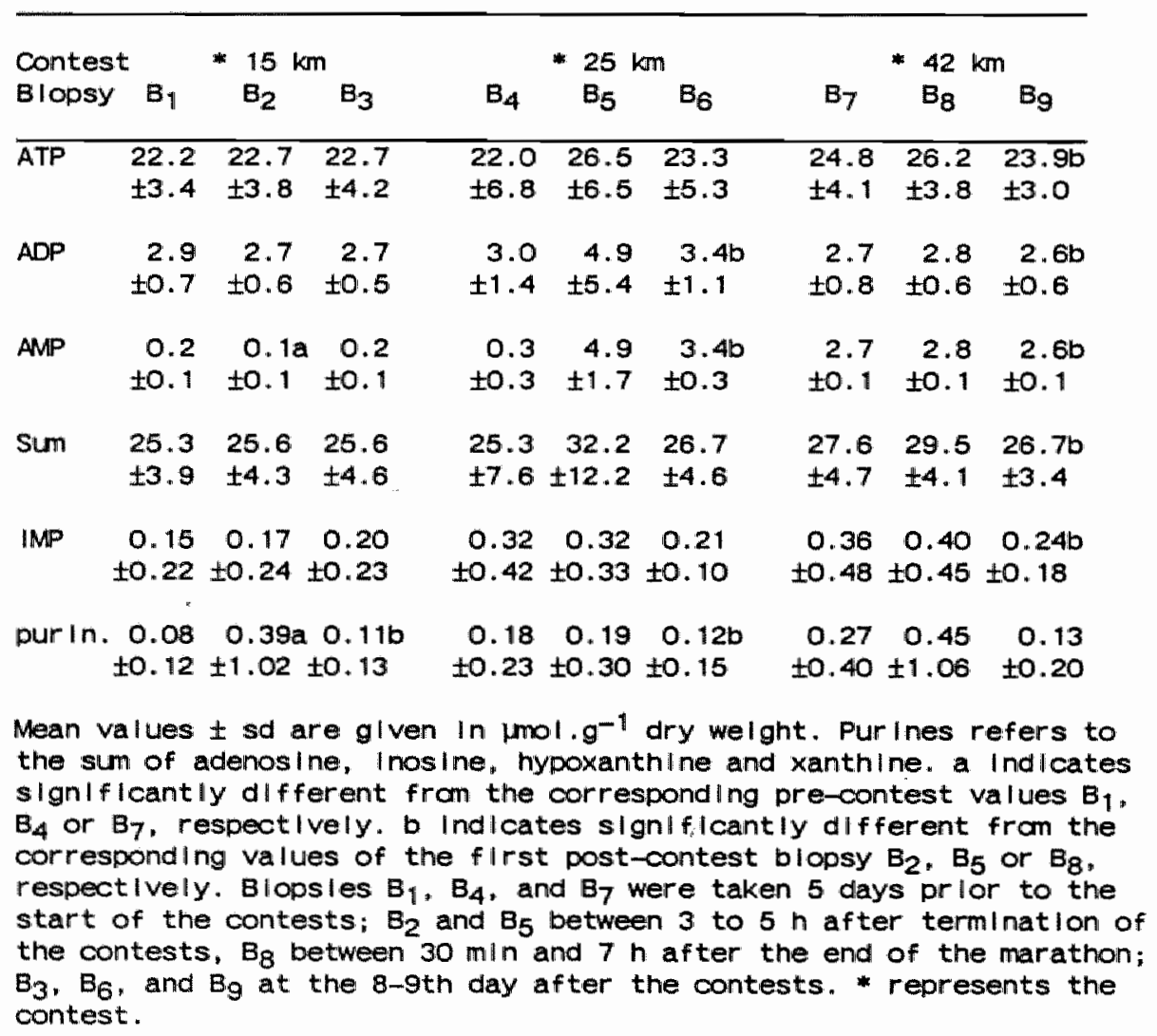


The tissue content of (oxy)purines (the sum of adenosine, inosine, hypoxanthine and xanthine) was increased significantly in the first post-15 $\mathrm{km}$ contest biopsy and returned to pre-contest levels thereafter. Although comparable patterns were observed after the 25 and $42 \mathrm{~km}$ contests, in most cases the changes did not reach the level of significance.

The present findings indicate that the content of ATP; ADP, IMP and NAD + declined after the $42 \mathrm{~km}$ contest when biopsy $B_{\text {e }}$ was compared to $\mathrm{B}_{\mathrm{a}}$ (Table 5.1.5). It should be noted that both the early and late post-contest values (biopsy $\mathbf{B}_{\mathbf{a}}$ and $\mathbf{B}_{\mathbf{o}}$ ) did not significantly differ from the corresponding pre-contest values. The level of inorganic phosphate had significantly increased in the first biopsy after the 25 and $42 \mathrm{~km}$ contest and returned to their respective pre-contest vallues thereafter (Table 5.1.6).

Lactate showed a comparable pattern, albeit that only the changes observed during the $42 \mathrm{~km}$ contest period reached the level of significance. The changes in the content of glycogen were very substantial. The level in glycogen in the first biopsy taken after the 15,25 and $42 \mathrm{~km}$ contest was found to be 91,60 and $62 \%$, respectively, of the corresponding pre-contest values $(p<0.05)$. Nine days after the contest glycogen levels had returned to supra-normal values after the $15 \mathrm{~km}$ contest and to pre-contest values after the 25 and $42 \mathrm{~km}$ contest.

Table 5.1.6 content of creatline phosphate (CP), Inorganlc phosphate (PI), glycogen, lactate and $\mathrm{NAD}^{+}$In m. vastus lateral Is. Effect of contest

\begin{tabular}{|c|c|c|c|c|c|c|c|c|c|}
\hline Contest & $x^{2}$ & $15 \mathrm{k}$ & $\bar{m}$ & " & $25 \mathrm{k}$ & & " & $42 k$ & \\
\hline Blopsy & $\mathrm{B}_{1}$ & $\mathrm{~B}_{2}$ & $\mathrm{~B}_{3}$ & $\mathrm{~B}_{4}$ & $\mathrm{~B}_{5}$ & $\mathrm{~B}_{6}$ & $B_{7}$ & $\mathrm{~B}_{8}$ & $\mathrm{Bg}_{9}$ \\
\hline$\overline{\mathrm{CP}}$ & $\begin{array}{l}67 \\
\pm 15\end{array}$ & $\begin{array}{l}69 \\
\pm 14\end{array}$ & $\begin{array}{l}69 \\
\pm 15\end{array}$ & $\begin{array}{l}88 \\
\pm 29\end{array}$ & $\begin{array}{l}77 \\
\pm 32\end{array}$ & $\begin{array}{l}87 \\
\pm 29\end{array}$ & $\begin{array}{l}85 \\
\pm 16\end{array}$ & $\begin{array}{l}83 \\
\pm 19\end{array}$ & $\begin{array}{l}90 \\
\pm 16\end{array}$ \\
\hline PI & $\mathrm{mm}$ & $\mathrm{mm}$ & $\mathrm{rm}$ & $\mathrm{mm}$ & $\mathrm{mm}$ & $\mathrm{rm}$ & $\begin{array}{r}41 \\
\pm 14\end{array}$ & $\begin{array}{l}46 a \\
\pm 9\end{array}$ & $\begin{array}{l}37 \mathrm{~b} \\
\pm 6\end{array}$ \\
\hline $\begin{array}{l}\text { Giyco- } \\
\text { gen }\end{array}$ & $\begin{array}{l}248 \\
\pm 33\end{array}$ & $\begin{array}{l}225 \\
\pm 55\end{array}$ & $\begin{array}{l}299 a, b \\
\pm 42\end{array}$ & $\begin{array}{l}324 \\
\pm 49\end{array}$ & $\begin{array}{l}195 a \\
\pm 70\end{array}$ & $\begin{array}{l}323 b \\
\pm 65\end{array}$ & $\begin{array}{l}291 \\
\pm 47\end{array}$ & $\begin{array}{l}179 a \\
\pm 52\end{array}$ & $\begin{array}{l}310 \mathrm{~b} \\
\pm 74\end{array}$ \\
\hline Lactate & $\begin{array}{l}18 \\
\pm 9\end{array}$ & $\begin{array}{r}21 \\
\pm 115\end{array}$ & $\begin{array}{l}19 \\
\pm 8\end{array}$ & $\begin{array}{r}21 \\
\pm 12\end{array}$ & $\begin{array}{r}25 \\
\pm 15\end{array}$ & $\begin{array}{l}18 \\
\pm 8\end{array}$ & $\begin{array}{l}16 \\
\pm 8\end{array}$ & $\begin{array}{r}27 a \\
\pm 19\end{array}$ & $\begin{array}{l}16 \mathrm{~b} \\
\pm 9\end{array}$ \\
\hline $\mathrm{NAD}^{+}$ & $\begin{array}{r}1.5 \\
\pm 0.3\end{array}$ & $\begin{array}{r}1.5 \\
\pm 0.4\end{array}$ & $\begin{array}{r}1.6 \\
\pm 0.4\end{array}$ & $\begin{array}{r}2.1 \\
\pm 1.1\end{array}$ & $\begin{array}{r}2.6 \\
\pm 2.3\end{array}$ & $\begin{array}{r}1.9 \\
\pm 0.7\end{array}$ & $\begin{array}{r}1.7 \\
\pm 0.4\end{array}$ & $\begin{aligned} & 1.9 a \\
& \pm 0.4\end{aligned}$ & $\begin{array}{l}1.7 \mathrm{~b} \\
\pm 0.4\end{array}$ \\
\hline
\end{tabular}

Values are glven in $\mu$ mol. $g^{-1}$ dry welght (mean tsd). Glycogen is expressed as glucose moletles. CP: creat ine phosphate;

$P \mid$ : Inorganll phosphate. See legend to Table 5.1 .5 for further explanation. * represents the contest; $\mathrm{mm}$ Indlcates not measured. 
No consistent gender differences could be observed in the described changes, if any, in metabollic parameters following the contests. For some parameters onlly the male group followed the total group with respect to significant differences. This is most likely due to the fact that the number of female subjects in this part of the study was rather small, which prevented some changes to reach the level of signilicance.

\section{Discussion}

The present study provides information on the effect of training of recreational runners on the content of high-energy phosphates and related substances, and glycogen in $\mathrm{m}$. vastus lateralis. In addition, the effect of a 15, 25 and $42 \mathrm{~km}$ contest on these substances has been monitored.

Effect of training

The tissue levels of high-energy phosphates such as ATP, creatine phosphate and GTP increased significantly during the training period. The levels in biopsies obtained in women tended to increase. This observation indicates a blochemical adaptation of the skeletal muscle as a consequence of the training protocol applied. This notion is supported by the findings that related substances such as GDP, IMP, NAD +, purine bases and oxypurlnes increased as well. The physiological significance of this increase remains open to speculation. Graham and co-workers reported a linear relationship between resting muscle levels of NAD + and percentage of sllow twitch fibers in human $m$. vastus lateralis (4). Since in the present study the rise in tissue content of NAD + parallels that of highenergy phosphates and related substances, the metabollic adaptation might be confined to the group of slow twitch fibers. From our biochemical data we cannot discriminate between an increase of the percentage of slow twitch fibers at the expense of other fiber types commonly present in $\mathrm{m}$. vastus lateralis and a selective increase of the blochemical substances per slow twitch fiber. In the latter case, one might speculate about the effect of increased high-energy phosphate levels per unit slow twitch fiber mass. Intracellular compartments llike mitrochondria, containing a substantlal part of these substances might be enlarged, enhancing the potential energy output in the form of high energy phosphates. Earlier studies of Golinick and co-workers have indlicated that the effect of training on leg skeletall muscle flbers is complex (3). The proportion of fast and slow twitch fibers did not change. The oxidative metabolic capacity, however, increased in both fiber types, whereas the glycolytic capacity appeared to have increased only in the fast twitch tibers.

In addition to nucleotides and related substances, the resting tissue content of glycogen increased during training. As has been pointed out by MacDougall and co-workers (9) the fact that the content of gijcogen in $\mathrm{m}$. vastus lateralis increases suggests that the present type of training places substantial clemands on glycolytic energy supply in addition to other non-carbohydrate linked energy providing systems. 
This notion might have important implications for the muscle performance of pursuing endurance exercise. It is generally accepted that fatty acid oxidation is quantitively the major high-energy phosphate regenerating system in such conditions. Newsholme (12) has emphasized that a metabolic limit is present in the rate of fatty acid oxidation so that sustained exercise at high power output requires the consumption of lipids and carbohydrates simultaneously. Therefore, the higher glycogen levels due to training are most likely advantageous for the energy producing catabolic process during long-distance running. It should be noted that only the acid-insoluble part of tissue glycogen has been monitored in the present study since we decided to combine the nucleotide assay with that of glycogen in the same tissue sample. According to the study of Jansson (6) the present glycogen levels will be underestimated by about $25 \%$. Therefore the changes described should be considered as semi-quantitative.

The increase in tissue levels of ATP is in line with observations made by Karlsson et al. (8), MacDougall et al. (9), and Eriksson and co-investigators (1). Conflicting results have been published regarding the effect on creatine phosphate levels. MacDougall and coworkers (9) found a small (about $3 \%$ ), but significant increase in $\mathrm{m}$. triceps brachil caused by heavy resistance training. In contrast, Karlsson and colleagues (8) could not observe any effect of physical training on the content of this high-energy phosphate in $\mathrm{m}$. quadriceps. Our observations corroborate the findings of the former investigators.

It should be kept in mind that the first resting biopsles (as denoted by $B_{1}$ ) were obtained 6 months after the onset of training. No biopsles were taken from the subjects prlor to the whole training procedure. Therefore the changes observed pertain only to the last part of the training programme. The total increase in the content of high-energy phosphates and glycogen of muscles from totally untrained to prepared for a marathon run might even be greater than the values presented in the Tables 5.1.1 through 5.1.4.

\section{Effect of long-distance running contest}

In general, no substantial effect of running over a distance of 15, 25 and $42 \mathrm{~km}$ on skeletal muscle adenine nucleotide levels could be observed, indicating that these expenditures are most llkely well tolerated from a bio-energetic point of view. If the supply of chemical energy does not match the demand a steady decline in tissue ATP levels can be anticipated $(11,15)$. As a consequence IMP will accumulate in the exercising tissue (10) with a concomitant degradation to purine bases and oxypurines (14). The latter substances will be released from the tissue into the bloodstream, causing a loss of purine material required for resynthesis of ATP in the post-exercise perlod. Despite unchanged nucleotide levels, evidence was obtained that skeletal muscle energy metabolism was affected to a certain extent by the prolonged contests. Firstly, there was a tendency of purines (degradation products of nucleotides) to increase as monitored in the tissue samples obtained after the contest. This increase was significant at the $15 \mathrm{~km}$ contest. 
Secondly, creatine phosphate levels tended to decrease during the 25 and $42 \mathrm{~km}$ contest with a significant concomitant increase in the tissue content of inorganic phosphate. It should be kept in mind that the first set of biopsies taken after the contests (denoted by $B_{2}, B_{s}$ and $B_{a}$, respectively) were obtained between $30 \mathrm{~min}$ to $7 \mathrm{~h}$ after termination of the contest. The time delay was mainly due to technical reasons. The subjects had to be transported from the site of the contest to the laboratory where they were biopsied. Therefore, resynthesis of nucleotides during this period cannot be excluded (11).

Highly interesting is that ATP and ADP, and also the sum of the adenine nucleotides, decreased significantly in the period of 9 days following the marathon, when compared with tissue levels monitored in the biopsies obtained within $7 \mathrm{~h}$ atter termination of the marathon. The reason for this decrease has not been elucidated. Probably it is related to the muscular post-marathon distress often observed in long distance runners (5).

It is a well-known phenomenon that the glycogen content of muscles decreases during heavy endurance exercise $(12,13)$. In the present study we found a decrease of the glycogen content in $m$. vastus lateralis to 90,60 and $62 \%$ of the pre-contest content after the 15, 25 and 42 contest, respectively. A continuous supply of endogenous glucose moleties is a prerequisite for sufficient energy production during heavy, sustained endurance activity (12). In this light the more depleted glycogen stores after the $25 \mathrm{~km}$ than after the $15 \mathrm{~km}$ contest can be understood. Interestingly, no significant difference was found in the decrease at the $25 \mathrm{~km}$ contest and the marathon. Various explanations are at hand. Firstly, there may an effect of training. The $42 \mathrm{~km}$ contest was performed about 6 to 8 months after the $25 \mathrm{~km}$ contest. In the meantime the training had been continued. Jansson and Kayser (7) have recently reported that the contribution of fat oxidation to overall energy production in skeletal muscle during exercise is greater in trained than untrained subjects. Their findings might explain our observation that during a $42 \mathrm{~km}$ contest muscle glycogen levels are not more severelly depleted than during a $25 \mathrm{~km}$ contest. Secondly, it cannot be ruled out that our results are marred by the fact that the second set of biopsies are taken from $30 \mathrm{~min}$ to $6 \mathrm{~h}$ after the contest. As a consequence, the values are not representative for the tissue content of glycogen Immediately after termination of the contest. Post-contest glycogen resynthesis might already have occurred (13). From our own study we have obtained indirect Information that glycogen resynthesis started within the first hours after the end of the marathon contest. In 6 out of 29 subjects the post-contest biopsies ( $\mathrm{Be}_{\mathrm{s}}$ ) were taken within $\mathbf{3 5 \pm 8} \mathrm{min}$ after the marathon. In a second $(n=10)$ and third $(n=13)$ group of the subjects the biopsies were taken $278 \pm 40$ and $373 \pm 38$ min following the end of the marathon. As pointed out earlier, the reason for these differences was rather trivial.

The marathon contests were organized at different distances from the laboratory where the biopsies were routinely taken. The corresponding tissue glycogen levels were $136 \pm 36,172 \pm 53$ and $210 \pm 42$ umoi glucose moleties per gram dry weight, respectively. The p-values for the differences between the first and the second and the irst and the third group were 0.079 and 0.003 , respectively. 
These findings strongly suggest that glycogen resynthesis occurs within the first 6 hours following a marathon.

Summarizing, the present study has shown that training of initially untrained volunteers results in increased levels of ATP, GTP, GDP, $\mathrm{NAD}^{+}$, purine bases and glycogen in $\mathrm{m}$. vastus lateralis. From a biochemical point of view, running a 15,25 and $42 \mathrm{~km}$ contest after $6,11-14$ and 17-20 months after the start of the training programme respectively, has been tolerated very well. No substantial decrease in the tissue content of the metabolic co-factors could be monitored as a consequence of the contest. Only glycogen levels were affected. The content of this endogenous substrate store returned to (supra)normal levels when measured 9 days after the contest.

\section{Reterences}

1 Eriksson B.O., Gollnick P.D., and Saltin B.: Muscle metabolism and enzyme activities after training in boys 11-13 years old. Acta Physiol Scand 87:485-497,1973.

2 Evans W.J., Pinney S.D., and Young V.R.: Suction applied to a muscle biopsy maximizes sample size. Med Sports Exercise 14: 101-102,1982.

3 Gollnick P.D., Armstrong R.B., Saltin B., Saubert C.W., Sembrowich W.L., and Shepherd R.E.: Effect of training on enzyme activity and fiber composition of human skeletal muscle. J Appl Physiol 34:107-111,1973.

4 Graham T., Sjögaard G., Loellgan $H_{\text {., }}$ and Saltin B.: NAD in muscle of man at rest and during exercise. Pfuegers Arch 376:35-39,1978.

5 Hikida R.S., Staron R.S., Hagerman F.C., Sherman W.M., Costill D.L.: Muscle fiber necrosis associated with human marathon runners. J Neurol Sci 59: 185-203,1983.

6 Jansson E.: Acid soluble and insoluble glycogen in human skeletal muscle. Acta Physiol Scand 113:337-340,1981.

7 Jansson E., Kayser L.: Substrate utilization and enzymes in skeletal muscle of extremely endurance-trained man. J Appl Physilol 62:999-1005,1987.

8 Karlsson J., Nordesjoe L.O., Jorfeldt L., and Saltin B.: Muscle lactate, ATP, and CP levels during excercise after physical training in man. $J$ Appl Physlol 33:199-203,1972.

9 MacDougall J.D., Ward G.R., Sale D.G., Sutton J.R.: Biochemical adaptation of human skeletal muscle to heavy resistance training and immobilization. $J$ Appl Physiol 43:700-703,1977.

10 Meyer R.A., Dudley G.A., and Terjung F.L.: Ammonia and IMP in different skeletal muscle fibers after exercise in rats. J Appl Physiol 49:1037-1041,1980.

11 Näveri $H_{u}$, Kuoppasalmi K., and Härkönen M.: Metabollc and hormonal changes in moderate and intense long-term running exercises. Int $\mathfrak{J}$ Sport Med 6:276-281,1985.

12 Newsholme E.A." The glucose/fatty acid cycle and physical exhaustion. In: Human muscle fatique: physiological mechanisms. Pitman Medical, London, 1981, pp 89-101. 
13 Sherman W.M., Costill D.L., Fink W.F., Hagerman F.C., Armstrong L.E., Murray T.F.: Effect of $42.2 \mathrm{~km}$ foot-race and subsequent rest or exercise on muscle glycogen and enzymes. J Appl Physiol 55: 1219-1224,1983.

14 Sutton J.R., Toews C.J., Ward G.R., and Fox I.H.: Purine metabolism during strenuous muscular exercise in man. Metabolism 29:254-259,1980.

15 Tesch P.A., Colliander E.B., and Kaiser P.: Muscle metabolism during intense, heavy-resistance exercise. Eur J Appl Physiol 55:362-366,1986. 


\subsection{Histological changes associated with long distance training and running}

\section{Introduction}

Physical activity is generally regarded as beneficial to health. However, an adverse effect may be the occurrence of injuries. Especially runners are prone to get injured or to suffer from muscular overuse. Hikida et al. (5) reported histological changes in gastrocnemius muscles of runners who completed a marathon. However, they also observed histological changes in biopsy samples, taken before the race. In a previous study, only minor histological changes were found in the quadriceps muscles of athletes who participated in the marathon $(6,7)$. However, the athletes in the latter study ran at a recreational level whereas the athletes in the study by Hikida (5) ran the marathon at a higher average velocity. Hikida suggests that the training, associated with marathon running may also lead to muscle damage, reflected in morphological changes. Since the majority of the marathon runners are recreational runners, it is important to know whether overuse of the locomotor system can be prevented by a training programme in which the intensity as well as the volume are gradually increased in an undulating way. Therefore, the purpose of the present study was to monitor the histology of skeletal muscle in a number of male and female recreational runners who trained over a perlod of 18-20 months and ultimately ran a marathon. In Chapter 2 (p. 30,34) materials, methods and procedures concerning this part of the investigation have been described and a time survey of the protocol before and after each contest is given in Fig. 5.1.1 (p. 85).

\section{Materials and methods}

\section{Subjects}

The 36 subjects of the treadmill group (TG) (25 males and 11 females) participated in this study after giving written informed consent. The subjects had never run a distance over $12 \mathrm{~km}$ before entering the study and none of them ever competed in distance running. Their characteristics are presented in Table 2.3 on p 27. Results

Fiber types and fiber diameters were determined in the blopsy samples of 15 males and 8 females. The results are given in Table 5.2.1 and 5.2.2. Blopsy samples of 10 males and 3 females could not be used for morphological investigations due to a number of problems such as failing in one of the contests, too small sample size and freezing artefacts. In addition in 9 cases biopsies were not taken. 
Table 5.2.1 Type of fibers in the $\mathrm{m}$. vastus llateralls of male and female subjects before the $15 \mathrm{~km}$ contest

\begin{tabular}{lccc}
\hline & $\%$ type & $\%$ type $\|$ IA & \% type IIB \\
\hline males & $43 \pm 12$ & $44 \pm 15$ & $11 \pm 9$ \\
femalles & $49 \pm 8$ & $43 \pm 10$ & $6 \pm 4$ \\
Mean vallues $\pm s d$ & &
\end{tabular}

Histochemical analysis did not demonstrate significant shifts in the ratio between fiber types during the period (between $15 \mathrm{~km}$ and 42 $\mathrm{km}$ contest), nor was there a significant change in fiber diameter observed (Table 5.2.2).

Tablle 6.2.2 Mean dlameter of type I and type II flbers In males and females, before the varlous contests

\begin{tabular}{lllll}
\hline & $\begin{array}{c}\text { MALES } \\
\text { Type I }\end{array}$ & Type 11 & FEMALES & Type I \\
& & & & Type II \\
\hline $15 \mathrm{~km}$ & $61.0 \pm 10.1$ & $62.7 \pm 14.7$ & $63.5 \pm 12.5$ & $61.6 \pm 15.6$ \\
$25 \mathrm{~km}$ & $63.3 \pm 11.5$ & $61.5 \pm 12.5$ & $62.5 \pm 17.2$ & $62.7 \pm 12.9$ \\
$42 \mathrm{~km}$ & $62.9 \pm 13.5$ & $66.4 \pm 12.8$ & $62.1 \pm 12.8$ & $59.9 \pm 10.2$
\end{tabular}

Mean values $\pm s d(\mu \mathrm{m})$

No significant differences with respect to fiber types were found between males and females. Neither were any differences found between the mean dlameters or variation in diameters of type 1 and type II fibers.

Histochemical examination revealed that in none of the first biopsy specimen $\left(B_{1}\right)$ pathological changes existed. In the second sample $\left(B_{2}\right)$ the first pathological changes were observed, consisting of central nuclei. In the subsequent samples a gradual increase in pathological changes was observed (Table 5.2.3). The pathological changes were similar in nature and frequency in the female and male participants. The frequency of the changes before and after each contest were not different, thus no systematic increase in the pathological changes was found after a contest (Table 5.2.3). The pathological features were found in type I as well as in type IIA and IIB fibers and no preference for occurrence in a particular flber type was found. Combining these results with the PAS stain, a relationship between pathological features and intensity of the PAS stain could not be demonstrated.

Ultra structural examination demonstrated abundance of glycogen in the pre-race samples and the samples taken 8 days after the contests in comparison to the samples taken 0.5-6 $\mathrm{h}$ after the contest. The blopsy specimens taken immediately and 8 to 9 days after the marathon were observed irregular Z-lines and hypercontractions of the sarcomeres in the peripheral areas of the muscle fibers. No sarcolemmal damage or mitochondrial changes could be found (Fig. 5.2.1 to 5.2.5). 
Table 5.2.3 HIstologlcal changes in the blopsy samples.

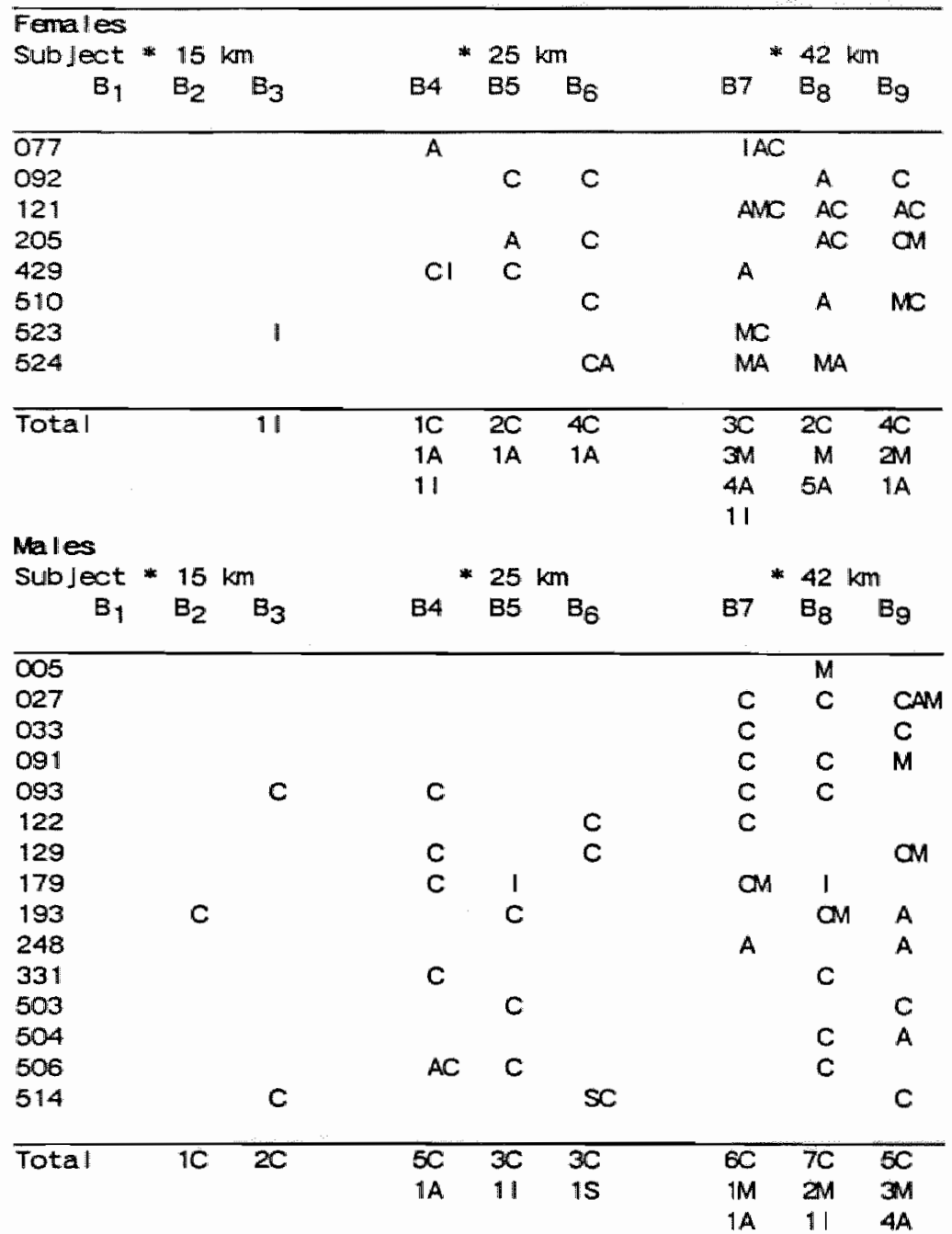

$B_{1}, B_{4}$ and $B_{7}$ are taken before the 15,25 and $42 \mathrm{~km}$ contest, respectively. $B_{2}, B_{5}$ and $B_{8}$ are taken $0.5-7 \mathrm{~h}$ after the 15,25 and $42 \mathrm{~km}$ contest, respectively. $B_{3}, B_{6}$ and $B g$ are taken $8-9$ days after the 15,25 and $42 \mathrm{~km}$, respect I vely.

$A=$ atrophic flbers; $C=$ central nuclel; 1 = Inflitration of macrophages: $M=$ myoblast $\mid c$ act $|v|$ ty and regenerat $I o n ; S=$ central splltting. * represents the contest. 


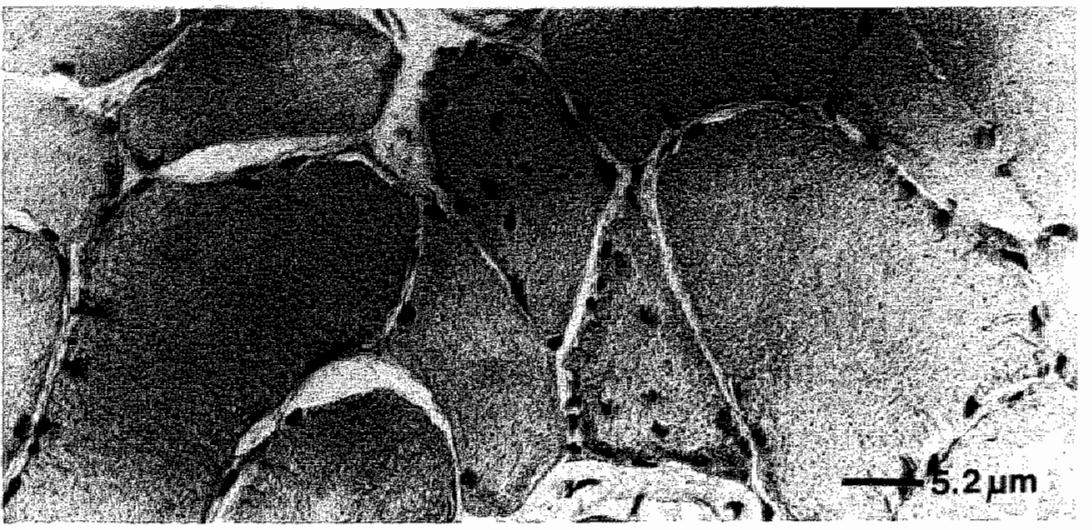

Flg. 5.2.1 Cross sectlon of $\mathrm{m}$. vastus lateralls Illlustrating central nuclel

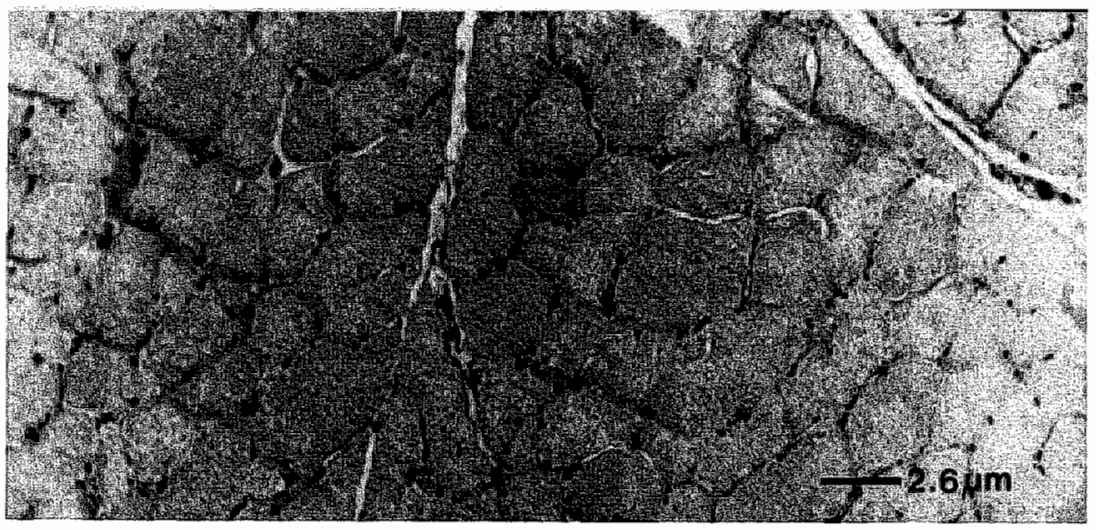

FIg. 5.2 .2 Cross section of $\mathrm{m}$. vastus lateralls with a basophlilc flber

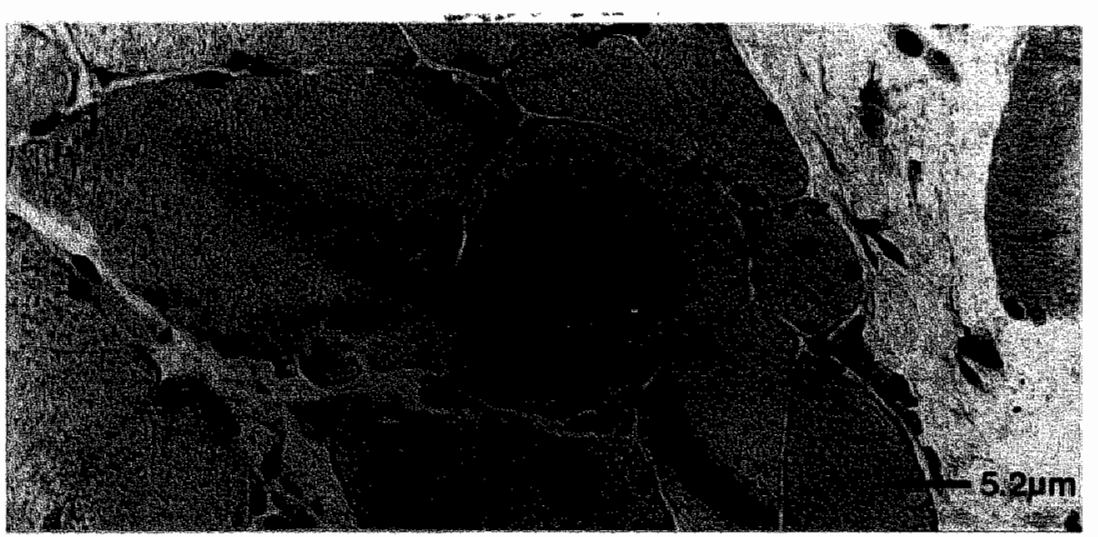

Fig. 5.2.3 Cross section of $\mathrm{m}$. vastus lateralls with an Internally silt fiber 


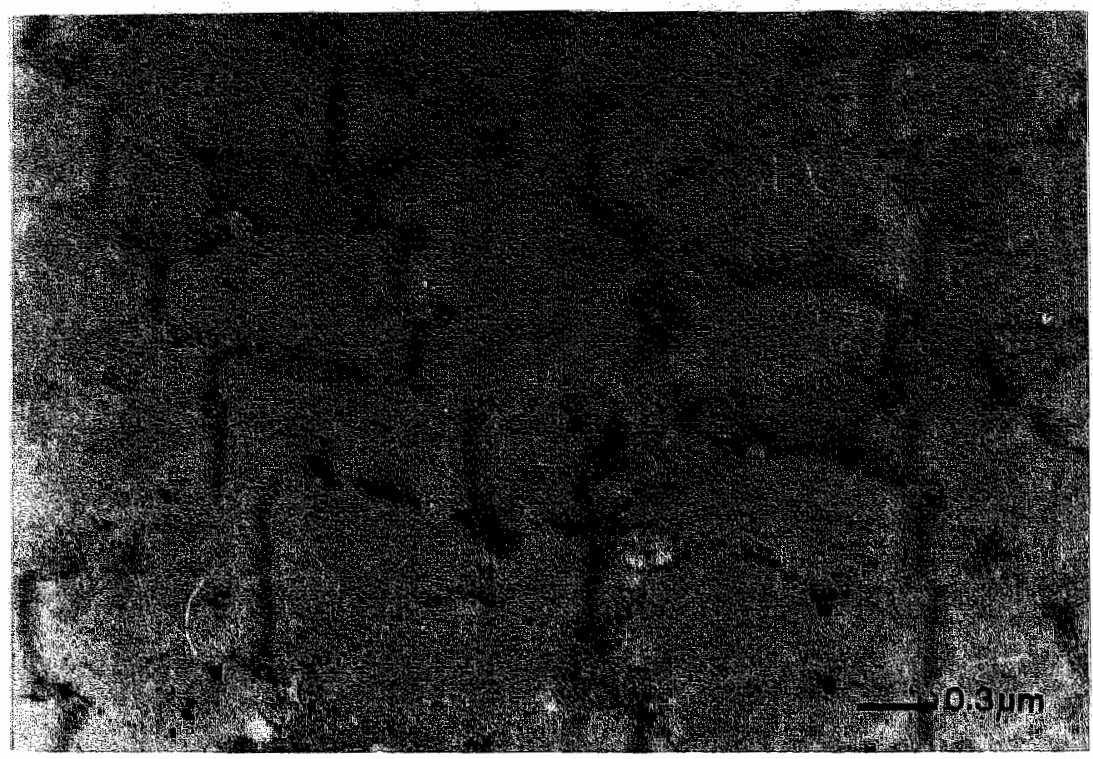

Fig 5.2.4 Cross section of $\mathrm{m}$. Vastus lateral is wlth Irregular Z-lines

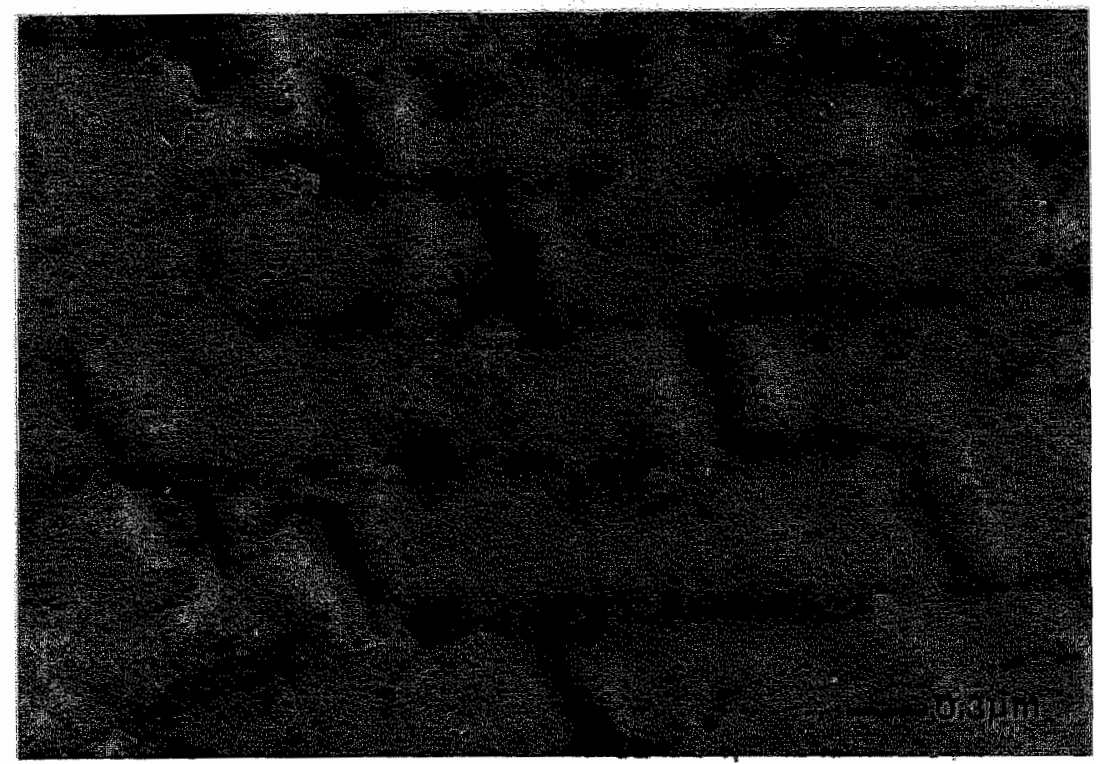

Fig 5.2 .5 Cross section of m. vastus lateralls with Irregular Z-lines 


\section{Discussion}

The present study demonstrates that the training for long distance running is as stressful as the contest itself, and is associated with pathological changes in the muscle fibers. Pathological changes were observed throughout the whole period. The changes were similar to those reported by Hikida et al. (5). These investigators, however, took muscle biopsles from the gastrocnemius muscle. The results of the present study and those from Hikida's study indicate that long distance running poses great stress on both the gastrocnemius and vastus lateralis muscle. Like Hikida's study, pathological changes were also found before the events. This indicates that training for long distance running is associated with pathological changes in the leg musclles which reflects a continuous degeneration and regeneration in skeletall muscle. The frequency of the abnormalities seems to increase with the length of the training runs, which suggests that the distance covered is an important factor for the occurrence of pathological changes in skeletal muscle. This is also supported by an earlier study in marathon runners who ran a $25 \mathrm{~km}$ race as well as a marathon. Less damage occurred after the $25 \mathrm{~km}$ contest whereas the average intensity was higher than during the marathon $(6,7)$. In the study by Hiklda et al. (5) Inflammatory changes appeared to be observed more frequently than in the present study. Warhol et al. (8) took blopsy samples from the gastrocnemius muscle after a marathon and found various forms of structural damage. However, no signs of locall inflammatory response were observed in muscle tissue after a marathon. Differences may be partly explained by the different muscle types examined, since other authors who examined muscle tissue after the marathon biopsied the gastrocnemius muscle, whereas in the present study muscle blopsies were taken from the vastus lateralis muscle. It is possible that the stress (metabolic and mechanical) posed on the gastrocnemius muscle is hilgher than that on the thigh muscles. However, most runners complain of more muscle soreness in the thigh muscles than in the calf muscles. Because of this the vastus lateralis was chosen in the present study. After the 25 and $42 \mathrm{~km}$ contest in 3 and 4 subjects respectively, biopsy samples were taken both from the vastus lateralls and gastrocnemius muscles. No difference in microscopic features were found between these muscle samples.

The results demonstrate that the pathological changes occur in all flber types. This is also the case in samples taken before the marathon as well as before the $25 \mathrm{~km}$ contest. This suggests that type I as well as type IIA and type IIIB in the vastus lateralis muscle are heavily involved in endurance running. No relatlonship between pathological features and PAS stain were found. This suggests that substrate avallability is not of primary importance for the occurrence of pathological changes. However, the size of muscle biopsy samples and the amount of abnormalities do not allow exclusion of the fact that substrate depletion is a primary factor for muscle damage when running long distances. Employing morphological and histochemical analysis, the consecutive muscle samples were analyzed for adaptive changes. No significant 
shift in fiber types was found, in contrast to the study by Andersen and Henriksson (1). These authors reported significant shifts from type IIB to type IIA fibers during endurance training.

Morphometrical examination failed to demonstrate significant changes in fiber diameters during training. Although no shift in fiber types or changes in fiber dimensions were observed, it cannot entirely be excluded that changes did occur, since the first biopsy was taken after completion of the first period of training ( 6 months). The fiber diameters of the male subjects were similar to those of sedentary men (4) and no selective hypertrophy was found. In the female runners the mean fiber diameters were larger than in sedentary women (4). Simllar dimensions of male and femalle muscle fibers were in keeping with the results of a study of Costill et all. (3). However, their female runners had smaller type II fibers than their male counterparts. This discrepancy may be explained by the different muscles used: the vastus lateralis muscle in the present study versus the gastrocnemius muscle in the study by costill et al. (3). In well trained female cyclists similar dimensions of type I and type II fibers have been reported by Burke et al. (2).

In conclusion, training for long distance running is associated with transient minor pathological changes in skeletal muscles. The extent of the changes is related to the training distance rather than to the intensity of the exercise.

\section{Reterences}

1 Andersen P., Henriksson J.:. Training induced changes in subgroups of human type II skeletal muscle fibres. Acta Physiol Scan 99:123-125,1977.

2 Burke E.R., Cerny $F_{\text {, }}$ Costill D.L., Fink W.: Characteristics of skeletall muscle in competitive cyclists Med Sci Sports 9: 109-112,1977.

3 Costill, D.L., Daniels J., Evans W., Finks W., Krahenbuhl G., Saltin B.: Skeletal muscle enzymes and fiber composition in male and female track athletes. J Appl Physiol 40(2):149. $154,1976$.

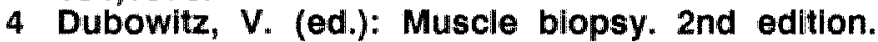
Bailliere Tindall, London, Philadelphla 1985.

5 Hikida, R.S., Staron F.S., Hagerman F.C., Sherman W.M., and CostillD.L.: Muscle fiber necrosis associated with human marathon runners. J Neurol Scl 59:185-203,1983.

6 Janssen, G.M.E., Kulpers H., Verstappen F., Keizer H.: Muscle damage and recovery after a marathon compared to a $25 \mathrm{~km}$ race. Med. Scl. Sports Exercise (abstract) 16:200,1984.

7 Janssen G.M.E., Kuipers H., Kelizer H.A., Geurten P.,

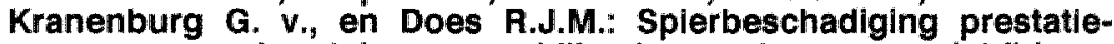
vermogen en herstel na verschillende soorten wegwedstrijden. Gen en Sport 20(5):191-195,1987.

8 Warhol, M.J., Siegel A.J., Evans W.J., and Silverman L.M." Skeletal muscle injury and repair in marathon runners after competition. Am J Pathol 118:331-339,1985. 


\begin{abstract}
5.3 Activity of plasma creatin phosphokinase, L-aspartate aminotransferase, L-alanine aminotransterase and the quantification of skeletal muscie damage associated with 15,25 , and $42 \mathrm{~km}$ contests and exercise tests
\end{abstract}

\title{
Introduction
}

The mechanism of muscle enzyme leakage has not yet been established although there are indications that mechanical, metabolic and thermal stress may result in an increased plasma muscle enzyme activity $(7,19,20,21,42)$. The degree of enzyme leakage is generally acknowledged as a measure for increased sarcolemmal permeability and muscle damage $(3,4,5,7,9,10,12,17,18,21,22,23,27$, $30,33,41,42)$. During running the mechanical stress seems to be an important factor in eliciting leakage of muscle enzymes. It is very difficult to identify the primary factor. In physical training or exercise (contests) various factors may elicit muscle enzyme leakage such as: distance to be covered, speed, Intensity, temperature, style of running (impact), the way of training and training status $(22,26$, 29,31). Some training variables like training status, style of running and a good training may prevent the occurrence of enzyme leakage. Others, such as distance, speed and intensity are assumed to enhance the leakage of muscle enzymes. Other aspects with regard to muscle enzyme leakage are the individual nature of the muscle and gender $(6,13,21,24,25,32)$. In the present investigation a number of variables were kept as constant as possible for all the subjects, i.e. training status, distance to be covered, way of training, and training experience. Factors which cannot be influenced are gender, individual muscle quality and adaptation to training.

The aim of the present study was to determine the change of plasma activity of the muscle enzymes Creatin phosphokinase (CK), and L-Aspartate aminotransferase (Asat), and of the liver enzyme L-Alanine aminotransferase (Alat). We studied the activities of these enzymes in males and females before and after three contests $(15,25$ and $42 \mathrm{~km})$. To investigate whether sarcolemmal permeability is affected for a longer perlod of time after a contest the plasma activity of Alat, Asat and CKK was determined not only after each contest but also after the 3 physical exercise tests $T_{1}, T_{2}$ and $T_{3}$ (Fig. 4.1.1; p. 57).

In particular the following aspects were studied:

- Influences of the three contests and the physical exercise tests $T_{1}, T_{2}$ and $T_{3}$ on plasma enzyme activity.

- The influence of training adaptation in the course of the study on enzyme leakage.

- Plasma activity of muscle enzymes CK and Asat as a function of the running distance.

- Half-life time $\left(t_{*}\right)$ of CK, calculated from the slope of the log plot of the enzyme activity, assuming first order elimination 
kinetics. The plot was constructed using the enzyme activity determined in plasma samples 6 to 9 after the contests.

- A quantitative approach to the leakage of muscle enzymes CK and Asat. The quantitative approach was based on cumulative leakage of enzymes. The cumulative leakage was calculated using the sum of the plasma activity of a muscle enzyme, the rate of degradation (fractional catabolic rate $=$ FCR) and the activity in the extravascular compartment. The activity in the extravascular compartment was determined by the transcapillary cumulative disappearing rate (TER) and the diffusion speed of the enzyme from the extravascular into the vascular compartment (ERR) $(15,38,39,40)$.

- Relationship of plasma activity of CK and Asat with other variables such as performance time, change in performance (quotient of performance of exercise test $T_{2}$ and $T_{1}$ ), speed intensity index $\left(S \| I=V_{0} .\left(V_{\pi r}\right)^{-1.100 \%)}\right.$ and heart intensity index $\left(\mathrm{H} \| \mathrm{I}=\mathrm{H}_{\mathrm{c}} \cdot\left(\mathrm{H}_{\mathrm{T}}\right)^{-1} .100 \%\right.$ ) (Chapter 2;p. 36).

- Difference in plasma muscle enzyme response after the contests between malles and females.

\section{Results}

Plasma activity of muscle enzymes after contests, physical exercise tests and after training

\section{L-Alanine aminotransferase (Alat)}

The activity of the enzyme Alat in samples 5 to 9 after the three contests showed only a slight change compared with sample 1 to 4 (Table 5.3.1). Three days after the 15 and the $25 \mathrm{~km}$ contest the activity of Alat had returned to pre-contest level. After the marathon the increase of Alat activity remained for seven days before returning to the pre-contest levell. Some subjects showed remarkably elevated values (30-60 U.1-1) during the whole training period. After the physical exercise tests there was no signiflicant change of Allat in males and females.

In the course of the training the Alat plasma activity had decreased significantly in samples 1 to 4 before the $25 \mathrm{~km}$ and $42 \mathrm{~km}$ contest in comparison with the activity in sample 1 to 4 before the $15 \mathrm{~km}$ contest in males and in temales $(15 \mathrm{~km}$ vs $25 \mathrm{~km}: M \quad p=0.019, F p=0.038$; 15 vs $42 \mathrm{~km}: M \quad p=0.036$, F $p=0.008)$.

\section{L-Aspartate aminotransferase (Asat)}

No increase of Asat activity in plasma was demonstrated after the exercise test $\left(T_{1}\right)$ before the three contests. However, there was a pronounced increase in plasma activity of Asat after the three contests in males and females ( $p$ varied from $<0.0001$ to $<0.03$ ). Besides, the plasma activity was higher when the contest lasted longer (Table 5.3.1). The plasma activity of Asat after the $42 \mathrm{~km}$ contest was significantly higher than after the 15 and $25 \mathrm{~km}$ contest in males and females (42km vs 15km:M $p<0.0001, F p<0.041$ and $42 \mathrm{~km}$ vs $25 \mathrm{~km}: \mathrm{M} p=0.005, F p=0.037)$. 
Table 5.3.1 Plasma activity of $\mathcal{K}$, Asat and Alat before and after the contests in males and females

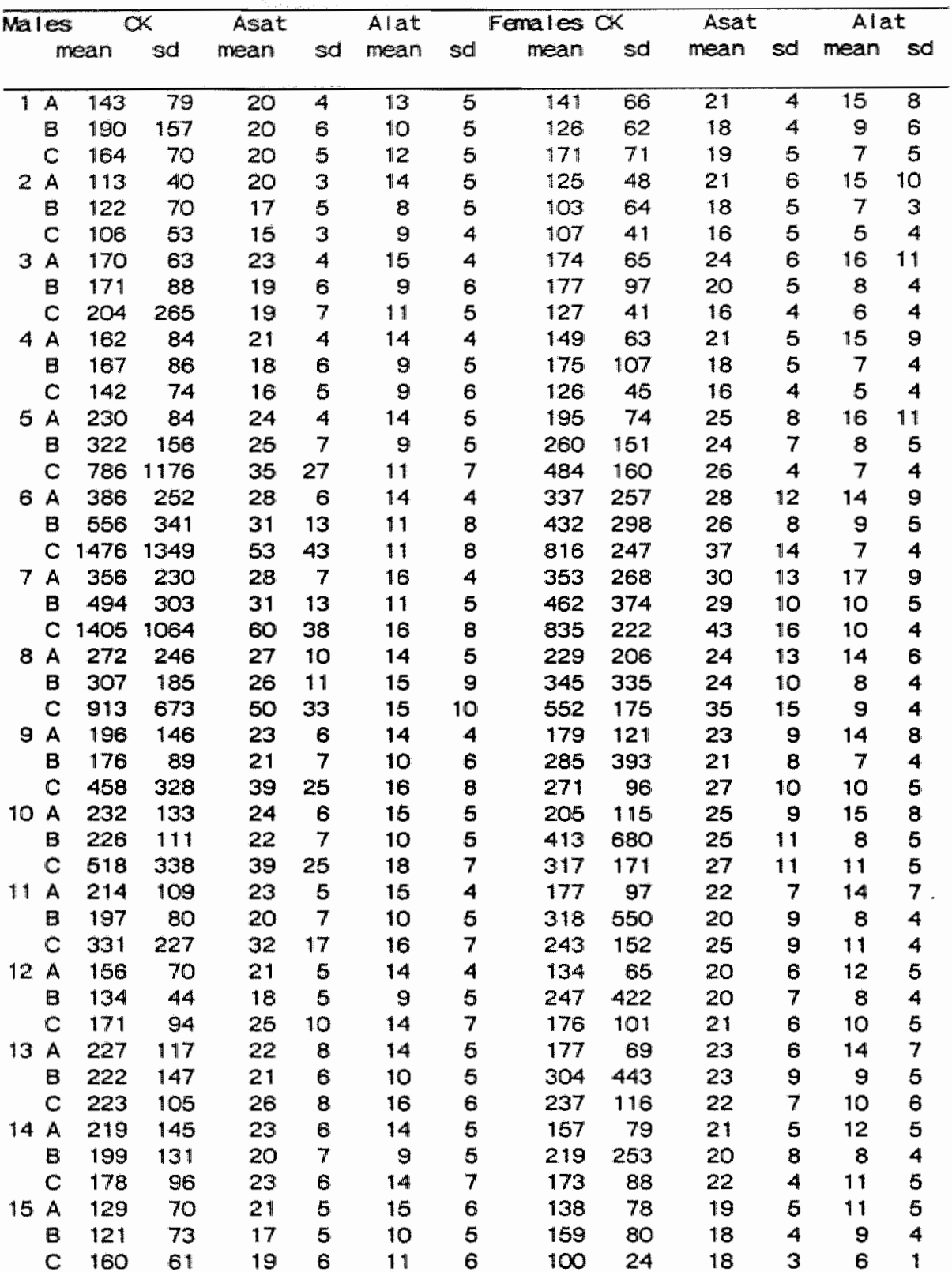

Mean values \pm so of the enzymes $O K\left(U .1^{-1}\right)$. Asat $\left(U .1^{-1}\right)$ and Alat $\left.(U .)^{-1}\right)$ in the samples taken before and after the $15 \mathrm{~km}$ (A), the $25 \mathrm{~km}$ (B) and the $42 \mathrm{~km}$ contest (C). Time axis of samples nrs. 1-15 is shown In Fig. 4.1 .1 (p. 57). 
Concerning training adaptation (samples 2 and 4 before each contest) it appeared that the plasma activity of Asat decreased in the course of the training period in males and females $(15 \mathrm{~km}$ vs $25 \mathrm{~km}$ and $15 \mathrm{~km}$ vs $42 \mathrm{~km} p<0.05$ ).

However, after the 15 and $42 \mathrm{~km}$ contest there appeared to be a gender difference in plasma Asat activity; the increase in plasma activity of Asat (sample 6) was significantly higher in males than in females ( $15 \mathrm{~km}: p=0.003,42 \mathrm{~km}: p=0.037$ )

\section{Creatin phosphokinase (CK)}

The increase of plasma activity after exercise test $T_{y}$ before the 15

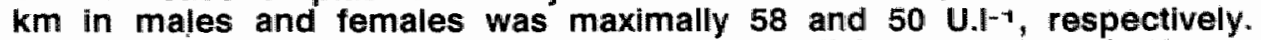
After $T_{1}$ before the $25 \mathrm{~km}$ the $C K$ plasma activity was 48 and 74 U. I- $\left.\right|^{-1}$, and after $T_{1}$ before the $42 \mathrm{~km} 44$ and $15 \mathrm{U.ll-1}$, respectively. In the plasma samples taken after the contests there was a pronounced increase in plasma CK activity after all the contests both in males and females (Tablle 5.3.1). The increase in CK activity was higher with increasing distance of the contest.

The plasma CK activity before each contest (sample 1 to 4 ) did not decrease during the training period.

The increase in plasma CK activity appeared to be higher in males than in females after the 15 and the $42 \mathrm{~km}$ contest $(p<0.01)$. In plasma samples taken before and after the $25 \mathrm{~km}$ contest there was no gender difference in plasma CK activity.

A renewed increased enzyme activity after the physical exercise tests $T 2$ and $T 3$ compared to $T 1$, did not appear in any of the enzymes $(17,18)$.

The relationship between the increase in activity of Asat and CK and running distance

The increase in activity is defined as the difference of the plasma activities of the samples taken after the contest and the mean basic level, lie. the mean value of samples 2 and 4 . A large range in activity increase of Asat and $C K$ in plasma after the 15, 25 and $42 \mathrm{~km}$ contests was observed both in males and females (Fig. 5.3.1 and Fig.5.3.2). The plasma activity pattern of CK and Asat in relation to the contest distance was different in males and females. A regression analysis was applied to the mean increase of the plasma activity of CK or Asat (Table 5.3.2) with the distance of the contest.

Table 5.3.2 Relatlonship between the mean values of $\mathrm{CK}$ and Asat and contest distance $(15,25$ and $42 \mathrm{~km}$ ) in males and females

\begin{tabular}{|c|c|c|c|c|c|c|c|c|}
\hline \multirow{4}{*}{ R-sq (\%) } & \multicolumn{4}{|c|}{ 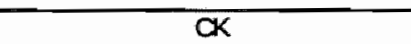 } & \multicolumn{4}{|c|}{ Asat } \\
\hline & \multicolumn{2}{|c|}{ males } & \multicolumn{2}{|c|}{ ferna les } & \multicolumn{2}{|c|}{ malles } & \multicolumn{2}{|c|}{ females } \\
\hline & A & B & A & B & A & $B$ & A & B \\
\hline & 82.5 & 93.7 & 95.9 & 95.4 & 87.7 & 91.6 & 96.6 & 97.6 \\
\hline
\end{tabular}



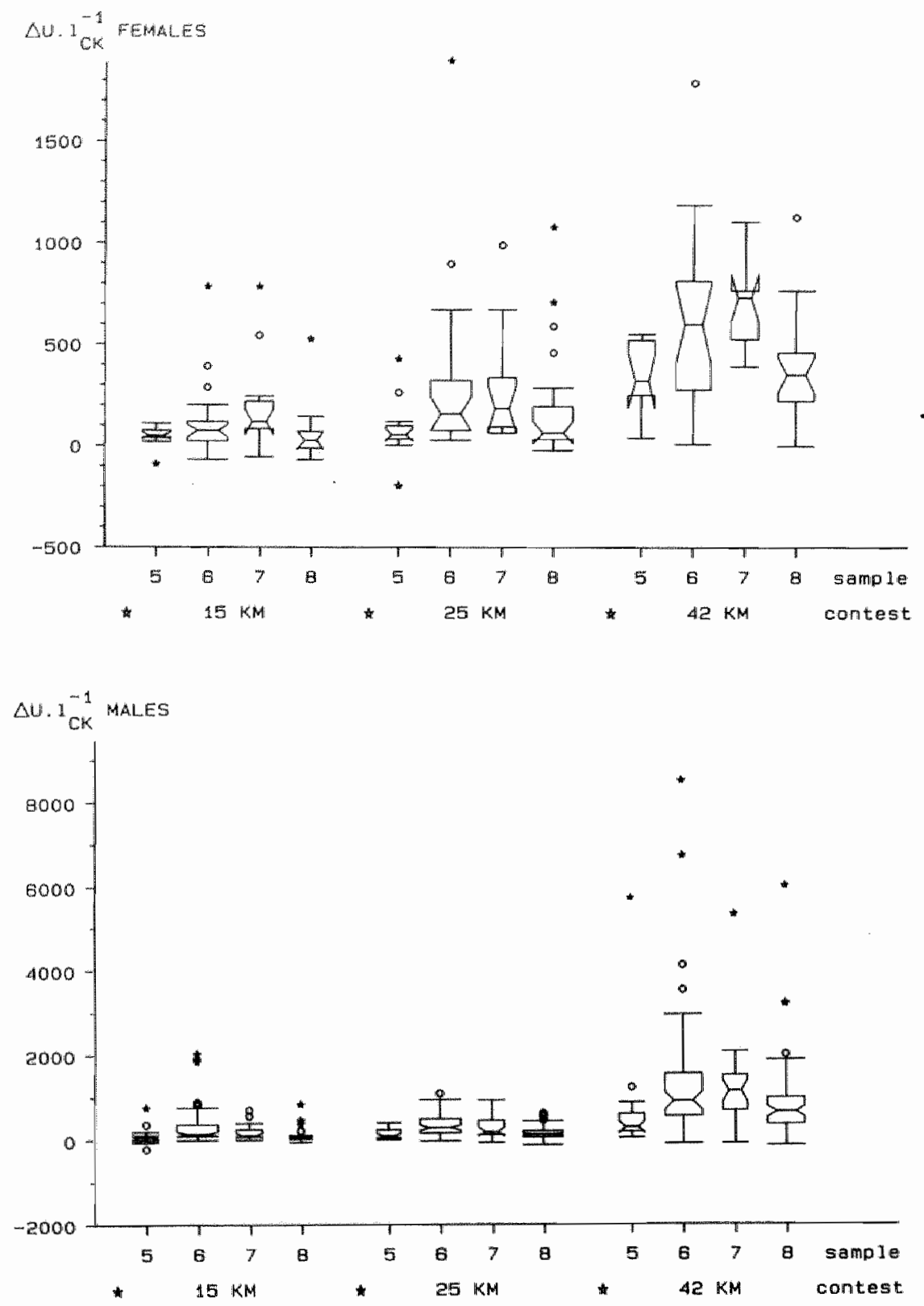

Flg. 5.3.1 Increases in OK plasma activity after the 15,25 and $42 \mathrm{~km}$ contest $w /$ th respect to the baslc level (mean of sample $2+4$ ) of sample 5 to 8 are demonstrated using box-and-whisker plots. 

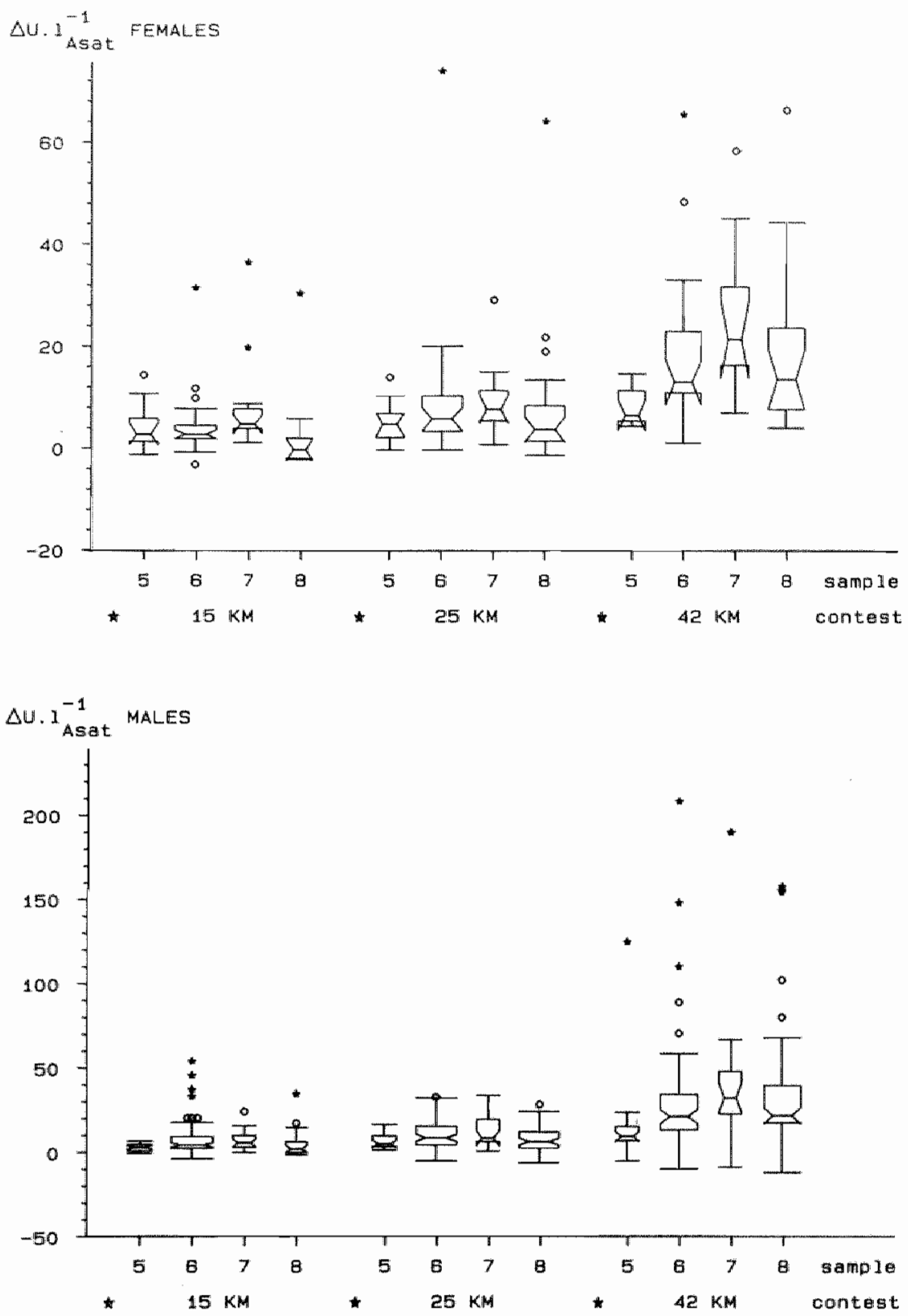

FIg. 5.3.2 Increases In Asat plasma act |vity after the 15, 25 and 42 $\mathrm{km}$ contest w/th respect to the baslc level (mean of sample 2+4) of sample 5 to 8 are demonstrated using box-and-whisker plots. 
In males an exponential fit characterized the relationship between the mean plasma $C K$ and Asat activity due to the three contests somewhat better than a linear one. In females it appeared that a linear increase fits well for all three contests.

\section{The half-life time $\left(t_{1}\right)$ of CK after the contests}

In males and females the $t_{1 / 2}$ of $C K$ was determined using the values of the samples 5 to 9 atter each contest. In Table 5.3.3 the calculations of mean $t_{i, s}$ of $C K$ in males and females are listed. The $t_{1 / m}$ declined significantly in the course of the training period in males and females $(p<0.02$ and $p<0.05$, respectively). No significant gender difference was noticed.

Table 5.3.3 Half-I ife $t$ ime $\left(t_{1 / 2}\right)$ values of $C K$ after

15,25 , and $42 \mathrm{~km}$ contests

\begin{tabular}{cccc}
\hline & $15 \mathrm{~km}$ & $25 \mathrm{~km}$ & $42 \mathrm{~km}$ \\
\hline males & $21.1 \pm 11.5$ & $15.0 \pm 6.0$ & $13.4 \pm 4.9$ \\
females & $20.8 \pm 7.0$ & $16.1 \pm 5.8$ & $12.1 \pm 4.1$
\end{tabular}

Mean values $\pm s d(h)$

Quantltative approach of leakage of CK and the content of CK In the $\mathrm{m}$. vastus laterallis

Because of the very high correlation between the plasma activities of Asat and CK (15km: $r=0.89,25 \mathrm{~km}: r=0.85$ and $42 \mathrm{~km}: r=0.90)$, the cumulative activity was only calculated for CK. The quantity of the enzyme activity in plasma was calculated according to the equation of Willems et all. $(38,39,40)$ and is summarized in Table 5.3.4. The cumulative activity of $\mathrm{CK}$ is built up from the activity from sample 4 to sample 9 as reponse to the contests and from sample 9 to 14 as reponse to the exerclse tests $T_{2}$ and $T_{3}$, respectively.

Table 5.3.4 Cumulat lve plasma actIvlty of CK after the 15 , 26 and $42 \mathrm{~km}$ contests and after the exercllse tests $T_{2}$ and $\pi_{3}$

\begin{tabular}{lrcrcc}
\hline & \multicolumn{2}{c}{ males } & & \multicolumn{2}{c}{ females } \\
contest & A & B & A & $B$ \\
\hline $15 \mathrm{~km}$ & $2618 \pm 2441$ & $1500 \pm 1260$ & $2394 \pm 2665$ & $1099 \pm 1104$ \\
$25 \mathrm{~km}$ & $3487 \pm 2414$ & $1250 \pm 660$ & $3191 \pm 3429$ & $2502 \pm 6212$ \\
$42 \mathrm{~km}$ & $11899 \pm 11105$ & $2164 \pm 2035$ & $6420 \pm 2212$ & $1673 \pm 1743$
\end{tabular}

Mean values \pm sd $\left(U .1^{-1}\right)$

A cumulative activity of CK in samples 4-9 (response to contests)

$B=$ cumulative activity of $C K$ in samples 9-14 (response to exerclse tests)

The cumulative activity of CK (sample 4 to 9) showed no significant difference between the $15 \mathrm{~km}$ and $25 \mathrm{~km}$, nelther in males nor in temales. However, the CK cumulative activity both in males and females after the $42 \mathrm{~km}$ contest was signiflcantly higher than 
the cumulative activity after the two other contests $115 \mathrm{~km}$ vs $42 \mathrm{~km}$ : $p=0.0015$ and $p<0.0001$, respectively and 25 vs $42 \mathrm{~km}: p=0.028$ and $p=0.020$, respectively).

Only after the $42 \mathrm{~km}$ contest together with the exercise tests $T$ and $T_{3}$ there was a gender difference in CK activity (sample 4 to 9; $p=0.04$ and sample 4 to $14 p=0.001$ ) and a tendency to significant difference of the cumulative activity of sample 9 to $14 \quad(p=0.056)$. The amount of damaged muscle (g) can be calculated from cumulative activity, plasma volume and the activity of muscle enzyme (CK) per gram muscle tissue of an individual. The plasma volume was estimated to be $4.5 \%$ of body weight (11). The average calculated plasma volume in males was $3.21 \pm 0.28 \mathrm{I}$ and in temales $2.65 \pm 0.31 \mathrm{l}$. When the individual cumulative activity was multiplied by the Individual plasma volume yielding the total absolute activity in $U$ a gender difference was observed only after the $42 \mathrm{~km}$ contest $(\mathrm{p}<0.001)$.

The muscle content of CK was determined (8) before and after the 15 and $42 \mathrm{~km}$ contests (Table 5.3.5).

Table 5.3.5. OK-content in the $m$. vastus lateral Is before the 15 and $42 \mathrm{~km}$ contest

\begin{tabular}{lccccc}
\hline contest & $(n)$ & males & $(n)$ femalles & $(n)$ total \\
\hline $15 \mathrm{~km}$ & 20 & $308 \pm 60$ & 6 & $264 \pm 60$ & $26298 \pm 62$ \\
$42 \mathrm{~km}$ & 16 & $309 \pm 61$ & 9 & $282 \pm 39$ & $25299 \pm 54$
\end{tabular}

mean values $\pm \mathrm{sd}$ ( $|\mathrm{mol}, \mathrm{m}| \mathrm{n}^{-1} \cdot \mathrm{g}^{-1}$ wet welght)

$n=$ number of subjects

Nelther In males nor in females was there a change in CK-content of the $\mathrm{m}$. vastus lateralis due to training between the $15 \mathrm{~km}$ and the $42 \mathrm{~km}$ contest.

Because of the different methods employed for determining the muscle enzyme activity in plasma (Chapter 2, p. 33) and muscle tissue (8), both methods were compared for 7 tissue samples. The correlation coefficient between these methods was $r=0.87$. The data of the content of CK activity in muscle were recalculated using a correction factor obtained from this comparison $(35,36,37)$.

From the data of the cumulative activity in units and the data of tissue CK content in units per gram muscle (wet weight), it is possible to estimate the amount of damaged muscle (Table 5.3.6), assuming that the damaged muscle released the whole CK-enzyme content.

The percentage of damage was calculated by dividing the amounts of damaged muscle tissue (g) by the total mass of muscle multiplied with 100 . Muscle welght was assumed to be $45 \%$ of the body welght in males and $40 \%$ in females. The muscle damage expressed in grams of tissue demonstrated no gender differences. After the $42 \mathrm{~km}$ contest in males and females a significantly higher muscle damage was observed than after the two other contests $(15 \mathrm{~km}$ vs $42 \mathrm{~km}$ : $M p=0.0012, F p=0.0109$ and $25 \mathrm{~km}$ vs $42 \mathrm{~km}: M \quad p=0.001, F p=0.0663)$. 
Table 5.3.6 Calculated amount of muscle damage after the three contests.

Males gram $0 / \infty$ Females gram $0 / \infty$

meant sd $m / n$ max meant sd meant so min max meant sd

\begin{tabular}{lllllll}
\hline A $2.05 \pm 2.41$ & $(0.18-7.00)$ & $0.06 \pm 0.08$ & $1.74 \pm 1.68$ & $(0.14-3.02)$ & $0.07 \pm 0.07$ \\
B $2.19 \pm 1.97$ & $(0.34-7.45)$ & $0.07 \pm 0.06$ & $2.71 \pm 3.02$ & $(0.80-9.40)$ & $0.11 \pm 0.12$ \\
C $7.13 \pm 5.15$ & $(1.32-19.64)$ & $0.22 \pm 0.17$ & $4.62 \pm 2.23$ & $(1.78-9.14)$ & $0.20 \pm 0.09$
\end{tabular}

Mean vallues $\pm \mathrm{sd}$ and $\mathrm{m} / \mathrm{n}$ Imum and maximum values (gram tissue)

Mean values \pm sd ( $\%$ of muscle tissue mass)

$A, B$ and $C$ represent the 15,25 and $42 \mathrm{~km}$, respect I vely

Correlation of plasma CK and Asat activity with achievement of the contests, decrease in performance, SII, HII, urea, cortisol, testosterone and DHEAS

The correlation coefficient between plasma activity of Asat the day after the $15 \mathrm{~km}$ contest with SII was $0.35(p=0.001)$ in males and $0.34(p=0.05)$ in femalles. The correlation coefficient between plasma activity of Asat and performance time in min of the $15 \mathrm{~km}$ contest was $-0.32(p=0.003)$ in males and $-0.32(p=0.070)$ in females. In males and in females no significant correlation was found between plasma activity of CK with achievement, SII and HII.

The correlation of the increase of plasma CK activity (sample 6-4) with testosterone concentration $(r=0.52$ and $p=0.005)$ and DHEAS concentration $(r=043$ and $p=0.022)$ was only significant in females. The increase of plasma Asat activity showed similar results.

In males the increase in plasma CK activity on the day after the 42 $\mathrm{km}$ contest (difference of sample 6 and 4) was significantly correlated with a decrease in performance $(r=0.23 ; p=0.048)$ and achievement (performance time; $r=-0.24 ; p=0.038$ ). In females a similar Increase was found, with a correlation coefficlent of 0.49 $(p=0.027)$ and $-0.40(p=0.070)$, respectively.

Plasma Asat activity after the $42 \mathrm{~km}$ contest demonstrated similar results.

No significant relationship was found between the activity of Asat and $C K$ and HII during the marathon either in males or females.

Correlation between muscle damage and achievement, decrease in performance, SII, HII, urea, cortisol, testosterone and DHEAS

The correlation between muscle damage due to the $15 \mathrm{~km}$ contest and the variables SII, urea, and the hormones were not significant in males. In females there was a positive correlation between muscle damage and urea concentration $(r=0.60 ; p=0.044)$ and the hormones testosterone $(r=0.66 ; p=0.026)$ and DHEAS $(r=0.67 ; p=0.025)$ 14-16 $\mathrm{h}$ after the contest (sample 6). 
After the $25 \mathrm{~km}$ contest there were no significant relationships between muscle damage and the chosen varlables except in females for plasma urea concentration $(r=0.65 ; p=0.028) \quad 14-16$ hours after the contest (sample 6) "

After the marathon there was a positive correlation between the muscle damage and SII in males $(r=0.55 ; p=0.022)$ and a negative correlation with the achievement (time in min) in the contest $(r=-0.49$ and $p=0.017$ ) and a (one-way) significant negative correlation $(r=-0.39$ and $p=0.041)$ between muscle damage and the test performance decrease $\left(T_{2} / T_{1}<1.00\right)$. Besides, in males there was a tendency for a significant relationship between the testo- sterone concentration (sample 6) and muscle damage.

In females there was also a (one-way) negative correlation between the muscle damage and the test performance $\left(T_{2} / T_{1}\right) \quad(r=-0.48$; $p=0.047$ ). Besides, in females there were positive relationships between HIII $(r=0.75 ; p=0.05)$ and the plasma urea concentration $(r=0.85 ; p=0.016)$ and the testosterone concentration $(r=0.93 ; p=0.003)$ 14-16 hours after the marathon.

\section{Discussion}

\section{Activity of muscle enzymes}

The increase in plasma activity of the enzymes Asat and CK is most problably due to leakage from skeletal muscle, because the plasma activity of Alat, a liver enzyme, remained nearly constant during the test period. Other investigators also found that an increase in the plasma activity of muscle enzymes can be used to judge skeletal muscle damage after long lasting physical stress $(2,3,14$, $16,21,28,41)$. In the present investigation the muscle enzymes Asat and $C K$ appeared to behave similarly before and after $a 15,25$ and $42 \mathrm{~km}$ contest with a high correlation coefficient $(r=0.89,0.85$ and 0.90 , respectively; $p<0.0001$ for each $r$ value).

The muscle enzyme Asat indicates response already through a slight increase in plasma activity after physical stress in contrast to the larger increases in plasma $C K$ activity. The range of plasma $C K$ activity is, probably due to a higher activity in muscle tissue, larger than the Asat activity (21). A decrease in plasma activity of Asat and CK to individual normal values, which can be seen as a measure for recovery from damage of skeletal muscle, takes 5-8 days depending on the physical stress of the contest. However, a normal level of the muscle enzymes CK and Asat does not guarantee complete recovery (21).

\section{Training adaptation}

The significant decrease of basic plasma activity level (mean of sample 2 and 4) of Asat and Alat during the training periods 2 and 3 (from the $15 \mathrm{~km}$ contest untill the $42 \mathrm{~km}$ contest) is remarkable as it might be expected that cue to more physical stress a higher turnover of cells would occur (21). A similar behaviour of CK plasma activity was not demonstrated, possibly due to the large spread of basic levels in plasma activity. A reason for the decrement in plasma activity of Asat might be the increase of physical stress tolerance (21). 
Curve-fitting

The relationship between the increase in $C K$ and Asat plasma activity after the contests and the contest distances was linear for Asat in males and females and for CK in females. However, in males for $\mathrm{CK}$ a somewhat better fit was obtained for an exponential function. The increase due to the $42 \mathrm{~km}$ was for CK more than a factor 2 higher than the calculated value supposing a linear relationship. If the plasma CK activity is indeed a measure of physical stress, the physical stress after a marathon seems to be larger than expected supposing a linear relationship. A similar behaviour of plasma CK was demonstrated in a study about the difference between a $35 \mathrm{~km}$ contest and a marathon $(16,17)$. It looks as if a threshold for enzyme release is passed somewhere between 25 and $42 \mathrm{~km}$, which is also reported by Haralamble (14). In the present study this threshold manifested itself earlier than in the study of Haralambie (14).

In females a linear relationship was found in all three contests.

\section{Gender differences}

The plasma enzyme activities of CK, Asat and Alat in a "rest" situation, as in samples $1,2,4,14$ and 15 , were similar for the two sexes. Besides, there were no differences in $t_{1 / 2}$ of $C K$, in training adaptation with repect to the activity of Asat and Alat and in the differences between CK and Asat plasma activity in individuals after the three contests. However, the mean plasma activities after the 15 and $42 \mathrm{~km}$ contest were larger in males than in females. A llarger cumulative CK activity in males than in females was only observed after the $42 \mathrm{~km}$ contest in females. There was a gender difference in plasma activities of CK and Asat after the contests (15, 25 and $42 \mathrm{~km}$, respectively) and in curvefitting of the distance of the three contests as well.

It seems too simple to ascribe these gender differences to the difference in muscle mass between males and females or to the difference in running velocity during contests. Important is that the gender differences in plasma activity occurred after a certain threshold in physicall stress. Relationship with other variables, such as hormone concentrations, might give more insight Into the gender differences found. We observed for instance a positive relationship between the amount of damaged muscle and the testosterone concentration In plasma after the 15 and $42 \mathrm{~km}$ contests.

Half-life time value

A remarkable aspect of the present study is the decrease of $t_{1 / s}$ for CK activity from about $21 \mathrm{~h}$ to about $12.5 \mathrm{~h}$ in the course of the training. Possible reasons for this decrease are the increase of the catabolic rate due to training, an increase of the blood flow in the splanchnic area or an increase of liver function. Wolf postulated the possibility of a more efficient. production of ATP, which leads to a retarded release of enzymes (41).

Rogers et al. (25) have found a $t_{1 / 3}$ of CK of $30.4 \mathrm{~h}$ and $29.4 \mathrm{~h}$ in males and females, respectively after running a marathon. These $t_{t / 4}$ values were higher than the results of the present study, in which 
the tw values after the marathon were $13.4 \pm 4.9 \mathrm{~h}$ in males and $12.1 \pm 4.1 \mathrm{~h}$ in females, respectively. However, in the quoted study there was no clear report of dally physical exercise after the marathon. In the present study no physical exercise was done before the standardized physical exercise test $\left(T_{z}\right) 3$ days after each contest. The performances of the subjects of the study of Rogers et al. (1161-216 min) suggest that their subjects had a similar or better training status than the subjects in the present study. A reason for the difference in cllearance after the marathon could be renewed activity in daily physical exercise after the marathon.

\section{Renewed-activity}

The increase in CK and Asat plasma activities due to physical exercise tests $T_{2}$ and $T_{3}$ after the 15,25 and surely after the $42 \mathrm{~km}$ contest was expected to be higher than the increase after the exercise test $T_{1}$ before the contests $(16,17)$. This did not appear to be the case. Possibly the stress of the treadmill test as employed in this study was not large enough for the recreational runners to elicit a renewed leakage $(16,17)$.

\section{Cumulative leakage}

The cumulative activity of muscle enzymes appeared to be significantly higher after the $42 \mathrm{~km}$ contest than after the 15 and $25 \mathrm{~km}$ contests. There was also a difference between males and females, which became only significant when the cumulative activity of $C_{K}$, expressed in units per liter, was multiplied by the plasma volume $(p=0.0011)$.

When correlating the variables plasma enzym activity, cumulative leakage and muscle damage, respectively, with achievement, SII, HII, decrease in performance, urea, cortisol, testosterone and DHEAS, the values of $r$ are larger when correlating muscle damage with the other variables than when correlating cumulative leakage with the other variables and these are again larger than when correlating plasma activity with the other variables. The results from histology (Chapter 5.2) and the CK cumulative activity confirm the amount of damaged muscle. An increase of histological changes in muscle tissue was correlated with the contest distance, but the percentages of changes are too small to get a statistically significant relationship between histological changes and the increase in CK activity.

\section{Content of muscle tissue}

Apple et al. (1) described that the CK activity in muscle tissue of males was a factor $\mathbf{1 . 6}$ higher than in females. In our study we cannot confirm these findings. Due to the training between the 15 and $42 \mathrm{~km}$ contest there was neither an increase of muscle tissue activity nor a gender difference. Our findings may be strengthened by the following observations. First there was no difference found in substrate creatinphosphate (CP) in muscle tissue (Chapter 5.1). Secondly no difference in plasma activity of $\mathrm{CK}$ was found between males and females before each contest. Thirdly after the 15 and 25 $\mathrm{km}$ contests no difference was found In CK cumulative activity. 
Summarizing we may conclude that minor muscle damage occurred after physical stress, but that no direct relationship was observed between histological features and enzyme leakage.

it is remarkable that in contrast to the findings after the 15 and $42 \mathrm{~km}$ contests no significant relationship was found between plasma activities of Asat and CK with the variables SIl, performance time, performance decrease $\left(T_{2} \cdot T_{1}{ }^{-1}\right)$, urea and the concentrations of the chosen hormones after the $25 \mathrm{~km}$ contest. A possible reason is training adaptation. This suggests that the physical stress tolerance increased more than the physicall stress in the training period between the 15 and $25 \mathrm{~km}$ contest.

In relationship to the training status of the subjects who ran 15 , 25 and $42 \mathrm{~km}$ contests and the ratio between physical stress and physical stress tolerance more research has to be carrled out to solve the question as to which is the primary factor to increase the plasma activity of muscle enzymes or muscle damage (21). However, the advice to take rest for recovery in order to regain the balance between physical stress and physical stress tolerance remains very important for every recreational and elite male and female runner.

\section{Meferences}

1 Apple F.S.; Rogers M.A., Casal D.C., Lewis L., Ivy J.L., and Lampe J.W.: Skeletal muscle creatine kinase MB alterations in women marathon runners. Eur J Appl Physiol 56:49-52,1987.

2 Apple F.S., Rogers M.A., Casal D.C., Sherman W.M., and Ivy J.L.: Creatine kinase-MB Isoenenzyme adaptations in stressed human skeletal muscle of marathon runners. J Appl Physiol 59(1):149-153,1985.

3 Berg A., Haralamble G.: Changes in serum creatine kinase and hexose phosphate isomerase activity with exercise duration. Eur J Appl Physiol 39:191-201,1978.

4 Berg A., Keul J.: Muscular enzyme activities in relation to maximum aeroblc capacity in healthy male adults. Aust $\mathbf{J}$ Sp Med 13(4):87-92,1981.

5 Berg A., Keul J.: Serum enzyme kinetics during and after intensive long term stress. Disch Zelt Sportmed 1:12-17, 1982.

6 Berg A., KIm S.S., Keul J.: Skeletal muscle enzyme actlvities in healthy young subjects. Int $J$ Sports Med. 7:236-239, 1986.

7 Clarkson P.M., Byrnes W.C., Gillsson E., and Harper E.: Adaptation to exerclse-Induced muscle damaged. Clin Sci 73: 383-386, 1987.

8 Bergmeler C.K.,Bücher Th., Luh W., Pette P.: Elntache und zusammengesetze optische Test mit pyridin nucleotiden in: Lang K., and Lehnartz E. (ed). Hoppe-Seyler, Thlerselder Handbuch der Physlologlsch- , Pathologisch- ChemischeAnalyse für Artz, Blologen und Chemiker. 6A (10 the edition) Springer-Verlag, Berlin 1964, pp 292-339.

9 Clarkson P.M., Kroll W., Graves $J_{\text {., }}$ and Record W.A.: The relationship of serum creatine kinase, fiber type, and Isometric exercise. Int Sports Med 3:145-148,1982. 
10 Diamond Th., Smith R, Goldman A.D., and Myburgh D.D.M.: The dilemma of the creatine kinase (CK-MB) in marathon runners. S Afr Med J 63:37-41,1983.

11 Glatz J.F.C., Turner P.R.., Katan M.B., Stalenhoef A.F.H., Lewis $B_{\text {. }}$ : Human hypo- and hyperresponders to dietary cholesterol differ in the responsiveness of their low density lipoprotein production. Arteriosclerosis, submitted.

12 Friedel, R., Mattenheimer $H_{\text {.: }}$ The feigned release of cell enzymes, distribution and transport of cell enzymes within the extra cellular space. $J$ Clin Chem Clin Blochem 14:109$117,1976$.

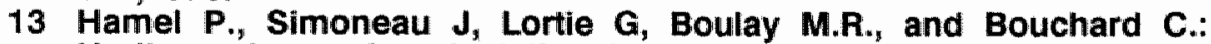
Herity and muscle adaptation to endurance training. Med Sci Sport Exer 18(6):690-696,1986.

14 Haralambie G., Berg A.: Creatine kinase and hexose phosphate isomerase activity in skeletal muscle of healthy male adults. Enzyme 23:104-107, 1978.

15 Hermens W.Th., Willems G.M., Davids H.A.: Enzymatic assesment of myocardial injury after infarction or cardiac surgery. Is isoenzyme analysis necessary? Clin Chim Acta 156:235-246,1986

16 Janssen G.M.E., Kuipers H., Keizer H.: Plasma CPK and AST activity, and plasma testosterone after $200 \mathrm{~km}$ speed skating. Med Sci Sports Exerc 18 (suppl):205,1986.

17 Janssen G.M.E., Kuipers H., Keizer H.A., Geurten P., Kranenburg van G., and Does R.J.M.M.: Spierbeschadiging, prestatievermogen en herstel na verschillende soorten wegwedstrijden. Gen en Sport 20(5):190-195,1987.

18 Janssen G.M.E., Kuipers H., Verstappen F., Keizer H.: Muscle damage and recovery after a marathon compared to a $25 \mathrm{~km}$ race (abstract). Med Sci Sports Exerc 16:200,1984.

19 Janssen G.M.E., Kuipers H., Kelzer H., Verstappen F.: Plasma enzyme activities and running performance in a maximal treadmill test before and after a $30 \mathrm{~km}$ race or a marathon. Int J Sports Med 5(suppl):98-99,1984.

20 Kaman R.L.: The effects of exercise on serum enzymes. Osteopath Ann 5:442-448,1977.

21 Noakes T.D.: Effect of exercise on serum enzyme activities in humans. (a review) Sports Med 4:245-267,1987.

22 Noakes T.D., Carter J.W.: The responses of plasma biochemical parameters to a $56-\mathrm{km}$ race in novice and experienced ultra-marathon runners. Eur $J$ Appl Physiol 49:179-186,1982.

23 Noakes T.D., Kotzenberg G.: Elevated serum creatine kinase MB and creatine kinase BB isoenzyme fractions after ultramarathon running. Eur J Appl Physiol 52(1):75-79,1983.

24 Norregaard-Hansen K., Bjerre-Knudsen J., Brodthage $U_{\text {., Jordal }}$ R., Pauko P.E.: Muscle cell activity due to long distance training. Eur J Appl Physiol 48:177-188,1982.

25 Rogers M.A., Stull G.A., and Apple F.S.: Creatine kInase isoenzyme activities in men and women following a marathon race. Med Scil Sport Exer 17(6):679-682,1985.

26 Raimondi G.A., Puy R.J.M., Raimondi C.A., Schwarz E.R. and Rosenberg M.: Effects of physical training on enzymatic activity of human skeletal muscle. Biomedicine 22:496-501,1975. 
27 Rose, L.I.: Serum enzymes after marathon running. J Appl Physiol. 29(3)2:355-357,1970.

28 Schnohr $P_{*}$, Grande $P_{*}$, and Christiansen $C$ :: Enzyme activities in serum after extensive exercise, with special reference to creatine kinase MB. Acta Med Scand 208:229-231,1980.

29 Shapiro Y., Magazanik A., Sohar E., Relch C.B.: Serum enzyme changes in untrained subjects following a prolonged march. Can J Physilol Pharmacol 51:271-276,1973.

30 Sherman W.M., Costill D.L., Fink W.J.: Effect of a $42.2 \mathrm{~km}$ footrace and subsequent rest or exercise on muscle and enzymes. J Appl Physiol 55(4):1219-1224,1983.

31 Siegel A.d., Silverman L.M., Lopez R.E.: Creatine kinase elevations in marthon runners: relationship to training and competion. Yale $J$ Biol Med 53:275-279,1980.

32 Shumate J.B., Brooke M.H., Carroll J.E. and Davis J.E.: Increased serum creatine kinase after exercise: A sex-linked phenomenon. Neurology 29:902-904,1979.

33 Siest, G., Galseau M.M.: Variations of plasmatic enzymes during exercise. Enzyme 17:179-195,1974.

34 Sjödin B., Svedenhag J.: Applied physilogy of marathon running. Sports Med (review article) 2:83-99,1985.

35 Suominen $H_{\text {. }}$, Heikkinen $E_{\text {. }}$ : Enzyme activities in muscle and connective tissue of $M$. vastus lateralis in habitually training and sedentary 33 to 70 -year-old men. Eur $J$ Appl Physiol 34:249-254,1975.

36 Szasz G., Gruber W., Bernt E.: Creatine kinase in serum: 1. Determination of optimum reaction conditions. Clin Chem 22(5):650-656,1976.

37 Tsung S.H.: Creatine kinase isoenzyme patterns in human tissue obtained at surgery. Clin Chem 22(2):173-175,1975.

38 Willems G.M., Muljtjens A.M.M., Lambi F.H.H., Hermens W.Th. Estimation of cilrculatory parameters in patients with acute myocardial infarction. Significance for calculation of enzymatic infarct size. Cardiovasc Res 13:578-587,1979.

39 Willems G.M., Visser M.D., Krill M.T.A., Hermens W.Th.: Quantitative analysis of plasma enzyme levels based upon simultaneous determination of different enzymes. Cardiovasc Res 16:120-131,1982.

40 Willems G.M., Veen van der F.H., Huysmans H.A.: Enzyma tic assesment of myocardial necrosis after cardiacsurgery: Differentiation from skeletal muscle damaged, hemolysis, and IIver injury. Am Heart J 109:1243-1252,1985.

41 Wolf P.L., Lott J.A., Nitti G.J. Bookstein R.: Changes in serum enzymes, lactate, and haptoglobin following acute physical stress in international-class athletes. Clin Biochem 20:73-77, 1987 .

42 Wyndham C.H.: Heat stroke and hyperthermia in marathon runners. Ann $N$ Y Ac Sc 301:128-138,1977. 
Chapter 6 Hematological changes associated with training for a marathon

6.1 The effect of training on red blood cell parameters and plasma ferritin: a transverse and a longitudinal approach.

\section{Introduction}

In recent years there has been a growing interest in long distance running and especially in marathon running. Next to the health promoting effect (prevention of cardiovascular diseases) there are some risks attributable to the amount of physical exercise in intensively training long distance runners. For instance, the number of running injuries is still growing. Long distance runners tend to have hemoglobin values at the lower end of the normal range or below. The prevalence of anemia in athletes has been well described in literature $(6,14,15,22,24,43,45,46)$. In sport medicine this lower hemoglobin value has been called sport anemia and suboptimal hemoglobin concentration.

Criterla for sport anemia are:

females: $\mathrm{Hb}<7.4$ mmol. $\mathrm{I}^{-1}$, males: $\mathrm{Hb}<8.7 \mathrm{mmol.1-1}$

Criteria for suboptimal hemoglobin:

females: $\mathrm{Hb}<8.7 \mathrm{mmol.} \mathrm{I}^{-1}$, males: $\mathrm{Hb}<10$ mmol. $\mathrm{I}^{-1}$

The concept of suboptimal hemoglobin values has been chosen regarding the theory that higher hemoglobin values will be needed for a maximal performance in athletes (31).

An increase of the concentration of hemoglobin by reinfusion of autologous erythrocytes has been demonstrated to result in an improved aerobic capacity in well trained athletes. This tends to support the theory mentloned before $(5,40)$.

The mechanism of the lower hemoglobin level in athletes is still a matter of debate. Three hypotheses have been proposed to explain this sport anemia $(8,20,24,28,32)$.

1. The anemia may be a result of the physiologic adaptation to endurance exercise. The oxygenisation of the tissues is enhanced by a decreased viscosity of the blood as a result of a plasma volume expansion. This increased plasma volume leads to lower hematocrit values. The total amount of circulating hemoglobin does not change or is even greater. This is a situation comparable to the lower hemoglobin levels in pregnancy $(6,27,35)$.

2. The anemia may be a result of an increased Intravasal destruction of red cells due to mechanical impact In the footsole during running. This problem has been solved by wearing shoes with a great capacity of shock absorption $(16,17,23)$.

3. The anemia is a result of iron deficlency due to decreased Iron absorption or increased Iron loss $(9,15,16,18,25,42,43)$. 
This last hypothesis is supported by several authors in sport medicine. Comparison of these different investigations is difficult because of the great difference in methods used to assess the iron status of the participating athletes. Parameters mostly used are: hemoglobin $(\mathrm{Hb})$, hematocrit $(\mathrm{Ht})$, mean corpuscular volume (MCV), mean corpuscular hemoglobin $(\mathbf{M C H})$, mean corpuscular hemoglobin content (MCHC), erythrocyte count, plasma ferritin, serum iron and iron binding capacity. Moreover, Magnussen determined the iron content of the bone marrow (28).

Latent or manifest iron deficiency in athletes can be attributed to:

- Insufficient content of iron in nutrition (quantitatively and qualitatively) $(10,21)$.

Clement et al. (7) demonstrated an average iron intake of 0.22 mmol iron in daily food in females and of $0.33 \mathrm{mmol}$ in males. The Recommended Daily Allowance (RDA) of iron in females ils $0.25 \mathrm{mmol}$. The iron deficliency could be a result of suboptimal iron stores.

- Decreased absorption of iron from the gut. In contrast with iron deficient non-exercising females, the absorption of iron in female athletes has been demonstrated to be much less. Thils has been ascribed to the composition of the food $(21,30)$.

- Increased iron loss.

- Several ways of blood-loss can contribute to an increased iron loss. Blood donation exerts a great demand on total body iron stores. The majority of body iron is incorporated in hemoglobin. A single blood donation of $500 \mathrm{ml}$ results in a loss of $4.48 \mathrm{mmol}$ iron from the total body iron stores (29).

- Hematuria in long distance runners can result in iron loss. This could be explained by microtraumata of the bladder (23). - Hemoglobinuria has often been found in long distance runners. Increased intravasal destruction of erythrocytes leads to a saturation of the hemoglobin-haptoglobin complex. Free circulating hemoglobin is then excreted by the kidneys. Wearing good running shoes reduced this way of iron loss (18). - Occult blood loss from the gut has recently been demonstrated in athletes after running a marathon. With a semi-quantitative method an iron loss of 3.6 to $36 \mu$ mol could be demonstrated in intensively training athletes. The excessive use of analgetic drugs could be an explanation of an increased iron loss $(36,38)$. - During exerclise sweat contains up to $5.2 \mu \mathrm{mol} . \mathrm{I}^{-1}$ iron in male athletes. In a daily long distance training with a loss of perspiration 2-3 I, one can lose up to $1 \mathrm{mg}$ (18umol) iron a day. Other investigators demonstrated a great difference in the amount of Iron excretion in sweat during exercise. The problem in comparing the results is the great difference in sampling methods. Kaiser et al. found an iron excretion in males of $5.11 \pm 0.65 \mu \mathrm{mol} . \mathrm{I}^{-t}$ but demonstrated a significant lower iron excretion $(p<0.01)$ in females of $3.05 \pm 0.46 \mu$ mol $\|^{-1}(26,33,41)$. 
In this study a group of untrained people embarking on long distance running were followed during a period of $18-20$ months training. For reasons of health monitoring we did repeated blood tests in order to detect a developing anemia. Moreover we looked for possible changes in red blood cell parameters in intensively training athletes. To follow the iron status we measured plasma ferritin (29).

Next to the usual transverse approach of the results, the results will be presented in a longitudinal approach using the intraindividual variability. These results will be compared to the results of a reference group $(1,12)$.

\section{Materials and methods}

\section{Subjects}

A group of 83 males and 31 females were chosen non-selectively from more than 500 responders to the questionnaire. The participants were untrained and their age was at least 21 years. Sixty males and 18 females completed the study. At the beginning of this study the participants had a medical check-up, in which pre-values of the hematologicall parameters were determined.

During the study which took 18-20 months, there were three contests of 15, 25 and $42 \mathrm{~km}$. Six samples of 3-4 ml (Chapter 2; p. 22) were taken (1 week before and 1 week after the contests), as deplcted in Fig. 6.1.1.

The delay between taking samples and the determining of the variables was $3-4 \mathrm{~h}$ at $4 \circ \mathrm{C}$ and $1-2 \mathrm{~h}$ at $18-20 \circ \mathrm{C}$. The variables were determined in one run.

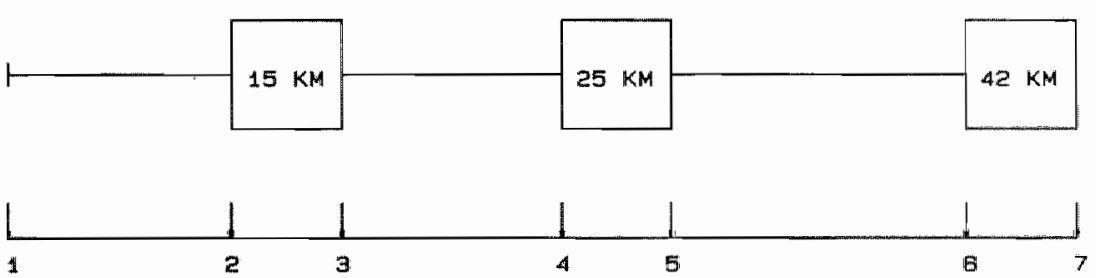

Fig. 6.1.1 Time schedule of the protocol during the tralning period with speclail reference to the moments of blood sampling for hematologlcal varlables.

Using this design the changes of hematological parameters can be studied transversely and longitudinally.

For reasons of health subjects with ferritin levels lower than

$20 \mu \mathrm{g} . \mathrm{I}^{-1}$ were supplemented orally with iron (dally dosis $2-3 \mathrm{mmol}$ ) for six weeks (Table 6.1.3). The number of supplemented subjects increased from 4 females and 1 male in the beginning to 12 females in the final training period. 


\section{Laboratory parameters}

The hematological parameters determined in blood samples 1 to 7 were: hemoglobin (mmol. $\left.\right|^{-1}$ ), hematocrit $\left(1 .\left.\right|^{-1}\right)$, erythrocyte count (T.I-1), mean cell volume (MCV;fl), mean cell hemoglobin (MCH; fmol), mean cellular hemoglobin content (MCHC;mmol. ${ }^{-1}$ ) and red cell distribution width (RDW; \%). RDW is defined as the ratio of the width of the frequency distribution curve at half-high of the maximum of the distribution curve divided by the corresponding erythrocyte volume multiplied with $100 \%$.

Ferritin has been proved to be a good parameter to detect an iron deficiency. There are very few false negatives using ferritin as a parameter for total body iron stores. False positives can be produced by some chronic diseases because ferritin reacts as an acute-phase protein. The stress of a running contest could mask a possible iron deficiency state. Regarding the short half-life time of ferritin, this will not interfere with our investigation (11).

\section{Statistical analysis}

In the transverse approach the results are given as means and standard deviations. In order to determine the significance of differences of the parameters in the course of the training period a nonparametric (two-way) ranking test of Wilcoxon was used. The values of ferritin content (samples 1 to 7 ) are described with boxand-whilsker plots (Fig. 6.1.2). Gender differences were tested with the Mann-Whitney method.

In the longitudinal approach the intra-individual variability of the parameters was calculated and expressed as ( $\mathrm{N}_{\text {var }}$ and $\mathrm{CV}_{\mathrm{poo}}$ ). Nuar was obtained by calculating the percentage of Individuals for which the total variance was greater than the analytical variance (or equivalently the total CV was greater than the analytical CV).

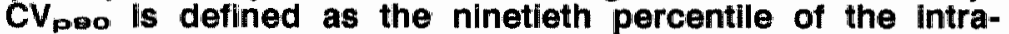
individual variation coefficient (Chapter 2 ; p. 39).

The long-term coefficients of analytical variance of the variables have been described in Chapter 2; p. 34.

\section{Results}

\section{Transverse approach}

The means and the standard devlations of the transverse values are depicted in Table 6.1.1 and Table 6.1.3. The statistical signiflcances are presented in Table 6.1.2 and Table 6.1.4.

\section{Erythrocytes, hemoglobin and hematocrit}

Durlng the three training perilods the erythrocyte counts decreased in males from $5.03 \pm 0.29 \mathrm{~T}$ T.I-T (sample 1) to $4.91 \pm 0.25 \mathrm{~T} . \mathrm{It}^{-1}$ (sample 6) $\left(p<0.001\right.$ ), but did not change in females from $4.43 \pm 0.33 \mathrm{~T}^{-1}$ (sample 1) to $4.41 \pm 0.32 \mathrm{~T} .1-1$ (sample 6$)(p>0.1)$.

The hemoglobin content decreased only in males from $9.53 \pm 0.50$ mmol. $\left.\right|^{-1}$ to $9.30 \pm 0.47 \mathrm{mmol}^{-1}(p=0.001)$. In sample $66.7 \%$ of the male volunteers had a hemoglobin content lower than 8.5 mmol..1-1. 
Table 6.1.1 Hematologlcal varlables (erythrocytes and ferrltin) in males before and after the 15,25 and $42 \mathrm{~km}$ contests

\begin{tabular}{|c|c|c|c|c|c|c|c|}
\hline & Start & 15 & $m$ & 25 & & 42 & $\mathrm{~m}$ \\
\hline & 1 & $\begin{array}{c}\text { before } \\
2\end{array}$ & $\begin{array}{c}\text { after } \\
3\end{array}$ & $\begin{array}{c}\text { before } \\
4\end{array}$ & $\begin{array}{c}\text { after } \\
5\end{array}$ & $\begin{array}{c}\text { before } \\
16\end{array}$ & $\begin{array}{c}\text { after } \\
7\end{array}$ \\
\hline $\begin{array}{l}\text { Ery } \\
\text { mean }\end{array}$ & 5.03 & 5.01 & 4.88 & 4.86 & 4.91 & 4.91 & 4.72 \\
\hline $\begin{array}{c}\mathrm{sd} \\
\mathrm{Hb}\end{array}$ & 0.29 & 0.27 & 0.28 & 0.27 & 0.29 & 0.25 & 0.28 \\
\hline $\begin{array}{l}\text { mean } \\
\text { sd }\end{array}$ & $\begin{array}{l}9.53 \\
0.50\end{array}$ & $\begin{array}{l}9.30 \\
0.47\end{array}$ & $\begin{array}{l}9.13 \\
0.49\end{array}$ & $\begin{array}{l}9.22 \\
0.48\end{array}$ & $\begin{array}{l}9.24 \\
0.55\end{array}$ & $\begin{array}{l}9.30 \\
0.47\end{array}$ & $\begin{array}{l}9.03 \\
0.52\end{array}$ \\
\hline $\mathrm{Ht}$ & & & & & & & \\
\hline $\begin{array}{l}\text { mean } \\
\text { sd }\end{array}$ & $\begin{array}{r}46 \\
2\end{array}$ & $\begin{array}{r}45 \\
2\end{array}$ & $\begin{array}{r}44 \\
2\end{array}$ & $\begin{array}{r}44 \\
2\end{array}$ & $\begin{array}{r}45 \\
3\end{array}$ & $\begin{array}{r}44 \\
2\end{array}$ & $\begin{array}{r}43 \\
3\end{array}$ \\
\hline $\mathbb{M C V}$ & & & & & & & \\
\hline $\begin{array}{l}\text { mean } \\
\text { sd }\end{array}$ & $\begin{array}{r}91.6 \\
2.8\end{array}$ & $\begin{array}{r}90.0 \\
2.6\end{array}$ & $\begin{array}{r}90.0 \\
2.5\end{array}$ & $\begin{array}{r}91.5 \\
2.8\end{array}$ & $\begin{array}{r}91.5 \\
2.8\end{array}$ & $\begin{array}{r}90.7 \\
2.4\end{array}$ & $\begin{array}{r}90.6 \\
3.2\end{array}$ \\
\hline $\mathrm{MCH}$ & & & & & & & \\
\hline meani & 1.90 & 1.86 & 1.87 & 1.90 & 1.88 & 1.90 & $1.9 \|$ \\
\hline $\begin{array}{l}\text { Sd } \\
\text { MOHC }\end{array}$ & 0.08 & 0.08 & 0.07 & 0.09 & 0.07 & 0.06 & 0.07 \\
\hline $\begin{array}{l}\text { mean } \\
\text { sd }\end{array}$ & $\begin{array}{r}20.7 \\
0.4\end{array}$ & $\begin{array}{r}20.6 \\
0.5\end{array}$ & $\begin{array}{r}20.8 \\
0.5\end{array}$ & $\begin{array}{r}20.7 \\
0.6\end{array}$ & $\begin{array}{r}20.6 \\
0.4\end{array}$ & $\begin{array}{r}20.9 \\
0.3\end{array}$ & $\begin{array}{r}21.1 \\
0.6\end{array}$ \\
\hline RDW & & & & & & & \\
\hline mean & 15.3 & 14.8 & 14.8 & 14.4 & 14.1 & 16.5 & 16.4 \\
\hline sod & 2.2 & 0.6 & 0.6 & 1.0 & 1.1 & 0.7 & 0.7 \\
\hline Fer & & & & & & & \\
\hline $\begin{array}{l}\text { mean } \\
\text { sd }\end{array}$ & $\begin{array}{r}113 \\
68\end{array}$ & $\begin{array}{l}96 \\
56\end{array}$ & $\begin{array}{l}92 \\
60\end{array}$ & $\begin{array}{l}97 \\
59\end{array}$ & $\begin{array}{l}96 \\
62\end{array}$ & $\begin{array}{r}103 \\
63\end{array}$ & $\begin{array}{l}88 \\
55\end{array}$ \\
\hline & & 30 & 00 & 59 & 02 & 00 & 30 \\
\hline
\end{tabular}

Mean values \pm sd ; Erythrocyte count (Ery; T.. $I^{-1}$ ), hemoglabin concentration (Hb; mol. $1^{-1}$, hematocrlt (Ht; $1.1^{-1}$ ), mean cell volume (MCV; $f H$ ), mean cell hemoglobin (MCV; fmol), mean cellular hemoglobin content (MCHC; mol. ${ }^{-1}$ ), red cell distirlbution width ( $R D W ; \%$ ) and Ferr It In content (Fer; $\mu \mathrm{g} . \mathrm{I}^{-1}$ ).

Table 6.1.2 Results of Wilcoxon tests (two-way) concerning erythrocyte count, the erythrocytlo parameters and ferritin in males

\begin{tabular}{lccccccccc}
\hline Sample 2/1 & $4 / 1$ & $6 / 1$ & $3 / 2$ & $5 / 4$ & $7 / 6$ & $2 / 4$ & $2 / 6$ & $4 / 6$ \\
\hline Ery ns & $<0.001$ & 0.002 & 0.001 & ns & $<0.001$ & 0.004 & ns & $<0.001$ \\
Hb $<0.001$ & $<0.001$ & 0.001 & 0.008 & ns & $<0.001$ & $n . s$. & ns & 0.003 \\
Ht 0.002 & $<0.001$ & 0.001 & 0.001 & ns & 0.001 & 0.003 & ns & 0.001 \\
MCV $<0.001$ & ns & 0.001 & ns & ns & ns & ns & ns & ns \\
MCH $<0.001$ & ns & ns & ns & ns & 0.001 & 0.014 & ns & 0.001 \\
MCHC ns & ins & 0.018 & ns & 0.040 & 0.024 & 0.011 & ns & 0.004 \\
RDW $<0.001$ & $<0.001$ & $<0.001$ & ns & $<0.001$ & ns & 0.008 & ns & 0.025 \\
Fer $<0.001$ & 0.001 & ns & ns & ns & 0.013 & ns & ns & ns
\end{tabular}

See for explanatlons legend of Table 6.1.1 
Table 6.1.3 Hematologlcal varlables (erythrocytes and ferrlitin) In females before and after the 15,25 and $42 \mathrm{~km}$ contests

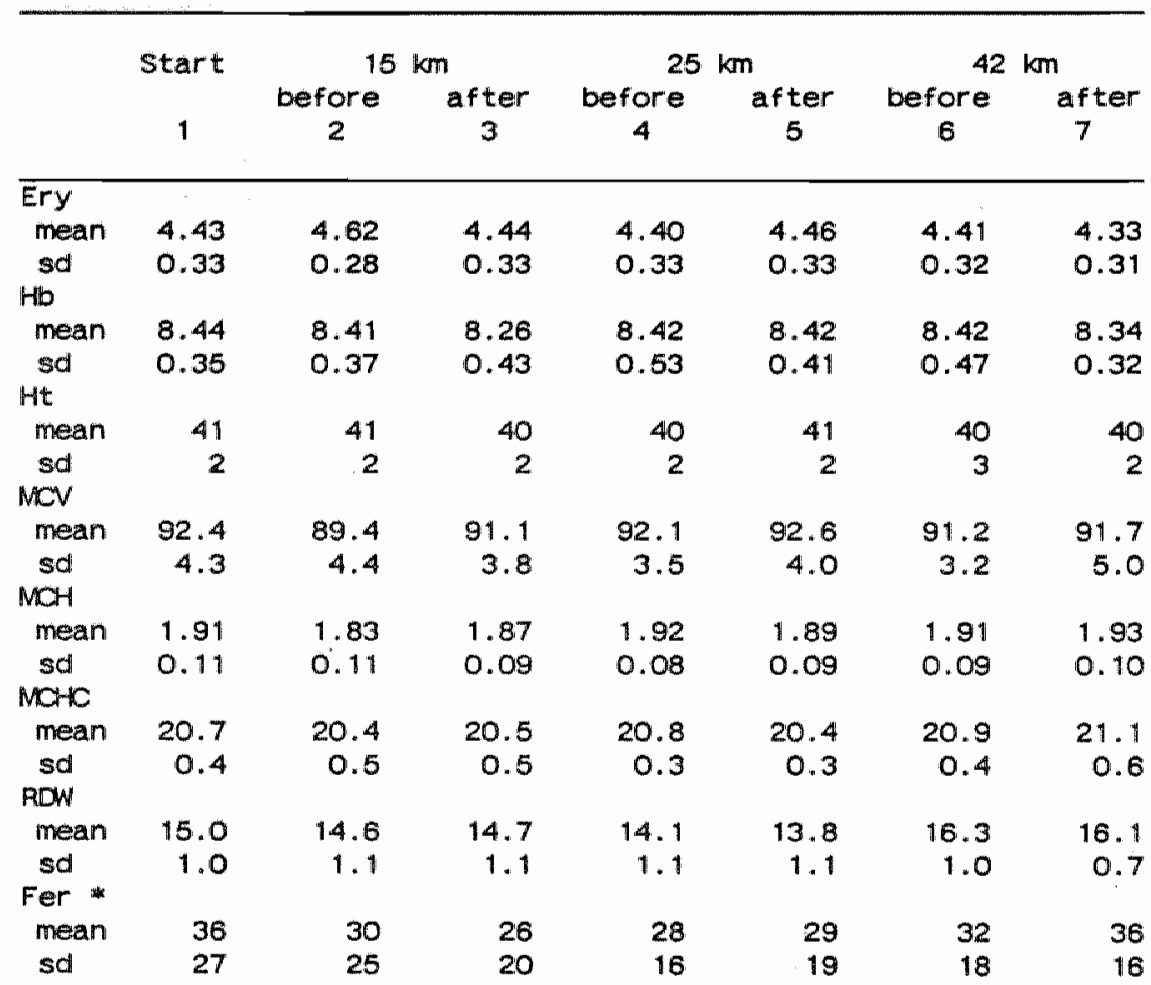

See for explanatlons legend of Table 6.1.1

* represents supplementation orally with 1 ron (dally dosis 2-3 nmol)

Table 6.1.4 WIlcoxon tests concerning erythrocyte count, the erythrocytlc parameters and ferritin (two-way) in females.

\begin{tabular}{llllllllll}
\hline Sample $2 / 1$ & $4 / 1$ & $6 / 1$ & $3 / 2$ & $5 / 4$ & $7 / 6$ & $2 / 4$ & $2 / 6$ & $4 / 6$ \\
\hline Fer & 0.008 & ns & ns & ns & ns & ns & ns & 0.008 & ns \\
Ery & 0.022 & ns & ns & 0.028 & ns & ns & 0.025 & ns & ns \\
Hb & ns & ns & ns & ns & ns & ns & ns & ns & ns \\
Ht & ns & ns & ns & ns & ns & ns & ns & ns & ns \\
MCV & 0.002 & ns & 0.016 & ns & ns & ns & ns & ns & ns \\
MCH 0.002 & ns & ns & n.s & 0.028 & ns & 0.021 & ns & 0.041 \\
MOHC ns & ns & 0.025 & ns & 0.001 & ns & 0.007 & ns & ns \\
ROW 0.016 & 0.005 & 0.001 & ns & 0.029 & ns & 0.023 & ns & ns
\end{tabular}

See for explanations legend of Table 6.1.1 
In females the hemoglobin content did not change (sample 1: $8.44 \pm 0.35 \mathrm{mmol} . \mathrm{I}^{-1}$ and sample $\left.6: 8.42 \pm 0.47 \mathrm{mmol}^{-1} \mathrm{l}^{-1}\right)$. The hematocrit decreased significantly only in males (sample 1: $0.46 \pm 0.02$ I.1-1 $^{-1}$ and sample 6: $0.44 \pm 0.02$ i.1-1; $p<0.001$ ).

$\mathrm{MCV}, \mathrm{MCH}, \mathrm{MCHC}$ and $\mathrm{RDW}$

During the first period of training (sample 1 to 2 ) the values of MCV decreased in males from $91.6 \pm 2.8 \mathrm{fl}$ to $90.0 \pm 2.6 \mathrm{fl} \quad(p<0.001)$ and in females from $92.4 \pm 4.3 \mathrm{fl}$ to $91.1 \pm 3.8 \mathrm{fl}(\mathrm{p}=0.002)$. In the second period MCV increased back to the level of sample 1 in males and females. The MCV values stayed nearly at a similar level in the last period both in malles and females. There were no significant changes between the MCV values before and after the contests in males and females.

The values of $\mathrm{MCH}$ decreased in the first period in males (sample 1: $1.90 \pm 0.08 \mathrm{fmol}$ and sample 2: $1.86 \pm 0.08$ fmol with $p<0.001)$ and in females sample 1: $1.91 \pm 0.11 \mathrm{fmol}$ and sample 2: $1.83 \pm 0.11 \mathrm{fmol}$ with $p=0.002$ ) and returned to the starting values in the course of the other two training periods.

The $\mathrm{MCHC}$ increased during the last period (sample 1 to 6 ) in males $(p=0.018)$ and fernales $(p=0.025)$ from $20.7 \pm 0.4 \mathrm{mmol}^{-1}$ to $20.9 \pm 0.3$ mmol.t-1 and from $20.7 \pm 0.4 \mathrm{mmol}^{-\mathrm{I}^{-1}}$ to $21.0 \pm 0.4 \mathrm{mmol} . \mathrm{I}^{-1}$ respectively.

The RDW decreased significantly and continuously in the first two training periods both in males and in females and increased significantly in both groups during the last period of training (Table 6.1.2 and Table 6.1.4).

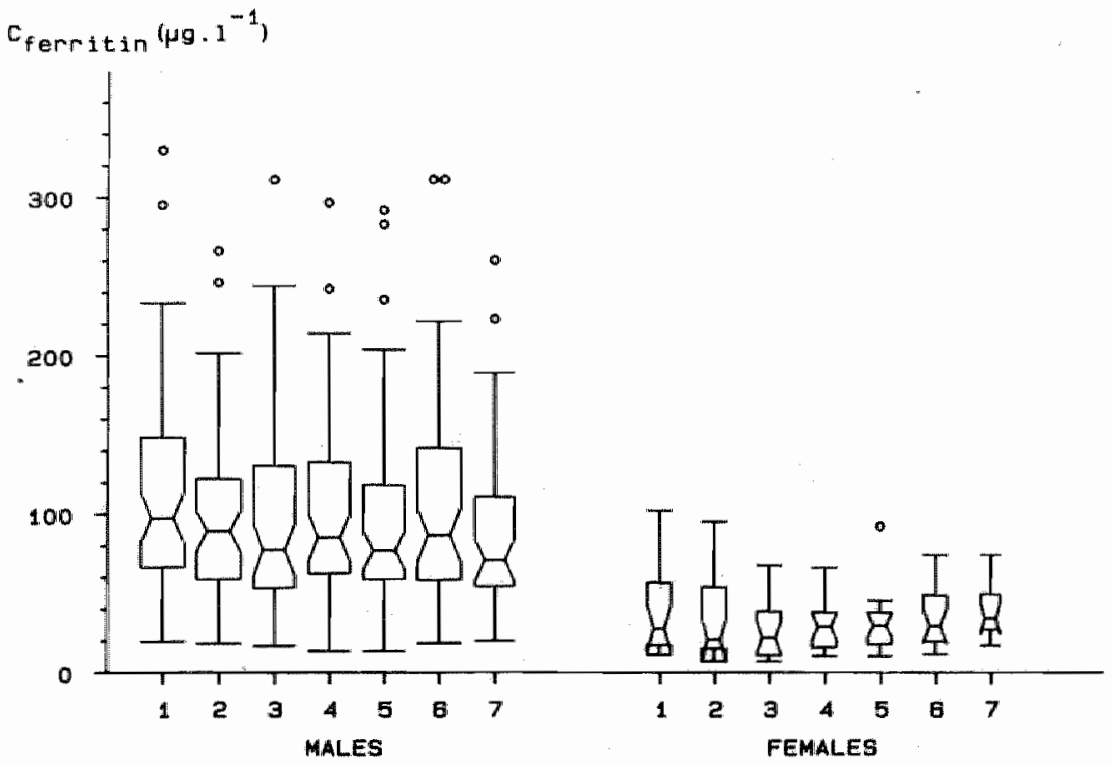

FIg. 6.1.2 Box-and-whlsker plots of ferrltin content $\left(\mu g .1^{-1}\right)$ during the training perlod (start, before and after each contest). 
Ferritin

The ferritin content decreased in the first period of training (sample 1 to 2) in males from $113 \pm 68 \mu \mathrm{g.l-1}$ to $96 \pm 56 \mu \mathrm{g.l}-1$ $(p<0.001)$ and in females from $36 \pm 27 \mu \mathrm{g} .1-7$ to $30 \pm 25 \mu \mathrm{g} .1-1 \quad(p<0.01)$ (Fig. 6.1.2). In the course of the other two training periods there was no significant change in males (Table 6.1.1 and Table 6.1.2). In the females the ferritin content increased significantly $(p=0.008)$ during the last two training periods. The percentage of the volunteers with a lower ferritin content of $20 \mu \mathrm{g} . \mathrm{I}^{-1}$ in the samples $1,2,4$ and 6 was in females $27.8 \%$ (5 pp), $55.6 \%(10$ pp), $38.9 \%$ (7 pp) and $27.8 \%(5 \mathrm{pp})$ respectively and in males $1.6 \%$ in sample 1 (1 pp).

\section{Longitudinal approach}

The results of the data analysis are presented in Table 6.1.5.

The erythrocyte count varied very much both in males and females ( $N_{\text {var }}$ was $98 \%$ and $94 \%$ respectively) and also the intra-individual variation ( $\left.\mathrm{CV}_{\mathrm{p} \text { oo }}\right)$ was higher than in the study of Bas ot al. $\left(C_{\text {poo }} 21.7 \%\right.$ and $\left.32.0 \%\right)$, which we used as reterence (1).

Table 6.1.5 Nar and $\mathrm{CV}_{\mathrm{p} 90}$ : comparison of males and females for the red cell system dur Ing the course of the study

\begin{tabular}{|c|c|c|c|c|c|c|}
\hline & Nvar & Nvar & Mvar & $C V_{p 90}$ & $C V_{p 90}$ & $C V_{p 90}$ \\
\hline & males & females & ref & males & females & ref \\
\hline Ery & 98 & 94 & 57 & 21.7 & 32.0 & 5.0 \\
\hline $\mathrm{Hb}$ & 47 & 44 & 41 & 4.1 & 4.2 & 4.2 \\
\hline $\mathrm{Ht}$ & 92 & 94 & 34 & 6.2 & 6,5 & 3.4 \\
\hline $\mathrm{MCV}$ & 53 & 72 & nat & 2.0 & 2.4 & nd \\
\hline $\mathrm{MOH}$ & 7 & 17 & nd & 0.0 & 2.6 & nd \\
\hline MOHC & 3 & 0 & nd & 0.0 & 0.0 & nd \\
\hline RDW & 98 & 94 & 97 & 9.6 & 10.2 & 5.3 \\
\hline Ferr $|t|$ & $n 100$ & 100 & 82 & 41.0 & 66.9 & 37.8 \\
\hline
\end{tabular}

The Hb content varied in number and in amount similarly to the ones in the mentioned study, whlch was used as reference (1) (Nvar/CVpoo, M:47\%/4.1\%, F:44\%/4.2\% and reference values $41 \% / 4.2 \%$ for both sexes).

The $\mathbb{N}_{\text {var }}$ of Ht was very high (males $92 \%$, temales $94 \%$ ) in comparison to that of the reference group $(34 \%)$. The $\mathrm{CV}$ poo of in the present study was about twice the value of the reference group.

The $\mathrm{N}_{\text {ver }}$ of the cell Indices (MCV, MCH and MCHC) in males was smaller than In the other parameters, whereas in females there were larger differences. 
The $N_{v a r}$ of the RDW was similar to the $N_{v a r}$ of the reference group, but the $\mathrm{CV}_{\text {peo }}$ was twice as high as the reference group (M/N: $9.6 \% / 10.2 \%$ and ref.: $5.3 \%$ for both sexes).

Both in males and females the $\mathrm{N}_{\text {var }}$ of $\mathrm{RDW}$ values $(100 \%)$ were higher than the reference group $(82 \%)$. The $\mathrm{CV}_{\mathrm{p} \text { oo }}$ of the RDW was higher in this study than in the study of Costongs et al. and the

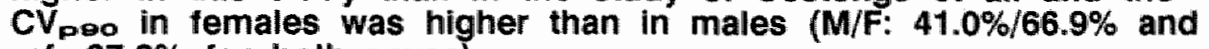
ref. $37.8 \%$ for both sexes).

\section{Discussion}

\section{Transverse approach}

\section{Hematologic parameters}

From the results it can be seen that with increasing training load as described before, the erythrocyte count, the hemoglobin levell and the hematocrit tend to decrease. The MCHC showed a substantial increase in the pre-marathon period. An increase of MCHC has been demonstrated in patients with chronlc infections and rheumatic diseases as a result of shrinking of the erythrocytes (2). This led to a decrease in the hematocrit values. The great increase of the RDW before and after the marathon after a gradual decrease from the start of the training can be attributed to the method of determination which fixates the erythrocytes after being made spherically (3).

During the first part of the study untll the $25 \mathrm{~km}$ contest the RDW decreased which is indicative of the fact that the red cell population was a more homogeneous one than at the start. This may be a positive effect. From the $25 \mathrm{~km}$ contest to the marathon the RDW showed a significant increase which may be a negative effect of the increase of training in the last period. A high ADW can be indicative of an increased mechanical fragmentation of red cells or a decrease of the erythrocytic deformability and osmotic resistance $(3,19)$.

\section{Ferritin}

The most Important finding of this study is the lowering of ferritin values with increasing workload of the training. Both in males and in females there is a considerable decrease in the first perlod. After that a stabilization could be demonstrated and even a slight increase in the last period, although the ferritin levels stayed below the starting values. The slight increase of the ferritln level In females after an initial decrease can be attributed to the iron supplementation they got, when their ferritin level came below the arbitrary critical value of $20 \mu \mathrm{g} \cdot \mathrm{l}^{-1}$ (34).

\section{Longitudinal approach.}

In the longitudinal approach the $\mathrm{N}_{\text {var }}$ and the $C \mathrm{~V}_{\text {poo }}$ were compared to the results of Costongs et al. (12). It has to be taken Into consideration that in their study no differentiation was made between males and females. Remarkable is the large $\mathbf{N}_{\text {var }}$ both in 
males and in females regarding the erythrocyte count and the hematocrit in the present study in contrast to the results of the reference study.

The variability of the hemoglobin concentration is comparable to the variability in the reference population. This may suggest that the regulation of the adaptation to physical stress will be noticed first in the kinetics of the red cells before a change in hemoglobin level will occur. This is also suggested from the minor variability of the $\mathrm{MCH}$ and the $\mathrm{MCHC}$ and the very small $\mathrm{CV}_{\mathrm{poo}}$ for both parameters. The $N_{\text {var }}$ of the RDW in this study is comparable to the

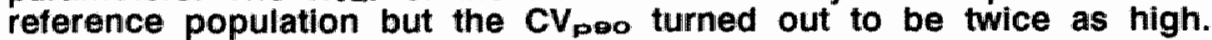
This supports the conclusion of the transverse approach that the RDW has a much higher intra-individual range which can be assessed as a negative effect of the last part of the training before the marathon (37).

An increase of RDW has been demonstrated in patients with artificlal heart valves as a result of mechanical damage and possibly destruction of erythrocytes. Also high RDW and a normal MCV are indicative of an early mixed nutritional Iron (absorption disturbance) deficiency $(2,3)$.

A higher variability and a higher $C_{\text {poo }}$ of the ferritin values were also shown, especially in the females. From this we may conclude that especlally females performing endurance training have to pay special attention to their iron status $(14,18)$.

The discussion on the lower hemoglobin values in athletes is whether this state is pathological or whether it is a physiological adaptation to the exercise done.

The results of this study show a pattern of decrease for the most parameters in the first training period after which there is a stabilization. This decrease is, although significant, clinically not very important and comparable to the results of earlier investigations $(13,32,39)$.

This pattern supports the hypothesis that there is an adaptation in the homeostasis of the body. The large increase in RDW in the last period, however, is remarkable. Together with the corresponding decrease in the MCV and the stable number of erythrocytes these findings suggest that the small erythrocytes increase in number but that the hemoglobin content of these erythrocytes is unchanged (3). Another explanation of the decrease in hemoglobin values has been attributed to the decreased erythropolesis as a result of latent iron deficiency. In endurance athletes latent iron deficiency has been demonstrated several times using ferritin as a parameter $(4,9,15,42)$. In healthy people ferritin has proved to be a good parameter for the measurement of the total body Iron stores. Iron deficlency could be a result of diminished absorption, hematuria, iron loss via perspiration and blood loss in the gut. Magnussen (28) suggested that in athletes ferritin is not the Ideal parameter to assess the iron status. An Increased Intravasal destruction of erythrocytes would saturate the haptoglobinhemoglobin complex which is removed by the hepatocytes. The retlculo-endothelial-system (RES) has a diminished amount of erythrocytes to remove from the circulation and ferritin will not be 
incorporated in the RES. Ferritin measured under this condition would not be representative for the total body iron stores (28). The decrease of RDW and MCV in the first period tends to support this theory. An iron deficiency anemia is not to be expected regarding the stability of the hemoglobin and hematocrit levels in the last two periods before the marathon.

In the present study we demonstrated a significant decrease in ferritin levels (Tables 6.1.1, 6.1.3 and Fig. 6.1.1). The greatest decrease was found in the first period, after which the ferritin was stable. In females there was a slight increase of the ferritin levels which can be attributed to the iron supplementation.

Regarding the findings mentioned before we could not demonstrate a diminished erythropolesis. Nevertheless special attention has to be paid to the iron status in athletes to avoid the risk of developing an iron deficiency (females, users of analgetic drugs, vegetarians).

\section{References}

1 Bas B.M., Costongs G.M.P.J., Janson P.C.W., van Wersch J.W.d.: The determination of haematologic reference values with a fully automated electronic counter. Proc of the $V$ th Eur. Congress of Clinical Chemistry $139,1983$.

2 Baynes R.D., Flax H., Bothwell T.H., et al: Red blood cell distribution width in the anemia secondary to tuberculosis. A.J.C.P. pp 226-229,1986.

3 Bessman J.D., Rldgway Gilmer P., Gardner F.H.: Improved classification of anemias by MCV and RDW. A.J.C.P. BO(2): 322-326, 1983 .

4 Bezwoda W.R., Bothwell T.H., Tonnance J.D. et al:" The relationship between marrow iron stores, plasma ferritine concentrations and iron absorption. Scand J Hematology 22; 113-120,1979.

5 Buick F.J., Gledhill $N_{\text {, }}$ Froese A.B.y Spriet L. et al: Effect of induced erythrocytemia on aerobic work capacity. $\$ Appl Physiol 48(4):636-642,1980.

6 Casonl I., Borsetto C., Caulcchl A., Marlinelli $S_{\text {, }}$ and Conconi F.: Reduced hemoglobin concentration and red cell hemoglobinisation in Italian marathon and ultra-marathon runners. Int $J$ Sports Med 6:176-179,1985.

7 Clement D.B., Asmundson R.S.: Nutritional intake and haematological parameters in endurance runners. Physiclan and Sports Medicine 10(3):37-43,1982.

8 Clement D.B., Sawchulk L.L.: Iron status and sports pertormance. Sports Medicine 1:65-74,1984.

9 Colt E., Heymann B.: Low ferritin levels in runners. \Sports Med 24:13-17,1984.

10 Conrad M.E., Barton J.C.: Factors affecting iron balance. Am Hematology 10:199-255,1981.

11 Cook J.D. A. Clement, A. Finck: Assessing Iron status of a population. Am J Clin Nutr 32:2115-2119,1979.

12 Costongs G.M.P.J. Janson P.C.W., Bas B.M., Brombacher P.J., van Wersch J.W.J.: Short-term and long-term intra-individual 
variations and critical differences of haematological laboratory parameters. J Clin Chem Biochem 23:69-76,1985.

13 Davidson R.J.L., Robertson J.D., Galea G., and Maughan R.J.: hematological Changes associated with marathon running. Int $J$ Sports Med 8:19-25,1987.

14 Dickson D.N., Wilkinson R.L.,Noakes T.D.: Effects of ultramarathon training and racing on haematoloci parameter and serum ferritin levels in well trained athletes. Int $\mathrm{J}$ Sports Med 3:111-117,1982.

15 Dufaux B., Hoederath A., Streitberger I., Hollmann $W_{\text {, }}$ Assmann G.: Serum ferritin, transierrin, haptoglobin and iron in middle and long-distance runners, elite rowers and professional racing cyclists. Int J Sports Med 2:43-46,1981.

16 Ehn L., Cartmauk B., Hoglund S.: Iron status in athletes involved in intense physical activity. Med and Science in Sports and Exercise 12(1):61-64,1980.

17 Elchner R.E.: Runner's macrocytosis: A clue to footstrike hemolysis. Am J Med 78:321-325,1985.

18 Frederickson L.A., Puhl J.L., Ruuyan W.S.: Effects of training on Indices of iron-status of young female cross -country runners. Med and Sclence Sports and Exercise 15(4):271-276,1983.

19 Galea $G_{\text {., }}$ Davidson R.J.L.: Hemorrheology of marathon running. Int d Sports Med 6:136-138,1985.

20 Hallberg L., Magnussen B.: Etiology of "Sports anemia". Acta Med Scand 216:145-148,1984.

21 Hallberg L., Rossander L.: Absorption of iron from Western type lunch and dinner meals. Am J Clin Nutr 35:502-509, 1982.

22 Hegenauer J., Strause L., Saltman P. et al: Transitory hematological effects of moderate exercise are not influenced by iron supplementations. Eur $\downarrow$ Appl Physiol 52:57-61,1983.

23 Heilman E., Lunke G., Behr J., Schmidt J.: Untersuchungen zur mechanisch bedingten Hamolyse nach verschiedenen sportlichen Ubungen. Deutsche Zeitschrift Sportmed. 10:291-294,1978.

24 Hoepelman. Bloedarmoede door sportbeoefening: een onschuldige bijwerking van een gezonde hobby. NTvG pp 155-157,1986.

25 Hunding A., Jordal R., and Paulev P.E.: Runners anemia and Iron deficiency. Acta Med Scand 209:315-318,1981.

26 Kaiser V., Janssen G.M.E., Wersch van J.W.J.: Sweat excretion of iron in long distance runners. Annals of Clin Blochem, Suppl. 2:60,1987.

27 Linderman R., Ekanger R., Opstad P.K. et al: Hematological changes in normal men during prolonged severe exercise. J Am Corr Them 32(4):107-111,1978.

28 Magnussen B., Hallberg L., Rossander L., Swolin B.: Iron metabolism and "sports anemia" I, II. Acta Med Scand 216:149 $-164,1984$.

29 Milman N., Spudergaard M.: Iron stores in male blood donors evaluated by serum ferritin. Transfusion 14(6),1984.

30 Morck T.A., Lynch S.R., Cook J.D.: Inhibition of food iron absorption by coffee. Am J Clin Nutr 37:416-420,1983. 
31 Ohira Y., Edgerton V.R., Gardner G.W. et al.: Work capacity after iron treatment as a function of haemogllobin and iron deficiency. $J$ Nutr Sci Vitaminology $27: 87-96,1981$.

32 Pate R.: Sports anemia: a review of the current research literature. Phys and Sports Med 11(2):115-131,1983.

33 Paulev P.E., Jordal R., Strandberg Pederson. N.: Dermal excretion of iron in intensively training athletes. Clin Chem Acta 127:19-27,1983.

34 Plowman S.A., McSwegin: The effects of iron supplementation on female cross-country runners. J Sports Med 21:407-415,1981.

35 Radomski M.W., Sabiston B.H., Isoand P.: Development of "sports anemia" in physically fit men after dally sustained submaximall exercise. J Space and Environ Med pp 41-45,1980.

36 Robertson J.D., Maughan R.J., Davidson R.J.L.: Faecal blood loss in response to exercise. B M J 295:303-305,1987.

37 Stäubll M., Roessler B.: The man cell volume in long distance runners. Eur J Appl Physiol 55:49-53,1986.

38 Stewart J.G., Ahlquist D.A., McGill D.B. et al.: Gastro-intestinal blood loss and anemia in runners. Ann of Int Med 100(6): 843-845, 1984.

39 Taylor C., Rogers G., Goodman C., Baynes R.D.: Hematologic, iron related, and acute-phase proteln responses to sustained strenuous exercise. J Appl Physiol 464-469,1987.

40 Thomson J.M., Stone J.A., Ginstreng A.G., Hamilton P.: $\mathrm{O}_{2}$ transport during exercise following blood reinfusion. $J$ Appl Physiol 53:1213-1219,1982.

41 Vellar. Studies on sweat losses of nutrients. Scand J Lab Invest 21:157-167,1968.

42 Videus A., Opstad P.K.: Serum ferritin in young men during prolonged heavy physical exercise. Scand J Haem 27:165-170, 1981.

43 Wijn de, Jongste de J.L., Mosterd W., Willebrand D.: Haemoglobin, packed cell volume, serum iron and iron binding capacity of selected athletes during training. J Sports Med Phys Fitness 11:42-51,1971.

44 Williamson M.R.: Anemia in runners and other athletes. Phys and Sports Med 9(6):73-79,1981.

45 Wishnitzer R., Vorst E., Berrebl A.: Bone marrow Iron depression in competitive distance runners. Int J Sports Med 4:27-30,1983.

46 Yoshimura H.: Anemia during physical training; sports anemia. Nutrition Reviews 28:251-253,1970. 


\subsection{White cell system changes associated with a training period of 18-20 months: a transverse and a longitudinal approach}

\section{Introduction}

The influence of physical stress on leukocytes has not been well established yet. On the one hand an increased vulnerability to infection has been observed in well trained athletes $(9,16,17,23,26)$ especially in a perlod of more physical stress and this vulnerability has been associated with leukocytosis after physical exercise $(7,8,12,14,15,19,22,24)$. On the other hand in a recent study it has been reported that long lasting physical exercise elicits activation of monocytes and macrophages (4), which subsequently produce endogenous pyrogen (interleukin-1), which induces a large increase of elastase-1-proteinase inhibitor complex. This complex is released by granulation of neutrophils (20). Besides, physical exercise can induce Iymphocytosis (13). Circulating lymphocytes have recently been identified as "natural killer" (NK) cells (16).

For a long time leukocytosis has been observed to occur shortly after physical exercise. But the amount of the leukocytosis

associated with physical exercise appears to depend primarily on the exercise intensity rather than on its duration. Similar changes in the number of leukocytes can be elicited by administration of epinephrine and adrenocortical steroids $(2,10)$.

The degree of granulocytosis and monocytosis after a 20 miles' run not only depends on the stress, but is also positively correlated with serum cortisol concentration and inversely with the intensity of a previous training session (19). A decrease in the number of eosinophils appears after application of cortisol, too. Upon this decrease of the number of eosinophils an adrenocortical function test has been based (25).

Changes in the number of leukocytes and in the number of most of the subpopulations are induced by adrenocortical steroids, which can influence the bone marrow. Thus an intravenous epinephrine infusion may induce changes of the white cells in the blood.

Besides, steroid hormones have been associated with an increase in the release of neutrophils into the circulation and with a decrease of the efflux of neutrophils from the blood as well as with the increased efflux of eosinophils and lymphocytes from the blood to tissues (27).

The aim of the present study was to monitor possible changes of the number of leukocytes and the number of the subpopulations in untrained males and females who followed a standardized training of 18-20 months to run a marathon. 
Materials and methods

\section{Subjects}

The selection of the participants has been described on p. 121 (Chapter 6.1).

White blood cell variables

The hematological variables of the white blood cell system which have been determined in the seven blood samples are: number of leukocytes and number of neutrophils, lymphocytes, monocytes, eosinophils and basophils $\left(10^{\circ} \cdot 1^{-1}\right)$. The percentage of leukocytes with a larger peroxidase activity was also determined (HPX,\%). Statistical analysis.

The statistical analysis is done in the same way as described in Chapter 6.1.1 on p. 122.

The values of peroxidase leukocytes (\%) of the samples 1 to 7 are described using box-and-whisker plots (Fig. 6.2.1).

The long-term coefficients of analytical variance of the variables have been described in Chapter 2 (p. 34).

\section{Results}

\section{Transverse approach}

Total number of leukocytes.

The means of the samples are given in Table 6.2.1. The total number of leukocytes hardly changed in males, but in females there was a larger range in the 7 blood samples. In comparison to the start of the study no influence of training or contests could be demonstrated. However, a significant decrease appeared in males during the first two training periods (sample 1-4;p=0.005) and in females in the course of the third period (sample 1-6;p=0.009).

Subpopulations of leukocytes.

The number of the neutrophils during the whole training perlod is presented in Table 6.2.1. No significant differences were demonstrated between males and females during the present study.

The mentioned significant decreases in the number of leukocytes appeared to run parallel with the changes in neutrophils. In males the significant decrease occurred after period 2 (sample $1-4 ; p=0.004$ ) and in females after period 3 (sample $1-6 ; p=0.031$ ).

The training and the contests (period 1,2 and 3) did not have any influence on the numbers of lymphocytes, monocytes and eosinophils in males nor in females.

The basophils demonstrated a significant increase in males $(p=0.007)$ from the start until after the $15 \mathrm{~km}$ contest (sample 1-3). In females there was a significant increase of basophils $(p=0.025)$ after period 2 (sample 1-5). Besides, sígnificant increases were observed after the 15 and $42 \mathrm{~km}$ contest (M:sample 2-3;p $=0.038$ and F:sample $7-6 ; p=0.036$ ).

The eosinophils demonstrated significant increases after the 25 and $42 \mathrm{~km}$ contests (M:sample 4-5;p=0.01 and F:sample 6-7; $p=0.04$ ). The monocytes demonstrated a significant increase after the $42 \mathrm{~km}$ 
contest in males (sample 6-7;p=0.027) and a tendency to increase after the 15 and $42 \mathrm{~km}$ contests in females $(p<0.1)$.

HPX (peroxidase active) cells.

In Fig. 6.2.1 the time course of the \% of HPX-cells is depicted:

Both in males and females a continuous decrease was observed from the start of the study, while the standard deviation also decteaced (Table 6.2.1 and 6.2,3). During the 3 training periods the phows. decreased succesalvely in males and females in period 1 (buplo 1-2) from $p>0.1$ and $p>0,1,10, p=0,099$ and $p<0,001$ in perlets (sample 14) and $p<0,001$ and $p=6.005 \| n$ (jetiod 3 (sample 1-6), There was no change in the correlation between the HPX cells and the leukocytes during the study.

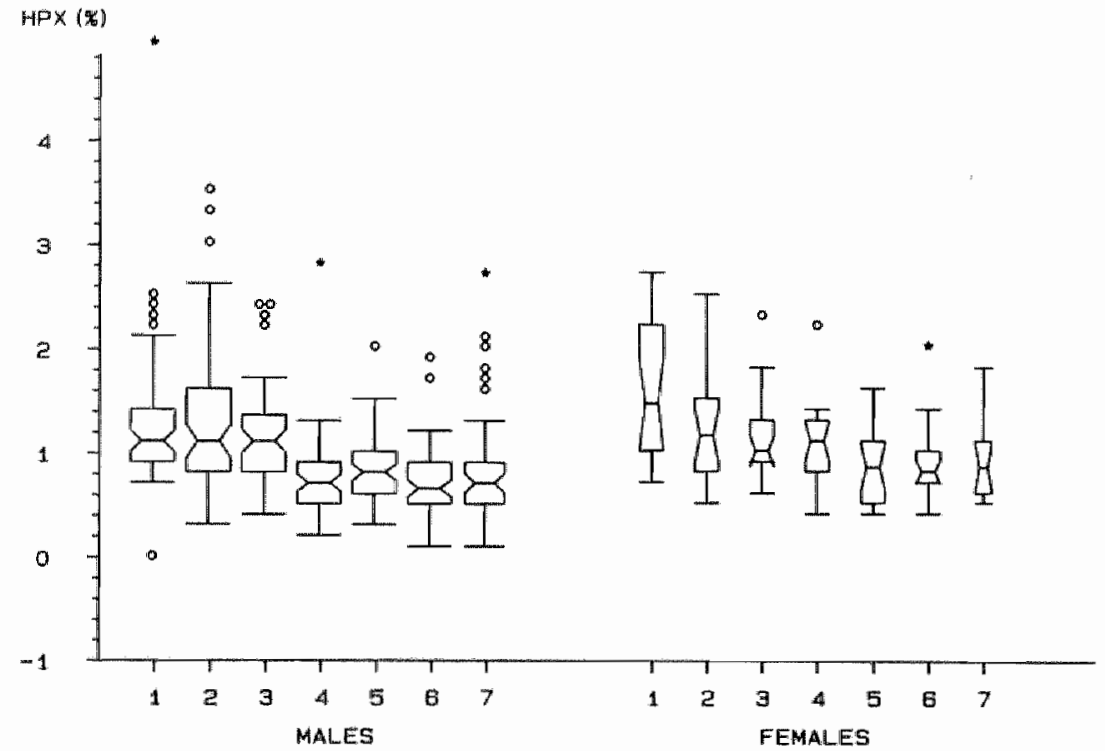

Flg. 6.2.1 Box-and-whIsker plots of peroxldase act/ve leukocytes (HPX; \%) during the trainlng perlod (start, before and after each contest). 
Table 6.2.1 Number of leukocytes, Iymphocytes, neutrophlls, monocytes, eoslinophils, basophlis and the MPX cells in males before and after the 15,25 , and $42 \mathrm{~km}$ contests

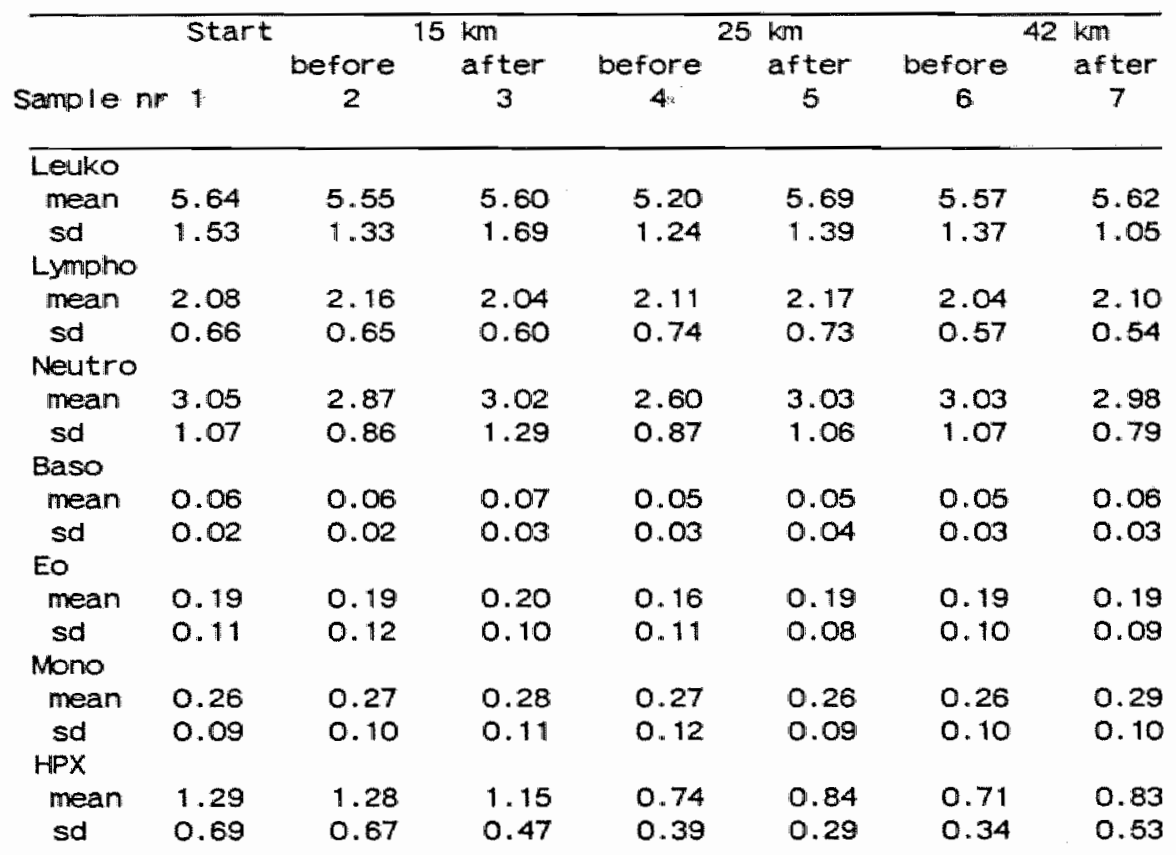

Mean values \pm sd $\left(10^{9}, 1^{-1}\right)$

Peroxldase act Ive leukocytes (HPX) in \% of number of leukocytes.

Table 6.2.2 Resullts of WIlcoxon tests (two-way) concerning leukocyte count and number of subpopulations of the leukocytes in males

\begin{tabular}{|c|c|c|c|c|c|c|c|c|c|}
\hline Sample & $2 / 1$ & $4 / 1$ & $6 / 1$ & $3 / 2$ & $5 / 4$ & $7 / 6$ & $2 / 4$ & $2 / 6$ & $4 / 6$ \\
\hline Leuko & ns & 0.005 & ns & ns & 0.001 & ns & 0.003 & ns & ns \\
\hline Lymph & ns & ns & ns & 0.009 & ns & ns & ns & 0.012 & ns: \\
\hline Neut & ns & 0.005 & ns & ns & 0.008 & ns & 0.010 & ns & ns: \\
\hline Baso & ns & 0.032 & ns & 0.038 & ns & ns & ns & ns & ns \\
\hline Eo & ns & ns & ns & ns & 0.010 & ns & 0.012 & ns & ns \\
\hline Mano & ns & ns & ns & ns & ns & 0.023 & ns & ns & ns \\
\hline HPX & ns & 0.009 & $<0.001$ & 0.013 & ns & ns & 0.001 & 0.050 & ns \\
\hline
\end{tabular}


Table 6.2.3 Number of leukocytes, Hymphocytes, neutrophils, monocytes, eosinophils, basophils and the HPX cells in females before and after the 15,25 and $42 \mathrm{~km}$ contests

\begin{tabular}{|c|c|c|c|c|c|c|c|}
\hline & start & & & & & 42 & \\
\hline Sample $n$ & r 1 & $\begin{array}{c}\text { before } \\
2\end{array}$ & $\begin{array}{c}\text { after } \\
3\end{array}$ & $\begin{array}{c}\text { before } \\
4\end{array}$ & $\begin{array}{c}\text { after } \\
5\end{array}$ & $\begin{array}{c}\text { before } \\
6\end{array}$ & $\begin{array}{c}\text { after } \\
7\end{array}$ \\
\hline Leuko & & & & & & & \\
\hline mean & 5.80 & 6.47 & 6.08 & 6.24 & 6.39 & 5.35 & 6.31 \\
\hline sd & 1.27 & 2.37 & 1.50 & 2.39 & 1.52 & 1.13 & 1.26 \\
\hline Lympho & & & & & & & \\
\hline mean & 1.94 & 2.26 & 2.08 & 2.13 & 2.37 & 11.92 & 2.29 \\
\hline sd & 0.61 & 0.71 & 0.61 & 0.97 & 0.67 & 0.48 & 0.63 \\
\hline Neutro & & & & & & & \\
\hline mean & 3.36 & 3.64 & 3.46 & 3.65 & 3.53 & 2.96 & 3.38 \\
\hline sd & 0.91 & 1.76 & 1.27 & 1.81 & 0.92 & 0.85 & 0.80 \\
\hline Baso & & & & & & & \\
\hline imean & 0.05 & 0.06 & 0.06 & 0.06 & 0.07 & 0.05 & 0.07 \\
\hline sd & 0.03 & 0.04 & 0.02 & 0.04 & 0.03 & 0.02 & 0.02 \\
\hline Eo & & & & & & & \\
\hline mean & 0.117 & 0.17 & 0.18 & 0.15 & 0.18 & 0.16 & 0.24 \\
\hline sd & 0.09 & 0.10 & 0.11 & 0.09 & 0.13 & 0.10 & 0.11 \\
\hline Mono & & & & & & & \\
\hline mean & 0.28 & 0.34 & 0.29 & 0.25 & 0.25 & 0.25 & 0.33 \\
\hline sd & 0.12 & 0.12 & 0.10 & 0.15 & 0.07 & 0.08 & 0.18 \\
\hline $\mathrm{HPX}$ & & & & & & & \\
\hline mean & 1.57 & 1.24 & 1.16 & 1.06 & 0.89 & 0.89 & 0.92 \\
\hline sd & 0.63 & 0.59 & 0.45 & 0.41 & 0.35 & 0.37 & 0.41 \\
\hline
\end{tabular}

Mean values \pm sd $\left(10^{9} \cdot 1^{-1}\right)$

Peroxidase act Ive leukoccytes (HPX) in \% of number of leukocytes.

Table 6.2.4 Results of WIIlcoxon tests (two-way) concerning leukocyte count and number of subpopulations of the leukocytes in females

\begin{tabular}{|c|c|c|c|c|c|c|c|c|c|}
\hline Sample & $2 / 1$ & $4 / 1$ & $6 / 1$ & $3 / 2$ & $5 / 4$ & $7 / 6$ & $2 / 4$ & $2 / 6$ & $4 / 6$ \\
\hline Leuko & ns & $\mathrm{ns}$ & 0.009 & ns & ns & 0.036 & ns & ins & ns \\
\hline Lymph & ns & ns & ns & ns & ns & 0.026 & ns & 0.017 & ns \\
\hline Neut & ns & ns & 0.031 & ns & ns & ns & ns & ns & ns \\
\hline Baso & ns & ns & ns & ns & ns & 0.036 & ns & ns & ns \\
\hline Eo & ns & ns & ns & ns & ns & 0.036 & ns & ns & ns \\
\hline Mono & ns & ns & ns & ns & ns & ns & ns & 0.047 & ns \\
\hline HPX & ns & $<0.001$ & 0.005 & ns & ns & ns & ns & ns & ns \\
\hline
\end{tabular}




\section{Longitudinal effects}

In Table 6.2 .5 the degree of variability ( $\mathrm{N}_{\text {vari }} \%$ ) and the intraindividual coefficient of variation $\left(\mathrm{CV}_{\mathrm{poo}}\right)$ have been summarized for males and females. For the leukocytes $\mathrm{N}_{\mathrm{var}}$ and $\mathrm{CV}_{\text {pso }}$ could not be calculated in males nor in females.

Table 6.2.5 Comparison of whlte cell system of males and females during the course of the study

\begin{tabular}{lrrrrrr}
\hline & $\begin{array}{c}\text { Nvar } \\
\text { males females }\end{array}$ & $\begin{array}{c}\text { Nvar } \\
\text { ref }\end{array}$ & $\begin{array}{c}\text { CVp90 } \\
\text { males }\end{array}$ & $\begin{array}{r}\mathrm{CV}_{\text {p }} 90 \\
\text { females }\end{array}$ & $\begin{array}{c}\text { CV } \\
\text { p9o } \\
\text { ref }\end{array}$ \\
\hline Leuco & 0 & 6 & 86 & 0.0 & 0.0 & 17.3 \\
Neutro & 100 & 100 & 98 & 34.8 & 43.1 & 12.5 \\
Lymfo & 100 & 100 & 100 & 26.5 & 32.5 & 21.3 \\
Mono & 91 & 100 & 97 & 41.2 & 59.9 & 30.7 \\
Eo & 88 & 83 & 97 & 42.8 & 48.7 & 41.3 \\
Baso & 3 & 0 & 96 & 0.0 & 0.0 & 56.9 \\
HPX & 0 & 0 & 74 & 0.0 & 0.0 & 49.1
\end{tabular}

In the subpopulations i.e. neutrophils, lymphocytes, monocytes and eosinophils a high variability was observed (88-100\%). The matched $\mathrm{CV}_{\text {poo }}(\%)$ values in males and females for the mentioned cell types were $34.8 / 43.1 ; 26.5 / 32.5 ; 41.2 / 59.9$ and $42.8 / 48.7$, respectively. For basophils and HPX-cells no variability could be demonstrated.

\section{Discussion}

The increase in the number of leukocytes after short and long lasting exercise described in literature was not observed one week after the contests in this study $(7,12,14,15,19,22)$. It also became clear that in the blood samples of the present study there was no change due to training or contests in the number of lymphocytes and neutrophils, but the number of eosinophils, basophils and monocytes showed an increase one week after the contests $(18,21)$. This can probably be explained as post-exercise stress.

After the marathon the number of leukocytes was greater in females than in males. This increase may be ascribed to the increase of neutrophils. However, statistical significance could not be demonstrated. Finally a continuous decrease of the percentages of HPX-cells was observed in males and females. This decrease was statistically significant in the blood samples before each contest (samples 2,4 and 6) in comparison to the blood sample at the start of the study (sample 1). A decrease in the number of leukocytes with a larger peroxidase activity (HPX-cells) Indicates that the composition of neutrophils is qualitatively more homogeneous. No significant correlation was observed between the plasma cortisol concentration and the number of eosinophils, indicating that there were no stressful situations one week before and after the contests (Chapter 4.2; p. 73).

The longitudinal study shows a remarkably low varlability of the leukocytes in comparison to the results of the study of

Costongs et al. (6). These findings suggest that a homogeneous 
population of leukocytes has been developed with respect to number and age (1).

When considering the coefficient of variation in the amounts of neutrophils, lymphocytes, monocytes and eosinophils, there appeared to be a larger variability in these subpopulations of leukocytes in the volunteers of the present study than in those in the study of Costongs et al. (6). Especially in femalles the variability ( $C V_{p o o}$ ) appeared to be rather large (Table 6.2.5). This varlability can probably be attributed to the influence of cortisoll and other steroid hormone concentrations which change after physical stress for a period of time $(3,5,11)$. Due to the frequent training sessions the release of the hormones induces a regular release of leukocytes and also shifts occur in the distribution of the subpopulation of the leukocytes (27). This can be an explanation for the large intraindividual variations in the subpopulations of leukocytes, which can hamper a correct interpretation of diagnostic investigations after strenous exercise.

\section{Aeferences}

1 Atamer M.A., Groner W.: Investigation of the left shift with peroxidase chemistry of Hemalog D. Technicon International Congress, New York, U.S.A., 1972. Advances in Automated Analysis. 3:33-36,1973.

2 Bishop C.R., Athens J.W., Boggs D.R., Warner H.R.: Leukokinetic studies XIII. A non-steady state Kinetic evaluation of the mechanism of cortisone induced granullocytosis. J Clin Invest 47:249-260,1968.

3 Brandenberger G.:Cortisol responses to exercise and their interaction with diurnal peaks, in Fotherby K., Pal S.B. (eds): Exercise endocrinology. W. de Gruyter, Berlin,47-64,1985.

4 Cannon J.G., Kluger M.J.: Endogenous pyrogen activity in human plasma after exerclse. Science 220:617-619,1983.

5 Cashmore G.C., Davies C.T.M., Few J.D.: Relationship between Increases in plasma cortisol concentration and rate of cortisol secr"etion during exercise in man. J Endocr 72: 109-110,1977.

6 Costongs G.M.P.J., Janson P.C.W., Bas B.M., Brombacher P.J., Wersch van J.W.J.: Short-term and long-term intra-individual variations and critical differences of haematological laboratory parameters. J Cllin Chem Blochem 23:69-76,1985.

7 Davidson R.J.L., Robertson J.D., Galea G., and Maughan R.J.: Hematological Changes associated with marathon running. Int $\mathrm{J}$ Sports Med 8:19-25,1987.

8 Dickson D.N., Wilkinson R.L.,Noakes T.D.: Effects of ultramarathon training and racing on haematologic parameter and serum ferritin levels in well trained athietes. Int $\mathbf{J}$ Sports Med 3:111-117, 1982.

9 Edwards A.J., Bacon T.H., Elms C.A., Verardi R., Fekler M., Knight S.C.: Changes in the population of Iymphoid cells in human peripheral blood following physical exercise. Clin Exp Immunol 58:420-427,1984. 
10 Fauci A.S., Dale D.C.: The effect of in vivo hydrocortisone on subpopulations of human lymphocytes. $J$ Clin Invest 53 : 240-246,1974.

11 Few J.D.: Effect of exercise on the secretion and metabolism of cortisol in man. J Endocr 62: 341-353, 1974.

12 Galun E., Burstein R., Assia E., Tur-Kaspa I., Rosenblum and Epstein $Y$ :: Changes of white blood cell count during prolonged exercise. Int J Sports Med 8:253-255,1987.

13 Garrey W.E., Bryan W.R.: Variations in white blood cell counts. Physiol Rev 15:497-638,1985.

14 Gimenez M., Mohan-Kumar T., Humbert J.C., de Talance N., Buisine J.: Leukocyte, lymphocyte and platelet response to dynamic exercise. J Sports Med 27:172-177,1987.

15 Gimenez M. Mohan-Kumar T., Humbert J.C., de Talance $\mathbf{N}_{\text {.. }}$ Buisine J.: Leukocyte, lymphocyte and platelet response to dynamic exercise. Duration or intensity effect? Eur $\downarrow$ Appl Physiol 55:465-470,1986.

16 Green R.L., Kaplan S.S., Rabin B.S., Stanitski C.L., Zdziarski U.: Immune function in marathon runners. Ann of Allergy 4:73-75,1981.

17 Hanson P.G., Flaherty D.K.: Immunological responses to training in conditioned runners. Clin Sci 60:225-228,1981.

18 Lowe G.D.O., Machado S.G., Krol W.F., Barton B.A., and Forbes C.D.: White blood cell count and haematocrit as predictors of coronary recurrence after Myocardial infarction.. Thromb and Haemost 54(3):700-703,1985.

19 Moorthy A.V., Zimmerman W.: Human leukocyte response to an endurance race. Eur J Appl Physiol 38:271-276,1978.

20 Neumann S., Gunzer G., Henrich $\mathbf{N}_{\text {. }}$ Lang H.: PMN-Elastase assay: enzyme immunoassay for human polymorphonuclear elastase complexed with alpha-proteinase Inhibitor. J Clin Chem Clin Biochem 22:693-697,1984.

21 Oyster $\mathbf{N}$.: Changes in plasma eosinophils and cortisol of women in competition. Med Sci Sports Exerc 12:148-152,1980.

22 Plass R., Kokot K., Schaefer R.M., Teschner M., Gilge U., und Heidland A.: Auswirkung von Mittel- und Langstreckenlaut auf polymorphkernige Leukozyten. Deutsc Zeltschr Sportmed 38 (4): 168-172, 1987.

23 Schaefer R.M., Kokot K., Heldland A., and Plass R.: Jogger's leukocytes. Short commun. to editor, New Eng J Med 316 (4): $223,1987$.

24 Taylor C., Rogers G., Goodman C., Baynes R.D.: Hematologilc, iron-related, and acute-phase protein responses to sustained strenuous exercise. J Appl Physiol 62(2):464-469,1987.

25 Thorn G.W., Forsham P.H, Prunty F.T.G.: Test for adrenal cortical insufficiency JAMA 137:1705-1009,1948.

26 Tomasi T.B., Trudeau F.B., Czerwinski D., Erredge S.: Immune parameters in athletes before and after strenuous exercise. $\mathbf{J}$ Clin Immun 2:173-178,1982.

27 Wintrobe M.W. (ed): Cllinical Hematology. Philadephla, Lea \& Febiger 1981, p 215-217. 
6.3 Platelet system changes associated with a training period of 18-20 months: a transverse and a longitudinal approach

\section{Introduction}

Influences of physical stress on coagulation and fibrinolysis are well documented $(6,11,12,14,19,25)$. Generally the obtalned data show that in both systems pronounced changes occur through physical exercise. Several studies also demonstrate an increase in the number of thrombocytes and in thrombocytic functions after short lasting hard physical stress $(7,9,10,18,20)$.

The increase in the number of platelets can be induced by release of thrombocytes from the spleen and from an intravascular pool found in the pulmonary circulation $(13,21,26)$.

Besides, it has been described that under normal circumstances females have a larger number of circulating platelets than males $(1,2,22)$.

the aim of the present investigation was to study the changes of the number of thrombocytes, the mean platelet volume (MPV), the platelet distribution width (PDW) and the plateletcrit (PCT) during a period of a standardized training of 18-20 months in males and females.

\section{Materials and methods}

\section{Subjects}

The selection of the participants is described on p. 121 (Chapter 6.1).

\section{Platelet variables}

The hematological varlables of the platelet cell system which have been determined in the seven blood samples are: number of thrombocytes $\left(10^{\circ} .1-1\right)$, mean platelet volume (MPV, fl), platelet distribution width (PDW, \%), and plateletcrit (PCT, 1.1-i). PDW is detined as the ratio of the width of the frequency distribution curve at half-high of the maximum of the distribution curve divided by the corresponding platelet volume multiplied with $100 \%$.

\section{Statistical analysis.}

The statistical analysis is done in the same way as described in Chapter 6.1.1 on p. 122 .

The values of the plateletcrit $\left(\left.\mathrm{l.|}\right|^{-1}\right)$ of samples 1 to 7 are described using box-and-whisker plots (Fig. 6.3.1).

The long-term coefficlents of analytical variance of the variables have been described in Chapter 2 (p. 34). 
Results

Reterence vallues

The data of the thrombocyte variables, found at the start of the present study are summarized in the first column of Table 6.3.1 and Table 6.3.3 for males and females, respectively. They will serve as reference values. The means and standard deviations of the platelet count in males and females are $232 \pm 47.10^{\circ} .1^{-1}$ and $269 \pm 49.10^{\circ} .1^{-1}$, respectively. For the PDW these values are $43.8 \pm 1.8 \%$ and $43.0 \pm 1.8 \%$, respectively. There is no gender ditference in PCT (M $0.0021 \pm 0.0004$ I.I $\left.{ }^{-1} ; \mathrm{F} 0.0022 \pm 0.0004(.)^{-1}\right)$, which is the product of platelet count and MPV.

\section{Transverse approach}

\section{Platelet count}

The platelet count in males was significantly lower than in females, except in sample 6 (one week before the marathon race). The p-values between males and females in the 7 blood samples were: $0.002,0.007,0.003,0.005,0.001,0.147$ and 0.001 , respectively. There were no significant changes in platelet count after the first two periods of training in males nor in females. During the last period of training there was a significant decrease In comparison to the start in males $(p<0.001)$ and in females $(p=0.001)$. After the 25 and $42 \mathrm{~km}$ contests there was a significant increase in males and females $(p=0.045$ and $p=0.01$, respectively). After the $15 \mathrm{~km}$ contest the platelet count decreased significantly in males $(p=0.014)$.

Platelet distribution width (PDW)

In Table 6.3.1 and 6.3.3 the means of PDW demonstrate at first a decrease until after the $15 \mathrm{~km}$ contest in males and in females and an increase to the pre-study values in samples 4 and $5(25 \mathrm{~km}$ contest) and finally a slight decrease in males and in females during the training in the third period of the study and after the marathon.

The decrease until after the $15 \mathrm{~km}$ contest (sample 1-3) was only significant in males $(p=0.022)$, but the decrease until after the marathon (sample 1-7) was significant in both males and females $(p=0.021$ and $p=0.014)$. A significant decrease was observed in males atter the $15 \mathrm{~km}$ contest (sample 1-3;p=0.031).

Gender differences were observed at the beginning of the study and during the last year of training (sample 4-7; $M>F$; all p-values between 0.032 and 0.004 ). They were not demonstrated after the first 6 months of training and after the $15 \mathrm{~km}$ contest (sample 2 and 3).

Mean platelet volume (MPV) In Table 6.3.1 and Table 6.3.3 mean values of MPV are given of males and females who showed a similar pattern durling the study. There was a significant decrease in males and females in period 1 (sample 1-2; $M p<0.001$ and $F p=0.011$ ) and a significant increase after the $15 \mathrm{~km}$ contest (sample $2-3 ; M p=0.030$ and $F p=0.01$ ). 
After period 2 the level of the values before the $15 \mathrm{~km}$ contest was nearly reached (sample 1-4; $M p<0.001 ; F p=0.044$ ). A similar levell was seen before the $42 \mathrm{~km}$ contest ( $M p<0.001 ; F \quad p=0.007$ ). Gender differences were demonstrated at all moments except for the measurements after the contest of $15 \mathrm{~km}$ (sample $3 ; \mathrm{M}>\mathrm{F}$; all $\mathrm{p}$-values between 0.045 and 0.005 ).

Table 6.3.1 Platelet count, platelet width distrlbution, plateletorit and mean platelet volume in malles before and after the 15,25 and $42 \mathrm{~km}$ contest

\begin{tabular}{|c|c|c|c|c|c|c|c|}
\hline & Start & 15 & $\mathrm{~m}$ & 25 & $\mathrm{~km}$ & 42 & $\mathrm{~m}$ \\
\hline Sample & & $\begin{array}{r}\text { before } \\
2\end{array}$ & $\begin{array}{r}\text { after } \\
3\end{array}$ & $\begin{array}{r}\text { before } \\
4\end{array}$ & $\begin{array}{r}\text { after } \\
5\end{array}$ & $\begin{array}{r}\text { before } \\
6\end{array}$ & $\begin{array}{c}\text { after } \\
7\end{array}$ \\
\hline$\overline{P L T}$ & & & & & & & \\
\hline mean & 232 & 233 & 221 & 231 & 249 & 195 & 198 \\
\hline sd & 47 & 50 & 46 & 54 & 48 & 39 & 41 \\
\hline PDN & & & & & & & \\
\hline mean & 43.8 & 43.2 & 42.6 & 43.9 & 43.9 & 43.5 & 42.8 \\
\hline sd & 1.8 & 3.0 & 3.5 & 2.9 & 4.0 & 1.8 & 3.0 \\
\hline PCT & & & & & & & \\
\hline mean & 0.0021 & 0.0019 & 0.0019 & 0.0019 & D...0020 & 0.0015 & 0.0016 \\
\hline $\begin{array}{l}\text { sd } \\
M P V\end{array}$ & 0.0004 & 0.0005 & 0.0004 & 0.0005 & 0.0005 & 0.0004 & 0.0004 \\
\hline $\begin{array}{l}\text { MPV } \\
\text { mean }\end{array}$ & 9.03 & 8.23 & 8.54 & 8.33 & 8.30 & 7.90 & 7.83 \\
\hline $\mathrm{sd}$ & 0.78 & 0.79 & 0.83 & 0.86 & 0.91 & 0.63 & 0.65 \\
\hline
\end{tabular}

Mean values \pm sd $\quad\left(P L T, 10^{9} .1^{-1} ;\right.$ PDW, \%; PCT, $1.1^{-1} ;$ MPV, $\left.f 1\right)$

Table 6.3.2 Results of WIlcoxon tests (two-way) concerning platelet count and thrombocytic parameters in males

\begin{tabular}{lccccccccc}
\hline Sample & $2 / 1$ & $4 / 1$ & $6 / 1$ & $3 / 2$ & $5 / 4$ & $7 / 6$ & $2 / 4$ & $2 / 6$ & $4 / 6$ \\
\hline PLT & ns & ns & $<0.001$ & 0.014 & ns & ns & 0.001 & 0.005 & ns \\
PDW & ns & ns & ns & ns & ns & ns & ns & ns & ns \\
PCT & 0.003 & 0.010 & $<0.001$ & ns & ns & ns & ns & ns & ns \\
MPV & $<0.001$ & $<0.001$ & $<0.001$ & 0.030 & ns & ns & 0.012 & 0.008 & ns
\end{tabular}

Plateletcrit (PCT)

In Fig. 6.3.1 the values of PCT of males and females during the study are demonstrated using box-and-whisker plots. In females no changes of PCT were found up to the $25 \mathrm{~km}$ contest. In males, however, there was a significant decrease in the first period (sample 1-2; $p<0.001$ ) and in the second perlod (sample 1-4; $p=0.010$ ). During the last training period, preparing for the marathon, a significant decrease was observed in both groups $(\mathrm{p}<0.001)$.

The PCT in males was signiflcantly lower than in females after all contests $(p=0.011, p=0.052$, and $p=0.019$, respectively). 


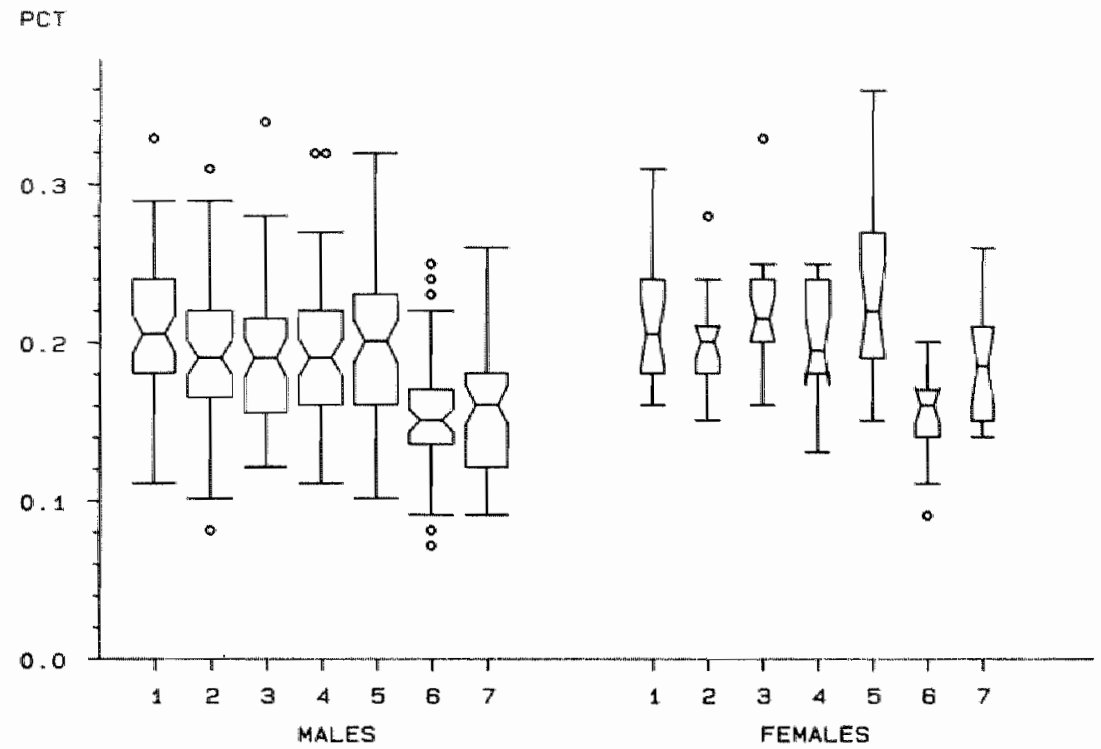

FIg. 6.3.1 Box-and-whlsker plots of platelletor It $\left(1.1^{-1} \times 10^{-2}\right)$ during the training perlod (start, before and after each contest).

Table 6.3.3 Platelet count, platelet width distribution, plateletcrit and mean platelet volume in females before and after the 15,25 and $42 \mathrm{~km}$ contest

\begin{tabular}{|c|c|c|c|c|c|c|c|}
\hline \multirow[b]{2}{*}{ Sample } & Start & \multicolumn{2}{|c|}{$15 \mathrm{~km}$} & \multicolumn{2}{|c|}{$25 \mathrm{~km}$} & \multicolumn{2}{|c|}{$42 \mathrm{~km}$} \\
\hline & & $\begin{array}{r}\text { before } \\
2\end{array}$ & $\begin{array}{r}\text { after } \\
3\end{array}$ & $\begin{array}{r}\text { before } \\
4\end{array}$ & $\begin{array}{r}\text { after } \\
5\end{array}$ & $\begin{array}{r}\text { before } \\
6\end{array}$ & $\begin{array}{c}\text { after } \\
7\end{array}$ \\
\hline$\overline{P L T}$ & & & & & & & \\
\hline mean & 269 & 260 & 257 & 263 & 288 & 209 & 248 \\
\hline sd & 49 & 38 & 42 & 43 & 64 & 44 & 48 \\
\hline PDW & & & & & & & \\
\hline $\begin{array}{l}\text { mean } \\
\text { sd }\end{array}$ & $\begin{array}{r}43.0 \\
1.8\end{array}$ & $\begin{array}{r}43.0 \\
2.5\end{array}$ & $\begin{array}{r}41.5 \\
2.5\end{array}$ & $\begin{array}{r}42.7 \\
2.8\end{array}$ & $\begin{array}{r}43.3 \\
3.6\end{array}$ & $\begin{array}{r}41.9 \\
2.3\end{array}$ & $\begin{array}{r}40.8 \\
1.9\end{array}$ \\
\hline $\begin{array}{l}\text { PCT } \\
\text { mean } \\
\text { sd }\end{array}$ & $\begin{array}{l}0.0022 \\
0.0004\end{array}$ & $\begin{array}{l}0.0020 \\
0.0003\end{array}$ & $\begin{array}{l}0.0022 \\
0.0004\end{array}$ & $\begin{array}{l}0.0020 \\
0.0004\end{array}$ & $\begin{array}{l}0.0023 \\
0.0006\end{array}$ & $\begin{array}{l}0.0016 \\
0.0030\end{array}$ & $\begin{array}{l}0.0019 \\
0.0004\end{array}$ \\
\hline $\begin{array}{l}\text { MPV } \\
\text { mean } \\
\text { sd }\end{array}$ & $\begin{array}{l}8.21 \\
0.93\end{array}$ & $\begin{array}{l}7.74 \\
0.63\end{array}$ & $\begin{array}{l}8.47 \\
1.17\end{array}$ & $\begin{array}{l}7.80 \\
0.69\end{array}$ & $\begin{array}{l}7.80 \\
1.00\end{array}$ & $\begin{array}{l}7.40 \\
0.58\end{array}$ & $\begin{array}{l}7.46 \\
0.61\end{array}$ \\
\hline
\end{tabular}

Mean values \pm sd $\quad\left(P L T, 10^{9}, 1^{-1}\right.$; PDW, \%; PCT, $1.1^{-1} ;$ MPV, f 1 ) 
Tabie 6.3.4 Riesults of Wll lcoxon tests (two-way) concerning pllatelet count and thrombocytic parameters (two-way) in females

\begin{tabular}{|c|c|c|c|c|c|c|c|c|c|}
\hline Sample & $2 / 1$ & $4 / 1$ & $6 / 1$ & $3 / 2$ & $5 / 4$ & $7 / 6$ & $2 / 4$ & $2 / 6$ & $4 / 6$ \\
\hline PLT & ns & ns & 0.001 & ns & 0.045 & ns & $\overline{\mathrm{ns}}$ & $s$ & ns \\
\hline PDW & ns & ns & ns & 0.031 & ns & ns & ns & ns & ns \\
\hline PCT & ns & $n s$ & 0.001 & 0.020 & ns & ns & ns & ns & ns \\
\hline MPV & 0.011 & 0.044 & ns & 0.010 & ns & ns & 0.035 & ns & ns \\
\hline
\end{tabular}

Longitudinal approach

In Table 6.3.5 $\mathrm{N}_{\text {var }}$ and $\mathrm{CV}_{\text {poo }}$ of the platelet count, PDW, MPV and PCT have been summarized for males and females. All the mentioned variables demonstrated large variations $(82-98 \%)$ and there were small gender differences. For platelet count it was $17.1 \%$ and $17.5 \%$, for PDW $6.9 \%$ and $6.1 \%$, for MPV $11.0 \%$ and $13.5 \%$ and for PCT $24.1 \%$ and $27.8 \%$ in malles and females, respectively.

Table 6.3.5 Nar and $\mathrm{CV}_{\mathrm{p} 90}$ : Comparlson of the platelet system of males and females dur Ing the course of the study

\begin{tabular}{lrrrrrr}
\hline & $\begin{array}{c}\text { Nvar } \\
\text { malles females }\end{array}$ & $\begin{array}{c}\text { Nvar } \\
\text { ref }\end{array}$ & & $\begin{array}{c}\text { CV } \\
\text { males }\end{array}$ & $\begin{array}{c}\text { CV p9o } \\
\text { females }\end{array}$ & \multicolumn{1}{c}{$\begin{array}{c}\text { CV90 } \\
\text { ref }\end{array}$} \\
\hline PLT & 87 & 89 & 49 & 17.1 & 17.5 & 10.6 \\
MPV & 98 & 94 & 89 & 11.0 & 13.5 & 8.0 \\
PDW & 82 & 89 & 73 & 6.9 & 6.1 & 6.3 \\
PCT & 88 & 89 & 95 & 24.1 & 27.8 & 20.6
\end{tabular}

\section{Discussion}

The platelet counts of the first blood samples of the present study were compared to the reference values as found in a healthy population and appeared to be In agreement with those studies $(1,2,3)$.

One year after the beginning of the training a decrease in platelet count was observed both in males and in females. However, an Increase was observed in the platelet count one week after the contests, probably induced by the physical stress of these contests $(5,7,18,19)$. The increase after physical stress can be attributed to delivery of platelets from the thrombocytic pool as a result of the physical activity (13). Even one week after the contests an increase of the numbers of thrombocytes was observed. This increase in platellet count might give additional information -together with other varlables- about the degree of recovery after physicall stress. The use of an automated analyzer (H6000 Technicon) and of K-EDTA as an anticoagulant $(17,23)$ may have influenced the results obtained. However, as sampling and measurement procedures were fully standardized for all blood samples in the present and reference study (3), a comparison of the values obtained is justified. Moreover the influence of training was only studied to compare samples 2,4 and 6 with sample 1 . 
In females PCT was always higher one week after the contest as compared to the values one week before the contest (Table 6.3.3). However, this increase only reached statistical significance in the 15 $\mathrm{km}$ contest, indicating that the response to physicall stress in females one week after the contests gradually became smaller during the study period $(1,2,22)$.

The decrease of PDW in males and females can be considered as a positive effect of the endurance training. A decrease of the PDW is indicative of a homogeneous population of smaller and less active thrombocytes, probably because the large thrombocytes, which are the most active ones in the coagulation process, are removed from the circulation $(24,25)$. Moreover the change in thrombocytic variables during the training periods induced a significant decrease of the PCT in males and females. It seems that the variation of some thrombocytic parameters was more demonstrable in males than in females. The PCT (depending on the platelet count, the mean platelet volume) demonstrated an increase one week after each contest.

According to the results of study of Janssen et al. $(15,16)$ regarding the moment of blood sampling, one week before and one week after the contests, the volunteers were expected to be in a steady state. However, for more than one hematological variable this was in fact not the case. Thus we suggest that recovery takes more time than a few days.

We may conclude that the decrease of PCT and the removal of the large platelets can be seen as positive effects due to physical exercise. A decrease of the plateletcrit with the removal of the large platelets implles a lowering of the platelet bounded coagulation capacity in the peripheral blood.

According to the longitudinal approach of the parameters it can be concluded that there is a large variability both in males and in females. The variability of the platelet count and to a lesser extent of the PDW is larger than in a study of subjectively healthy subjects who had not participated in a standardized training $(3,4)$. This suggests that especially cell kinetic changes due to physical exercise occur in the thrombocytes (number and distribution width). However, in both males and females there exists a larger IntraIndividual variation ( $\mathrm{CV}_{\mathrm{p}}$ ) ) for PLT, MPV and PCT than in the reference $(3,4 ;$ Table 6.3 .5$)$, which means that the small amount of subjects with a higher variation must have a very high variation. Finally we conclude that physical exercise as carried out in this study has a positive effect on the platelet system. A significant decrease of PLT and MPV was observed, which leads to a decrease of the PCT, representing the platelet bounded capacity of the peripheral blood.

Another aspect is that in a medical check-up of Intensively trained runners platelet count and MPV may have low values. An abruptly ending heavy physical exercise may lead to a rebound effect, which means an increase of coagulation potential.

Due to the high variabillty ( $\mathbb{N}_{\text {var }}$ ) and the high Intra-Individual variation $\left(C V_{p \infty o}\right)$ of all platelet parameters, except the $C V_{p o o}$ of the PDW, interpretation of results of diagnostlc investigations regarding platelets should be considered with respect to the current state of training. 


\section{References}

1 Bain B., Forster I.: A sex difference in the platelet count. Thromb. Haemost. 43:131-2,1980.

2 Bain J.B.: Platelet count and pllatelet size in males and females. Scand J Haematoll 35:77-79,1985.

3 Bas B.M., Costongs G.M.P.J.y Janson P.C.W., van Wersch J.W.J.: The determination of haematollogic reference values with a fully automated electronic counter. Proc of the Vth Eur. Congress of Clinical Chemistry 139,1983.

4 Costongs G.M.P.J., Janson P.C.W., Bas B.M., Hermans J., Brombacher P.J., van Wersch J.W.J.: Short-term and long-term intra-individual variations and critical differences of haematological laboratory parameters. $\Downarrow$ Clin Chem Clin Blochem 23:69-76,1985.

5 Davidson R.J.L., Robertson J.D., Galea G., and Maughan R.J.: Hematological Changes associated with marathon running. Int $J$ Sports Med 8:19-25,1987.

6 Davis G.L, Abildgaard C.F., Bernauer E.M., and Britton M.: Fibrinolytic and hemostatic changes during and atter maximale exercise in males. J Appl Physiol 40(3):287-292,1976.

7 Dawson A.A., Ogston D.: Exercise-induced thrombocytosis. Acta Haematol 42:241-246,1969.

8 Dessman J.D., Williams L.J., Gilmer P.R.: Mean platelet volume. The inverse relation of platelet size and count in normal subjects and an artefact of other particles. Am J Clin Patholl 76:289-293,1981.

9 Dickson D.N., Wilkinson R.L., Noakes T.D.: Effects of ultra -marathon training and racing on hematologic parameter and serum ferritin levels in well trained athletes. Int $\mathbf{J}$ Sports Med 3:111-117,1982.

10 Dix C.J., Hassall D.G., and Bruckdorfer R.: The Increased sensivity of platelets to prostacyclin in marathon runners. Thromb Haemostas 51(3):385-387,1984.

11 Drygas W.K., Rócker L., Boldt F., Heyduck B., und Altenkirch H.U.: Hämostase- und Fibrinolysesystem bel Gesunden und Herzinfarktpatienten. Dtsch med Wschr 112:995-999,1987.

12 Egeberg $0 .:$ The effect of exerclse on the blood clotting system. Scand J Clin Lab Inv 15:8-13,1963.

13 Freedman M., N. Altszuler, S. Karpatkin: Presence of a monosplenic platelet pool. Blood 50:419-425,1977.

14 Hulsveld I.A., Homers J.E.H., Bernink M.J.F., Erich W.B.M., Bouma B.N.: The effect of oral contrapetives and exercise on hemostatic and fibrinolytic mechanicms to trained women. Int $J$ Sports Med 4:97-103,1983.

15 Janssen G.M.E., Kuipers H., Keizer H., Verstappen F.: Plasma enzyme activities and running performance in a maximal treadmill test before and after a $30 \mathrm{~km}$ race or a marathon. Supplement Int J Sports Med 5:98-99,1984.

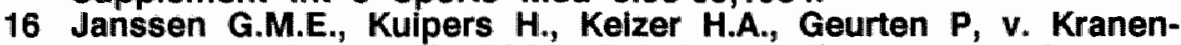
burg G., and Does R.J.M.M.: Splerbeschadigling, prestatievermogen en herstel na verschillende soorten wegwedstrijden. Gen Sport 20(5):190-195,1987. 
17 Lippi U., Cappelletti P.y Schinella M., and Signori D.: Mean Platelet Volumes: Facts or Artifacts? Am J Clin Pathol 84: 111-113,1985.

18 Masuhara M., Kami K., Umebayashi K., and Tatsumi N.: Effect of strenuous exercise on platelet. J Sports Med 27:178-183,1987.

19 Ohri V.C., Chatteril J.C., Das B.K., Akhtar M., Tewari S.C., Bhattacharji P., and Behl A.: Effect of submaximal exercise on haematocrit, platelet count, platelet aggregation and blood fibrinogen levels. J Sports Med and Phys Fitness 23 (2): $127-130,1983$.

20 Petursson S.R., and Chervenick P.A.: Effects of hypoxia on megakaryocytopoiesis and granulopolesis. Eur J Haematol 39: 267-273, 1987.

21 Schmidt K.G., Rasmusson J.W.: Exercise-induced changes in the in vivo distribution of $1 \mathrm{n}$-labelled platelets. Scand $\mathrm{J}$ Haematol 32:159-166, 1984 .

22 Stevens R.F., Alexander M.K.: A sex difference in the platelet count. Br J Haematol 37:295-300,1977.

23 Thompson C.B., Diaz D.D., Quinn P.G., Lapins M., Kurtz S.R., and Valeri C.R.: The role of anticoagulation in the measurement of platelet volumes. Am J Clin Pathol 80: 327-332,1983.

24 Trowbridge E.A., and Martin J.F.: The platelet volume distribution: A signature of the prethrombotic state in coronary heart disease? Thromb and Haemostas 58(2):714-717, 1987.

25 Warlow C.P., Ogston D.: Effect of exercise on platelet count, adhesion and aggregation. Acta Haematol. 52:47-52,1974.

26 Wintrobe M.W. (ed): Clinical Hematology. Philadephia, Lea \& Febiger 1981, $p$ 215-217. 


\section{Chapter 7 General discussion}

The marathon project, as described in this thesils, started in September 1984 with the enrollment of volunteers. Over 500 people responded to an article in the local newspapers in which the idea was launched to train, motivate and conduct untrained people to finally run a marathon after a training period of 18-20 months. The main objectives were to study the effects of the training programme and of running a marathon on a number of body functions and of recovery after running the marathon.

In October 198483 male and 31 female volunteers (age 21-54 years) started the training sessions. In the period April-May 1985 a $15 \mathrm{~km}$ contest was run by 76 males and 26 females. In September-October 1985 a $25 \mathrm{~km}$ contest was run by 72 males and 24 females. Finally from the group of 114 volunteers 60 males and 18 females ran a marathon in the period March-June 1986 with running times ranging from $3 \mathrm{~h} 04 \mathrm{~min}$ to $4 \mathrm{~h} 40 \mathrm{~min}$. Thus $68 \%$ of the volunteers who started the training actually completed a marathon.

The study started with a medical check-up Inciuding a maximal cycle ergometer test which was repeated after rumning the marathon. The training programme was divided Into 3 phases, each one concluded with a contest of increasing distance: phase 1 with a contest of $15 \mathrm{~km}$, phase 2 with one of $25 \mathrm{~km}$ and phase 3 with a marathon $(42.195 \mathrm{~km})$. The longest training run was $3-7 \mathrm{~km}$ shorter than the contest distance at the end of each period. The first exercise tests and determinations of other variables were carried out after 5-6 months training (Fig. 2.1), which means that training effects could only be studled between the 15 and $42 \mathrm{~km}$ contests. Three days before and 3 and 5 days after each contest the volunteers were either tested on a treadmill in the laboratory or in a fleld test. During these periods a number of variables determined before and after each contest was studied, permitting an estimation of performance (velocity in exercise tests, plasma lactate concentration and heart rate running at various treadmill speeds), changes in catabolism and anabolism (plasma urea, uric acid, creatinin, albumin, cortisol, testosterone and DHEAS concentrations), changes in skeletal muscle biochemistry (plasma muscle enzyme activity and muscle tissue content of energy rich substrates), changes in muscle morphology and hematological status of the volunteers. The repeated measurements allowed to study the effects of training, of contests and of recovery after each contest on the variables determined.

In each test period 3 muscle biopsies (one 5 days before and the other two 4-6 $\mathrm{h}$ and 8 days after the contest) and 3 exercise tests $\left(T_{1}, T_{2}\right.$ and $\left.T_{3}\right)$ were performed; in addition several blood samples were taken (Fig 2.2). 
Longitudinall evaluation of the results of all tests $T_{1}$ will give insight into training effects. Longitudinal evaluation of the results of $T_{2}$ and $T_{3}$ in relation to the corresponding tests $T_{4}$ will glve Information about influences of contests and recovery, respectively. Astrand and Rodahl (1) indicated a number of problems which are encountered in longitudinal studies with untralned people, which may hamper the interpretation of the results obtalined. These problems are selection of subjects, Intervention in the subjects' normal pattern of life, drop-out frequency, the initial training status and the composition of the training programme. As in the present study initial training status was defined, the training programme was standardized and the drop-out percentage was low, the data are obtained under unlform conditions whlch facilltates their interpretation.

\section{Training effects}

During the 18-20 months training period a number of the varlables measured changed while others did not, which is in accordance with data from literature $(1,59)$.

The maximal running speed in the exercise tests $T_{1}$ did not Increase In the course of the training (Table 3.1). This may be explained by the much larger amount of endurance runs (70-80\% max heart rate) compared to the amount of shorter runs at a higher pace $(80-95 \%$ max heart rate) in the training programme (Fig.2.3). This indicates that the training intensity after the $15 \mathrm{~km}$ contest was not high enough to increase the maximal speed, which is a parameter for aerobic power (1). Hickson (25) reported that the increase in maximal aerobic power was mainly attalned In the first 3 weeks of a training programme and the heart rate adaptation to standard submaximal exercise also occurred within 3 weeks. As our observations started after six months training, we thus cannot expect a rise in aeroblc power.

Submaximal speed at $4 \mathrm{mmol} . \mathrm{I}^{-1}$ plasma lactate concentration in the pre-contest exerclse tests gradually Increased In the experimental period (Table 3.1), suggesting that the endurance capaclty of the subjects was increased. Thls result supports the study of Heck et al. (24). The Increase of endurance capacity is Important for running a marathon which was the main training alm for the subjects.

The maximal workload measured with a blcycle ergometer at the beginning and at the end of the study Increased in males with $11.3 \pm 8.8 \%$ and in females with $11.0 \pm 12.0 \%$, respectively (Table 2.3). This increase was measured over the whole training period (1). However, one may expect (25) that this increase was already reached in the beginning of the training period.

it is generally accepted that physically very active people have at rest an increased urea and creatinin plasma concentration due to physical exercise and training, Indicating an increased catabollsm $(1,39,54)$. However, in the present study most of the variables used as indicators for catabolism such as urea, uric acid, creatinin and cortisol concentration, when measured at rest did not increase above 
the normal values with the increase of training (Fig. 2.3). Total protein increased only in males between the 15 and $42 \mathrm{~km}$ contest and albumin did not change in both sexes. Basal plasma creatinin concentration decreased between the 25 and $42 \mathrm{~km}$ contest compared to values before the $15 \mathrm{~km}$ contest. The indicators for catabolism thus did not increase in splte of an increased training volume. This might be explained by an increased clearance of these substances, since the plasma creatinin concentration even decreased during the study. It is suggested that the physical stress tolerance was increased due to the training programme. Possible reasons for the discrepancy between the data of the present study and those found in other studies are the differences in amount and intensity of training, the carefully constructed training programme with a gradually undulating increase of distance and the fact that blood sampling before each contest was done after two days rest. In most other studies blood was generally sampled the day after physical exercise was stopped.

The basal concentration of the anabolic hormone testosterone increased only. in males in the course of the training (Fig. 4.2.2). These results are in accordance with those reported by Kuoppasalmi and Adlercreutz (38) and Remes et al. (46), who suggested that basal testosterone concentration will increase due to endurance training, which should be conslidered as a training adaptation. Remes (47) reported in another study that fit subjects tended to have after exercise a smaller decrease of plasma testosterone concentration and a smaller ratio of testosterone and sex hormone binding globulln than less fit subjects. The results of the afore mentioned studies are in disagreement with those of Hackney et al. (19) who reported a lower plasma testosterone concentration in endurance trained males ( $>5$ years) as compared to untrained males. There are several possibilities for thils disagreement. The study of Hackney et al. was not a longitudinal one and did not start with untrained subjects. Another reason may be the large interindividual varlation in testosterone concentration, which means that the Intervention of physical exercise is not necessarily the reason for the difference found between the trained and untrained group. Moreover the blood samples were taken after only one day rest and the training status or physical fitness was not described. After acute prolonged exercise plasma testosterone concentration is decreased (Fig. 4.2.2;13,37,38). The increase of the basal plasma testosterone concentration in the course of the training period thus suggests an increase of physical stress tolerance. This is supported by the finding that the same exercise stimulus caused a lower plasma concentration of the stress marker dehydroeplandrosterone-sulphate (DHEAS) in males and females (Fig. 4.2.4). After acute prolonged exercise the plasma DHEAs concentration is decreased. Keizer (34) aiso reported that basal DHEAS levels in females were significanty lower after training. However, Ronkainen et al. (51) found that the mean concentrations of cortisol and DHEAS did not differ significantly between runners and their controls. Long-term effects of regular training on the adrenal cortex of endurance runners have not been described. The response of DHEAS due to physical exercise 
thus seems to be dependent on several factors such as the amount of physical stress, the intensity of training and fitness of the individual.

Basal plasma activity of the muscle enzyme Asat and the liver enzyme Alat decreased with increased training load during the study (Table 5.3.1), which has not been found before. This indicates an increase or at least a maintenance of muscle integrity. Additional to the decrease of plasma activity of Asat and Alat, a decrease in $t_{1 / 2}$ of CK was found (Table 5.3.3). Rogers et al. (50) found a tw, of CK after a marathon of about $30 \mathrm{~h}$ for males and females. The larger value found in the mentioned study as compared to the present results may be explained by a renewed leakage of muscle enzymes in blood due to physical exercise after the marathon in the study of Rogers et al. $(29,31)$. In the present study the volunteers rested for 3 days after the marathon. This decrease in $t_{1 / 2}$ of $\mathrm{CK}$ from $21 \mathrm{~h}$ to $13 \mathrm{~h}$ suggests an increase of the clearance rate as a result of an increased liver function or liver blood flow associated with training. The increased disappearance rate of CK from plasma may have consequences for diagnostic purposes. Because the $t_{w}$ of CK shows a $26 \%$ decrease after 18-20 months training, plasma muscle enzyme activity as a parameter for damaged muscle tissue should be considered in relation to training status including the time which has been devoted to training.

An adaptation to training was also demonstrated by the increased concentration in muscle tissue of compounds which are related to the energy status of muscle tissue, in particular CP, ATP and glycogen (Table 5.1.2 to 5.1.4). The increase in tissue levels of ATP is in line with observations made by Karlsson et al. (32), MacDougall et al. (40), and Eriksson et al. (16). Conflicting results have been published regarding the effect on creatine phosphate levels. MacDougall et al. (40) found about a $3 \%$ increase in $\mathrm{m}$. triceps brachil caused by heavy resistance training. In contrast, Karlsson et al. (32) could not observe any effect of physical training on the content of this high-energy phosphate in $\mathrm{m}$. quadriceps. Our observations corroborate the findings of the former investigators. An increase of muscle glycogen content after a training period is generally accepted (7). It is also generally accepted that the training stimulus should be of a high intensity to reach an increase of concentration of energy rich substrates (1). These increases may be related to an increased number of mitochondria (59). Thus an increase of CP, ATP and glycogen after a 6 months' training programme based on enlarging the endurance capacity in stead of the intensity of the training is remarkable and has not been reported before.

As to the morphology of muscle tissue, during the training period an increase of histological abnormalities in muscle tissue (central nuclei, infiltration of macrophages, myoblastic activity and regeneration) was found correlating with the increase of the distance covered. However, the muscle damage and frequency of muscle damage were much smaller than those reported by Hikida et al. (26) and Warhol et al. (60). These differences may be attributed to the way of training or the distances covered (volume of training). It may be 
that Hikida et al. did not employ such a carefully constructed training programme as used in the present study. Since exact data about these determinants of training are lacking in literature, it is difficult to compare our results with those of other studies.

The results of the present study clearly show that endurance training has effects on hematological variables. The number of erythrocytes decreased significantly in the course of the training programme. After the marathon a further decrease in number of erythocytes was seen. $\mathrm{Hb}, \mathrm{Ht}$ and ferritin levels also decreased (Table 6.1.1 to 6.1.4). However, the values remained within the normal range and are comparable with the results reported by several other investigators $(9,15,27,62,63)$.

The variation in erythrocyte diameter significantly increased before the marathon as compared to the values before and after the 15 and $25 \mathrm{~km}$ contest (Table 6.1.2 and Table 6.1.4). This may be caused by fragmentation and inhomogeneous cell' size. Fragmentation may be caused by the increase of training volume and accompanying repeated foot strikes, especially during the last 6 weeks before the marathon and the marathon itself (Fig. 2.3.). This may elicit hemolysis due to mechanical trauma to red blood cells occurring at toot strike which is supported by Miller (43).

Endurance training also has effects on platelets. During training the larger platelets, which are considered to be the most active in the coagulation process, disappear (Table 6.1.1 and Table 6.3.3). There is also a significant decrease in platelet numbers and of the plateletcrit, which has not been reported before. Physiological implications of these findings are that intravascular blood coagulation may be decreased in endurance trained people. Drygas (12) reported that after acute prolonged exercise platelet count increases. We also found a moderate increase In platelet count after the 25 and $42 \mathrm{~km}$ contest, although the number of platelets remained significantly lower than the starting values. Thus. endurance training may result in a decrease of platelet induced coagulation. However, after an acute bout of maximal exercise or prolonged endurance exercise a transient slight increase can be found. In a review article Rudmann (52) reported a number of effects of physical exercise on hematological parameters. He concludes that the effects observed until now are not consistent and he recommends continued research under standardized clrcumstances.

The white blood cells demonstrate a shift to a more homogeneous composition of the neutrophils during the training period. It is speculated that a younger and more homogeneous white cell population can react in a more alert way. The effects on the white cells developed during the training period for the $25 \mathrm{~km}$ contest; they stabilized during the last period. It is suggested that endurance training with running distances of $35-70 \mathrm{~km}$ per week as described in this study has positive aspects with respect to the white blood cell population.

Summary of training effects

- After 6 months training there is no Increase in maximal speed, but there is an Increase of endurance capacity and a larger maximal work load can be performed. 
- The basal plasma concentrations of urea, creatinin, uric acid and albumin remain constant or decrease; basal plasma testosterone concentration increases, basal plasma cortisol concentration remains constant and basal plasma DHEAS concentration decreases. These observations suggest an increased stress tolerance.

- Basal plasma activity of Alat and Asat decreases and the basal plasma activity of CK remains constant. These flndlings suggest an increase in metabolic clearance and in muscle integrity. Besides there was an increase of energy rich compounds in muscle tissue. - The number of red cells decreased due to the training period, particularly due to the training before the marathon and running the marathon; $\mathrm{Hb}, \mathrm{Ht}$ and ferritin also decreased. However, all values remained within the normal range. There was a decrease in the number of platelets and of plateletcrit during the training period and the more active ones disappeared from the circulation. Moreover, the population of neutrophils became more homogeneous in the course of the training.

- There was only a minor increase of muscle damage in relation to the distance covered. However, muscle damage was small as compared to results reported by other investigators.

We may conclude that a training programme as described has positive aspects with respect to endurance capacity, metabolic stress tolerance and hematological parameters with the exception of the red cell system during the tralning perlod before the marathon. There was only minor muscle tissue damage.

\section{Effects of the contests}

The mean running time of the volunteers In the marathon was in males $3 \mathrm{~h} 42 \mathrm{~min}$ and in females $4 \mathrm{~h} 00 \mathrm{~min}$ (Table 3.2). The performance capacity (the pre-contest treadmill speed at lactate concentration of $4 \mathrm{mmol. \textrm {I } ^ { - 1 } )}$ was in males $3.85 \mathrm{m.s}^{-1}$ and in females $3.47 \mathrm{~m} \cdot \mathrm{s}^{-1}$ (Table 3.3). The performance capaclty of the particlpants of the present study is comparable to the corresponding value of $4.04 \mathrm{m.s}^{-1}$ of a group marathon runners with running time $>3: 00 \mathrm{~h}$ as reported by Sjödín and Svedenhag (55).

The present study demonstrates that contests have effects on body. homeostasis and physical working capacity as measured In exercise tests and other varlables. The effects of the contests are related to the distance covered. It was demonstrated that the decrease in test performance was related to the distance covered in the preceding contest (Table 3.5). Also the number of subjects with a reduced performance 3 days after the contest increased with the contest distance (Table 3.6).

The effect of the contests was reflected in an Increase of plasma urea and creatinin concentration (Table 4.1.1), an increase of plasma CK and Asat activity (Table 5.3.1), a decrease in testosterone concentration, an increase of DHEAS concentration (Table 4.2.1) and a decrease of muscle glycogen content (Table 5.1.5).

The plasma concentrations of the metabolites urea and creatinin can be used as parameters for the endurance exercise load whilch is 
In agreement with data in literature $(20,61)$. The uric acid concentration is not useful as parameter for physical stress due to endurance exercise, as there were no differences in the responses after the three contests and hardly any differences between the effects of the contests and the exercise tests on uric acid (Table 4.1.1). This is in agreement with the study of Green et al. (18), who concluded that exercise intensity rather than total work output is a critical factor mediating increases in plasma uric acid concentration. These results are consistent with the interpretation that uric acid formation may arise from purine nucleotide degradation especially when fast-twitch fibers are involved during exercise demanding high energy. In supra-maximal exercise, reductions of $30-40 \%$ in muscle ATP concentration have been reported (56). Decreases in ATP and in total adenine nucleotides are accompanied by increases in inosine-5'monophosphate (IMP) (53). Green et al. (18) hypothesized that intermittently performed prolonged supra-maximal exercise would induce a substantial increase in IMP formation and degradation, thereby producing progressive elevation of the blood levels of uric acid.

Testosterone and DHEAS concentrations demonstrated a significant relationship with physical stress. With increasing contest distance a decrease in testosterone and an increase in DHEAS concentration was found (Table 4.2.1.). The increased DHEAS concentration was not statistically significant, problably due to the large variation in the measured values. In general, the responses of the hormone concentrations (testosterone, cortisol and DHEAS) during the test protocol were similar in males and females. These observations are in agreement with the results of Urhausen et al. (58).

Plasma activities of CK and Asat 14-16 $\mathrm{h}$ after the contests demonstrated increases of 248,411 and 1352 U.1-1 for males and 200,293 and $700 \mathrm{U} . \mathrm{I}^{-1}$ for females respectively, which is similar to results obtained in other studles $(2,3,8,17,22,29,31,41,44,48)$.

Supposing that the total enzyme content of damaged muscle fibers enters the extra-cellular fluid, the callculated muscle damage amounts to $0.006-0.022 \%$ of the total muscle mass in males and females, respectively (Table 5.3.6). It is hard to envision that such a small percentage of damaged skeletal muscle tissue would have a large influence on test performance. Nevertheless, after the marathon there was a statistically signiflcant negative relationship between the test performance and the amount of damaged muscle tissue in males (M) and females (F) (M:r $=-0.38$ and $p=0.041$, $F: r=-0.48$ and $p=0.047$ ). The fact that muscle damage had only $a$ direct influence on test performance after the marathon and not after the other two contests suggests that not only the physical stress at the muscle cell is responsible for performance decrease, but that the other described factors may be important as well.

Plasma activity increases of CK and Asat and the large spread in CK and Asat plasma activities after the various contests have also been demonstrated in other studies $(41,44,48)$. The large spread in the increase of plasma activities of CK and Asat after the contests cannot be explained by the impact factor of running, because the training programme of the participants was similar and their training 
status comparable at the start of the study. This suggests that the increase of $\mathrm{CK}$ and Asat plasma activity does not only depend on factors such as training distance and intensity, running surface and running shoes, but also depends on the individual properties of the muscle fibers which is indicated by the observation that there were subjects who had a lower CK and Asat plasma activity after the marathon than other subjects had after the $15 \mathrm{~km}$ contest.

The increase of plasma activity of CK and Asat seems to be gender related. Concerning this difference, it was remarkable that in females there was a significant positive correlation between the calculated damaged muscle mass (based on the cumulative enzyme release and enzyme content) and the concentration of testosterone 14-16 hours after all contests (p. 112). In males there was a trend to a significant positive relationship between these varlables after the marathon only. The calculated damaged muscle mass is based on muscie CK content and the cumulative CK release. It has been demonstrated that gender hormones may influence enzyme release from muscle tissue (36). Testosterone seems to promote enzyme release, while oestrogens have an inhibitory effect (57). Our data are in agreement with these findings, since females with higher testosterone concentration demonstrate the highest calculated muscle damage. This correlation suggests that the testosterone concentration is related to the degree of muscle damage.

From muscle pathology it is well established that most metabolic myopathies result early in energy crisis (44), which means that the energy rich compounds cannot meet the muscle demands. This may elicit muscle damage and rhabdomyolysis (44). It can be hypothesized that a relationship exists between energy crisis and muscle damage. In the present study no energy crisis was found when looking at the energy rich substrates in muscle tissue (pp. 85-86). In addition no severe glycogen depletion was found. Neverthelless it is concelvable that individual fibers did encounter energy crisis. This is supported by observations from PAS stained sections showing glycogen depletion in type I, IIA and IIb fibers (p. 92). However, the amount of damage, which was minimal when compared with results of other studies, was too small to study the relationship between glycogen depletion in single fibers and damage $(26,28,60)$. Arguments in favour of energy crisis as an important factor for damaging muscle fibers are the increase of the minor histologicall changes with the distance covered and a positive significant correlation between the test performance after the marathon and the CP concentration in the blopsy taken 0.5-6 $\mathrm{h}$ after the marathon. There are also data, which demonstrate that above a certain threshold in physical stress there is an exponentional increase of CK and Asat activity in plasma $(29,31)$.

\section{Recovery}

An estimation of recovery time and degree of recovery after prolonged exercise is important for the timing and the right amount of training which is necessary to build up a further increase or 
maintenance of physical stress tolerance. In this study, performance, plasma lactate concentration and heart rate in maximal exercise tests 3 and 5 days after each contest were used to get information about the course of the recovery processes. Moreover during these periods a number of variables were determined to give information about the course of recovery processes such as changes in catabolism and anabolism (plasma urea, creatinin, uric acid, albumin, cortisol, testosterone and DHEAS concentrations), changes in skeletal muscle bilochemistry (plasma muscle enzyme activity and muscle tissue content of energy rich substrates) and changes in muscle

morphology. From literature no comparable data are available of studies in which recovery was studied by comparing the performance in tests before and after contests.

It was demonstrated that there was a decrease in test performance after the contests which was related to the distance covered in the preceding contest. Firstly the test-performance was lower with longer contest distance, which indicates a delayed recovery with lincreasing length of the run, (Table 3.3 to 3.5 ). Secondly the number of subjects with a reduced performance 3 days after the contest increased with the contest distance (Table 3.6). The delay of recovery was not reflected in differences between plasma lactate concentration and heart rate during the exercise tests before and after the contests (Table 3.3). It was expected that the maximal plasma lactate concentration would be increased during the first exercise test after the contest and to a lesser extent also in the second one, because in a fatiqued situation more motorunits have to be recruited to perform a similar degree of exercise $(29,31,42)$. The fact that we did not find this is most probably due to the large inter-individual variation in lactate concentration and heart rate. Another explanation may be the large variation of day to day performance as documented by Kuipers (35).

After each contest there was a clear increase of urea and creatinin plasma concentration in both males and females (Table 4.1.1), which is comparable with data from literature $(5,21,39,45,54)$. During the recovery period, there was a remarkable gender difference with respect to the return to the basal level of urea concentration after the marathon, although there were no gender differences in the increases of urea and creatinin concentrations 4-6 $\mathrm{h}$ after the contests. In males the return to basal level was much slower than in females (Fig. 4.1.2). After each contest there was also a decrease of albumin concentration (Table 4.1.2), which is in agreement with findings of Dohm et al. (10). The correlation between the decreased albumin concentration and the persisting increased urea concentration after the marathon in males, suggests a prolonged catabollc status which was not found In females. The data support the observations of Cerny (5) who suggested an increased protein degradation, contributing to energy production during prolonged endurance exercise (5). Dohm et al. (10) also reported that protein degradation during endurance exercise and recovery may lead to a decrease of albumin concentration during recovery. These data suggest that after the marathon a catabolic status persists longer in males than in females. As the catabolic status immediately after the 
marathon is similar in males and females, the longer persisting catabolic status in males during recovery may be explained by a difference in the anabolic response between males and females. Arguments for this explanation are the observed time-concentration courses of cortisol, DHEAS and testosterone. In males and femalles the stress hormones cortisol and DHEAS show a similar response after endurance exercise (Fig. 4.2.3 and 4.2.4) indicating that there is no gender difference with respect to physical stress. The concentration time-course of the anabolic hormone testosterone, however, shows a large decrease after prolonged endurance exercise in males also found by Dufaux et al. $(13,14)$, Kuoppasalmil et all. $(37,38)$ and Janssen et al. $(30)$, while in females this decrease is minor (Fig. 4.2.2). Moreover, in males the increase of testosterone concentration during recovery is a much slower process than in females, which may lead to the observed slower recovery from the catabolic status in males.

Another aspect of recovery is the deplletion and resynthesis of energy substrates in muscle tissue. Although there was a clear decrease of muscle glycogen content after all contests, even after the marathon there was no severe depletion of muscle glycogen (Table 5.1.6). A comparison of glycogen content in muscle biopsies taken $35 \pm 8$ min after the marathon $\left(136 \pm 36 \mu \mathrm{mol}^{-g^{-1}}\right.$ dry weight) with muscle biopsies taken between 4 and $6 \mathrm{~h}$ after the marathon $\left(189 \pm 49 \mu\right.$ mol.g $\left.\mathrm{g}^{-1} \mathrm{dw}\right)$ shows a resynthesis of glycogen immediately after the contest.

The fact that no severe muscle glycogen depletion occurs even after running a marathon indicates that the total amount of muscle glycogen is not the only limiting factor for endurance performance in recreative runners. In PAS stained sections of muscle tissue we observed locally severe glycogen depletion. Although there was not a severe mean glycogen depletion it cannot be excluded that local glycogen depletion can be a limiting factor for the performance of single muscle fibers. Severe muscle glycogen depletion (40-70 $\mu$ mol.g-7 $\mathrm{dw}$ ) in well trained athletes and in bycicle ergometer tests was found by Costill et al. and by Keizer et al. $(7,33)$. Keizer reported that after severe depletion $\left(70 \pm 40 \mu \mathrm{mol} . \mathrm{g}^{-1} \mathrm{dw}\right)$ due to exercise on a bycicle ergometer, muscle glycogen returned to $208 \pm 32$ $\mu$ mol.g ( $^{-1}(60 \%$ of the starting values) after $5 \mathrm{~h}$ and that after $22 \mathrm{~h}$ muscle glycogen content had returned to basic levels. One day later, however, the performance was significantly lower than before. This lower performance indicates that a normal muscle glycogen is not the only factor which determines performance.

The muscle glycogen levels measured one week after the contests demonstrate that there was a difference in resynthesis of glycogen, depending on the distance of the contest. The difference in resynthesis of glycogen may be caused by the degree of damage of the muscle fiber because more time is required to restore glycogen levels to pre-contest values when the muscle is damaged ( 4 and unpublished. results). Keizer et al. (33) found after a bicycle ergometer test a musclle glycogen resynthesis of $25 \mu \mathrm{mol} \cdot \mathrm{g}^{-1} \cdot \mathrm{h}^{-1}$ during the first $5 \mathrm{~h}$. After the marathon we found a glycogen resynthesis of $10-15 \mu \mathrm{mol} \cdot \mathrm{g}^{-11} \cdot \mathrm{h}^{-1}$. As it is generally accepted that in cycling muscle damage does not occur, these data Indlicate that glycogen resynthesis is related to muscle damage. 
Indicators for delayed recovery

Performance expressed as ratio of maximal running speed in treadimill or field tests 3 and 5 days after each contest, and the maximal running speed in a treadmill or field test 3 days before each contest may be considered a measure for recovery. The group with a ratlo equal or greater than 1 is assumed to be recovered more rapidly than the group with a ratio smaller than 1 . When the values of all variables studied in this thesis of these both groups were compared to each other, it appeared, for males and females, that there was no significant difference for any varlable. The analysis was carried out with the values of all variables determined before and after each contest. However, the values of the variables after the three contests demonstrate significant differences as described in Chapter 3-5. From these observations, it may be concluded that changes in one single variable are not indicative for recovery, although the changes in variables such as Asat and $C K$ activity, urea, creatinin, testosterone and DHEAS concentration and contest speed differentiate between the physical stress of the several contests. This is most probably caused by the fact that the effect of the contests on these variables show large inter-individual variations. Thus it may be expected that a proper combination of varlables will indeed have predictive value for the degree of recovery. Therefore the construction of a mathematical model to predict recovery using a combination of variables such as intensity of running, percentage of maximal heart rate during the contest, performance, urea, creatinin, albumin, Asat, CK, Alat, cortisol, testosterone and DHEAS concentration, estimated at several moments after the three contests, will be subject of further study. In summary we come to the following conclusions.

- The test performance 3 days after a contest is negatively related to the distance of the contest. The test performance 5 days after a contest is not different from the test performance before a contest.

- The time concentration course of plasma lactate during an exercise test after a contest does not give information about the degree of recovery.

- After a marathon the catabolic status persists longer in males than in females.

- The speed of resynthesis of muscle glycogen is positively related to the degree of muscle damage.

\section{Final remarks}

The dramatical increase of the popularity of marathon running during the last decadies often raises the question whether running such a large distance in a relatively short time is healthy for, or to the contrary, has adverse effects on the human organism. This study does not give the ultimate answer to this question. However, most of the data presented in this thesis, indicate that a carefully built up and well conducted training programme has positive effects with 
respect to endurance capacity, metabolic stress tolerance and a number of hematological parameters. Muscle damage, which has raised a lot of discussion during the last few years, was minimal and most probably not of relevance with respect to the health status of the participants.

Nevertheless, there are some adverse aspects in marathon running. A number of people want to run a marathon whille they are not suited to run at all, or try to run at a speed which does not fit their age or physical abilities. Thus injuries will occur when large groups of people start tralining for a marathon, the more so when training is not conducted or conducted by unexperienced coaches. This implicates that the number of training sessions and the diversity of training should have an individual basis, so that the time for recovery for each person is sufficient which may also lead to a lower risk for injuries.

Apart from positive and adverse physiological aspects of marathon running, one should bear in mind that mental aspects are important as well. Our group of volunteers experienced the training programme and running the contests including the marathon as valuable and rewarding, even when there were injurles or other disadvantages. In our opinion training for a marathon is an experience in which positive aspects overrule the negative ones for those who are motivated from the start of the training until the finish of the race.

We therefore fully agree with a (sllightly modified) note of Maron and Horvath made in their classical review of the marathon Iiterature (41).

It is of interest to note that the question repeatedly asked by the early investigators regarding the possible pathological repercussions of marathon running to the human body, has now been completely reversed to the question: does the training required for the marathon in some way protect the individual against disease?

To answer thils question a lot of research still has to be done.

\section{References}

1 Astrand P.O., and Rodahl K.: Physical training (chapter 10) in: Textbook of work physiology. Physiological bases of exercise. third edition. McGraw-Hill Book Company, 1986.

2 Berg A., Haralambie G.: Changes in serum creatlne kinase and hexose phosphate isomerase activity with exercise duration. Eur J Appl Physiol 39:191-201,1978.

3 Berg A., Keul J.: Serum enzyme kinetics during and after intensive long term stress. Dtsch Zeit Sportmed 1:12-17,1982.

4 Blom Per C.S., Costill D.L., and Völlestad N.K.: Exhaustive running: Inappropriate as a stimulus of muscle glycogen super compensation. Med Sci Sport Exer 19(4):398-403,1987.

5 Cerny F.: Protein metabolism during two hour ergometer exercise. Proceedings of the second international symposium on biochemistry of exercise Magglingen. Howald $H$. and Poortmans J.R. (ed), Birkhäuser Verlag Basel. 1973, pp 232-237. 
6 Costill D.L., Maglisho E.W., Fitts R.,Morgan W., Wilmore J., and Kuipers $H_{2}$ : Overtraining: physicall and psychological effects of a sudden increase in training. Med Scl Sports Exerc (abstract) 19(2): $\$ 77,1987$.

7 Costill D.L.: Carbohydrates for exercise: Dietary demands for optimall performance. Int J Sports Med 9:1-18,1988.

8 Diamond Th., Smith R., Goldman A.D., and Myburgh D.D.M.: The dilemma of the creatine kinase (CK-MB) in marathon runners. S Afr Med J 63:37-41,1983.

9 Dickson D.N., Wilkinson R.L.,Noakes T.D.: Effects of ultramarathon training and racing on haematolocil parameter and serum ferritin levels in well trained athletes. Int $\mathbf{J}$ Sports Med $3: 111-117,1982$.

10 Dohm G.L., Tapscott E.B., and Kasperek G.J.: Protein degradation during endurance exercise and recovery. Med Sci Sports Exer 19(5):s166-s171.

11 Drucker W.D., David R.R.: Dehydroeplandrosterone sulfate (DHEAS) in normals and patients with hyperprolactinemia, in Genazzi A.R., Thijssen J.H.H., Silteri P.K. (eds): Adrenal androgens, Raven Press, New York, U.S.A., pp 89-94, 1980.

12 Drygas W.K.: Changes in blood platelet function, coagulation, and fibrinolytic activity in response to moderate, exhaustive and prolonged exercise. Int $J$ Sports Med 9:67-72,1988.

13 Dufaux B., Assmann G., Order U., Holdierath A., Hollmann W.: Plasma lipoproteins, hormones, and energy substrates during the first days after prolonged exercise. Int J Sports Med 2: 256-260,1981.

14 Dufaux B., Hoederath A., Heck H., Hollmann W.: Serum testosterone levels during the first hours and days after a prolonged physical exercise and the influence of physical training. Fourth Int Symp Biochem Exerc, abstract 47, Brussels, 1979

15 Dufaux B., Hoederath A., Streiltberger I., Hollmann W., Assmann G.: Serum ferritin, transferrin, haptoglobin and iron in middle and long-distance runners, elite rowers and professional racing cyclists. Int $J$ Sports Med 2:43-46,1981.

16 Eriksson B.O., Gollnick P.D., and Saltin B.: Muscle metabolism and enzyme activities after training in boys 11-13 years old. Acta Physiol Scand 87:485-497,1973.

17 Frledel R., Mattenheimer H.: The felgned release of cell enzymes, distribution and transport of cell enzymes within the extra cellular space. J Clin Chem Clin Biochem 14:109$117,1976$.

18 Green H.J., and Fraser I.G.:Differential effects of exercise intensity on serum uric acid concentration. Med Scil Sports Exerc 20(1):55-59.1988.

19 Hackney A.C., Sinning W.E., and B.C.Bruot: Reproductive hormonal profiles of endurance-trained and untrained males. Med Scil Sports Exerc 20(1):60-65,1988.

20 Haralambie G., Senser L.: Metabolic changes in man during long-distance swimming. Eur J Appl Physiol 43:115-125,1980.

21 Haralambie G., and Berg A,: Serum urea and amino nitrogen changes with exercise duration. Eur $J$ Appl Physiol 36:39-48, 1976. 
22 Haralamble G., Senser L.: Metabolic changes in man during long-distance swimming. Eur J Appl Physiol 43:115-125,1980.

23 Haralambie G., Senser L., Sierra-Chavez R.." Physiological and metabolic effects of a $25 \mathrm{~km}$ race in female athletes. Eur J Appl Physiol 47:123-131,1981.

24 Heck H., Mader A., Hess G., Mücke S., Müller R., and Hollmann W.: Justification of the 4-mmol/l lactate threshold. Int $J$ Sports Med 6:117-130,1985.

25 Hickson P.C., Hagberg J.M., Ehsani, A.A. and Holloszy J.O.: Time course of the adaptive responses of aerobic power and heart rate to trailning. Med Sci Sports Exerc 13(1):17-20,1981

26 Hikida R.S., Staron R.S., Hagerman F.C., Sherman W.H., Costill D.L.: Muscle fiber necrosis associated with human marathon runners. J Neurol Sci 59:185-203,1983.

27 Hoepelman. Blloedarmoede door sportbeoefening: een onschuldige bijwerking van een gezonde hobby. NTvG pp 155-157,1986.

28 Hoppeler $H$.: Exercise-induced ultrastructural changes in skeletal muscle. Int $J$ Sport Med 7:187-204,1986.

29 Janssen G.M.E., Kuipers H., Keizer H., Verstappen F.: Plasma enzyme activities and running performance in a maximal treadmill test before and after a $30 \mathrm{~km}$ race or a marathon. Int J Sports Med 5(suppl):98-99,1984.

30 Janssen G.M.E., Kuipers H., Keizer H.: Plasma CPK and AST activity, and plasma testosterone after $200 \mathrm{~km}$ speed skating. Med Sci Sport Exer 18 (suppl):205,1986.

31 Janssen G.M.E., Kuipers H., Keizer H.A., Geurten P., Kranenburg van G., and Does R.J.M.M.: Splerbeschadiging, prestatievermogen en herstel na verschillende soorten wegwedstrijden. Gen en Sport 20(5):190-195,1987.

32 Karisson J., Nordesjoe L.O., Jorteldt L., and Saltín B.: Muscle lactate, ATP, and CP levels during excercise after physical training in man. J Appl Physiol 33:199-203,1972.

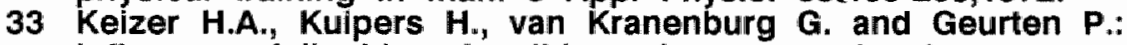
Influence of liquid and solid meals on muscie glycogen resynthesis, plasma fuel hormone response, and maximall physical working capacity. Int J Sports Med 8:99-104,1986.

34 Kelzer H.A., Kuipers H., de Haan J., Janssen G.M.E., Beckers E., Habets L., van Kranenburg $G_{\text {., }}$ and Geurten P.: Effect of a 3-month endurance training program on metabollc and multiple hormonal responses to exercise. Int $J$ Sports Med 8:154-160, 1987.

35 Kuipers H.: Ph.D. thesis.: Varlability of physiological responses to exerclise. Uitgeverij de Vrieseborch Haarlem, 1983.

36 Kuipers $H$, Keizer $H$.: Overtraining in elite ahtlete. Accepted $J$ Sports Med 1988.

37 Kuoppasalmi K., Naneri H., Harkonen M., Adlercreutz H.: Plasma cortisol, androstenedione, testosterone and luteinizing hormone in running exercise of different intensities. J Clin Lab Invest 40:403-409,1980.

38 Kuoppasalmi K., Adlercreutz H.: Interaction between catabolic and anabolic steroid hormones in muscular exercise, in Fotherby K. Pal S.B. (eds): Exercise endocrinology. W. de Gruyter, Berlin, 1985, pp 65-156. 
39 Lorenz R., und Gerber G.: Harnstoff bel körperlichen Belastungen: Veränderungen der Synthese, der Blutkonzentration und der Ausscheidung. Med u Sport 19:240-247,1979.

40 MacDougall J.D., Ward G.R., Salle D.G., Sutton J.R.: Blochemical adaptation of human skeletal muscle to heavy resistance trailning and immobilization. $J$ Appl Physiol 43:700-703,1977.

41 Maron M.B., Horvath S.M.: The marathon: a history and review of the literature. Med Sci in Sports 10(2):137-150,1978.

42 Mellerowicz H., and Barron D.K.: Overtraining. In Larson and Leonard (eds) Encyclopedia of sport sciences and medicine. pp 1310-1312, MacMillan, New York, 1971.

43 Miller B.J., Pate R.R., and Burgess W.: Foot impact force and intravascular hemolysis during distance running. Int $\mathbf{J}$ Sports Med 9:56-60,1988.

44 Noakes T.D.: Effects of exercise on serum enzyme activities in humans. Sports Med 4:245-267,1987

45 Refsum H.E., and Strömme S.B.: Urea and creatinine production and excretion in urine during and after prolonged heavy exercise. Scand $\mathbf{J}$ Clin Lab Invest 33:247-254,1974.

46 Remes K., Kuoppasalmi K., Adlercreutz H.: Effect of Long-term physical training on plasma testosterone, androstenedione, luteinizing hormone and sex-hormone binding capacity. Scan J Clin Lab Invest 39:743-749,1979.

47 Remes K., Kuoppasalmi $K$ and Adlercreutz $H_{\text {.: }}$ Effect of Physical exercise and sleep deprivation on plasam androgen levels: modifying effect of physical fitness. Int J Sports Med 6:131-135,1985.

48 Rilley W.J., Pyke F.S., Roberts A.D., and England J.F.: The effect of long-distance running on some biochemical variables. Clin Chim Acta 65:83-89,1975.

49 Pöcker L., Kirsch K.A. and Stoboy H.: Plasma volume, albumin and globulin concentrations and their intravascular masses. Europ J Appl Physiol 36,57-64,1976.

50 Rogers M.A., Stull G.A., and Apple F.S.: Creatine kinase isoenzyme activities in men and women following a marathon race. Med Scl Sport Exer 17(6):679-682,1985.

51 Ronkainen H.R.A., Parkarinen A.J.s and Kaupila A.J.I.: Adrenocorticol function of female endurance runners and Joggers. Med Scl Sports Exerc 18(4):385-389,1986.

52 Rudmann S.V.: The effects of exercise on hemostasis: A review of the literature and implications for research. $J$ Med Technol 4/5:215-217, 1987.

53 Sahlin K., Palmskog $G_{*}$, and Hultman E.: Adenine nucleotide and IMP contents of the quadriceps muscle in man after exercise. Ptlügers Arch 374:193-198,1978.

54 Schuster von H.G. Neumann G., und Buhl H.: Kreatinin- und Kreatinverânderungen Im Blut bei Körperlicher Belastung. Med Sport 19(8):235-240,1979.

55 Sjödin B., and Svedenhag J.: Applled physiology of marathon running. Sports Med 2:83-99,1985.

56 Sutton J.R., Toews C.J., Ward G.R., and Fox L.H..: Purine metabolism during strenous muscular exercise in man. Metabolism 29:254-259,1980. 
57 Thomson W.H.S., and Smith I.: Effects of oestrogen on erythrocyte enzyme efflux in normal men and women. Clin Chim Acta 103:203-208,1980.

58 Urhausen A., Kullmer T., and Kindermann W.: A 7-week follow up study of the behaviour of testosterone and cortisol during the competition period in rowers. Eur $\mathrm{J}$ Appl Physiol $56: 528-533,1987$.

59 Viru A: the mechanism of training effects: a hypothesis. Int J Sport Med 5:219-227,1984.

60 Warhol M.J., Siegel A.J., Evans W.J., Silverman L.M.: Skeletal muscle injury and repair in marathon runners after competition. Am J Pathol 118:331-339,1985.

61 Whiting P.H., Maughan R.J., and Miller J.D.B.: Dehydration and serum biochemical changes in marathon runners. Eur $J$ Appl Physiol 52:183-187,1984.

62 Wishnitzer R., Vorst E., Berrebl A.: Bone marrow iron depression in competitive distance runners. Int $\mathbf{J}$ Sports Med 4:27-30,1983.

63 Yoshimura. H.: Anemia during physical training; sports anemia. Nutrition Reviews 28:251-253,1970 


\section{Samenvatting}

Presteren is een woord dat in de topsport vaak synoniem is met winnen. Vele trainingen zijn nodig om over de juiste vorm te beschikken op het moment dat gepresteerd moet worden. Zeker in een Jaar dat de olympische spelen plaatsvinden worden termen als belasting en belastbaarheid veelvuldig gebruikt, vaak in samenhang met woorden als trainingseenheid, herstel of herstelperiode. Als gevolg van een sterke groel naar een actievere leefstijl in de laatste decennila komen de aanvankelijk typische problemen van de wedstrijdsporter ook voor bij de groelende groep recreatieve sporters.

Het doel van dit onderzoek was het bestuderen van de belasting in relatie tot belastbaarheld aan de hand van het verloop van een aantal blochemische en fysiologische processen. De daarbij beschouwde fenomenen kunnen in vier categorieën worden ingedeeld.

- Effecten op het prestatievermogen door duurtraining en wedstrijd.

- Katabole en anabole veranderingen in relatie tot langdurige inspanning.

- Blochemische en morfologische veranderingen van de skeletspier in relatie tot langdurige inspanning.

- Hematologische veranderingen na duurtraining.

Het longitudinale onderzoek duurde 20 maanden met drie testperioden rondom wedstrijden van 15, 25 en $42 \mathrm{~km}$. Elke testperlode, die twee weken duurde, bestond uit een inspanningstest drie dagen vóór, en twee Inspanningstesten drie, respectievelijk vijf, dagen na elke wedstrijd. Bovendien werden voor en na de wedstrijden

bloedmonsters afgenomen en werden drie spierbiopsleën uitgevoerd (6 dagen voor, 4-6 uur en 8 dagen na de wedstrijd). De resultaten van de metlingen werden paarsgewiljs vergeleken, zowel binnen als tussen de testperioden.

Aan het onderzoek namen 83 mannen en 31 vrouwen deel. Eind oktober 1984 werd gestart. $\mathrm{Na} \mathrm{5-6}$ maanden werd ter afsluiting van periode 1 de eerste wedstrijd (15 km) gelopen door 76 mannen en 26 vrouwen. De $25 \mathrm{~km}$ wedstrijd, die als eindpunt van periode 2 gold, vond 11-12 maanden na het begin van het onderzoek plaats; 72 mannen en 24 vrouwen haalden de eindstreep van dile wedstrijd. De marathon werd gelopen in de periode van maart tot en met juni 1986. Het aantal proefpersonen dat deze afstand aflegde was in totaal 78 (68\% van de oorspronkelljke 114 proefpersonen) waarvan 60 $(72 \%)$ mannen en $18(58 \%)$ vrouwen.

In hoofdstuk 3 wordt een aantal aspecten betreffende het prestatievermogen en het cardlo-respiratore systeem beschreven. Het maximale vermogen, bepaald met behulp van een fletsergometer, nam gedurende de trainingsperiode van 18-20 maanden bij de mannen met gemiddeld 33 watt $(12,4 \% ; p=0.0001)$ en bl] de vrouwen met 
gemiddeld 17 Watt $(8,9 \% ; p=0.0076)$ toe. De snelheld, gemeten tijdens loopbandtests, waarbij een plasma lactaatconcentratie van $4 \mathrm{mmol} . \mathrm{I}^{-1}$ werd bereikt nam in de loop van het onderzoek toe met $0.31 \mathrm{~m} . \mathrm{s}^{-11}$ bij de mannen en $0.29 \mathrm{~m} . \mathrm{s}^{-1}$ bij de vrouwen, terwijl een toename van de maximale snelheid niet kon worden aangetoond.

De testprestaties na de wedstrijden tonen aan dat de lengte van de periode die nodig is voor herstel sterk beinvloed wordt door de gelleverde inspanning tijdens de wedstrijd: niet alleen nam het aantal personen dat minder presteert tijdens een test na een langere wedstrijd toe in vergelijking met dit aantal na een kortere wedstrijd, ook het prestatieniveau vertoonde een daling.

Met behulp van de resultaten van de testprestatie vóor de wedstrijd was het mogelijk een voorspelling te doen betreffende de looptijd in de wedstrijden over 15, 25 en $42 \mathrm{~km}$. Beschouwen we de testresultaten voor en na de respectlevelljke wedstrijden, dan blijkt dat hun verhouding een maat voor herstel is.

In hoofdstuk 4 worden de veranderingen van katabolle en anabole variabelen tengevolge van langdurlge inspanning besproken.

De training had nauwelijks invloed op de ureum-, urinezuur-, albumine-, totaal eiwit-, cortisoll-, testosteron- en DHEAS-

concentraties in bloedplasma, maar veroorzaakte wel een dalling van de plasmaconcentratie van creatinine. Daarentegen traden na de wedstrijden wel zeer duidelijke veranderingen op in de plasmaconcentraties van de genoemde stoffen. Bovendlen waren de veranderingen afhankelijk van de lengte van de wedstrljd.

De marathon veroorzaakte bij mannen een langer durende katabole status dan bij vrouwen, hetgeen viel op te maken ult de langer durende verhoging van de plasmaconcentratie van ureum na de wedstrijd, hetgeen samenging met een sterkere dallng van de albumineconcentratie. Er zijn geen aanleidingen om te veronderstellen dat de nilerfunctle door het lopen van een marathon blijvend wordt beinvloed.

De toeneming in plasmaconcentratie van het bijnlerhormoon DHEAS bleek bij mannen en vrouwen een gelljkwaardlg gedrag te vertonen na fysieke inspanning. Daarentegen bleek dat bij mannen in tegenstelling tot bij vrouwen de lengte van de wedstrijd van invloed was op de daling van de testosteronconcentratle. Bl] grotere tysleke belasting duurde het langer voordat de testosteronconcentatle de ultgangswaarde weer berelkte.

In hoofdstuk 5 wordt aandacht besteed aan de energlehulshouding van de skeletspler (glycogeen, ATP, CP en andere nucleotiden), aan histologische veranderingen in de skeletspler en aan de mogelijkheid om splerbeschadiging vast te stellen en te kwantiflceren aan de hand van spierenzymactiviteiten in plasma.

Het bleek dat zelfs na een marathon de spler niet in een echte energlecrisis verkeert. Toch was er een signilicante correlatle tussen de prestatiedaling tljdens de inspanningstest 3 dagen na de marathon en de daling van de CP concentratie in de spler 0.5-6 uur na de marathon $(r=0.36, p=0.03)$. 
In spiercoupes was geen verschil aan te tonen tussen de verschillende typen spiervezels en glycogeendepletie enerzijds en spierweefselafwijkingen anderzijds. Wel namen soort en omvang van de afwijkingen toe met de lengte van training en wedstrijd. De afwljkingen in de splercoupes bleken geringer in omvang te zijn dan op grond van de huidige literatuur verwacht werd. Wanneer men ervan uitgaat dat de totalle enzyminhoud van de spiercel in de circulatie terecht komt is het berekende percentage beschadigd spierweefsel klein. Het was niet mogelijk om een siginificante relatie aan te tonen tussen de energetische toestand en de beschadiging in de spier enerzijds en de toeneming in de plasma-activiteit van de splerenzymen anderzljds. Ook was er geen verschill aan te tonen tussen soort en aantal afwijkingen in de $m$. gastrocnemius en de $m$. vastus lateralis.

De toeneming van en de spreiding in de spierenzymactiviteit in plasma na de drie wedstrijden waren gelijkwaardig met resultaten uit de literatuur. De gevonden verschillen en overeenkomsten in de bevindingen ten aanzien van de splerintegriteit suggeren dat de spier wellicht aok vila reversibele permeabiliteitsveranderingen lekkage van spierenzymen vertoont.

Ten aanzlen van het spierglycogeen bleek dat direct na het stoppen van de inspanning de resynthese begint. Verder bleek dat van een totale glycogeendepletie elgenlijk geen sprake is. Dit sluit niet uit dat de depletie van glycogeen van de gerecruteerde vezels wel een beperkende factor kan zljn. Prestatlebeperking moet dus meer op het niveau van recrutering worden gezocht.

De waargenomen supercompensatile van glycogeen een week na de 15 $\mathrm{km}$ wedstrijd zonder geconstateerde extra toevoer van koolhydraten maar wel met een tweetal korte inspanningstesten na de wedstrijd, kan van practisch belang zijn voor de wedstrijdsport. Een juiste planning van training en korte wedstrijden een week voor een marathon kunnen wellicht leiden tot overeenkomstige resultaten als die welke berelkt kunnen worden door extra toevoer van koolhydraten.

In hootdstuk 6 zijn een aantal veranderingen in hematologische variabellen als gevolg van training beschreven. Het doel van de bepalingen van de hematologische variabelen had een meer preventief karakter met betrekking tot een zich mogelljk ontwikkelende sportanemie.

De ferritineconcentratie van het bloedplasma bleek in de periode voor de $15 \mathrm{~km}$ wedstrijd sterk te dalen en zich vervolgens na de 15 $\mathrm{km}$ wedstrijd te stabiliseren. Ult de transversale benadering van de variabelen van het rode celsysteem bleek dat alle, soms statistisch signiflcante, veranderingen zich afspeelden binnen de klinisch aanvaarde normaalwaarden. Bij de longltudinale individuele benadering werden echter grotere verschillen aangetoond dan in het onderzoek van Costong et all.

Naast positieve aspecten werd ook een aantal negatieve aspecten gevonden zoals een dalling in het aantal erythrocyten, $\mathrm{Hb}$, $\mathrm{Ht}$ en ferritineconcentratie met de toename van de trainingsbelasting. Dit betekent dat het erythrocyensysteem zorgvuldig beoordeeld moet worden bij duursporters, zeker wanneer het om vrouwen gaat. Tot 
op zekere hoogte blijkt het lichaam zich celkinetisch aan te kunnen passen en op blochemisch niveau zall daardoor aanvankelijk niets merkbaar veranderen ( $\mathrm{Hb}, \mathrm{MCH}$ en $\mathrm{MCHC}$ ).

In het algemeen blijkt dat duurtraining een positieve Invloed heeft op de hematologische status, waarbij de volgende belangrijke aspecten genoemd kunnen worden.

- Een homogenere verdeling van de celgrootte in het erythrocytaire en het thrombocytaire systeem.

- Een homogenere samenstelling van de neutrophiele granulocyten.

- Een verdwijnen van de grotere bloedplaatjes, welke als de meest actieve in het stollingsproces worden beschouwd.

- Een significante daling van de plaatjescriet als gevolg van training.

Resumerend kan men concluderen dat trainingsadaptie athankelijk is van individuele capaciteiten en individueel beoordeeld moet worden als het erom gaat overbelasting te vermijden. Dit blijkt te meer ult het feit dat de in dit onderzoek gebrulkte varlabelen niet voldoende discrimineren tussen groepen die meer of minder zijjn hersteld. 


\section{Curriculum vitae}

Gerard Maria Eugene Janssen werd op 13 november 1948 te Hulsberg geboren. Na het behalen van het diploma HBS-B in 1970 begon hij in datzelfde jaar met de studie scheikunde aan de Rijksuniversiteit te Utrecht. Het kandidaatsexamen $\left(\mathbf{S}_{3}\right)$ werd behaald in 1973 en het doctoraalexamen in december 1975.

Van 1976-1977 was hij docent aan de laboratoriumschool van het Van Leeuwen Instituut te Delft en van 1977 tot 1980 aan de middelbare scholen St. Michiel en Albert Schweitzer te Geleen. Daarnaast was hij van 1979 tot 1981, als wetenschappelijk ambtenaar, verbonden aan de Rijksuniversiteit Limburg, capaciteitsgroep Onderwijsontwikkeling en Onderwijsresearch en werkzaam in het deelproject Summatieve Evaluatie (Automatisering Itembank). Vanaf 1982 is hij in dienst van het instituut Sportgeneeskunde Limburg en gedetacheerd bij de vakgroep Humane Biologie, Faculteit der Gezondheidswetenschappen van de Rijksuniversiteit Limburg te Maastricht. 


\section{Dankwoord}

Het is heel verheugend een dankwoord te mogen schrijven, omdat je dat niet doet wanneer er geen reden voor is. De angst lemand te vergeten maakt het wel moellijk. Een vergeten werkafspraak kun je opnieuw maken, een vergeten uitnodiging of dankbetuiging kun je niet alsnog doen.

De omvang van dit project is zo groot dat de kans lemand te vergeten niet gering is. Zeer velen hadden op de een of andere manier hun bijdrage zowel in het marathon-project als bil het tot stand komen van deze dissertatie: vanaf het allereerste begin van het wilde idee tot en met de afsluiting van deze dag.

De bijdragen lagen op het gebied van de organisatie, practische uitvoering, medische begeleiding van de proefpersonen, wetenschappelijke inhoud, financieën en morele ondersteuning door vakgenoten: inspanning door mensen binnen en buiten de universiteit. Daarbij denk ik niet op de laatste plaats aan al die proefpersonen: zij hebben zich op een bewonderenswaardige wijze letterlijk uitgesloofd in dienst van de wetenschap!

- Promotor Foppe ten Hoor en Fré Bosman, Cees Degenaar, Ronald Does, Peter Frederik, Lucien Habets, Michel Janssen, Victor Kalser, Hans Keizer, Harm Kuipers, Paul Menheere, Frans Verstappen, Ger van der Vusse, Jan van Wersch en de beoordelingscommissie bestaande uit de voorzitter Harry Struyker Boudler, Karll Hamulyak, Han Kemper, Rob Reneman en Jan Vos voor de wetenschappelljke aspecten.

- De receptie van de universiteit, medewerkers van het Sportlaboratorium, het Laboratorium voor Anatomie, het Laboratorium voor Electronenmicroscopie, analisten van het Klinisch Chemisch Laboratorium (AZM), het Laboratorium voor Pathologie (AZM), medewerkers van het Rekencentrum en de Vakgroep Medische Informatica en Statistiek en van de Vakgroepen Medische Microbiologie en Fysiologie, anallsten van de afdellingen Hematologle en Bloedafmame in het De Wever Zlekenhuls te Heerlen, medewerkers van het Isotopenlaboratorium in datzelife zlekenhulis, artsen van het ISL die de keuringen uitvoerden, Marion de Vreede voor de verwerking van de vele aanmeldingen, Wilma Rusman voor de verleende loopschoen-adviezen en kortingen, Veronique America voor de enthousiaste en belangenloze medewerking, de talrijke veldhelpers van de Maandagavondgroep bi] de lange trainingslopen, atletlekvereningen Unitas, Achilles Top en Kimbria/AV'34 die ons In de gelegenheid stelden op hun accommodatie de trainingen af te werken, medewerkers van de afdelingen Algemene Heelkunde en Orthopedile (AZM) en fysiotherapeuten die snel de opgelopen blessures behandelden, Gerda Bruls en vele anderen die hielpen bij de tot standkoming van de definitieve tekst van dit proefschrift en..... de uiteindelljke reallsatie ervan.

- De proefpersonen 005 JR...121 CT...525 MK.

- Diegenen die ik nu toch nog vergeten ben.

Allen wil ik hartellik bedanken! 


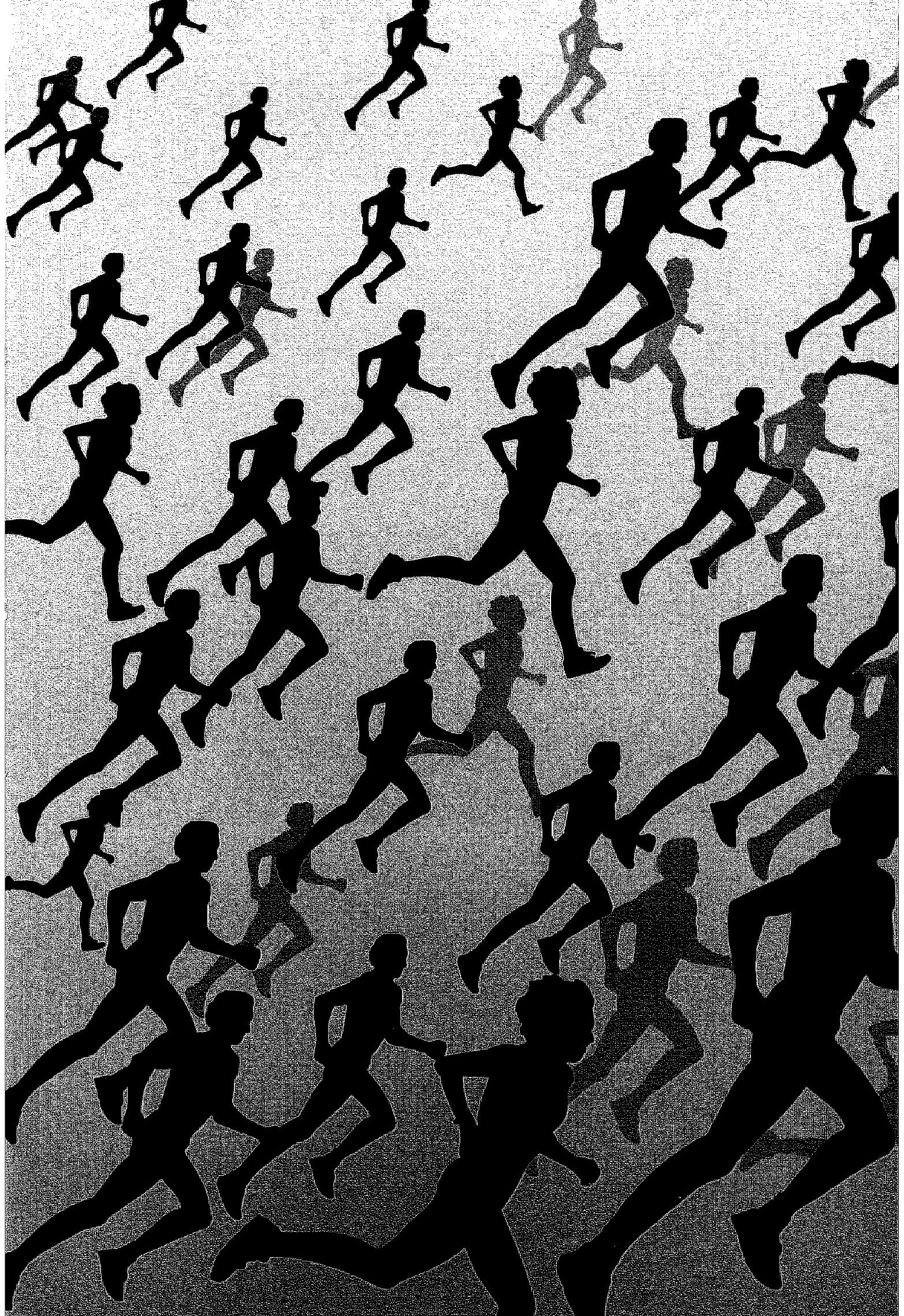

